Universidade de Brasília

Instituto de Geociências

\title{
GEOLOGIA, GEOCRONOLOGIA E GEOQUÍMICA DO EMBASAMENTO GRANÍTICO PALEOPROTEROZÓICO EM NATIVIDADE, FAIXA BRASÍLIA NORTE
}

DISSERTAÇÃO DE MESTRADO No 340

Isabela Moreno Cordeiro de Sousa 


\title{
GEOLOGIA, GEOCRONOLOGIA E GEOQUÍMICA DO EMBASAMENTO GRANÍTICO PALEOPROTEROZÓICO EM NATIVIDADE, FAIXA BRASÍLIA NORTE
}

\author{
Isabela Moreno Cordeiro de Sousa
}

Orientadora

Prof. ${ }^{a}$ Dra. Maria Emília Schutesky Della Giustina

Co-orientador

Claudinei Gouveia de Oliveira

Banca Examinadora

Prof. ${ }^{a}$ Dra. Maria Emília Schutesky Della Giustina Prof. Dr. Nilson Francisquini Botelho (UnB) Prof. Dr. Reinhardt Adolf Fuck (UnB)

Brasília

2015 
"Reality leaves a lot to the imagination" John Lennon 


\section{AgRADECIMENTOS}

Agradeço a todos que fizeram parte da minha caminhada. Agradeço aos meus pais por serem meu maior exemplo de sucesso. Agradeço ao meu irmão pelo carinho e agradeço ao Bernardo, por me fazer muito feliz.

Agradeço aos meus orientadores Maria Emília e Claudinei pela paciência e apoio.

Deixo meus agradecimentos também a todos os professores do Instituto de Geociências, por tudo que me ensinaram e por me inspirarem a sempre querer saber mais. 


\section{RESUMO}

O embasamento paleoproterozóico da Faixa Brasília corresponde ao terreno granítico exposto no segmento norte da faixa. Ele representa um arco desenvolvido na borda oeste do Cráton do São Francisco, ou um arco acrescionado ao cráton.

O embasamento é tradicionalmente dividido em dois domínios: Almas Conceição do Tocantins e Cavalcante-Arraias, nomeados em referência a cidades vizinhas. O primeiro é composto por tonalitos e granodioritos das suítes 1 e 2, intrusivos no Grupo Riachão do Ouro. No segundo, afloram granitos da suíte Aurumina, intrusivos na Formação Ticunzal.

A oeste do domínio Almas-Conceição do Tocantins aflora o embasamento Natividade, área estudada neste projeto. O embasamento Natividade é composto por associações geológicas semelhantes às dos outros dois domínios, mas pouco detalhada em pesquisas anteriores. Ele é dividido em suíte Rio do Moleque, suíte Manuel Alves, suíte Xobó e Granito Príncipe, intrusivos na sequência sedimentar Água Suja.

Rochas do embasamento foram submetidas a no mínimo dois eventos deformacionais: o primeiro no Paleoproterozóico e o segundo no fim Neoproterozóico. A orogenia paleoproterozóica atingiu fácies anfibolito, enquanto o evento Brasiliano, no Neoproterozóico, reequilibrou as paragêneses em fácies xisto verde.

Datações U-Pb no embasamento Natividade sugerem ao menos quatro estágios de magmatismo: o primeiro mais velho que $2.3 \mathrm{Ga}$, o segundo entre 2.20 e $2.30 \mathrm{Ga}$, o terceiro entre 2.16 e 2.18 Ga e o último entre 2.12 e $2.15 \mathrm{Ga}$.

Acredita-se que o primeiro, de idade sideriana, tenha formado o embasamento do arco que se desenvolveria no riaciano. Entretanto, não se sabe quais mecanismos foram responsáveis por sua geração. É possível que essas rochas tenham se formado em ambiente de arco magmático no fim do Arqueano e no início do Sideriano e retrabalhado a borda do Cráton do São Francisco.

No Riaciano, um arco magmático de caráter juvenil se instala, caracterizando o segundo episódio magmático. O terceiro estágio é uma progressão do segundo e exibe magmas ligeiramente mais evoluídos.

O quarto estágio de magmatismo ilustra a colisão de uma massa continental com o cráton. A colisão provocou fusão parcial da crosta e gerou granitos com características de granitos tipo $\mathrm{S}$. 
As suítes 1 e 2 do domínio Almas-Conceição do Tocantins e as suites Rio do Moleque e Manuel Alves do embasamento Natividade caracterizam o magmatismo de arco, evoluindo em um trend calcialcalino.

A suíte Aurumina, no domínio Cavalcante-Arraias, a suíte Xobó e o Granito Príncipe são os granitos sincolisionais, gerados por retrabalhamento crustal. Dados de Sm-Nd confirmam o caráter de fusão crustal desses granitos.

Assim, domínios dentro do embasamento indicam áreas com predominância de rochas com assinatura de arco ou rochas de retrabalhamento crustal e não configuram blocos tectônicos distintos. É possível que as sequências vulcano-sedimentares - Grupo Riachão do Ouro, Formação Ticunzal e Sequência Água Suja - sejam contemporâneas e tenham pertencido à mesma bacia sedimentar.

Desde o Riaciano, as rochas desenvolvidas nessa orogenia paleoproterozóica são parte do Cráton do São Francisco e constituem o embasamento sobre o qual sedimentos da Faixa Brasília foram depositados.

Palavras-chave: Paleoproterozóico, Riaciano, Embasamento, Faixa Brasília, Natividade 


\section{ABSTRACT}

Brasília Belt's basement is the Paleoproterozoic granitic terrane exposed in the northern segment of the belt. It represents a magmatic arc developed on the western margin of São Francisco craton, or acreeted to it during Rhyacian.

Basement is traditionally divided in two domains: Almas-Conceição do Tocantins and Cavalcante-Arraias, named after neighbouring cities. The former encompasses tonalites and granodiorites from Suites 1 and 2, intrusive in Riachão do Ouro Group; the latter is composed of granites from Aurumina suite, intrusive in Ticunzal Formation.

West of Almas-Conceição do Tocantins crops out Natividade basement, the area detailed in this study. Natividade basement is composed of similar geologic units, but not detailed in previous researches. It is devided in Rio do Moleque suite, Manuel Alves suite, Xobó suite and Príncipe Granite. Magmatic suites are intrusive in Água Suja volcanosedimentary sequence.

Basement rocks underwent at least two deformational events, one during Paleoproterozoic, and the second during late Neoproterozoic. Paleoproterozoic event achieved amphibolite facies and Brasiliano Neoproterozoic event reequilibrated parageneses to greenschist facies.

$\mathrm{U}-\mathrm{Pb}$ analyses in zircon grains of granitic rocks from Natividade basement suggest there are at least four stages of magmatism: The first, older than $2.3 \mathrm{Ga}$; the second between 2.20 and $2.30 \mathrm{Ga}$, the third between 2.16 and $2.18 \mathrm{Ga}$ and the last one between 2.12 and 2.15 $\mathrm{Ga}$.

The first stage, of Siderian age, is believed to have formed the Rhyacian arc's basement, but it is unknown which mechanisms were responsible for it. It possibly developed in a late-Archean/Siderian magmatic arc on São Francisco craton margin.

During Rhyacian, a magmatic arc begins to develop, generating the second stage of magmatism. The third stage is an evolution of the second, both in the same arc system.

Fourth stage represents the arc collision against São Francisco craton, or collision of another landmass, if we consider the arc evolving in the craton's border. The collision triggered crustal melting and generated granites with S-type signature.

Suites 1 and 2 from Almas-Conceição do Tocantins domain, Rio do Moleque and Manuel Alves suites from Natividade basement characterize the arc magmatism, evolving in a calc-alkaline trend. 
Aurumina suite, in Cavalcante-Arraias domain, Xobó suite and Príncipe Granite, in Natividade basement, show a syn-collisional signature, resulted from crustal reworking. Sm$\mathrm{Nd}$ data confirm crustal melting character of these bodies.

Thus, domains within the basement represent predominance of rocks with volcanic-arc or with syn-collisional signature, and do not configure different tectonic blocks. It is possible that volcano-sedimentary sequences of the whole basement - Riachão do Ouro Group, Ticunzal Formation and Água Suja sequence - were coeval and belonged to the same basin.

Since Rhyacian, rocks developed in this Paleoproterozoic orogeny are part of the São Francisco Paleoplate and constitute the basement over which sediments from Brasília Belt were deposited.

Key-words: Paleoproterozoic, Rhyacian, Basement, Brasília Belt, Natividade 


\section{SUMÁRIO}

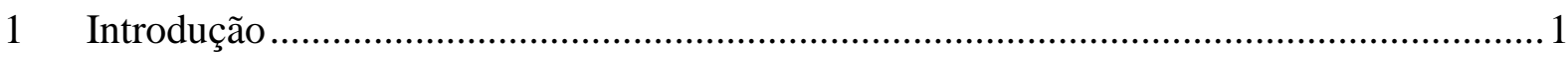

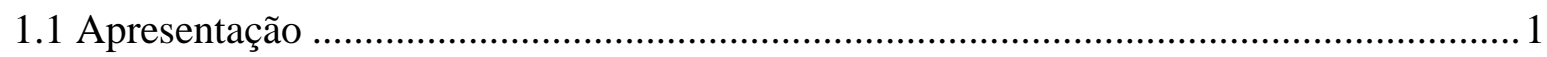

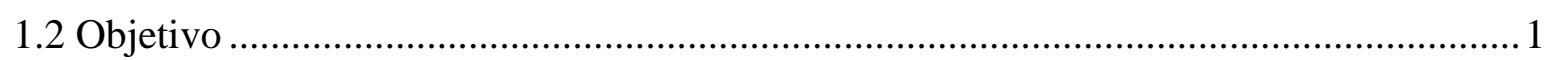

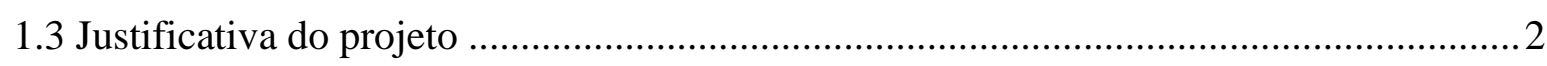

1.4 Localização da área de estudo ....................................................................................

1.5 Trabalhos de campo e métodos analíticos .................................................................

1.5.1 Lâminas delgadas .......................................................................................

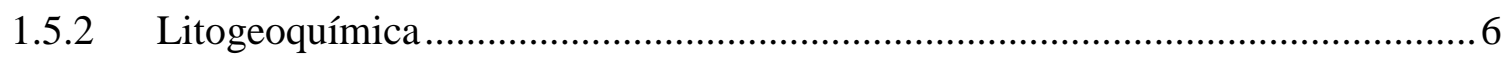

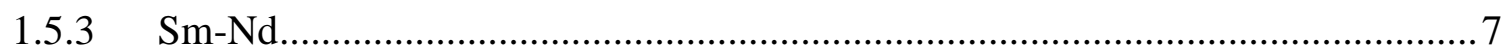

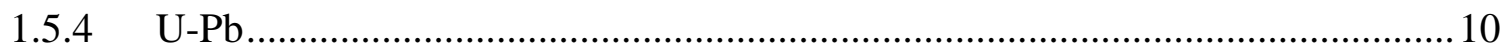

1.5.5 Química Mineral - Microssonda Eletrônica (MSE) ................................................... 12

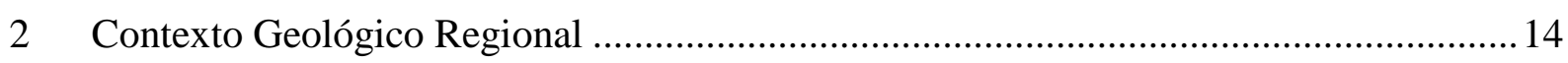

2.1 A Faixa Brasília: síntese sobre seus elementos e evolução …………………………….... 14

2.1.1 Embasamento granítico paleoproterozóico ………………………………………..... 16

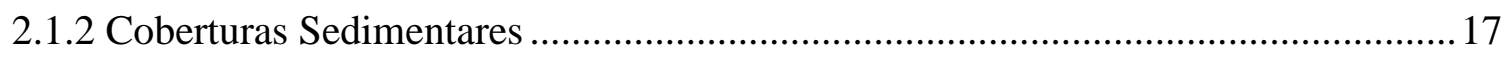

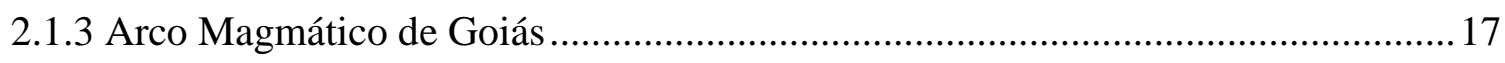

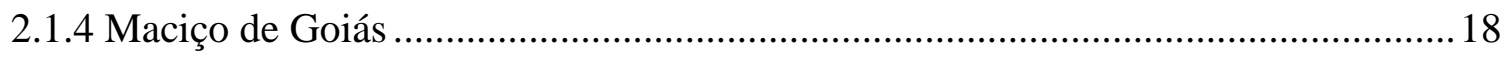

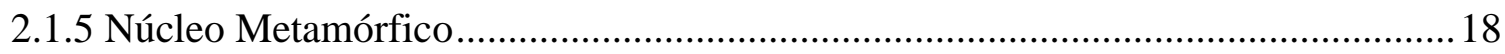

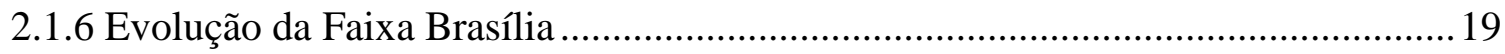

2.2 Características dos terrenos paleoproterozóicos da Faixa Brasília..................................20

2.2.1 Embasamento Paleoproterozóico na Faixa Brasília Norte ........................................20

2.2.2 Sequência Campinorte ………………………………………………………...2 23

2.2.3 Greenstone belts do Maciço de Goiás .........................................................................2

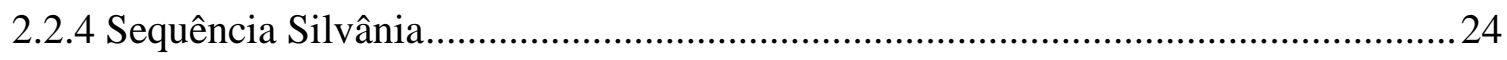

2.3 Características do Paleoproterozóico a oeste do Arco Magmático de Goiás ..................24 
3 The Natividade basement: petrography and mineral chemistry of Paleoproterozoic

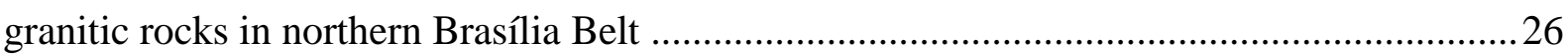

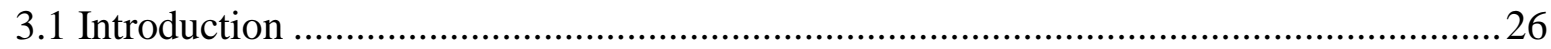

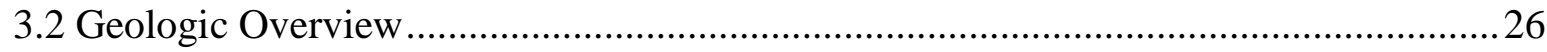

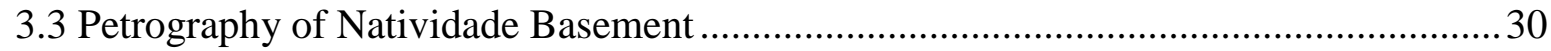

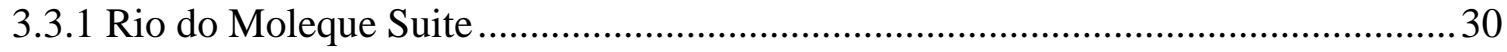

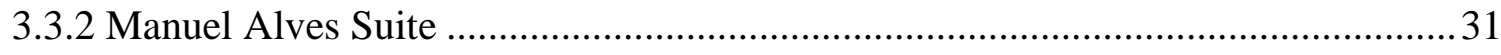

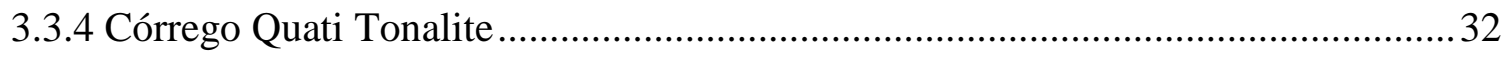

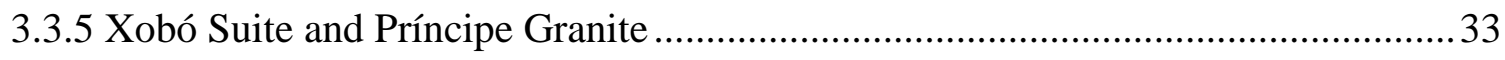

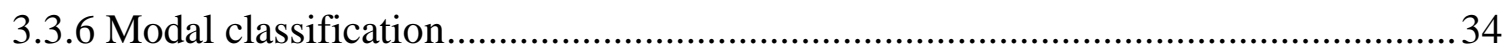

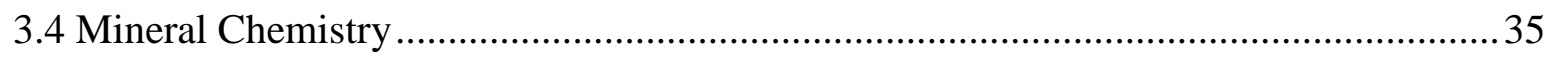

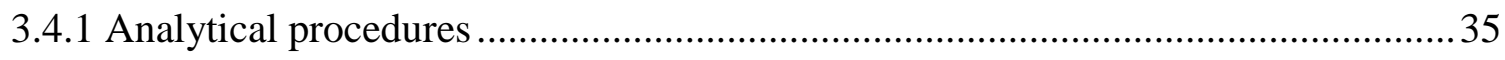

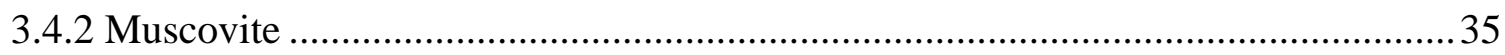

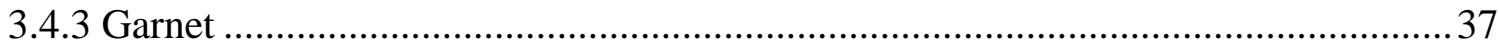

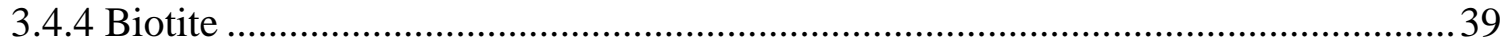

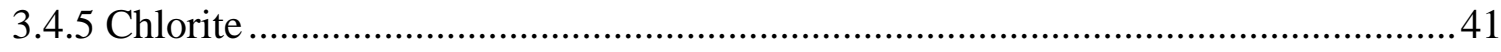

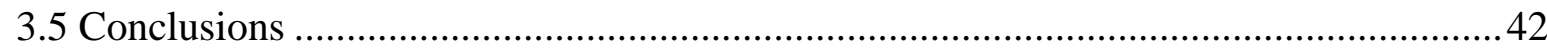

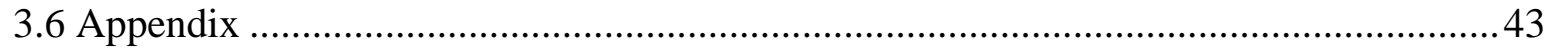

4 Rhyacian crustal evolution of northern Brasília Belt basement: constraints from

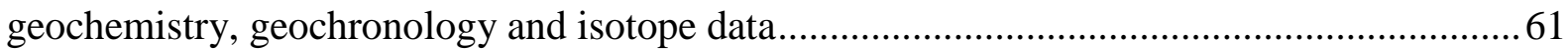

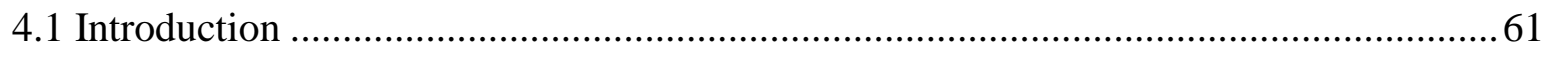

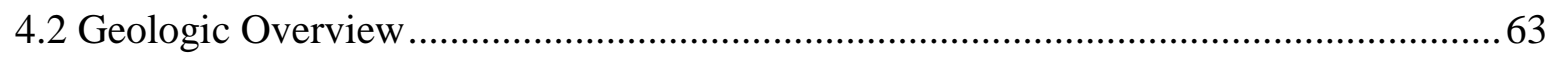

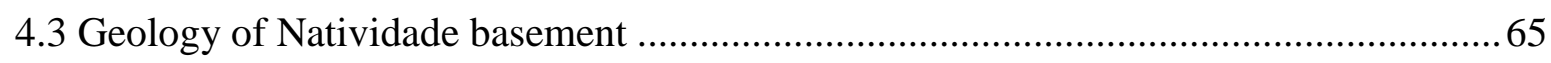

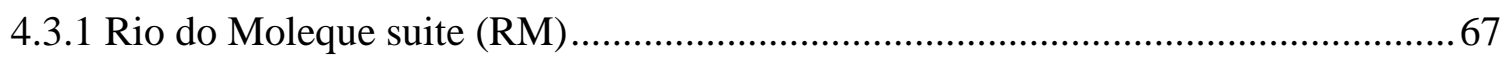

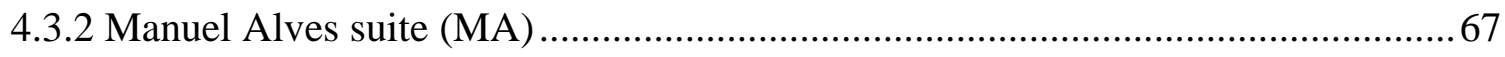

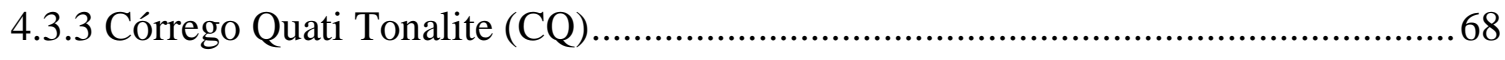

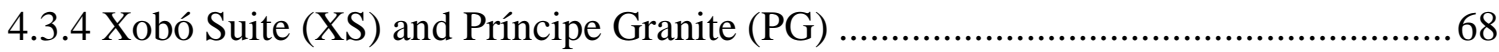




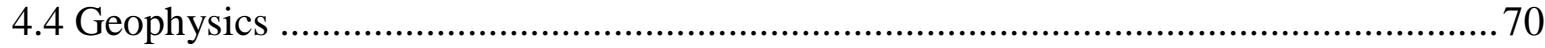

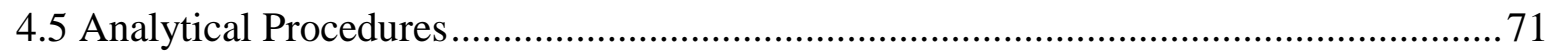

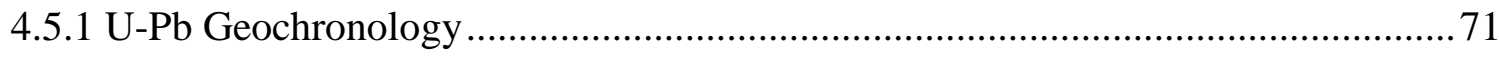

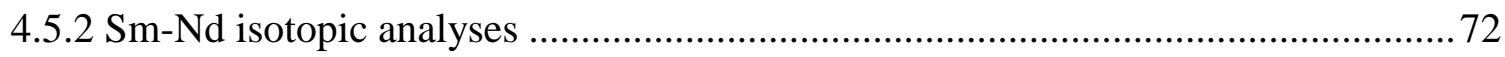

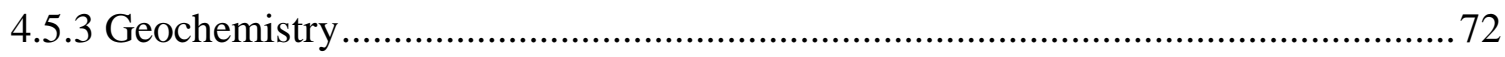

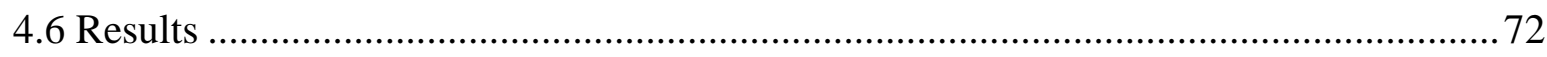

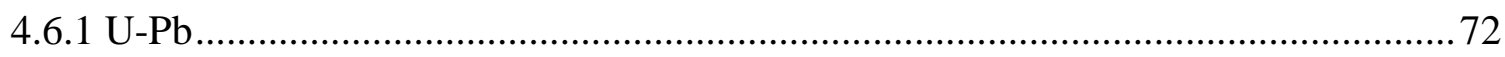

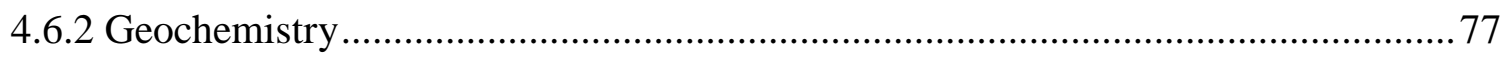

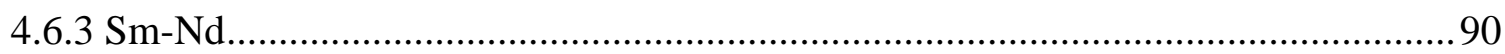

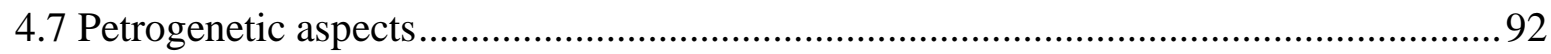

4.8 Tectonic setting and proposed evolutional model ...................................................96

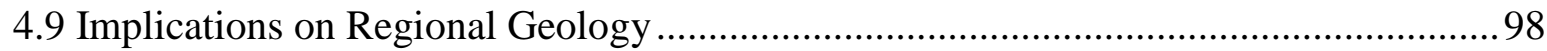

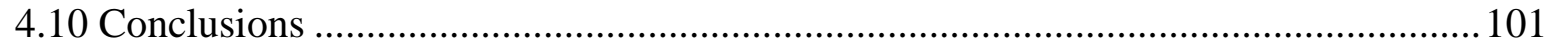

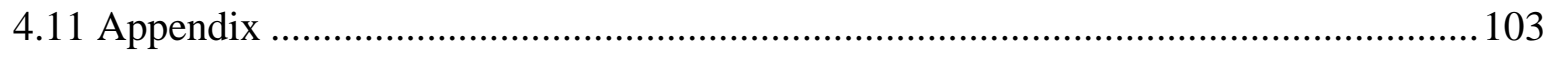

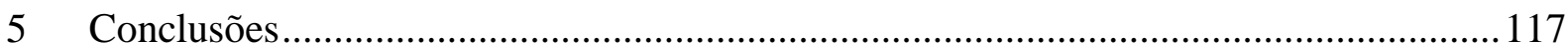

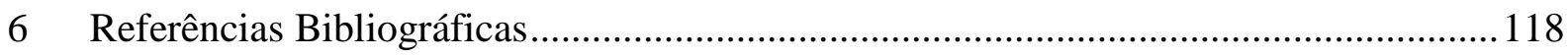

\section{ÍNDICE DE FIGURAS}

Figura 1.1: Mapa esquemático da Faixa Brasília (Modificado de Pimentel et al., 2006;

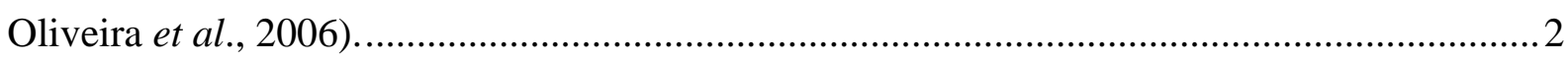

Figura 1.2: Mapa de vias de acesso à Natividade - TO. Área em vermelho na figura 1.3.......4 Figura 1.3: Área do projeto de mestrado e localização das cidades de Natividade, Chapada da Natividade e dos povoados de Bonfim e Príncipe............................................................... 5

Figura 1.4: Efeito da fusão parcial do manto na evolução isotópica de Nd na crosta continental e no manto residual (depletado). Assume-se que o manto não depletado tem a mesma razão Sm/Nd do CHUR (Modificado de Faure \& Mensing, 2005). ..................................................

Figura 2.1: Província Tocantins (Almeida et al., 1981) ........................................................ 15 
Figura 2.2: Mapa esquemático da Faixa Brasília. Áreas circuladas em vermelho são terrenos de idade paleoproterozóica (Modificado de Pimentel et al., 2006; Oliveira et al., 2006)........ 15 Figura 2.3: Domínios do embasamento da Faixa Brasília Norte (Modificado de Pimentel et al., 2006).

Figure 3.1: Domains in Northern Brasília Belt. Almas-Conceição do Tocantins, CavalcanteArrais domains and Natividade Basement (Modified after Pimentel et al., 2006; Oliveira et al., 2006). 27

Figure 3.2: Geologic map from Natividade Basement (Oliveira, 2012). 29 Figure 3.3: Photomicrography from tonalite sample NI-VIII-122 (RM suite). A) Recrystallyzed quartz, saussuritized plagioclase and neoformed epidote; B) Muscovite lamellae believed to be a magmatic phase; C and D) Neoformed grains of allanite and epidote. Greenish-brown biotite. (Qzt: quartz; Pl: plagioclase; Ep: epidote; Ms: muscovite; Bt: biotite; All: allanite). 30

Figure 3.4: Photomicrography from tonalite sample NI-V-95 (:MA suite): A) Oriented biotite lamellae, recrystallized quartz and saussuritized plagioclase; B) Sericite formation in cleavage planes from plagioclase; C) Neoformed clinozoizite grains; D) Photomicrography from tonalite sample NI-V-90 (MA suite). Anhedral garnet grain. (Qzt: quartz; Pl: plagioclase; Czz: clinozoizite; Bt: biotite; Grt: garnet).

Figure 3.5: Photomicrography from tonalite sample NI-VII-38 (CQ tonalite): A) general texture of samples from CQ tonalite; B) Euhedral garnet grain. (Qzt: quartz; Bt: biotite; Grt: garnet; Chl: chlorite).

Figure 3.6: Photomicrography from granite sample NI-X-104 (Príncipe Granite). A and B)Muscovite grain of magmatic composition (Corrêa, 2014), recrystallized quartz, small euhedric plagiocase grain and large microcline grain. (Qzt: quartz; Pl: plagioclase; Ms: muscovite; Kf: microcline).

Figure 3.7: A) Photomicrography from granite sample NI-I-50 (Xobó suite). Muscovite is comparable in size to plagioclase grains and is considered primary. Plagioclase grains are well preserved and quartz is recrystallized; B) Photomicrography from granite sample 1.1 (Xobó suite). This rock crops out close to a shear zone. Quartz is completely recrystallized and large muscovite is neoformed (as shown in the next topic), but smaller grains are believed to be magmatic. 34

Figure 3.8: QAP diagram (Streckeisen, 1976) of Natividade Basement. 34 
Figure 3.9: Compositions of analysed muscovite grains in terms of $\mathrm{Ti}, \mathrm{Mg}$ and $\mathrm{Na}$. The dashed line is the approximate division of primary and secondary mica domains after Miller $e t$ al., 1981.

Figure 3.10: a. $\mathrm{K}_{2} \mathrm{O}$ vs $\mathrm{Al}_{2} \mathrm{O}_{3}$ for muscovite. Note Xobó Suite has muscovite grains with low

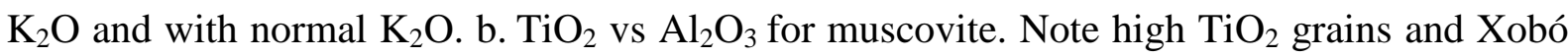
suite's low $\mathrm{TiO}_{2}$ grains. 36

Figure 3.11: Garnet composition in terms of $\mathrm{Mg}, \mathrm{Mn}$ and $\mathrm{Fe}$ (atomic proportions). Grey area corresponds to magmatic garnet field delimited by Miller \& Stoddard (1981).

Figure 3.12: Garnet composition in terms of $\mathrm{Fe}, \mathrm{Al}-(2 \mathrm{Ca}+\mathrm{Na}+\mathrm{K})$ and $\mathrm{Mn}$ (atomic proportions). Rectangular area corresponds to composition of garnet described as magmatic by Miller \& Stoddard (1981). 38

Figure 3.13: A) $\mathrm{SiO}_{2}$ vs $\mathrm{MnO}$; B) $\mathrm{SiO}_{2}$ vs $\mathrm{Mn} / \mathrm{Fe}+\mathrm{Mg}$. CQ tonalite comprises garnet grains with the highest $\mathrm{MnO}$ content. 39

Figure 3.14: Biotite classification after Nachit et al., 2005. A: Domain of primary magmatic biotite. B: Domain of reequilibrated biotite. C: Domain of neoformed biotite.

Figure 3.15: Biotite composition of XS, CQ, Ma and RM. $\mathrm{SiO}_{2}$ vs $\mathrm{TiO}_{2}$ and $\mathrm{SiO}_{2}$ vs $\mathrm{MnO}$. Colours represent biotite analysis in grains from the same sample.

Figure 3.16: Biotite composition of XS, CQ, Ma and RM. $\mathrm{SiO}_{2}$ vs $\mathrm{Al}_{2} \mathrm{O}_{3}$ and $\mathrm{SiO}_{2}$ vs $\mathrm{Mg} / \mathrm{Fe}$. Colours represent biotite analysis in grains from the same sample. 41

Figure 3.17: Chlorite composition of $\mathrm{CQ}$ and $\mathrm{MA}$. $\mathrm{SiO}_{2}$ vs $\mathrm{FeO}$ and $\mathrm{SiO} 2$ vs $\mathrm{MnO}$ 42

Figure 4.1:Tocantins Province (Almeida et al., 1981) 62

Figure 4.2: Brasília Belt schematic map (Modified from Pimentel et al., 2006; Oliveira et al., 2006)

Figure 4.3: Domains within Northern Brasília Belt. Almas-Conceição do Tocantins, Cavalcante-Arrais domains and Natividade basement (Modified from Pimentel et al., 2006; Oliveira, 2006). 64

Figure 4.4: Geologic map of Natividade basement and Almas Conceição do Tocantins domain (Modified from Costa et al., 1976; Cruz, 1993 and Oliveira et al., 2012). Suite 1 and Suite 2 were defined by Cruz (1993). Suite 2 on the wastern limit of Almas-Conceição do Tocantins mapped by Cruz (1993) coincides with Rio do Moleque suite mapped by Oliveira, 2012......66 Figure 4.5: Main geologic units in Brasília Belt's basement. 68 Figure 4.6: QAP diagram (Streckeisen, 1976) Plotted samples are from Natividade basement, Almas Conceição do Tocantins and Cavalcante-Arraias domains. 69 
Figure 4.7: ASA image (CPRM, 2006). CASZ: Cruz das Almas Shear Zone. Rectangles delimit Natividade Basement and Almas-Conceição do Tocantins domains.

Figure 4.8: False colour composition. Gammaspectometry image (CPRM, 2006). CASZ:Cruz das Almas Shear Zone. Rectangles delimit Natividade Basement and Almas-Conceição do Tocantins domains.

Figure 4.9: Sample G3 is the oldest rock found in Natividade basement. It crops out within RM suite, but is probably its basement or a xenolith. Sample PI41 represents the true age of RM suite.

Figure 4.10: Sample NI-VIII-122 is similar to PI41, both from RM suite. NI-V-24 tcropsou within CQ tonalite, but it is older than it. CQ tonalite is probably intrusive in rocks of RM age .74

Figure 4.11: Sample NI-V-95 is from MA suite. Sample G7 is from CQ tonalite. .74

Figure 4.12: Discordia ages for both porphyritic and fine-grained facies from Príncipe Granite. .74

Figure 4.13: Discordia ages in Xobó suite. 75

Figure 4.14:. Natividade basement and Almas Conceição do Tocantins domain showing distribution of new geochronological and geochemical data (Modified from Costa et al., 1976; Cruz, 1993 and Oliveira, 2012). .76

Figure 4.15: Total Alkali-Silica diagram (Le Bas et al., 1986)............................................ 81

Figure 4.16: $\mathrm{SiO}_{2}$ vs $\mathrm{K}_{2} \mathrm{O}$ diagram (Peccerillo and Taylor, 1976)....................................... 82

Figure 4.17: AFM (Irvine \& Baragar, 1971) and Felspar triangle (O'Connor, 1965). ........... 82

Figure 4.18: Aluminum Saturation Index (Shand, 1943) and $\mathrm{SiO}_{2}$ vs ASI............................. 83

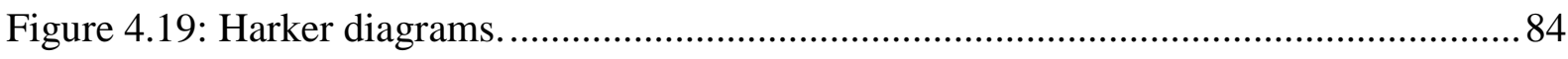

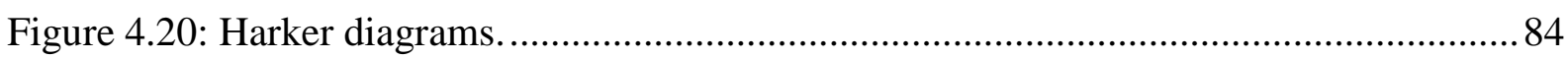

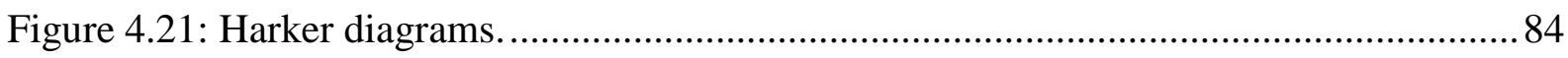

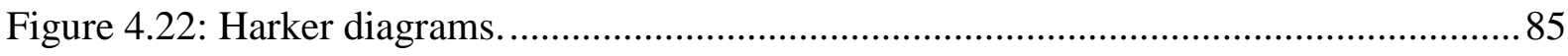

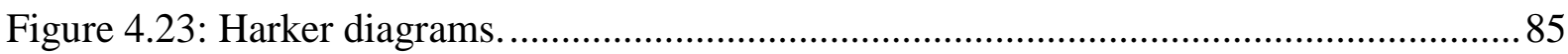

Figure 4.24: $\mathrm{K}_{2} \mathrm{O}$ vs $\mathrm{Na}_{2} \mathrm{O}$ and $\mathrm{FeO}$ (total) vs $\mathrm{CaO}$ (Chappell \& White, 1974)......................86

Figure 4.25: REE and multielementar spidergram of RM suite (Sun \& McDonough, 1989).. 86 Figure 4.26: REE and multielementar spidergram of MA suite (Sun \& McDonough, 1989).. 87 Figure 4.27: REE and multielementar spidergram of CQ tonalite (Sun \& McDonough, 1989). 
Figure 4.28: REE and Multielementar spidergrams of XS and PG (Sun \& McDonough, 1989).

Figure 4.29: REE spidergram of S1 and S2 (Sun \& McDonough, 1989), data from Cruz (1993). 88

Figure 4.30: Multielementar and REE spidergrams for Aurumina suite (Sun \& McDonough, 1989). 89

Figure 4.31: Tectonic discrimination diagrams (Pearce et al., 1984) 90

Figure 4.32: Nd isotopic evolution diagram of Natividade basement. One representative sample of each unit is presented.

Figure 4.33: Nd evolution diagram comparing isotopic compositions of Natividade basement.

Figure 4.34: Cationic Na-K-Ca diagram (Nockolds \& Allen, 1953)

Figure 4.35: Proposed tectonic evolution of Brasília Belt basement. 97

Figure 4.36: Schematic representation of Paleoproterozoic rocks distribution in Brasília Belt basement. >2.3 area is the Ribeirão das Areias Complex. 98 Figure 4.37: Campinorte sequence outcrop in Brasília Belt (Modified from Pimentel et al., 2006; Oliveira et al., 2006).

Figure 4.38: Chemistry data from Campinorte sequence (Cordeiro, 2014). A) SiO2 versus $\mathrm{K} 2 \mathrm{O}+\mathrm{Na} 2 \mathrm{O}-\mathrm{CaO}$ plot from Frost et al. (2001); B) Rb versus $\mathrm{Y}+\mathrm{Nb}$ plot of Pearce et al. (1984); C) R1-R2 cationic plot of Batchelor and Bowden (1985); D) A/NK versus A/CKN (Shand diagram) plot. 100

Figure 4.39: $\mathrm{Nd}$ isotopic evolution diagram comparing isotopic compositions of the Campinorte sequence and related intrusive rocks. Compositional fields of the Mara Rosa Magmatic Arc (Junges et al., 2003) and Goiás Archean Gneisses (Pimentel et al., 1996) are also shown (Della Giustina, 2007). 


\section{ÍNDICE DE TABELAS}

Tabela 1.1: Limite de detecção dos elementos analisandos na geoquímica de rocha total. .......7

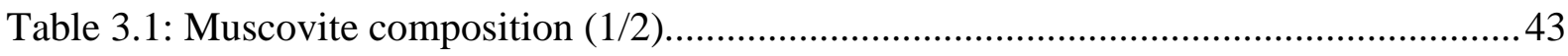

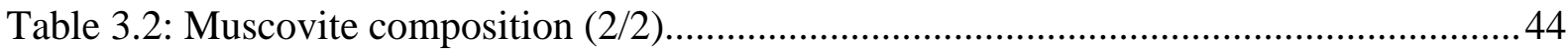

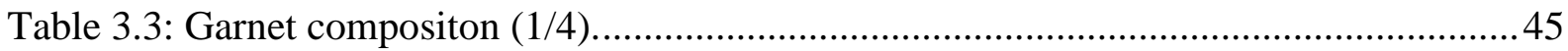

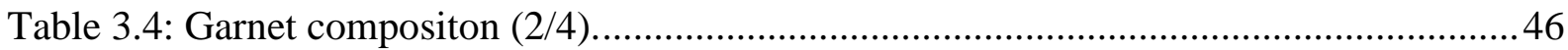

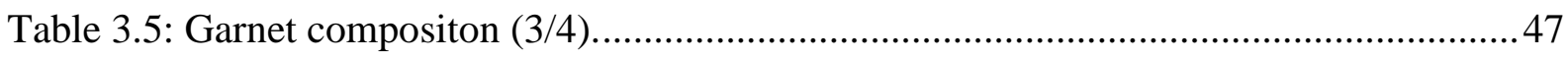

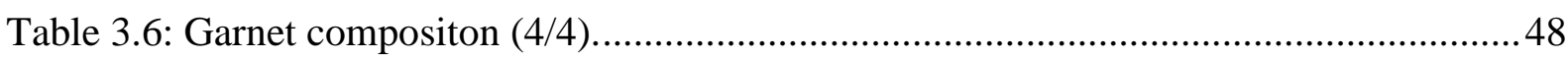

Table 3.7: Garnet end-member based on 12 oxygens. $\mathrm{Fe}^{2+} / \mathrm{Fe}^{3+}$ calculated assuming full site

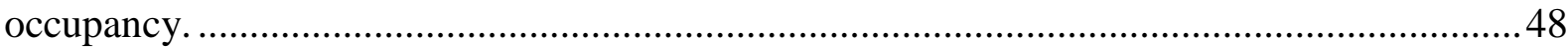

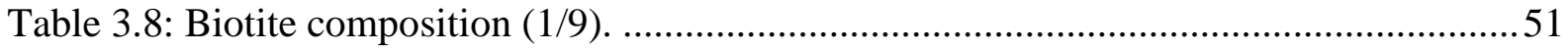

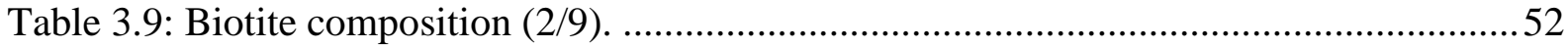

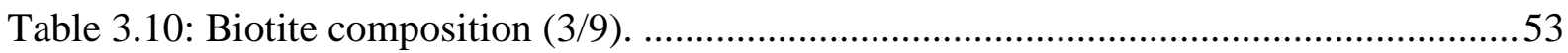

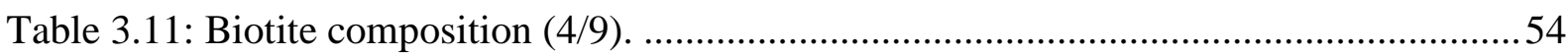

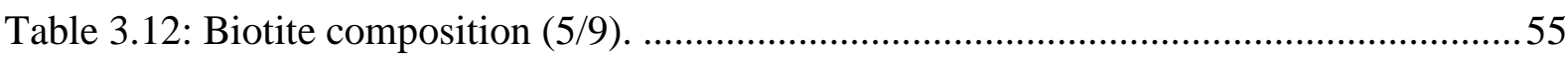

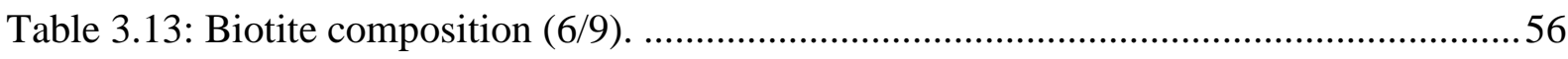

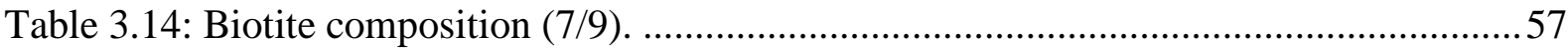

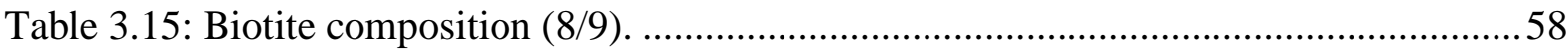

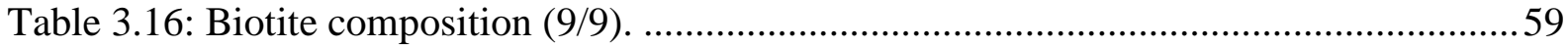

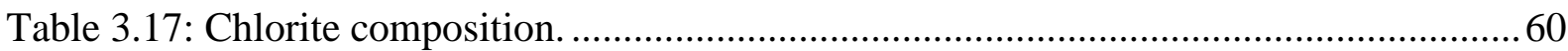

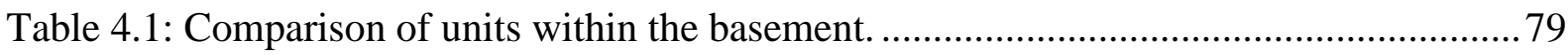

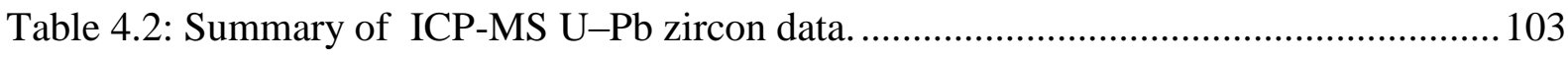

Table 4.3: Whole rock chemistry results from Natividade basement (1/4) .......................... 111

Table 4.4: Whole rock chemistry results from Natividade basement (2/4).......................... 112

Table 4.5: Whole rock chemistry results from Natividade basement (3/4).......................... 113

Table 4.6: Whole rock chemistry results from Natividade basement (4/4).......................... 114

Table 4.7: Sm-Nd isotopic data for Natividade basement. .................................................. 115

Table 4.8: Coordinates from samples used in this project................................................ 116 


\section{INTRODUÇÃo}

\subsection{Apresentação}

A ideia deste projeto de mestrado surgiu quando, ao fim do Trabalho Final de Graduação do ano de 2012 (TF-2012), ainda restavam muitas dúvidas acerca da evolução geológica da região estudada.

Os integrantes do TF-2012 cartografaram uma área de aproximadamente $1440 \mathrm{~km}^{2}$ que engloba as cidades de Natividade, Chapada da Natividade e os povoados de Bonfim e Príncipe, no estado do Tocantins, dentro do domínio da Faixa Brasília Setentrional.

O mapeamento realizado pela equipe do TF-2012 se soma a trabalhos anteriores e, em suma, três unidades geológicas principais são reconhecidas:

(i) uma sequência de rochas vulcânicas e sedimentares descrita na literatura por Sequência Água Suja (Queiroz, 2001) e por Grupo Riachão do Ouro (Costa, 1985);

(ii) um conjunto de rochas graníticas intrusivas na sequência vulcano-sedimentar;

(iii) uma espessa sequência sedimentar, possivelmente mesoproterozóica, denominada Grupo Natividade (Costa et al., 1976) que recobre as outras duas unidades.

A região já foi alvo de pesquisas anteriores em virtude da existência de inúmeras mineralizações auríferas que ocorrem hospedadas ora na sequência vulcano-sedimentar, ora nas rochas graníticas.

O conjunto formado pela sequência vulcano-sedimentar e pelas rochas graníticas é interpretado como o embasamento paleoproterozóico da Faixa Brasília. Entretanto, pouco se sabe sobre a natureza e a idade do magmatismo granítico que formou esse terreno e como essas rochas evoluíram no tempo geológico.

Nesse sentido, a presente dissertação de mestrado foi idealizada para dar continuidade ao projeto de pesquisa do TF-2012 e investigar uma área dentro desse embasamento granítico (Figura 1.1).

\subsection{Objetivo}

O objetivo deste projeto é datar as rochas graníticas que afloram nas proximidades de Natividade e analisá-las química e petrograficamente, de modo a obter dados que permitam inferir sobre a evolução geológica da região. 


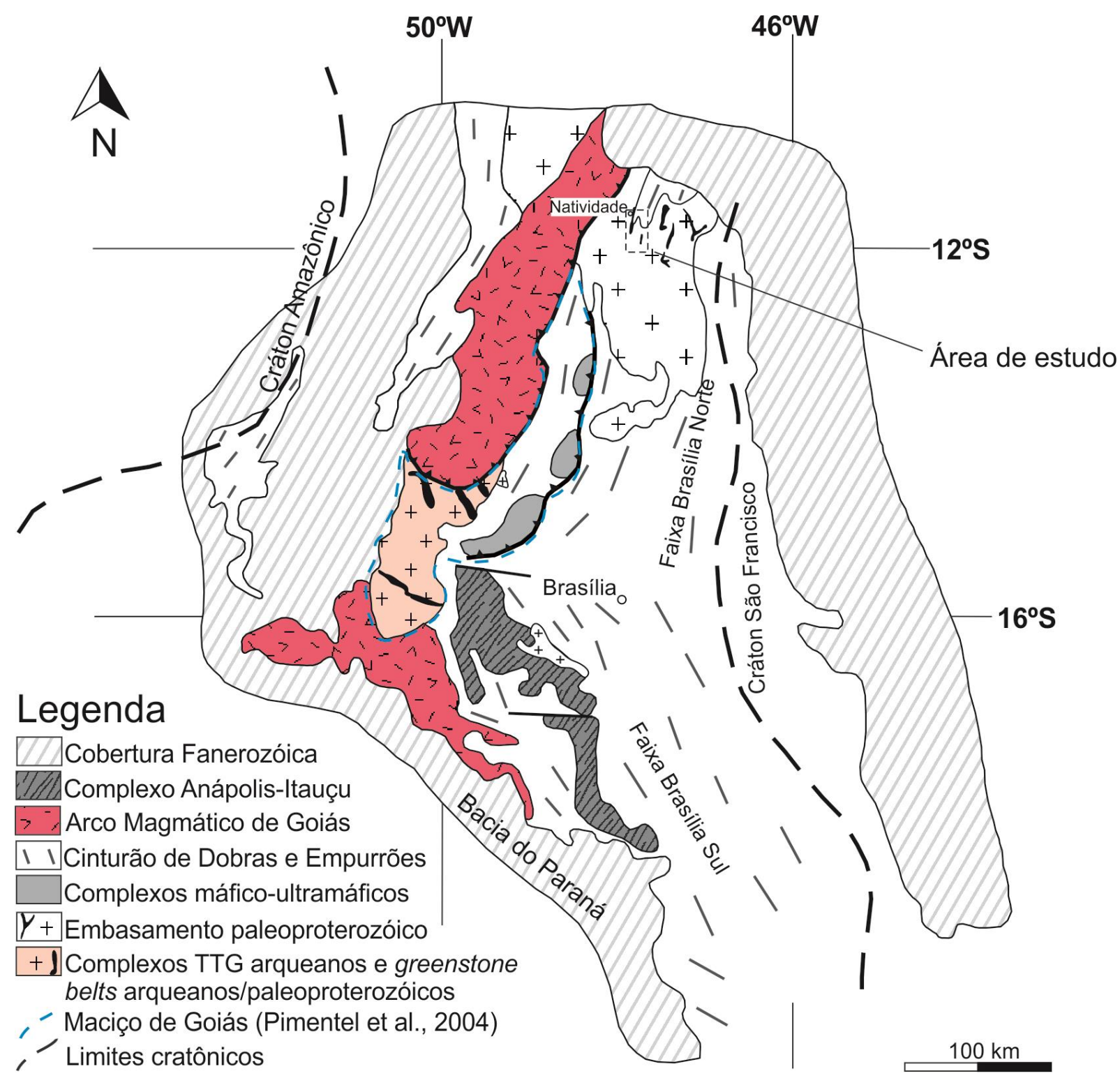

Figura 1.1: Mapa esquemático da Faixa Brasília (Modificado de Pimentel et al., 2006; Oliveira et al., 2006).

\subsection{Justificativa do projeto}

Trabalhos pioneiros na Faixa Brasília datam da década de 60, e desde então, o avanço no conhecimento geológico é possível devido aos projetos de pesquisa desenvolvidos na região.

Cruz \& Kuyumjian (1998, 1999), Cruz et al. (2003), Kuyumjian et al., (2012), Gorayeb (1988) e Costa (1985) são os principais responsáveis pelos projetos desenvolvidos no embasamento do extremo norte da faixa. Seus trabalhos são importantes não só pela caracterização geológica, mas também por apresentarem as primeiras datações feitas na região. 
A área de afloramento do embasamento paleoproterozóico é muito extensa e cada trabalho citado se dedicou ao estudo de uma porção. Este projeto de mestrado não é diferente, e foca uma área ainda pouco pesquisada.

O estudo de terrenos paleoproterozóicos é especialmente interessante porque idades em torno de $2.1 \mathrm{Ga}$, já encontradas em rochas do embasamento da Faixa Brasília, podem estar relacionadas a um processo orogenético de escala mundial que culminou com a formação do supercontinente Columbia (Rogers \& Santosh, 2002; Zhao et al., 2002, 2004).

Importantes mineralizações auríferas estão relacionadas a episódios de geração de crosta no Paleoproterozóico, hospedadas nas faixas greenstone ou em rochas graníticas submetidas a processos hidrotermais durante a orogênese. A Faixa Ashanti no cráton Oeste Africano e depósitos no orógeno Trans-Hudsoniano no Canadá são exemplos de mineralizações desenvolvidas nesse contexto.

Assim, este estudo é importante tanto pelo potencial metalogenético de orógenos paleoproterozóicos, quanto para o entendimento do ciclo global de geração de um supercontinente paleo-mesoproterozóico.

\subsection{Localização da área de estudo}

A coleta de amostras para estudo ocorreu no sudeste do estado do Tocantins, em uma área que envolve as cidades de Natividade, sede dos trabalhos de campo, e Chapada da Natividade.

Natividade é a maior entre as duas cidades, possui 9000 habitantes e surgiu como um povoado de garimpeiros no fim do século XVIII. Atualmente ainda existem diversos garimpos em atividade e seu centro histórico é tombado pelo Instituto do Patrimônio Histórico e Artístico Nacional.

O acesso a Natividade, por via rodoviária, pode ser feito através dos seguintes principais trajetos a partir de Brasília (Figura 1.2):

- Seguir pela rodovia BR-080 até a BR-153. Seguir pela BR-153 até Alvorada-TO e então acessar a TO-373. Seguir pela rodovia TO-373 até chegar a um pequeno trecho da TO-242 que dá acesso à TO-280. Continuar na TO-280 até chegar a Natividade. Esse trajeto passa pelas cidades de Padre Bernardo, Barro Alto, Uruaçu, Campinorte, Santa Tereza de Goiás e Porangatu, em Goiás, e por Talismã, Alvorada e São Valério da Natividade, no Tocantins. 
- Seguir pela rodovia BR-010, que é coincidente com a GO-118 até a cidade de Teresina de Goiás. A partir de Teresina de Goiás, a BR-010 ainda está em processo de implantação, e deve-se seguir pela GO-118 até chegar ao estado do Tocantins, onde ela passa a se chamar TO-050. No povoado de Príncipe, a TO-50 encontra a BR-010, que volta a ser pavimentada, e deve-se seguir pela BR-010 até Natividade. Esse trajeto passa pelas cidades de São João d'Aliança, Alto Paraíso de Goiás, Teresina de Goiás, Monte Alegre de Goiás e Campos Belos, em Goiás, e por Arraias e Conceição do Tocantins, no Tocantins.

Ambos os trajetos descritos são em rodovias pavimentadas. $\mathrm{O}$ primeiro tem cerca de $740 \mathrm{~km}$ e o segundo, cerca de $650 \mathrm{~km}$.

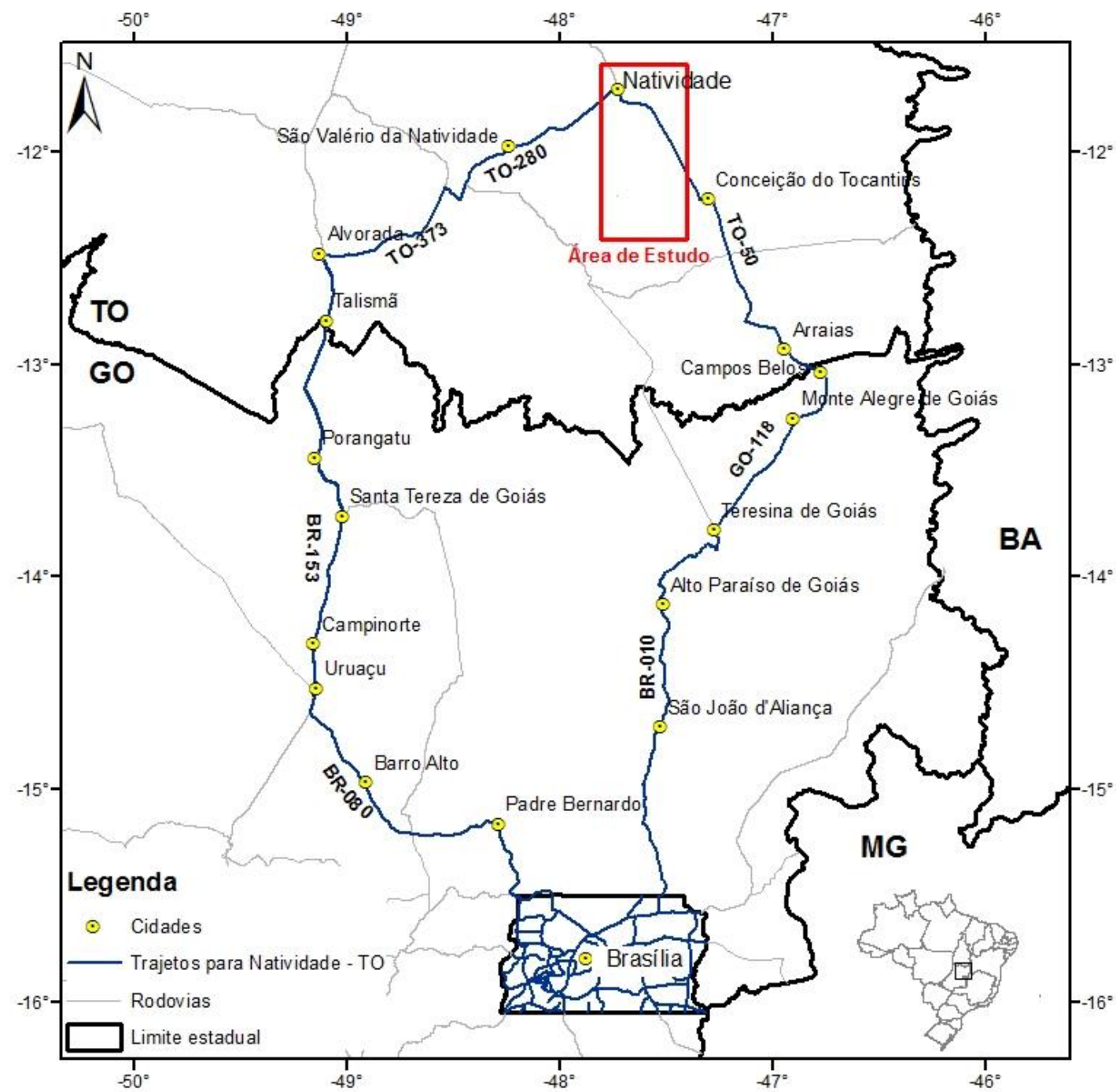

Figura 1.2: Mapa de vias de acesso à Natividade - TO. Área em vermelho na figura 1.3. 


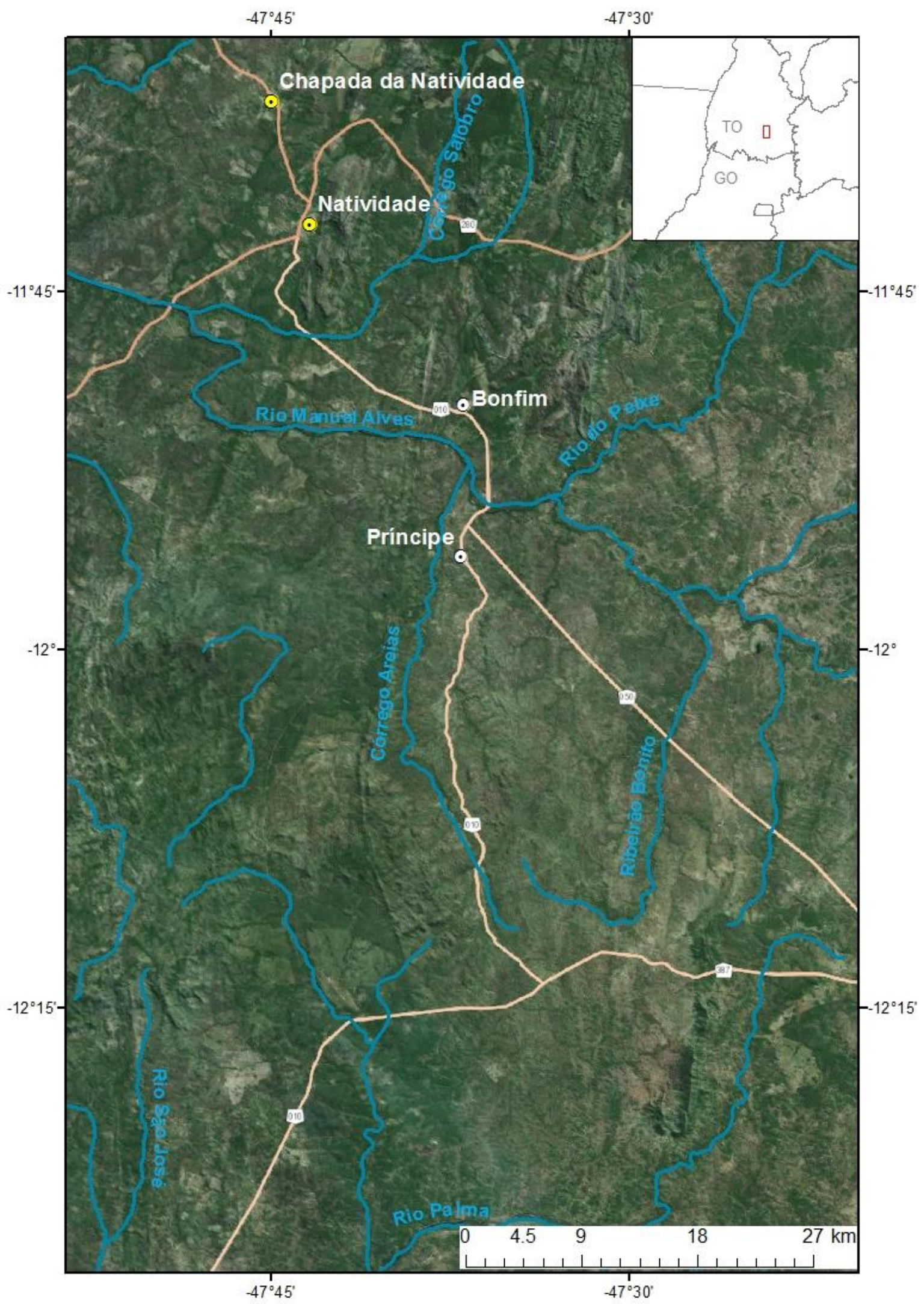

Figura 1.3: Área do projeto de mestrado e localização das cidades de Natividade, Chapada da Natividade e dos povoados de Bonfim e Príncipe. 


\subsection{Trabalhos de campo e métodos analíticos}

Amostras coletadas durante o Trabalho Final de Graduação-2012 foram incorporadas ao presente projeto de mestrado. Entretanto, algumas unidades precisavam ser melhor amostradas. Por isso, no segundo semestre de 2013 foram realizados quatro dias de trabalho de para aquisição de mais material e para verificação de alguns pontos mapeados no TF-2012.

De posse de grande número de amostras, foi possível realizar os procedimentos descritos nos próximos tópicos.

\subsubsection{Lâminas delgadas}

80 lâminas delgadas com espessura de $30 \mu \mathrm{m}$ foram confeccionadas e descritas utilizando microscópio óptico.

\subsubsection{Litogeoquímica}

\section{Preparação de amostras}

Dentre as amostras coletadas, as mais representativas das unidades e que registram menos efeitos intempéricos e hidrotermais foram preparadas para análise geoquímica.

As amostras foram pulverizadas em moinho vibratório, utilizando panela de vídia ou ágata. A moagem na panela de vídia provoca contaminação em Co e $\mathrm{W}$, na ordem de dezenas de ppm para o Co, e de centenas de ppm para o W. Nas tabelas de resultado, estão discriminadas quais amostras foram preparadas em cada panela.

A contaminação em $\mathrm{SiO}_{2}$ pela panela de ágata não é significativa, pois comparando os resultados geoquímicos de amostras preparadas em cada tipo de panela, observa-se que a contaminação em $\mathrm{SiO}_{2}$ é inferior a $1 \%$ e não altera a classificação da rocha.

\section{Técnicas analíticas}

Após a moagem, as amostras pulverizadas foram encaminhadas à AcmeLabs ${ }^{\mathrm{TM}}$ para análise. Elementos maiores e parte dos elementos menores são analisados por ICP-ES, enquanto elementos traços são determinados por ICP-MS.

Amostras analisadas por ICP-ES (Inductively Coupled Plasma -Emission Spectrometry) são preparadas e introduzidas no espectrômetro, onde são ionizadas por fonte 
de plasma induzido em Ar. As propriedades da energia eletromagnética emitida em decorrência da ionização permitem a determinação e quantificação dos elementos na amostra.

O método ICP-ES se diferencia do ICP-MS (Inductively Coupled Plasma - Mass Spectrometry) porque, enquanto o ICP-ES analisa a energia emitida na ionização, o ICP-MS identifica elementos a partir de sua massa. Após serem ionizados pelo plasma induzido em Ar, os átomos são acelerados por uma câmara que contém um magneto, e esse desvia as partículas de seu trajeto de acordo com sua carga e massa. Detectores captam feixes de íons para cada massa, e a intensidade do feixe é proporcional à quantidade do elemento na amostra.

O pó de cada amostra é sinterizado a $1000^{\circ} \mathrm{C}$ para determinação da porcentagem de massa perdida no aquecimento, a perda ao fogo.

Tabela 1.1: Limite de detecção dos elementos analisandos na geoquímica de rocha total.

\begin{tabular}{|c|c|c|c|c|c|c|c|c|}
\hline & \multicolumn{2}{|c|}{ Limite de detecção } & \multicolumn{3}{|c|}{ Limite de detecção } & \multicolumn{3}{|c|}{ Limite de detecção } \\
\hline $\mathrm{SiO}_{2}$ & $\%$ & 0.01 & $\mathrm{Ga}$ & PPM & 0.5 & $\mathrm{La}$ & PPM & 0.1 \\
\hline $\mathrm{Al}_{2} \mathrm{O}_{3}$ & $\%$ & 0.01 & Hf & PPM & 0.1 & $\mathrm{Ce}$ & PPM & 0.1 \\
\hline $\mathrm{Fe}_{2} \mathrm{O}_{3}$ & $\%$ & 0.04 & $\mathrm{Nb}$ & PPM & 0.1 & $\operatorname{Pr}$ & PPM & 0.02 \\
\hline $\mathrm{MgO}$ & $\%$ & 0.01 & $\mathrm{Rb}$ & PPM & 0.1 & $\mathrm{Nd}$ & PPM & 0.3 \\
\hline $\mathrm{CaO}$ & $\%$ & 0.01 & $\mathrm{Sr}$ & PPM & 0.5 & $\mathrm{Sm}$ & PPM & 0.05 \\
\hline $\mathrm{Na}_{2} \mathrm{O}$ & $\%$ & 0.01 & $\mathrm{Ta}$ & PPM & 0.1 & $\mathrm{Eu}$ & PPM & 0.02 \\
\hline $\mathrm{K}_{2} \mathrm{O}$ & $\%$ & 0.01 & $\mathrm{Th}$ & PPM & 0.2 & $\mathrm{Gd}$ & PPM & 0.05 \\
\hline $\mathrm{TiO}_{2}$ & $\%$ & 0.01 & $\mathrm{U}$ & PPM & 0.1 & $\mathrm{~Tb}$ & PPM & 0.01 \\
\hline $\mathrm{P}_{2} \mathrm{O}_{5}$ & $\%$ & 0.01 & $\mathrm{Sc}$ & PPM & 1 & Dy & PPM & 0.05 \\
\hline $\mathrm{MnO}$ & $\%$ & 0.01 & $\mathrm{~V}$ & PPM & 8 & Ho & PPM & 0.02 \\
\hline $\mathrm{Cr}$ & $\%$ & 0.002 & $\mathrm{Zr}$ & PPM & 0.1 & $\mathrm{Er}$ & PPM & 0.03 \\
\hline LOI & $\%$ & -5.1 & Y & PPM & 0.1 & $\mathrm{Tm}$ & PPM & 0.01 \\
\hline TOTAL & $\%$ & 0.01 & $\mathrm{Cu}$ & PPM & 0.1 & $\mathrm{Yb}$ & PPM & 0.05 \\
\hline $\mathrm{Ba}$ & PPM & 1 & $\mathrm{Zn}$ & PPM & 1 & $\mathrm{Lu}$ & PPM & 0.01 \\
\hline Cs & PPM & 0.1 & $\mathrm{~Pb}$ & PPM & 0.1 & $\mathrm{Ni}$ & PPM & 0.1 \\
\hline
\end{tabular}

\subsubsection{Sm-Nd}

Geoquímica dos elementos Sm e Nd

$\mathrm{Sm}$ e $\mathrm{Nd}$ são elementos terras raras que ocorrem em minerais formadores de rochas. Um dos isótopos de $\mathrm{Sm}$, o ${ }^{147} \mathrm{Sm}$, não é estável e decai para o ${ }^{143} \mathrm{Nd}$, emitindo uma partícula $\alpha$ e obedecendo à equação do decaimento: 


$$
\frac{{ }^{143} \mathrm{Nd}}{{ }^{144} \mathrm{Nd}}=\left(\frac{{ }^{143} \mathrm{Nd}}{{ }^{144} \mathrm{Nd}}\right)_{\mathrm{i}}+\frac{{ }^{147} \mathrm{Sm}}{{ }^{144} \mathrm{Nd}}\left(e^{\lambda t}-1\right)
$$

Equação 1.1:: Equação do decaimento de Sm. A quantidade de ${ }^{143} \mathrm{Nd}$ depende de quanto ${ }^{143} \mathrm{~N}$ a amostra já possuía na cristalização e quanto foi produzido pelo decaimento de $\mathrm{Sm}$ no tempo t. $\lambda$ é a constante de decaimento.

Embora a meia vida do ${ }^{147} \mathrm{Sm}$ seja muito alta $\left(T_{1 / 2}=1.06 \times 10^{11}\right.$ anos $)$, ele pode ser usado na datação de rochas. No presente trabalho, o método Sm-Nd não será utilizado na datação, mas na interpretação da granitogênese que formou o embasamento paleoproterozóico, uma vez que a geração de ${ }^{143} \mathrm{Nd}$ fornece pistas sobre a evolução geoquímica do planeta.

Elementos terras raras (ETR) tendem a formar íons de carga +3 , cujo raio decresce com o aumento do número atômico do La ao Lu. Em consequência da variação de raio iônico e carga dos ETR, minerais são seletivos no que diz respeito à incorporação de ETR em sua estrutura cristalina. Feldspatos, biotita e apatita tendem a incorporar ETR leves em sua estrutura, enquanto piroxênios, anfibólios e granadas concentram ETR pesados (Faure \& Mensing, 2005).

Sm e Nd pertencem aos ETR leves, mas por ter o raio iônico ligeiramente maior, o $\mathrm{Nd}$ é mais incompatível e se concentra na fase líquida durante a fusão parcial, enquanto Sm permanece no resíduo sólido. Por essa razão, o particionamento do Nd para a fase líquida enriquece o restito em $\mathrm{Sm}$, e consequentemente, em ${ }^{143} \mathrm{Nd}$, o isótopo radiogênico.

Assim, simplificadamente, se considerarmos que condritos representam a composição da Terra não-diferenciada (CHUR - Chondritic Uniform Reservoir), a fusão parcial de rochas condríticas gera um líquido mais félsico, pobre em $\mathrm{Sm}$, e um restito máfico rico em $\mathrm{Sm}$, que ao decair provocaria enriquecimento em ${ }^{143} \mathrm{Nd}$.

A crosta continental foi formada por diferentes processos de geração de magmas félsicos progressivamente empobrecidos em Sm e consequentemente em ${ }^{143} \mathrm{Nd}$, em relação ao manto depletado, que representaria o restito da fusão. $\mathrm{O}$ manto que não foi submetido a processos de fusão parcial não é depletado e representa a composição da Terra primordial, o CHUR (Faure \& Mensing, 2005).

Por meio de artifícios gráficos e matemáticos, é possível observar essa relação: 


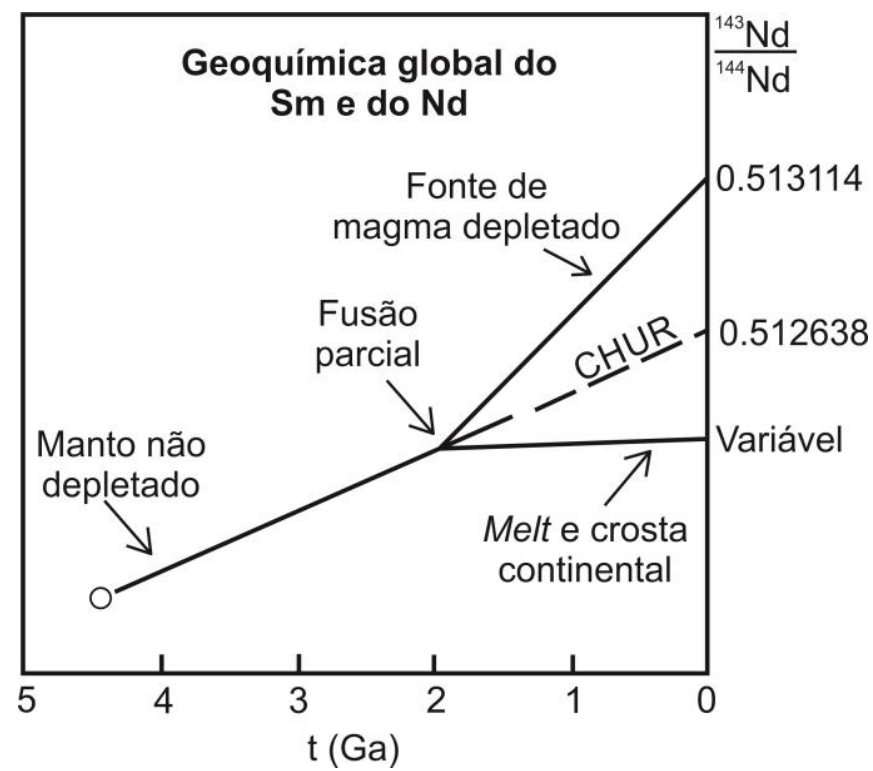

Figura 1.4: Efeito da fusão parcial do manto na evolução isotópica de $\mathrm{Nd}$ na crosta continental e no manto residual (depletado). Assume-se que o manto não depletado tem a mesma razão $\mathrm{Sm} / \mathrm{Nd}$ do CHUR (Modificado de Faure \& Mensing, 2005).

\section{Preparação de amostras}

As amostras pulverizadas enviadas à ACMELabs ${ }^{\mathrm{TM}}$ também foram encaminhadas ao Laboratório de Geocronologia da Universidade de Brasília para análise isotópica de Sm e Nd.

O tratamento do pó de rocha total envolve uma série de etapas que visam separar somente o Sm e o Nd de cada amostra. Essas etapas incluem dissolução do pó da rocha total em ácidos fortes $\left(\mathrm{HNO}_{3}, \mathrm{HF}\right.$ e $\left.\mathrm{HCl}\right)$ e duas colunas de separação cromatográfica: uma para concentração dos elementos terras raras e a segunda para obtenção do Sm e do $\mathrm{Nd}$ da amostra.

Todo o procedimento, com exceção da moagem, é realizado pela equipe do Laboratório de Geocronologia da UnB.

\section{Técnicas analíticas}

A análise laboratorial de Sm e Nd, por TIMS (Thermal Ionization Mass Spectrometry), seguiu o método de Gioia \& Pimentel (2000).

Após a preparação, as amostras são introduzidas no TRITON ${ }^{\mathrm{TM}}$ Plus Multicollector, um espectrômetro de massa de ionização por fonte térmica. A termo-ionização consiste em depositar o material a ser analisado sobre um filamento metálico que ao ser submetido a uma corrente elétrica, aumenta sua temperatura a ponto de ionizar o material depositado sobre ele.

Os íons são carregados através de uma câmara por um gás inerte (He) e acelerados em decorrência da existência de um magneto capaz também de desviar as partículas de sua trajetória. O desvio sofrido pelas partículas é diretamente proporcional à sua carga e inversamente proporcional à sua massa. O sistema de detecção registra a intensidade do feixe 
de íons para cada massa e o resultado fornecido pelo laboratório expressa as concentrações de $\mathrm{Sm}$ e $\mathrm{Nd}$ em ppm e as razões ${ }^{147} \mathrm{Sm} /{ }^{144} \mathrm{Nd} \mathrm{e}{ }^{143} \mathrm{Nd} /{ }^{144} \mathrm{Nd}$.

Os resultados foram tratados no ISOPLOT 4.15 (Ludwig, 2008).

\subsubsection{U-Pb}

Geoquímica dos elementos $U$ e Pb

$\mathrm{O}$ decaimento de $\mathrm{U}$ e Th para isótopos estáveis de $\mathrm{Pb}$ é a base de importantes métodos de datação.

U e Th são membros da série dos actinídeos e por terem configurações eletrônicas similares, apresentam também características químicas similares. Ambos ocorrem na natureza

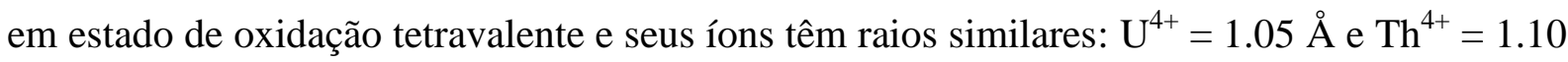
$\AA$ A (Faure \& Mensing, 2005).

A concentração de U e Th em silicatos é muito baixa, da ordem de poucos ppm. Esses elementos ocorrem principalmente em minerais acessórios, nos quais são constituintes principais ou substituem outros elementos. Zircão, torita, allanita, monazita, apatita e titanita são exemplos de fases acessórias que incorporam U e Th em sua estrutura.

O U tem três isótopos: ${ }^{238} \mathrm{U},{ }^{235} \mathrm{U}$ e ${ }^{234} \mathrm{U}$, todos radioativos. O Th existe como ${ }^{232} \mathrm{Th}$, mas outros cinco isótopos instáveis são produtos intermediários do decaimento de ${ }^{238} \mathrm{U},{ }^{235} \mathrm{U}$ e ${ }^{232}$ Th.

O isótopo mais abundante de urânio é o ${ }^{238} \mathrm{U}$, e seu decaimento, em branch, gera ${ }^{206} \mathrm{~Pb}$ como produto final estável. O decaimento de ${ }^{235} \mathrm{U}$ tem como produto final, o ${ }^{207} \mathrm{~Pb}$. E o decaimento de ${ }^{232} \mathrm{Th}$ tem como produto final, ${ }^{208} \mathrm{~Pb}$.

$\mathrm{A}$ acumulação de isótopos radiogênicos de $\mathrm{Pb}$ pelo decaimento de seus respectivos pais é governada por equações derivadas da lei da radioatividade. As equações são escritas em função das razões ${ }^{206} \mathrm{~Pb} /{ }^{204} \mathrm{~Pb},{ }^{207} \mathrm{~Pb} /{ }^{204} \mathrm{~Pb}$ e ${ }^{208} \mathrm{~Pb} /{ }^{204} \mathrm{~Pb}$, porque ${ }^{204} \mathrm{~Pb}$ é o único isótopo estável não radiogênico.

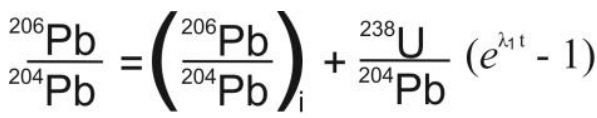

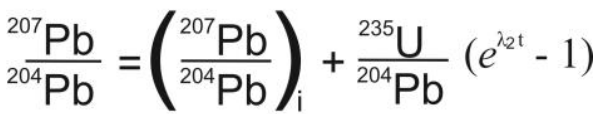

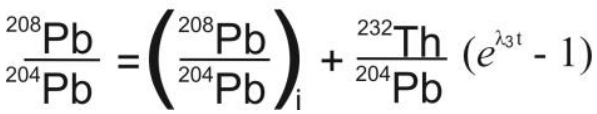

Equação 1.2: Equações do decaimento de ${ }^{238} \mathrm{U},{ }^{235} \mathrm{U} \mathrm{e}^{232} \mathrm{Th}$. 
$\mathrm{Na}$ datação de minerais que incorporam $\mathrm{U}$ ou Th em sua estrutura, a idade é calculada a partir as equações apresentadas na figura 1.6. As idades só são concordantes se o mineral se comportou como um sistema fechado para $\mathrm{U}, \mathrm{Th}, \mathrm{Pb}$ e filhos intermediários, se valores corretos são usados para a concentração inicial de $\mathrm{Pb}$, se as constantes de decaimento estiverem corretas, se não houve fracionamento de $\mathrm{U}$ e se os resultados analíticos são acurados e livres de erros sistemáticos (Faure \& Mensing, 2005).

Como U é um elemento móvel em estado oxidado $\left(\mathrm{UO}_{2}\right)^{2+}$, não é raro que ocorra perda de U durante o intemperismo. Além disso, a emissão de partículas a pode causar danos à estrutura cristalina do mineral e facilitar que $\mathrm{Pb}$ também seja perdido. Por esses motivos, idades ${ }^{235} \mathrm{U}_{-}{ }^{207} \mathrm{~Pb},{ }^{238} \mathrm{U}_{-}{ }^{206} \mathrm{~Pb}$ e ${ }^{232} \mathrm{Th}^{-}{ }^{208} \mathrm{~Pb}$ raramente são concordantes.

Felizmente, procedimentos matemáticos foram desenvolvidos para solucionar esse problema e é possível encontrar idades representativas para rochas que apresentam idades discordantes.

A datação em zircão $\left(\mathrm{ZrSiO}_{4}\right)$ é eficiente por se tratar de mineral que incorpora pouco $\mathrm{Pb}$ em sua estrutura, mas que aceita grande quantidade de $\mathrm{U}$, cerca de $1350 \mathrm{ppm}$, e Th, cerca de 550 ppm. A presença de U e Th em cristais de zircão pode ser atribuída à substituição de $\mathrm{Zr}^{4+}$ (raio iônico $0.87 \AA$ ) por $\mathrm{U}^{4+}\left(1.05 \AA\right.$ ) e $\mathrm{Th}^{4+}(1.10 \AA$ ). Enquanto $\mathrm{U}$ e Th podem substituir o $\mathrm{Zr}$, em quantidade limitada dada a diferença de raio iônico, o $\mathrm{Pb}^{2+}$ é excluído da estrutura cristalina, em consequência de seu raio iônico grande e de sua baixa carga. Assim, o $\mathrm{Pb}$ presente no zircão é, a princípio, radiogênico.

\section{Preparação de amostras}

No presente trabalho, todas as datações realizadas foram feitas pelo método $\mathrm{U}-\mathrm{Pb}$, utilizando LA-ICP-MS (Laser Ablation - Inductively coupled plasma mass spectrometry) em zircão. LA-ICP-MS consiste em um equipamento de ablação a laser acoplado ao espectrômetro de massa.

A preparação de amostras analisadas por esse método segue as seguintes etapas:

- Britagem da amostra;

- Fragmentação em partículas menores (utilizando SELFRAG High Voltage Pulse Power Fragmentation);

- Bateamento da amostra fragmentada para obtenção de minerais densos;

- Separação magnética no FRANTZ;

- Concentração manual de cristais de zircão na lupa;

- Preparação do mount e resinagem com epofix (resina da marca Struers); 
- Os mounts já resinados são lixados e polidos para exporem superfície homogênea dos cristais de zircão;

- Limpeza dos mounts com acetona

- Imageamento dos mounts em microscópio eletrônico por elétrons retroespalhados (backscattered electrons) ou por catodoluminescência.

Após todas essas etapas, os mounts com cerca de 40 cristais de zircão são introduzidos no New-Wave UP213 Nd:YAG laser $(\lambda=213 \mathrm{~nm})$, equipamento de ablação a laser acoplado ao ICP-MS multi-coletor Thermo Finnigan Neptune.

\section{Técnicas analíticas}

Análises isotópicas U-Pb seguiram os procedimentos descritos por Bühn et al. (2009). A análise por LA-ICP-MS consiste em incidir um feixe laser sobre o cristal de zircão, e ao fazer isso, parte da amostra é vaporizada. O material vaporizado e ionizado é transportado para dentro do espectrômetro por gás inerte, acelerado através de uma câmara que contém um magneto até atingir o sistema coletor, que mede a intensidade do feixe elétrico correspondente a cada massa medida. A medição de massas diferentes é possível porque o magneto desvia as partículas de acordo com sua massa e carga.

O diâmetro do laser incidente nos cristais de zircão é de $30 \mu \mathrm{m}$, frequência de $10 \mathrm{~Hz}$ e energia variando entre 78 e $80 \%$. A cada quatro análises nos cristais de zircão das amostras, uma análise é feita no cristal de zircão padrão GJ-1 (Jackson et al., 2004).

A configuração do ICP-MS multi-coletor Thermo Finnigan Neptune permite a medição de ${ }^{238} \mathrm{U},{ }^{232} \mathrm{Th},{ }^{204} \mathrm{~Pb},{ }^{206} \mathrm{~Pb},{ }^{207} \mathrm{~Pb},{ }^{208} \mathrm{~Pb}$ e ${ }^{202} \mathrm{Hg}$ em volts ou contagens por segundo (cps). Tais medidas são posteriormente reduzidas em planilha Excel e o resultado, tratado e corrigido no Excel, fornece razões isotópicas cujo erro é expresso em $1 \sigma \%$. Os dados foram trabalhados no ISOPLOT 4.15 (Ludwig, 2008), suplemento do Excel que permite a construção do diagrama da concórdia (Wetherill, 1956).

\subsubsection{Química Mineral - Microssonda Eletrônica (MSE)}

Preparação de amostras

A análise em microssonda eletrônica foi realizada para investigação em micro-escala de minerais cuja composição é interessante para interpretação geoquímica. 
Foi necessário polir as lâminas e metalizá-las com uma camada fina de carbono (250 Å). A metalização de carbono é aplicada, por evaporação em alto-vácuo, para cobrir a superfície da amostra com material condutor e evitar o fenômeno de "carga elétrica".

\section{Técnicas analíticas}

Na miscrossonda eletrônica, a amostra é bombardeada por um feixe de elétrons que produz grande número de efeitos no material alvo: raios $\mathrm{X}$, elétrons retroespalhados, elétrons transmitidos, elétrons secundários, elétrons Auger, catodoluminescência e calor.

A composição dos minerais analisados é determinada por comparação com as intensidades de raios $\mathrm{X}$ de minerais com composições conhecidas (padrões) e expressa em porcentagem peso de óxidos.

Dois sistemas analisadores são utilizados em MSE, o de Dispersão por Energia (EDS), que fornece análises qualitativas e semi-quantitativas, e o de Dispersão por Comprimento de Onda (WDS), que fornece análises quantitativas.

Neste trabalho, grãos de biotita, muscovita, clorita e granada foram analisados na microssonda eletrônica, pelo sistema WDS. O aparelho utilizado é do modelo JEOL JXA8230 e o sistema WDS foi configurado para operar com $20 \mathrm{kV}$, 20nA e tempo de contagem de 10s. Os padrões utilizados foram minerais naturais: andradita $\left(\mathrm{SiO}_{2}\right.$ e $\left.\mathrm{CaO}\right)$, albita $\left(\mathrm{Na}_{2} \mathrm{O}\right)$, fosterita $(\mathrm{MgO})$, topázio $(\mathrm{F})$, córindon $\left(\mathrm{Al}_{2} \mathrm{O}_{3}\right)$, microclínio $\left(\mathrm{K}_{2} \mathrm{O}\right)$, vanadinita $\left(\mathrm{Cl} \mathrm{e} \mathrm{V}_{2} \mathrm{O}_{3}\right)$, pirofanita $\left(\mathrm{TiO}_{2}\right.$ e $\left.\mathrm{MnO}\right)$, hematita $\left(\mathrm{Fe}_{2} \mathrm{O}_{3}\right)$ e barita $(\mathrm{BaO})$. A porcentagem de $\mathrm{H}_{2} \mathrm{O}$ é calculada por diferença, para que a soma total seja $100 \%$. As análises foram realizadas no Laboratório de Microssonda Eletrônica do Instituto de Geociências da Universidade de Brasília. 


\section{ConteXto Geológico REgional}

A área de estudo se insere no segmento setentrional da Faixa Brasília (FB), dentro do domínio rochas paleoproterozóicas interpretadas como o embasamento da faixa.

$\mathrm{O}$ embasamento da FB, em sua porção norte, aflora continuamente por centenas de quilômetros e autores sugerem que ele seja a borda retrabalhada do Cráton do São Francisco (Cruz \& Kuyumjian, 1998). A leste, coberturas sedimentares neoproterozóicas do Grupo Bambuí recobrem rochas do embasamento e acima delas repousa discordantemente a sequência cretácea do Grupo Urucuia. A sul, as rochas do embasamento são recobertas por sedimentos do Grupo Araí e, a norte, a bacia do Parnaíba também as oculta. O limite oeste do embasamento paleoproterozóico é dado pela Falha Rio dos Bois, que o coloca em contato com o Arco Magmático de Goiás (Pimentel \& Fuck, 1992).

A oeste do Arco Magmático de Goiás, rochas paleoproterozóicas do embasmaento da Faixa Araguaia afloram adjacentes ao Lineamento Transbrasiliano, e apesar de não fazerem parte da FDB, são de idade muito próxima às estudadas neste projeto de mestrado e serão brevemente descritas neste capítulo.

Os próximos tópicos resumem o desenvolvimento da FDB e abordam com maior detalhe as rochas de idade paleoproterozóica que afloram em meio a esse orógeno neoproterozóico.

\subsection{A Faixa Brasília: síntese sobre seus elementos e evolução}

A Faixa Brasília (FB) integra a Província Tocantins (Almeida et al., 1981; Figura 2.1), um sistema orogênico desenvolvido entre os paleocontinentes Amazônico, São Francisco e Paranapanema. O bloco Paranapanema é completamente encoberto por sedimentos da Bacia do Paraná, mas seus limites são inferidos por dados gravimétricos (Mantovani \& Brito Neves, 2005).

Três cinturões orogênicos formam a Província Tocantins: a Faixa Araguaia e a Faixa Paraguai bordejam o Cráton Amazônico a leste e a sul, respectivamente, e a Faixa Brasília se desenvolveu na margem oeste do Cráton do São Francisco. Todas se desenvolveram no contexto de eventos colisionais neoproterozóicos de fase inicial de amálgama do supercontinente Gondwana (Valeriano et al., 2008). 


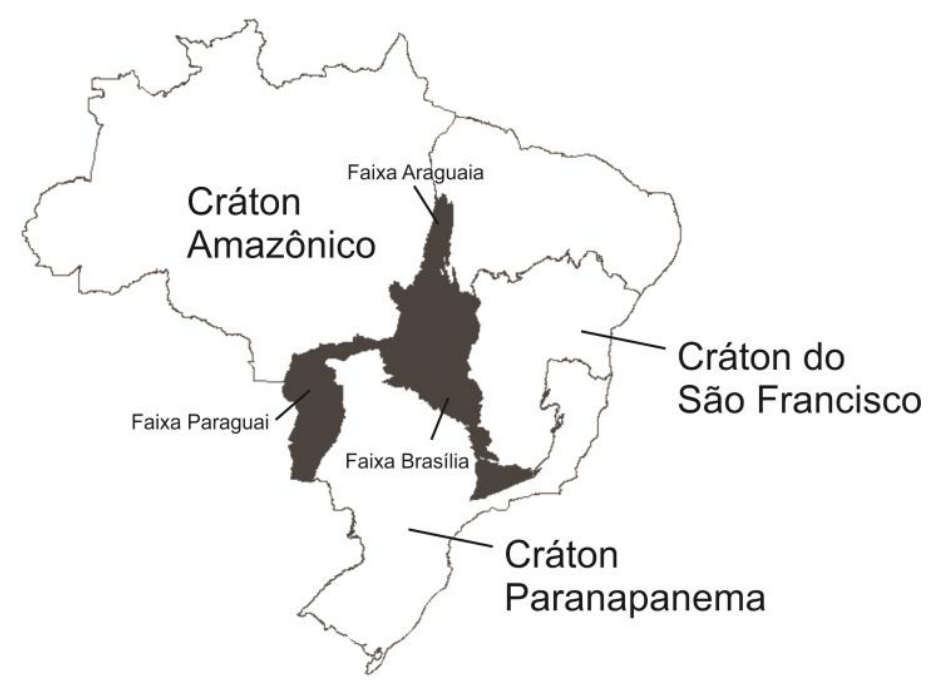

Figura 2.1: Província Tocantins (Almeida et al., 1981).

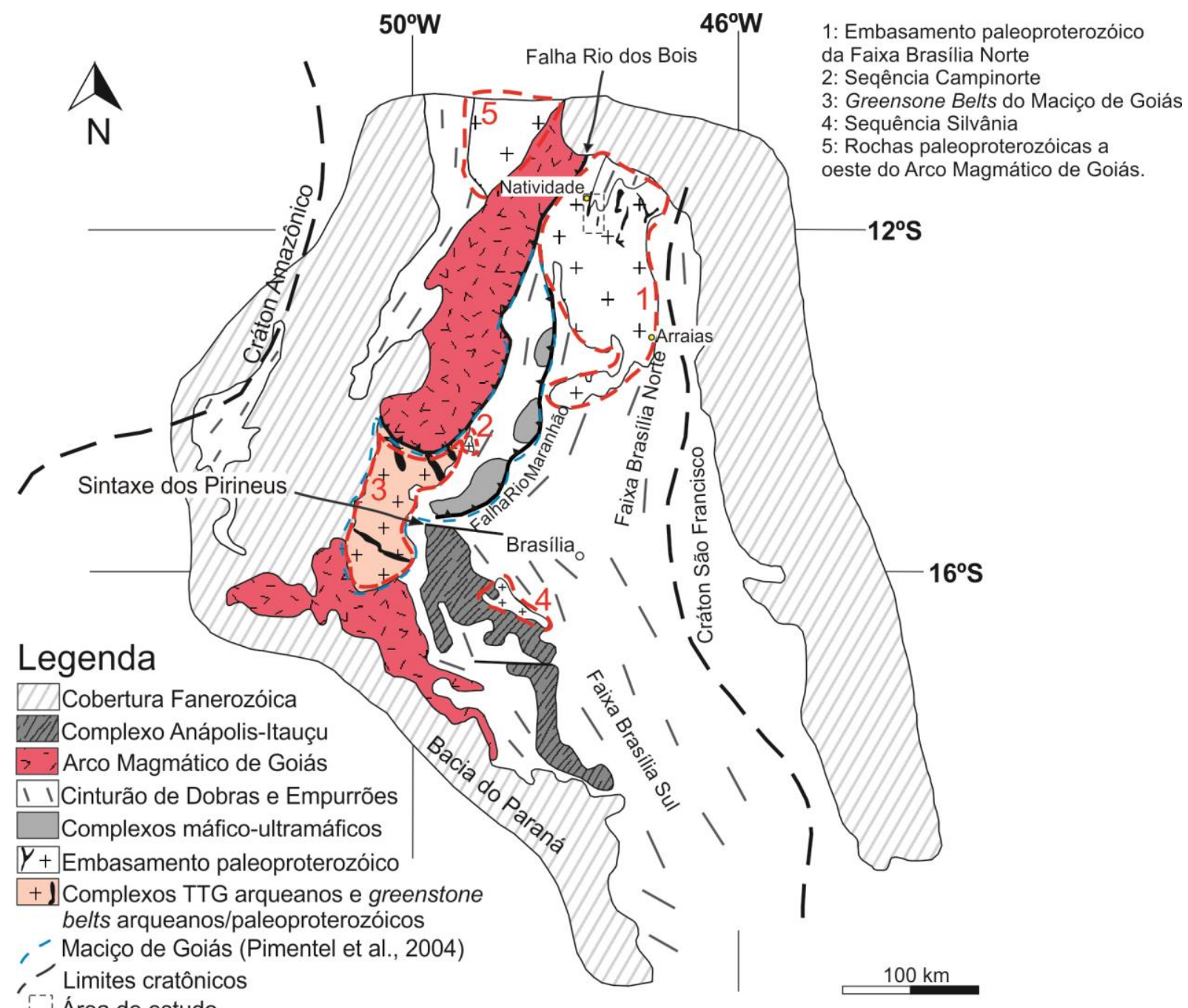

Área de estudo

Figura 2.2: Mapa esquemático da Faixa Brasília. Áreas circuladas em vermelho são terrenos de idade paleoproterozóica (Modificado de Pimentel et al., 2006; Oliveira et al., 2006). 
A FB compreende espessas sequências sedimentares dobradas e terrenos empurrados em direção ao Cráton do São Francisco. Sua evolução, diacrônica, resultou na formação de dois segmentos: a Faixa Brasília Norte e a Faixa Brasília Sul, de direções SW-NE e SE-NW, respectivamente (Figura 2.2). Os dois segmentos se interceptam na Sintaxe dos Pirineus (Araújo Filho, 2000), uma estrutura curva cuja concavidade para leste reflete a acomodação de terrenos à margem de geometria irregular do Cráton do São Francisco. Araújo Filho (2000) sugere também que o segmento norte da faixa seja mais jovem que o segmento sul.

Os principais componentes da faixa são: (i) o embasamento paleoproterozóico, (ii) o Arco Magmático de Goiás, (iii) as coberturas sedimentares existentes entre o Cráton do São Francisco e o arco magmático, (iv) o núcleo metamórfico e (v) o Maciço de Goiás.

\subsubsection{Embasamento granítico paleoproterozóico}

A área mais contínua de afloramentos de rochas paleoproterozóicas fica no segmento setentrional da Faixa Brasília, entre Arraias e Natividade, no Tocantins.

Outras janelas do embasamento são descritas no segmento sul da faixa: sequência vulcano-sedimentar Silvânia (Fischel et al., 2001), sequência Campinorte (Oliveira et al., 2006; Della Giustina et al., 2009) e suítes plutônicas associadas, Jurubatuba e Pau de Mel, respectivamente.

Esses terrenos são paleoproterozóicos têm idades superiores a 2.0 Ga e granitogênese característica de ambiente convergente (Cruz \& Kuyumjian, 1998; Botelho et al., 2006; Fischel et al., 2001). No fim do Paleoproterozóico, as associações litológicas mudam, e passam a ser características de ambiente extensional.

$\mathrm{Na} F B$, a tafrogênese estateriana é representada pelos granitos anorogênicos da Província Estanífera de Goiás e pela sequência sedimentar de rift intracontinental do Grupo Araí, de 1.77 Ga (Fuck et al., 2005).

Dados de refração sísmica profunda sugerem que o embasamento seja a borda do cráton São Francisco retrabalhada na Orogenia Brasiliana (Fuck et al., 2005), e dados geocronológicos e estratigráficos indicam que o Grupo Araí é correlato ao Supergrupo Espinhaço.

O Grupo Natividade é a sequência sedimentar plataformal que repousa discordantemente sobre o embasamento em sua extremidade norte. Não existem datações precisas, mas acredita-se que ele seja cronocorrelato ao Grupo Araí, embora não apresente características de bacia intracontinental (Dardenne \& Saboia, 2007). 
A partir do Mesoproterozóico, inicia-se a deposição de sedimentos plataformais à borda oeste do Cráton do São Francisco, que viriam a compor o cinturão de dobras e empurrões desenvolvido no Brasiliano.

\subsubsection{Coberturas Sedimentares}

Entre o Cráton do São Francisco e o Arco Magmático de Goiás, espessas camadas sedimentares foram depositadas durante o Mesoproterozóico e o Neoproterozóico. Existe grande dificuldade em se individualizar sequências sedimentares e caracterizá-las quanto ao ambiente deposicional porque a Orogenia Brasiliana promoveu intenso sistema de empurrões e nappes que desorganizou a estratigrafia. Além disso, alguns grupos não são contínuos em toda extensão da faixa, estando restritos ao segmento setentrional ou ao meridional.

Os Grupos Araí, Natividade e Serra da Mesa são formados por rochas sedimentares depositadas em ambiente continental a plataformal. São interpretados como depósitos relacionados a bacias geradas na Tafrogênese Estateriana e são mais velhos que os demais grupos. O Grupo Serra da Mesa é correlacionado à fase pós-rift do Grupo Araí (Marques, 2009), mas existem proposições que o classificam como sin-orogênico ao evento Brasiliano (Pimentel et al., 2011). Assim, apesar de comporem dobras e empurrões, são sequências mais velhas, depositadas em um contexto diferente dos demais grupos meso-neoproterozóicos.

Os grupos Paranoá, Canastra e Vazante correspondem à margem passiva do Cráton do São Francisco, enquanto os grupos Araxá e Ibiá são interpretados como depósitos sinorogênicos de forearc, cujo arco adjacente é o Arco Magmático de Goiás. O desenvolvimento de uma bacia foreland nos estágios finais do Brasiliano propiciou a deposição do Grupo Bambuí (Pimentel et al., 2011).

A deformação e o metamorfismo dos sedimentos aumentam de leste para oeste. No extremo leste da faixa, o grupo Bambuí ocorre indeformado, compondo estratos subhorizontais.

\subsubsection{Arco Magmático de Goiás}

O Arco Magmático de Goiás é um extenso terreno neoproterozóico de crosta juvenil na porção oeste da Faixa Brasília.

As rochas do arco são expostas em duas regiões distintas de Goiás: Mara Rosa e Arenópolis, cidades estas que denominam os dois segmentos do arco. Os dois segmentos do arco apresentam direção NNE e NNW, respectivamente, e são separados pelo Maciço de Goiás e por coberturas sedimentares fanerozóicas. 
As principais unidades do Arco são: (i) sequências vulcano-sedimentares, que ocorrem em cinturões estreitos; e (ii) terrenos tonalítico-granodiorítico-graníticos sintectônicos.

A formação do arco está relacionada a dois eventos magmáticos principais, um entre 890 e 780 Ma, e outro entre 660 e 600 Ma.

$\mathrm{O}$ evento mais antigo foi dominado por magmatismo de arco de ilhas e apresenta valores positivos de $\varepsilon_{\mathrm{Nd}}$, enquanto o evento mais novo apresenta grau variado de contaminação crustal. Isso indica a evolução de um arco de ilhas para uma margem continental ativa, no final da Orogenia Brasiliana, quando o arco é amalgamado à margem oeste do Cráton do São Francisco (Laux et al., 2005).

\subsubsection{Maciço de Goiás}

O Maciço de Goiás, localizado na porção central da FB, é interpretado como um bloco alóctone acrescionado ao orógeno brasiliano no final do Neoproterozóico (Pimentel et al., 2000). O Maciço é composto por (i) um núcleo de greenstone belts e terrenos TTG; (ii) rochas metessedimentares plataformais paleo-mesoproterozóicos do Grupo Serra da Mesa e (iii) complexos máfico-ultramáficos acamadados de Barro Alto, Niquelândia e Canabrava do Meso-Neoproterozóico, associados a sequências vulcano-sedimentares.

O limite leste do Maciço de Goiás é a Falha Rio Maranhão, adjacente aos complexos acamadados. O limite oeste é a Falha Rio dos Bois, que coloca o Arco Magmátio de Goiás em contato com o maciço.

Em uma pequena área na porção central do maciço, afloram rochas do Complexo Uruaçu. São gnaisses neoproterozóicos metamorfizados em fácies anfibolito e granulito, possivelmente correlatos ao Complexo Anápolis-Itauçu (Della Giustina et al., 2009). Em contato com o Complexo Uruaçu, aflora a sequência vulcanossedimentar Campinorte, paleoproterozóica, composta por rochas meta-vulcanossedimentares associadas a plutônicas ácidas da Suíte Pau de Mel, de composição tonalítica a granítica (Della Giustina, 2007; Della Giustina et al., 2009, Cordeiro et al., 2014).

\subsubsection{Núcleo Metamórfico}

Rochas granulíticas são expostas no Complexo Uruaçu, no Complexo Anápolis-Itauçu (CAI) e nos complexos máfico-ultramáficos acamadados de Barro Alto, Niquelândia e Canabrava.

Dados de Sm-Nd (Pimentel et al., 1999) indicam idades modelo de 1.0 a $1.5 \mathrm{Ga}$, e metamorfismo de alto grau datado entre 670-680 Ma para o CAI. O CAI é composto por 
granulitos orto e para-derivados, migmatitos e ortognaisses, com paragêneses de alto grau metamórfico.

Della Giustina (2009) sugere que o CAI e o Complexo Uruaçu são correlacionáveis, e que tais zonas de alto grau indicariam provável zona de sutura entre o arco magmático e os terrenos do embasamento da Faixa Brasília.

Os complexos de Barro Alto, Niquelândia e Canabrava são expostos por falha de empurrão e atingiram fácies granulito no metamorfismo datado em $760 \mathrm{Ma}$, subsequente à cristalização desses complexos em torno de 780 Ma (Pimentel et al., 2004; 2006). Alguns autores sugerem que esses granulitos representam uma possível sutura entre o Maciço de Goiás e a paleoplaca do São Francisco, se o maciço for considerado um bloco alóctone (Marangoni et al., 1995; Pimentel et al., 1999; Moraes et al., 2006; Jost et al., 2013).

\subsubsection{Evolução da Faixa Brasília}

A quebra de Rodínia foi o evento responsável por gerar massas continentais que viriam a se aglutinar e formar Gondwana. Nas bordas desses paleocontinentes foram depositadas sequências sedimentares plataformais que, na Faixa Brasília, são representadas pelos grupos Paranoá, Canastra e Vazante.

Pimentel et al. (1999) sugerem que concomitante à dispersão dos descendentes de Rodínia, tem-se o desenvolvimento dos primeiros estágios do Arco de Mara Rosa, a fase de magmatismo juvenil de arco de ilha. A composição isotópica dos grupos Araxá e Ibiá mostra contribuição do embasamento paleoproterozóico na sedimentação e de uma fonte mais jovem, coerente com a erosão do Arco Magmático de Goiás.

A progressão dos processos convergentes resultou na acresção do Arco Magmático de Goiás e do Maciço de Goiás à margem oeste do cráton São Francisco por volta de 760 Ma, evidenciada por magmatismo peraluminoso intrusivo no Grupo Araxá (Pimentel et al., 1999). Nesse momento também ocorre mudança nas características da bacia, e tem início a deposição do Grupo Bambuí em ambiente foreland (Dardenne, 2000).

O fechamento do Oceano Goianides, entre os crátons do São Francisco e Amazônico, ocorreu entre 640-570 Ma e foi responsável pelo metamorfismo de alto grau no Complexo Anápolis-Itauçu (Pimentel et al., 1999). 


\subsection{Características dos terrenos paleoproterozóicos da Faixa Brasília}

O Paleoproterozóico na FDB é representado pelo (i) embasamento na porção norte da faixa, (ii) pela Sequência Campinorte, no domínio do Maciço de Goiás; (iii) por intervalos sedimentares no topo de greenstone belts do Maciço de Goiás e (iv) pela Sequência Silvânia, no segmento meridional da faixa (Figura 2.2).

\subsubsection{Embasamento Paleoproterozóico na Faixa Brasília Norte}

O embasamento na Faixa Brasília Norte já foi compartimentado por diversos autores, e engloba os terrenos descritos por Almas-Dianópolis (Costa, 1985), Almas-Conceição do Tocantins (Padilha, 1984), Arraias-Natividade (Fuck et al., 2001) e Cavalcante-Teresina de Goiás -Nova Roma (Botelho, 1992; Botelho et al., 1993). Cada um desses terrenos foi descrito em uma porção do embasamento, nas proximidades de cidades homônimas. São relativamente similares no que diz respeito à geologia, mas exibem ligeiras variações geocronológicas e geoquímicas. De forma geral, são compostos por tonalitos a granitos intrusivos em sequências vulcano-sedimentares.

Nesta dissertação utilizaremos a compartimentação proposta por Fuck et al. (2014): domínio Arraias-Cavalcante e domínio Almas-Conceição do Tocantins (Figura 2.3).

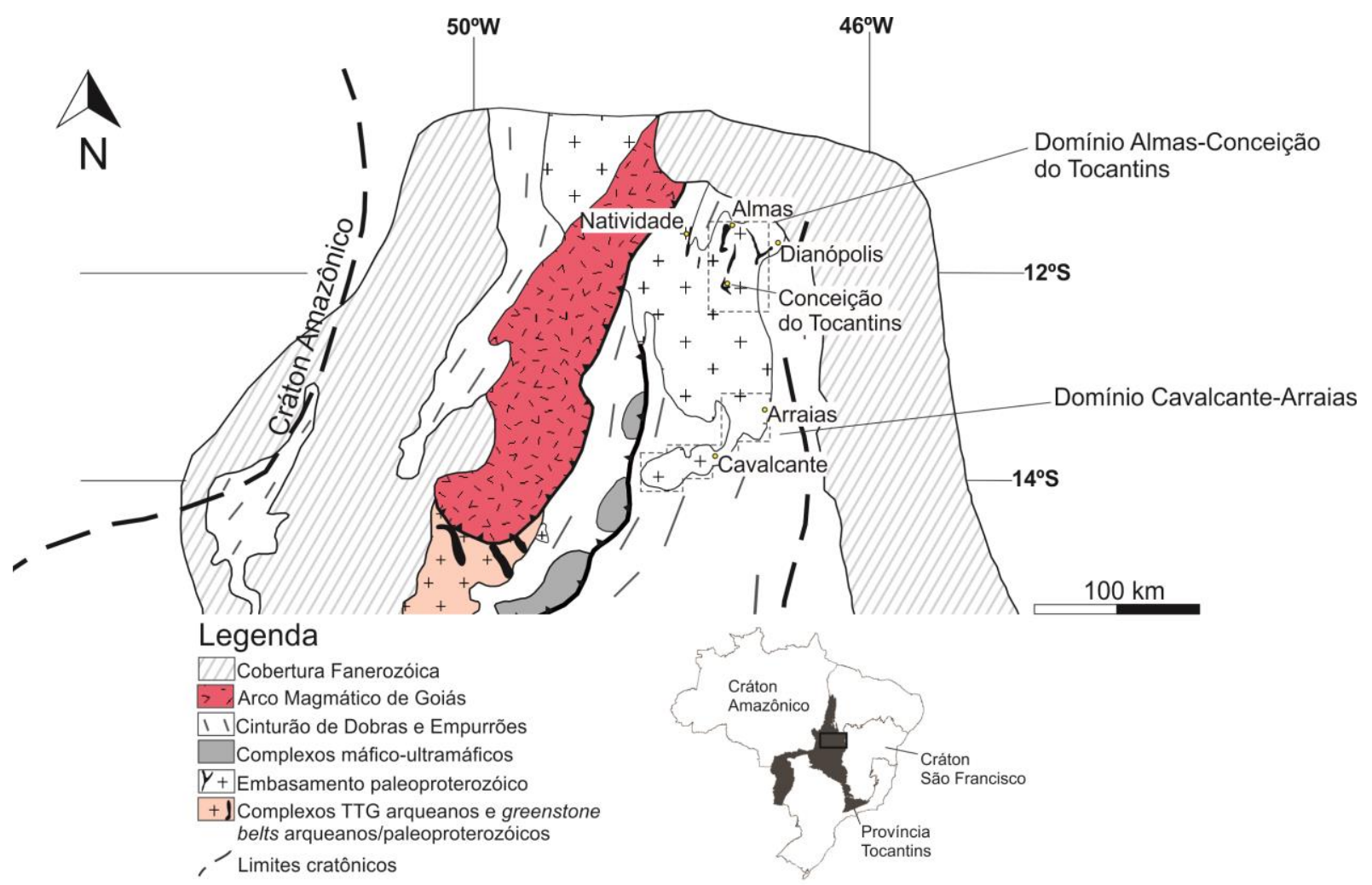

Figura 2.3: Domínios do embasamento da Faixa Brasília Norte (Modificado de Pimentel et al., 2006). 


\section{Domínio Almas - Conceição do Tocantins}

O embasamento da Faixa Brasília entre Almas, Dianópolis e Conceição do Tocantins é composto por tonalitos, granodioritos e granitos intrusivos no Grupo Riachão do Ouro, compartimentado em Formação Córrego do Paiol, na base, e Formação Morro do Carneiro, no topo.

A Formação Córrego do Paiol é constituída por rochas vulcânicas máficas e inclui raras ocorrências de rochas vulcânicas ultramáficas. As rochas vulcânicas máficas são divididas em um grupo de metabasaltos de alto-Fe e outro de alto-Mg (Cruz \&Kuyumjian, 1998)

A Formação Morro do Carneiro é composta por uma sequência de filitos sericíticos com intercalações de formação ferrífera bandada, quartzito, chert, conglomerados e rochas vulcânicas félsicas (Cruz \& Kuyumjian, 1998).

O complexo granito-gnáissico é constituído por plútons granitóides isotrópicos a fracamente foliados, podendo apresentar bandamento gnáissico. Os contatos com o Grupo Riachão do Ouro são por falha ou intrusivos. As rochas graníticas podem ser agrupadas em duas suítes. A Suíte 1 compreende tonalitos, granodioritos, trondhjemitos e quartzo dioritos metaluminosos ricos em anfibólio, que apresentam enclaves máficos. Rochas desta suíte compõem uma série de magmatismo ácido calcialcalino. A Suíte 2 também apresenta trend calcialcalino, é formada principalmente por tonalitos e granodioritos sem anfibólio e, ao contrário da Suíte 1, tende a ser peraluminosa (Cruz \& Kuyumjian, 1996).

A partir do padrão de elementos terras raras e do índice de saturação em alumina, Cruz \& Kuyumjian (1996) sugerem que a Suíte 1 seja produto de fusão mantélica, enquanto a Suíte 2 é resultado da fusão parcial de metabasaltos.

Dados isotópicos mostram idades modelo $\mathrm{Sm}-\mathrm{Nd}$ de $2.58 \mathrm{Ga}$ em metadacito da Formação Córrego do Paiol, e de 2.52 a 2.53 para as rochas graníticas (Cruz \& Kuyumjian, 1999).

Dardenne et al. (2009) obtiveram idade U-Pb de $2206 \pm 13$ Ma em zircão de rocha metavulcânica intermediária da Formação Morro do Carneiro.

Cruz (2001) apresenta idades SHRIMP U-Pb em zircão de $2200 \pm 5$ Ma e $2204 \pm 4 \mathrm{Ma}$ para rochas plutônicas das suítes 1 e 2 , respectivamente. A amostra mais velha encontrada data de $2455 \pm 14 \mathrm{Ma}$, e foi obtida por análise U-Pb em titanita no SHRIMP e corresponde ao complexo Ribeirão das Areias. 
Fuck et al. (2014) dataram diversas rochas de todo o domínio do embasamento e compilaram dados geocronológicos já existentes para o domínio norte, encontrando idades entre 2.0 e $2.386 \mathrm{Ga}$.

Quanto à química dessas rochas, Cruz (2001) mostra que as rochas metabásicas e metaultrabásicas do Grupo Riachão do Ouro apresentam evidência de contaminação crustal e sugere um ambiente tectônico continental para sua formação, um rifte intracontinental ou uma bacia do tipo back arc. Para as rochas graníticas, Cruz (2001) sugere formação em ambiente de arco magmático.

Valores de $\varepsilon_{\mathrm{Nd}}(\mathrm{t})$ para a Suíte 1 variam de -0.15 a -1.37 , e de -0.88 a -4.95 para a Suíte 2. As idades modelo $T_{\mathrm{DM}}$ são de 2.45 a $2.54 \mathrm{Ga}$ e 2.53 a 2.76 , respectivamente para as suítes 1 e 2 (Cruz, 2001).

\section{Domínio Cavalcante-Arraias}

No domínio sul do embasamento, próximo à cidade de Cavalcante, afloram rochas da Suíte Aurumina e da Formação Ticunzal.

Granitos e tonalitos da suíte Aurumina são intrusivos nos xistos e paragnaisses grafitosos da Formação Ticunzal, que é exposta apenas em faixas estreitas e descontínuas principalmente nas bordas dos plútons graníticos da Suíte Aurumina (Botelho et al., 2006).

As fácies da Suíte Aurumina apresentam cristais ígneos de muscovita e lamelas de grafita, indicando caráter peraluminoso compatível com a interpretação de fusão de material crustal para a suíte.

Datações U-Pb em zircão indicam idades entre 2.12 e 2.17 Ga para a Suíte Aurumina e dados Sm-Nd mostram valores $\varepsilon_{\mathrm{Nd}}(\mathrm{t})$ entre -1 e -3 e idades $T_{\mathrm{DM}}$ entre 2.4 e 2.6. Idades modelo Sm-Nd para a Formação Ticunzal apontam para fontes de 2.5 a $2.8 \mathrm{Ga}$, sugerindo que os sedimentos da formação sejam derivados de rochas arqueanas. A natureza peraluminosa da Suíte Aurumina, suas relações de contato com a Fomação Ticunzal, a ocorrência de migmatitos, a presença de grafita residual ou xenólitos grafitosos, em conjunto com dados U$\mathrm{Pb}$ e Sm-Nd, levam a crer que a própria Formação Ticunzal seja a fonte de magmas da Suíte Aurumina (Botelho et al., 2006).

Ainda no domínio Cavalcante-Arraias, são reconhecidos diversos corpos graníticos de idade $1.77 \mathrm{Ga}$ e 1.58 intrusivos na suíte Aurumina. Esses granitos têm caráter anorogênico e são contemporâneos aos eventos extensionais que proporcionaram a deposição do Grupo Araí 
em bacias intracontinentais. Importantes mineralizações de Sn estão hospedadas nesses granitos, que compõem a Província Estanífera de Goiás (Botelho \& Moura, 1998).

\subsubsection{Sequência Campinorte}

Em meio às rochas do Maciço de Goiás, aflora uma sequência de metapsamitos e metapelitos, eventualmente intercalados com gonditos e metacherts, bem como riolitos e depósitos piroclásticos. Essas rochas compõem a sequência Campinorte (Kuyumjian et al., 2004; Oliveira et al., 2006).

Tonalitos, granodioritos e granitos da suíte Pau de Mel são intrusivos na sequência (Pimentel et al., 1997) e datam de 2.18 a $2.16 \mathrm{Ga}$, como indicam dados U-Pb em zircão (Della Giustina et al., 2009; Cordeiro et al., 2014). Idades modelo $T_{\mathrm{DM}} \mathrm{Sm}-\mathrm{Nd}$ variam de 2.1 a 2.7 $\mathrm{Ga}$, e valores de $\varepsilon_{\mathrm{Nd}}(\mathrm{t})$ variam de $-2.14 \mathrm{a}+3.36$ para a suíte, mostrando predominância de magmas juvenis na sequência. Della Giustina et al. (2009) sugere que as rochas vulcânicas da Sequência Campinorte e as plutônicas da suíte Pau de Mel foram formadas em ambiente de arco magmático.

\subsubsection{Greenstone belts do Maciço de Goiás}

Dentro do Maciço de Goiás, o bloco arqueano-paleoproterozóico é composto por seis complexos ortognáissicos, entre os quais ocorrem as faixas greenstone. Os complexos são francamente arqueanos (Jost et al., 2005), mas os greenstone belts têm mostrado idades mais jovens.

Existem variações e peculiaridades na estratigrafia dos greenstone belts, mas de forma geral, na base ocorrem metakomatiitos e formações ferríferas, seguidos por metabasaltos, sedimentos químicos e, no topo, sedimentos clásticos.

As idades dos greenstone belts ainda não são precisamente estabelecidas, mas diversas datações sugerem que a bacia na qual sedimentos foram depositados ainda estava ativa durante o Paleoproterozóico.

Datação SHRIMP U-PB em zircão detrítico de metagrauvaca do greenstone belt de Crixás mostra que os grãos de zircão mais jovens têm idade $2212 \pm 36 \mathrm{Ma}$, (Tassinari et al., 2006). Jost et al., (2008) dataram zircão de metagrauvaca também de Crixás e obtiveram intervalo de $3354 \pm 40 \mathrm{Ma}$ a $2209 \pm 28 \mathrm{Ma}$, por U-Pb em LA-ICP-MS. Jost et al., (2008) analisaram também zircões de formação ferrífera e obtiveram duas populações: uma, concordante, de $2627 \pm 19$ Ma e outra com intercepto superior em $2232 \pm 39$ Ma, em rochas calcissilicáticas do greenstone de Pilar de Goiás. 
Apesar dessas idades paleoproterozóicas, também existem datações arqueanas: komatiitos de Crixás geraram idades isocrônicas Sm-Nd em rocha total de $2825 \pm 98 \mathrm{Ma}$ (Arndt et al., 1989) e $3000 \pm 70 \mathrm{Ma}$ (Fortes et al., 2003). Nos greenstone belts de Serra de Santa Rita e Faina, Resende et al. (1999) obtiveram idades modelo Sm-Nd das seções metassedimentares ente 3.0 e $2.7 \mathrm{Ga}$, sugestivo de área fonte arqueana.

Esses dados indicam que, mesmo que as seções vulcânicas de Crixás, Faina e Serra de Santa Rita sejam arqueanas, é possível que o pacote sedimentar seja paleoproterozóico, em sua maioria.

\subsubsection{Sequência Silvânia}

A sequência Silvânia aflora no segmento meridional da FB, em meio a rochas metassedimentares do Grupo Araxá e a rochas de alto grau metamórfico do Complexo Anápolis-Itauçu.

A sequência, exposta nas proximidades da cidade homônima, é caracterizada por uma faixa estreita de rochas metavulcânicas félsicas, anfibolitos e rochas metassedimentares. O Granito Jurubatuba ocorre em contanto com a sequência, e a presença de xenólitos de rocha básica e de rocha sedimentar indicam que ele é intrusivo na sequência Silvânia (Fischel et al., 2001).

Análises U-Pb SHRIMP em zircão de rocha metavulcânica félsica mostram idade de cristalização há $2115 \pm 23$ Ma. Dados de Sm-Nd mostram idade modelo 2.25 Ga e $\varepsilon_{\mathrm{Nd}}(\mathrm{t})=$ +3.15 , evidenciando caráter juvenil do magmatismo. Idades em zircão são discordantes e apresentam intercepto inferior em $524 \pm 83 \mathrm{Ma}$ (Fischel et al., 2001).

Grãos de zircão do Granito Jurubatuba também fornecem idades paleoproterozóicas, e datações U-Pb em SHRIMP indicam idade quase concordante em $2089 \pm 14$ Ma. Isótopos de Sm-Nd mostram idades $T_{\mathrm{DM}}$ de 2.3 a $2.42 \mathrm{Ga}$ e $\varepsilon_{\mathrm{Nd}}(\mathrm{t})=0.22$ a -0.58 (Fischel et al., 2001).

Lacerda Filho et al. (1991) sugerem que a sequência Silvânia e o Granito Jurubatuba são produto de granitogênese de arco de ilha.

\subsection{Características do Paleoproterozóico a oeste do Arco Magmático de Goiás}

A oeste do Arco Magmático de Goiás, no domínio da Faixa Araguaia, afloram rochas arqueanas e paleoproterozóicas interpretadas como seu embasamento (Arcanjo et al., 2013), 
embora dados sísmicos recentes sugiram que esse fragmento de crosta não seja o embasamento da Faixa Araguaia (Trindade, 2014).

Adjacentes ao Lineamento Transbrasiliano afloram ortognaisses paleoproterozóicos do Complexo Rio dos Mangues datados em $2065 \pm 3$ Ma por Pb-Pb TIMS em zircão (Arcanjo et al., 2013). Granulitos do complexo Porto Nacional são encontrados nas proximidades da cidade homônima e apresentam idades Pb-Pb TIMS em zircão entre 2112 e 2134 Ma (Gorayeb et al., 2000).

Saboia (2009) encontrou idade 2085,8 \pm 9,8 Ma para tufo félsico da Suíte Vulcânica Santa Rosa, e $2018 \pm 13$ Ma para o Granito do Carmo. Ambos afloram a norte da cidade de Monte do Carmo e apresentam valores de $\varepsilon_{\mathrm{Nd}}(\mathrm{t})$ positivos, com idades modelo variando de 2.11 a $2.17 \mathrm{Ga} .$.

É interessante notar que na Faixa Araguaia ocorre magmatismo máfico alcalino no fim do Mesoproterozóico (Arcanjo et al., 2013), possivelmente em consequência de evento tafrogenético. Esse evento pode ser reflexo da quebra de Rodínia. Na Faixa Brasília, ainda não foram descritas rochas dessa idade e natureza. 


\section{The NATIVIDAde BASEMENT: PETROGRAPHY AND MINERAL CHEMistry OF PAleoproterozoic GRANitiC ROCKS IN NORTHERN BRASÍLIA BELT}

\subsection{Introduction}

The Natividade basement is a small area within the Paleoproterozoic terrane in northern Brasília Belt. These rocks represent the belt's basement, where, from northern Goiás to southern Tocantins, a wide variety of granitic rocks is exposed. This ensemble of granites is interpreted as basement for being the sialic core over which sediments were deposited during middle-late Proterozoic.

Although these rocks form a continuous terrane, mild differences can be recognized among parts of the basement and smaller domains may be individualized. There is no previous work detailing the petrography of granites in this specific area and, in this paper, we characterize the suites around Natividade, in the state of Tocantins, to support future studies in the area.

\subsection{Geologic Overview}

In the basement, at least two different domains are recognized: (i) the CavalcanteArraias domain and (ii) the Almas-Conceição do Tocantins domain (Figure 3.1). The first encompasses peraluminous S-type granites intrusive in graphitic schists of the Ticunzal Formation (Botelho et al, 1999). The Almas-Conceição do Tocantins domain presents tonalite, trondhjemite and granodiorite intrusive in a volcano-sedimentary sequence named Riachão do Ouro group. This sequence contains mafic and ultramafic volcanic rocks, quartzite, phyllite and chemical sediments as chert, gondite and banded iron formation (Cruz \& Kuyumjian, 1998). The granitic assembly, characterized as TTG, may be divided in two suites: an amphibole bearing metaluminous one, and a biotite bearing peraluminous one (Cruz \& Kuyumjian, 1998).

Cavalcante-Arraias domain occupies the southern portion of the basement, whereas the Almas-Conceição do Tocantins domain is in its northeast region. There is no cartography between these two domains and it is unknown how one domain meets the other. 


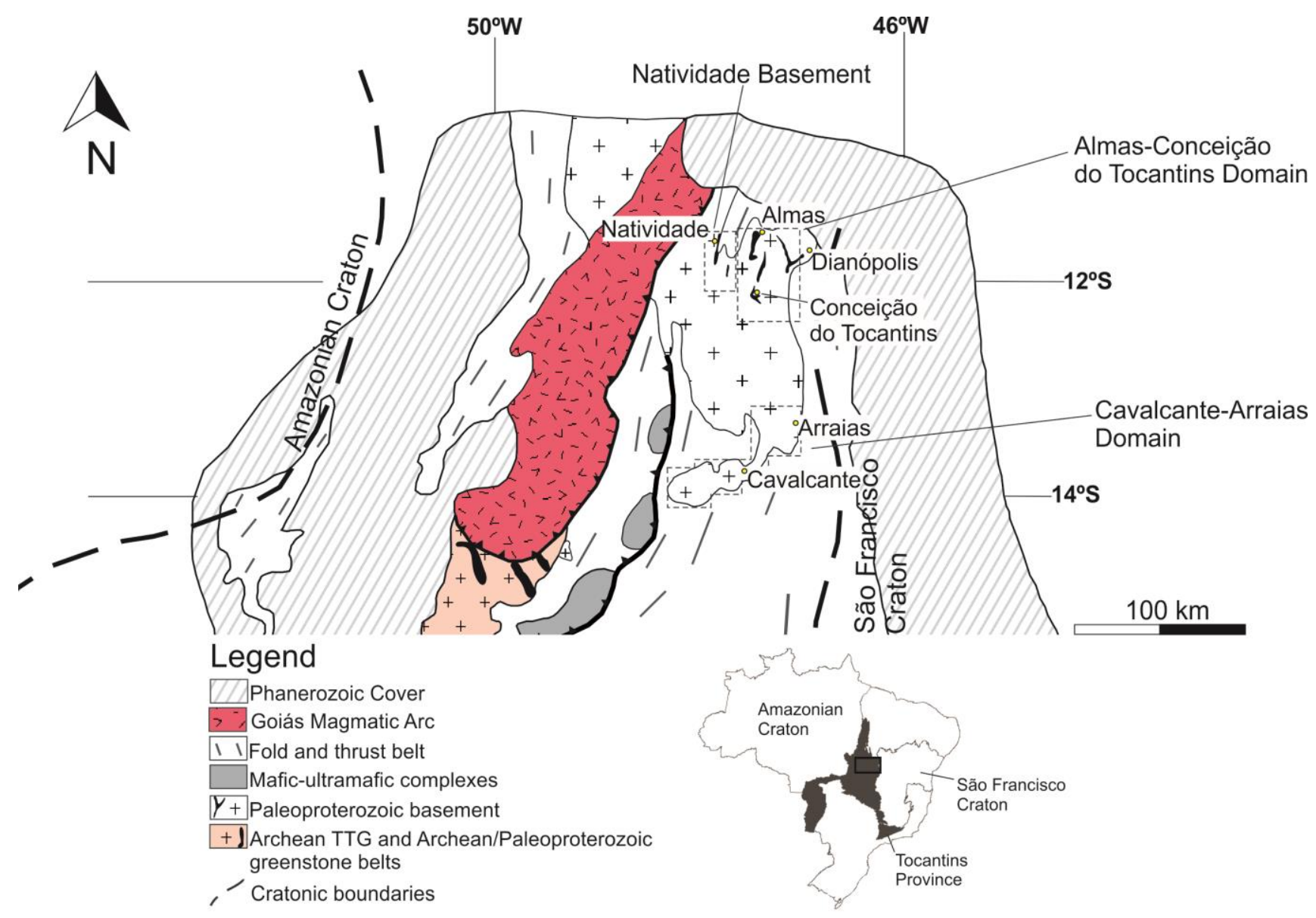

Figure 3.1: Domains in Northern Brasília Belt. Almas-Conceição do Tocantins, Cavalcante-Arrais domains and Natividade Basement (Modified after Pimentel et al., 2006; Oliveira et al., 2006).

Available U-Pb geochronological data indicate Aurumina suite crystallized between 2.12 and $2.17 \mathrm{Ga}$ (Botelho et al., 2006). Granitic rocks from the Almas-Conceição do Tocantins domain are dated by U-Pb in zircon at $2.22 \mathrm{Ga}$ (Cruz, 2001).

Natividade basement, in turn, crops out west of Almas-Conceição do Tocantins domain. Oliveira. (2012) mapped Natividade basement and divided granitic rocks in five units: (i) Rio do Moleque suite, (ii) Manuel Alves suite, (iii) Córrego Quati tonalite (iv) Xobó suite and (v) Príncipe granite, abbreviated as RM, MA, CQ, XS and PG, respectively (Figure 3.2). These units were individualized essentially by structural boundaries and geophysical signature, as deep weathering hampers cartography and conceals geologic contacts. The suites are intrusive in Água Suja sequence (Queiroz, 2001), a volcano-sedimentary sequence. Sediments from Natividade Group cover part of the basement. North from Príncipe Granite, a small area of extremely altered rocks was mapped as hydrothermalites. They have igneous protoliths, but its paragenesis is completely reequilibrated to a quartz-sericite-epidote-titanite association. 
Two metamorphic events are seen in basement rocks: the first, Paleoproterozoic, reached low amphibolite facies, not evident in granitic rocks, but seen in the paragenesis of basic rocks from volcano-sedimentary sequences. Presence of hornblende in basaltic rocks and the existence of gondite in Água Suja sequence are atributted to Paleoproterozoic metamorphism. Lima (2014) presented geochronological data for titanite grains from RM and Água Suja. His results show one group of magmatic grains at $2342 \pm 26 \mathrm{Ma}$ in RM and a group at $2153 \pm 25 \mathrm{Ma}$ in Água Suja sequence, interpreted as the age of metamorphic peak.

The second deformational event is the Brasiliano Orogeny, responsible for reequilibration in greenschist facies. Neoformation of white mica and epidote, plagioclase decalcification, quartz recrystallization and biotite chloritization seen in samples today record the effects of Neoproterozoic greenschist metamorphism.

Rocks do not present two distinct foliations, what is interpreted as a Brasiliano superimposed deformation in previous foliated rocks. Paleoproterozoic orogeny generated NNE-SSW foliation planes, dipping $40-60^{\circ}$ to the west. As Brasiliano structures have essentially the same direction, it probably appropriated Paleoproterozoic foliation planes, sometimes verticalizing them close to shear zones. Milonites with vertical $c$-foliation reveal dextral kinematics. South dipping planes are seen in CQ and MA, and are worth mentioning as they may reveal tectonic convergence other than classic E-W during Paleoproterozoic and Brasiliano orogenies. 


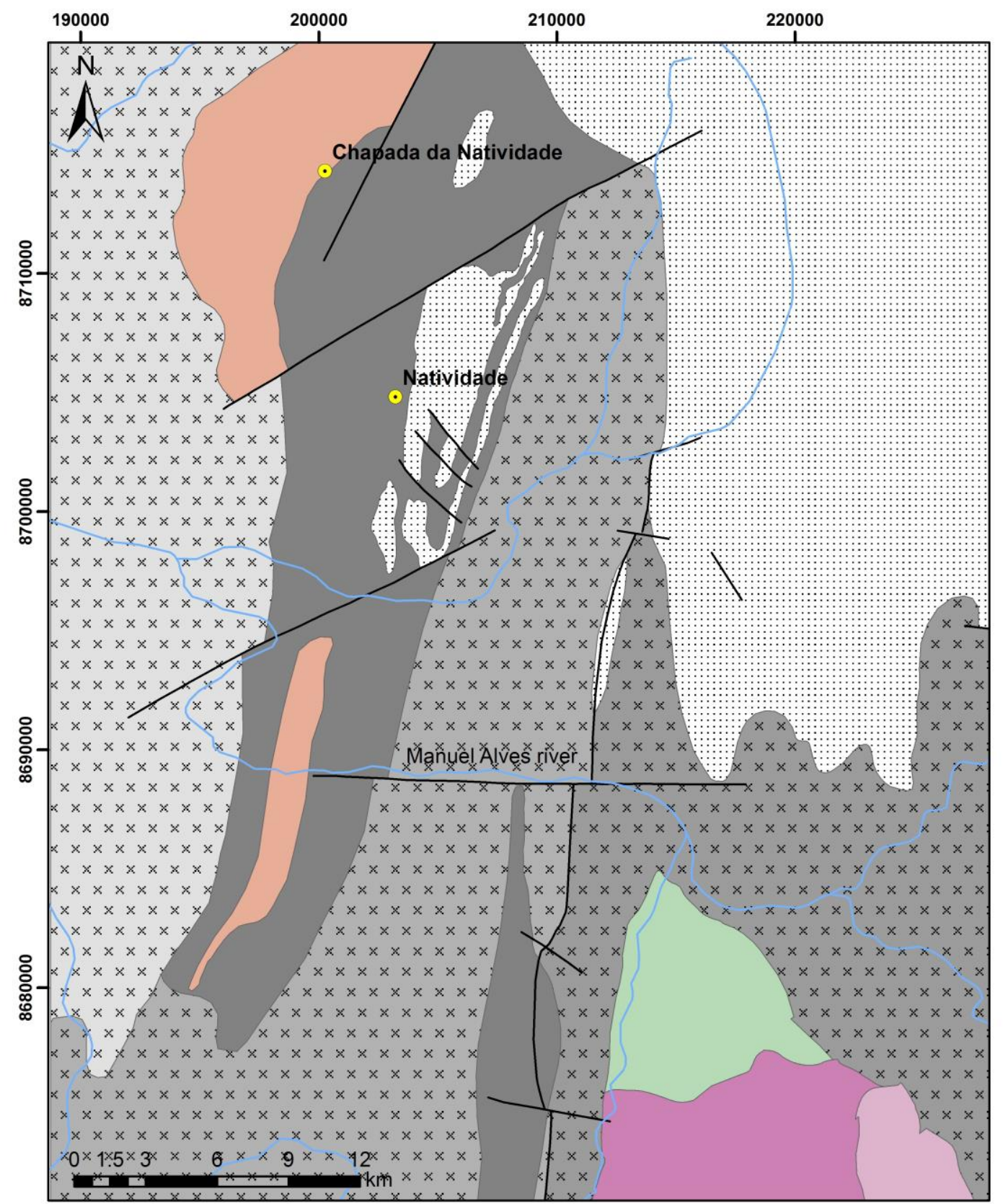

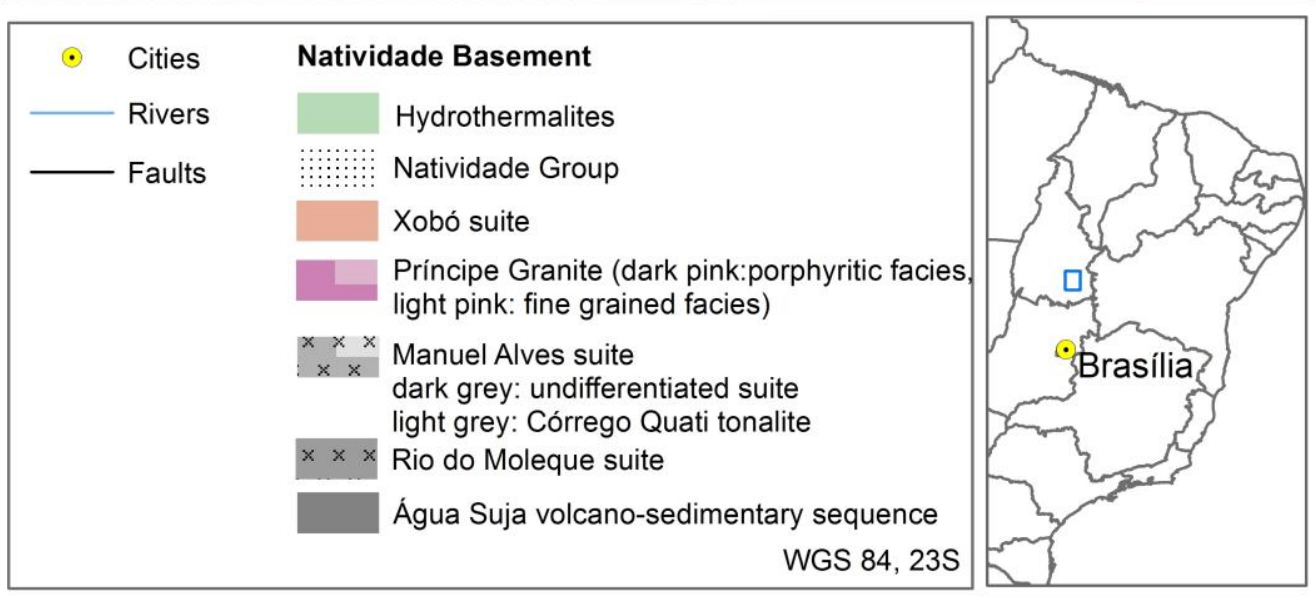

Figure 3.2: Geologic map from Natividade Basement (Oliveira, 2012). 


\subsection{Petrography of Natividade Basement}

Natividade basement is the chosen nomenclature for Paleoproterozoic rocks around Natividade and has no tectonic connotation. As mentioned, the five units described are:

\subsubsection{Rio do Moleque Suite}

Rio do Moleque suite is very homogeneous. Its tonalites are light grey, medium to coarse grained and have only biotite as mafic constituent. RM suite tonalites have quartz (30$40 \%)$, plagioclase $\mathrm{An}_{10}(30-35 \%)$ and biotite (10-20\%). K-feldspar is rare (<5\%). Plagioclase grains present variable degree of saussiritization (Figure 3.3a). Quartz is recrystallized, exhibits polygonal contacts and undulose extinction. Allanite and epidote are ubiquitous phases (Figure 3.3c, Figure 3.3d) as well as muscovite (Figure 3.3b) and sphene. Muscovite grains with comparable size to plagioclase and biotite are believed to be magmatic phases. Epidote and allanite grains are secondary phases.
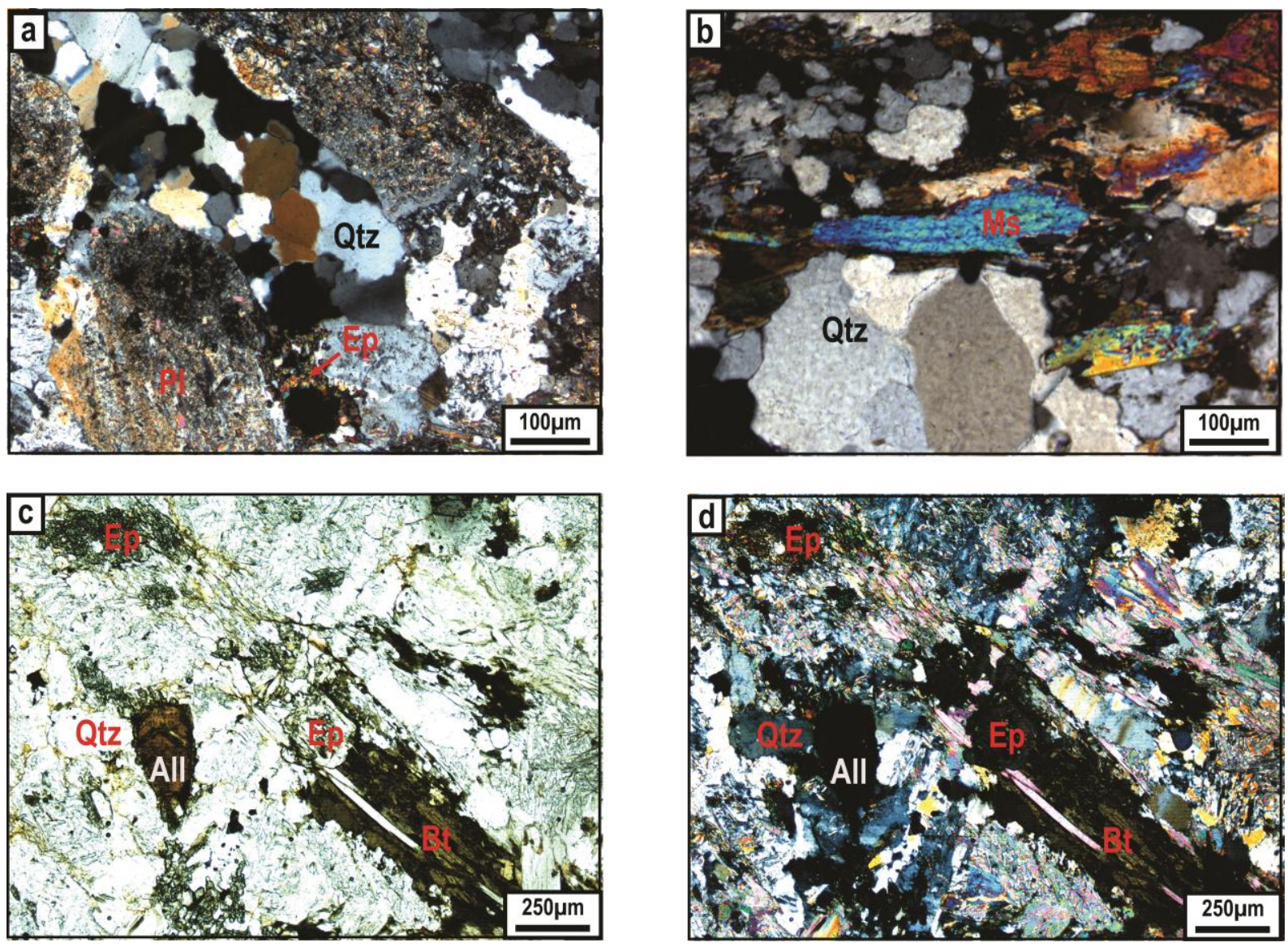

Figure 3.3: Photomicrography from tonalite sample NI-VIII-122 (RM suite). A) Recrystallyzed quartz, saussuritized plagioclase and neoformed epidote; B) Muscovite lamellae believed to be a magmatic phase; C and D) Neoformed grains of allanite and epidote. Greenish-brown biotite. (Qzt: quartz; Pl: plagioclase; Ep: epidote; Ms: muscovite; Bt: biotite; All: allanite). 
Greenish-brown biotite presents subhedral lamellae, forming a lepidoblastic texture in foliated samples. Plagioclase low content of $\mathrm{Ca}$ is interpreted as decalcification during alteration. Plagioclase original compositions probably were between andesine and oligoclase. In one sample from RM suite, albitization is evidenced by neoformed grains of albite. No pluton is identifiable in RM Suite because of the lack of outcrops.

\subsubsection{Manuel Alves Suite}

Manuel Alves suite resembles RM suite. It was individualized for the existence of a strike-slip fault between them, the Cruz das Almas Shear Zone. MA suite tonalites are more deformed than RM for outcropping in a strike-slip corridor. Samples from this suite are mesocratic, with biotite as the only mafic constituent. Tonalites have quartz (30-40\%), plagioclase from $\mathrm{An}_{8}$ to $\mathrm{An}_{12}(30-40 \%)$ and biotite (15-25\%). K-feldspar is minimum (0$10 \%$ ), but epidote and muscovite are common phases in most of the samples Apatite is a usual accessory mineral and in one sample, small graphite laths are present. As in RM suite, in MA suite plagioclase grains are anhedral and saussuritezed (Figure 3.4b). In two samples, garnet occurs in relatively large anhedral grains (Figure 3.4d), but is absent in other samples. Euhedral biotite lamellae have a reddish brown colour and clinozoisite is common in some samples (Figure 3.4c). Quartz is recrystallized and presents undulose extinction (Figure 3.4a). It is not possible to identify and map plutons in this suite, either. 

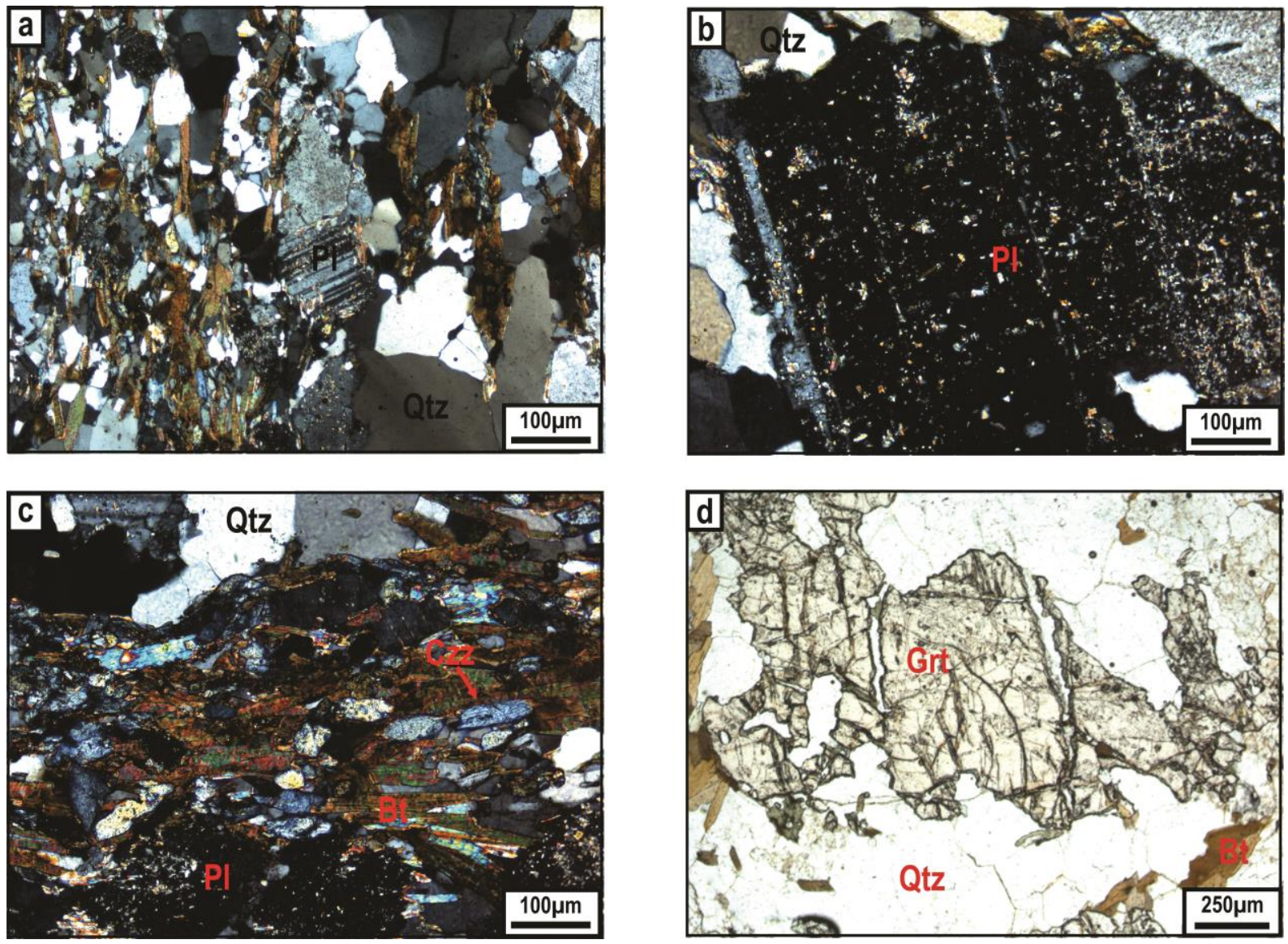

Figure 3.4: Photomicrography from tonalite sample NI-V-95 (:MA suite): A) Oriented biotite lamellae, recrystallized quartz and saussuritized plagioclase; B) Sericite formation in cleavage planes from plagioclase; C) Neoformed clinozoizite grains; D) Photomicrography from tonalite sample NI-V-90 (MA suite). Anhedral garnet grain. (Qzt: quartz; Pl: plagioclase; Czz: clinozoizite; Bt: biotite; Grt: garnet).

\subsubsection{Córrego Quati Tonalite}

We consider Córrego Quati tonalite part of the MA suite, but its homogeneous character and spatial continuity permitted its cartography. Macroscopically, CQ is almost white and biotite is the only mafic mineral. CQ is composed of quartz (30-40\%), plagioclase $\mathrm{An}_{10-20}(30 \%), \mathrm{K}$-feldspar (15\%) and biotite (10\%). Plagioclase decalcification is observed by low anorthite content in and by neoformation of epidote and zoisite. Epidote and allanite are probably secondary phases, and small euhedral garnet is present in a few samples (Figure 3.5). Apatite and titanite are accessory minerals. Biotite grains from CQ are euhedral reddishbrown lamellae and in some samples, biotite is partially chloritized. Tonalites from this unit are less hydrothermally altered, but are deformed close to minor shear zones. 

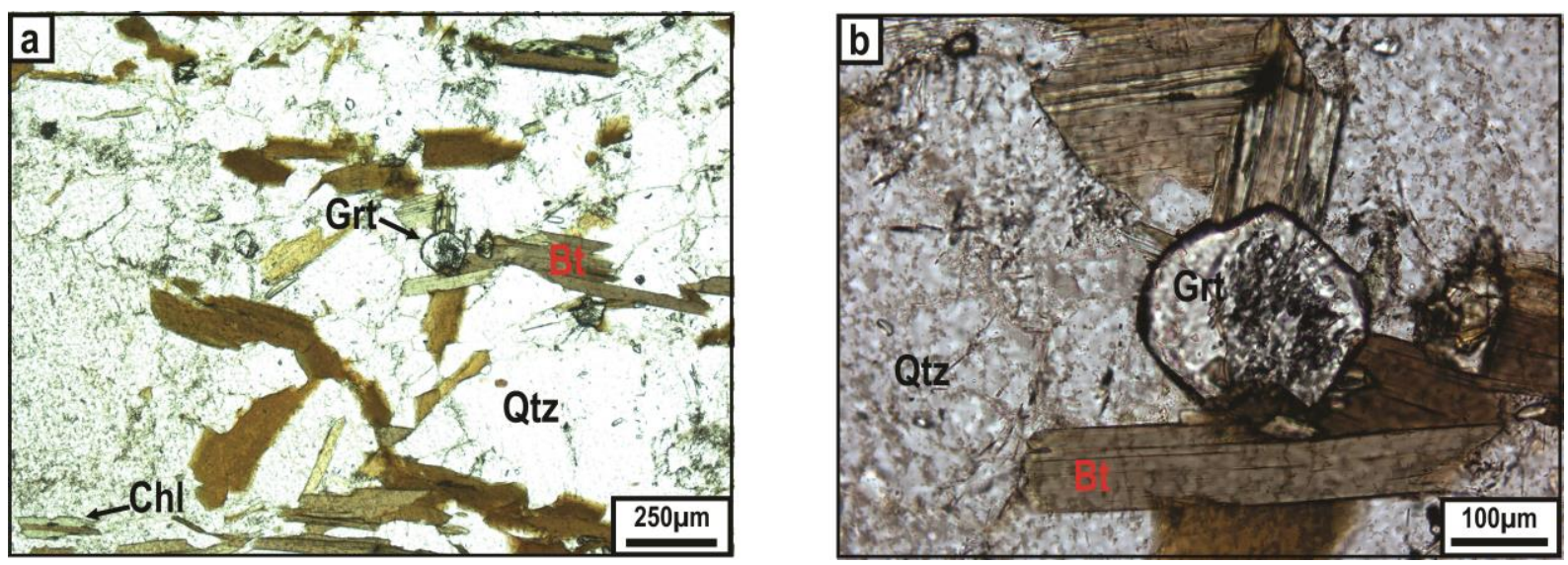

Figure 3.5: Photomicrography from tonalite sample NI-VII-38 (CQ tonalite): A) general texture of samples from CQ tonalite; B) Euhedral garnet grain. (Qzt: quartz; Bt: biotite; Grt: garnet; Chl: chlorite).

\subsubsection{Xobó Suite and Príncipe Granite}

Xobó suite crops out in the north-western part of the area, while Príncipe Granite (Figure 3.6) is an intrusive pluton in the southeast. In contrast with previous described units, both have granitic composition. They tend to be porphyrytic, and have quartz (20-25\%), plagioclase An10 (25-30\%), K-Feldspar (20-25\%), biotite (20\%), garnet and muscovite (sum $15 \%$ ). Príncipe Granite plagioclase grains are sericitized, quartz is recrystallized, K-feldspar is microcline and biotite has a brown colour. Allanite and epidote are common secondary phases. Xobó suite comprises large pegmatitic bodies that hamper sampling. Plagioclase grains from Xobó suite are more preserved, but quartz grains are recrystallized (Figure 3.7Figure 3.6). In Xobó suite, some samples exhibit sagenitic biotite. Corrêa (2014) presents extensive mineral chemistry analysis for Príncipe Granite, and in this paper, data for Xobó suite are shown. Príncipe Granite muscovite grains preserve magmatic composition (Corrêa, 2014). 

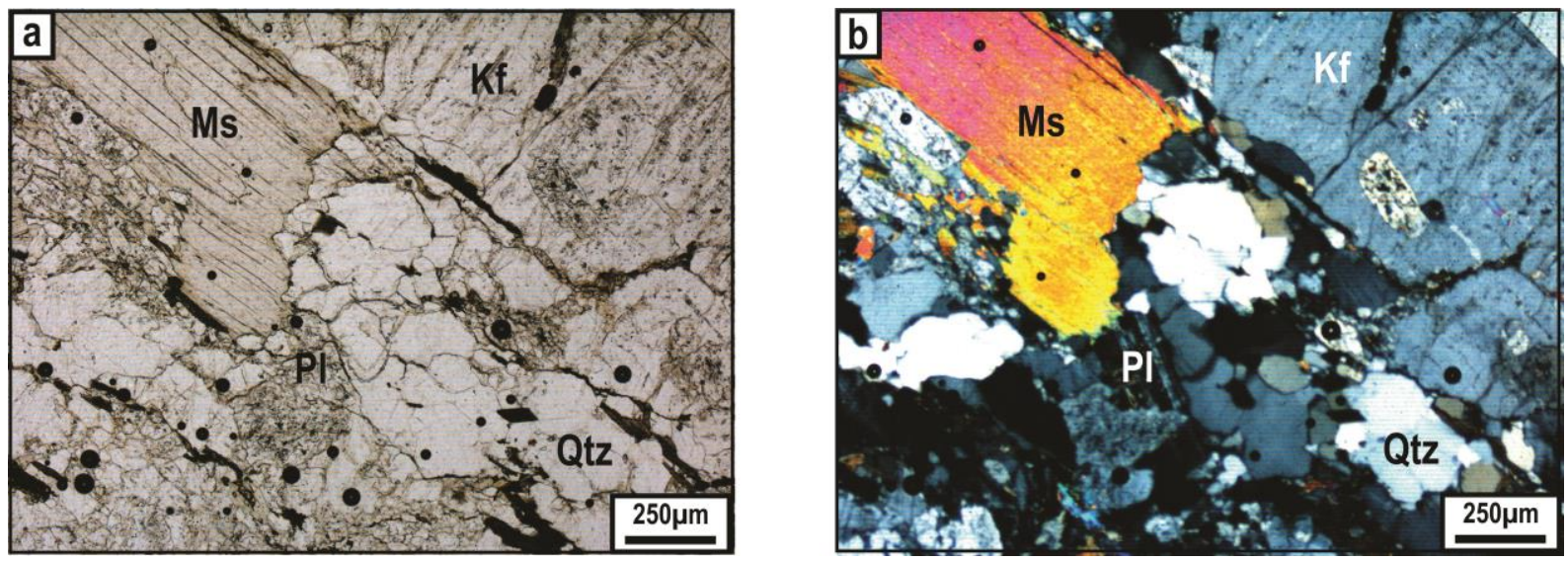

Figure 3.6: Photomicrography from granite sample NI-X-104 (Príncipe Granite). A and B)Muscovite grain of magmatic composition (Corrêa, 2014), recrystallized quartz, small euhedric plagiocase grain and large microcline grain. (Qzt: quartz; Pl: plagioclase; Ms: muscovite; Kf: microcline).
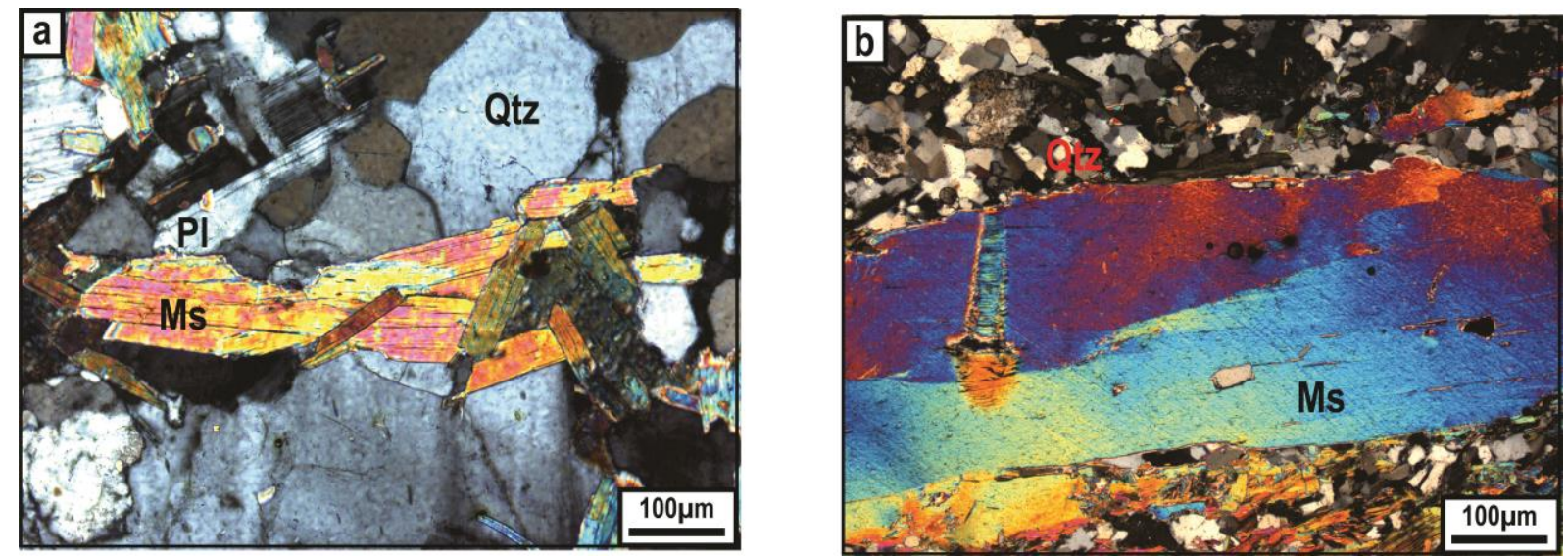

Figure 3.7: A) Photomicrography from granite sample NI-I-50 (Xobó suite). Muscovite is comparable in size to plagioclase grains and is considered primary. Plagioclase grains are well preserved and quartz is recrystallized; B) Photomicrography from granite sample 1.1 (Xobó suite). This rock crops out close to a shear zone. Quartz is completely recrystallized and large muscovite is neoformed (as shown in the next topic), but smaller grains are believed to be magmatic.

\subsubsection{Modal classification}

When plotted in Streckeisen diagram, samples from RM, MA and CQ belong to tonalite and granodiorite fields. XS and PG are monzogranites (Figure 3.8). 


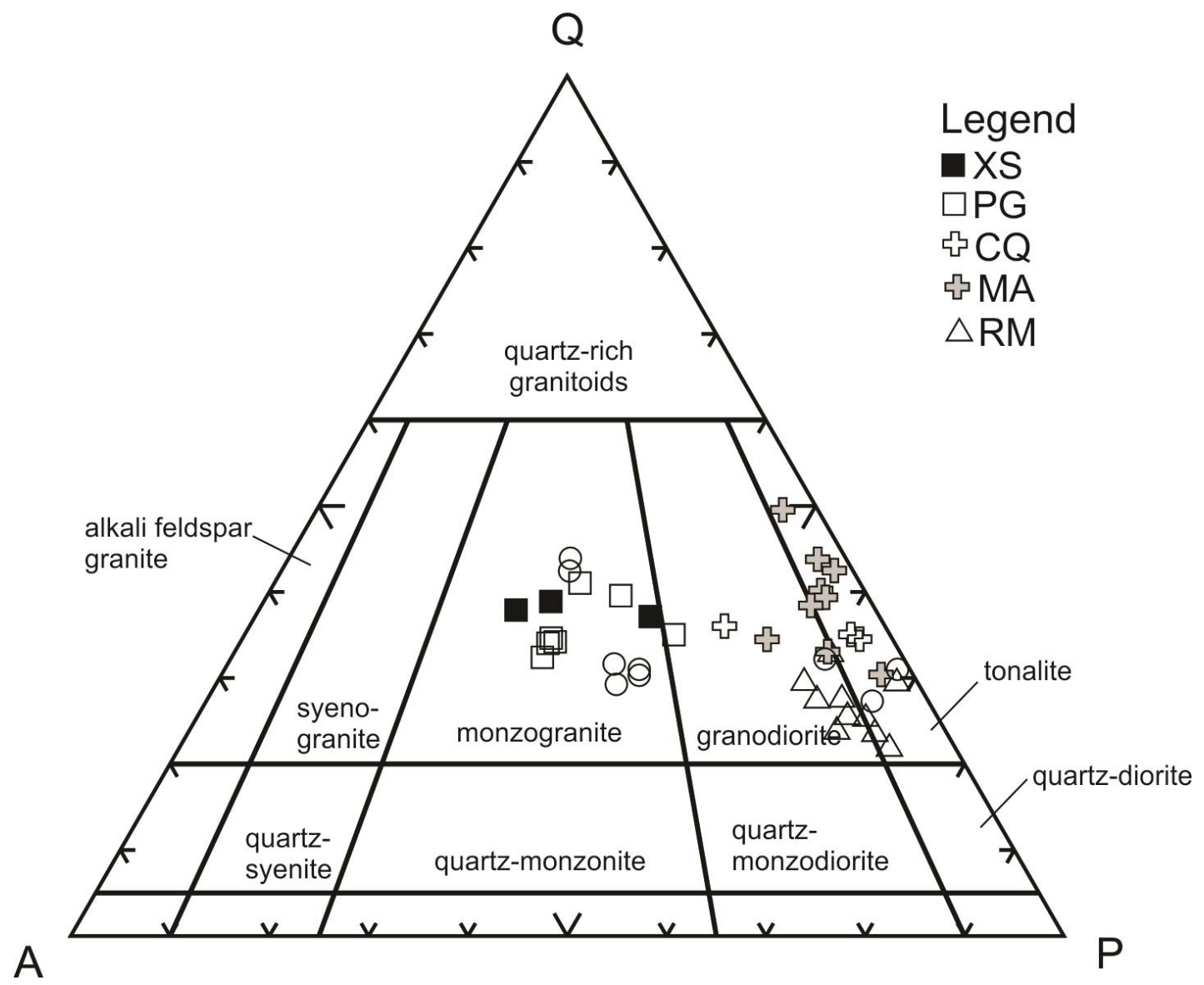

Figure 3.8: QAP diagram (Streckeisen, 1976) of Natividade Basement.

\subsection{Mineral Chemistry}

Electron microprobe analysis was used to investigate muscovite, biotite and garnet compositions in order to identify whether these minerals are magmatic or secondary phases. This distinction is important as it provides information about alumina saturation index, oxidation state and magma composition. Chlorite chemistry was also analysed in an attempt to estimate how it formed.

\subsubsection{Analytical procedures}

Mineral analyses were obtained by wavelength-dispersive X-ray spectrometry (Fava, 2000) for 13 elements (Na, Mg, F, Si, Al, K, Ca, Cl, Ti, Mn, V, Fe e Ba) using JEOL JXA8230 Electron Microprobe from the Electron Microprobe Laboratory in the Institute of Geosciences of the University of Brasília. Beam operating conditions were $20 \mathrm{kV}$ and $20 \mathrm{nA}$. Thin sections were polished and metalized with a $250 \AA$ A thick carbon film. 


\subsubsection{Muscovite}

Samples from RM, MA e X suites had muscovite grains analysed. As the purpose of this investigation is to certify their magmatic composition, chosen grains were the relatively coarse, subhedral to euhedral and not enclosed by minerals from which muscovite might have formed from alteration.

In terms of $\mathrm{Ti}, \mathrm{Mg}$ and $\mathrm{Na}$, most grains have primary composition (Figure 3.9) with relatively high contents of $\mathrm{Ti}$, as expected for magmatic muscovite, once at higher temperatures, Ti solubility is lower (Anderson \& Rowley, 1980).

In Figure 3.10b, muscovite with $\mathrm{TiO}_{2}>0.9 \%$ from MA and $\mathrm{RM}$ displays undoubtedly primary composition, but other grains have a more discrete enrichment in $\mathrm{TiO}_{2}(0.4$ to $0.6 \%)$ and are interpreted as reequilibrated or neoformed grains.

Some grains, all from Xobó suite, have low Ti, and high Na content (Figure 3.9 and Figure 3.10b). This can be a result of sodic alteration. As albitization is described in RM suite and the analysed sample from Xobó suite is from a hydrothermally altered shear zone, this Na-rich muscovite is more likely due to alteration that led to neoformation of grains. This assumption is sustained by low contents of $\mathrm{K}$ in these grains, possibly as consequence of $\mathrm{K}$ loss in fluid (Figure 3.10a), and by the coexistence of Ti rich muscovite in the same sample (Figure 3.9). Data suggest there are two generations of muscovite and that these high Ti grains are probably the primary ones.

From this analysis, even if some muscovite grains are reequilibrated or neoformed, the three suites have muscovite of magmatic composition coexisting with biotite. 


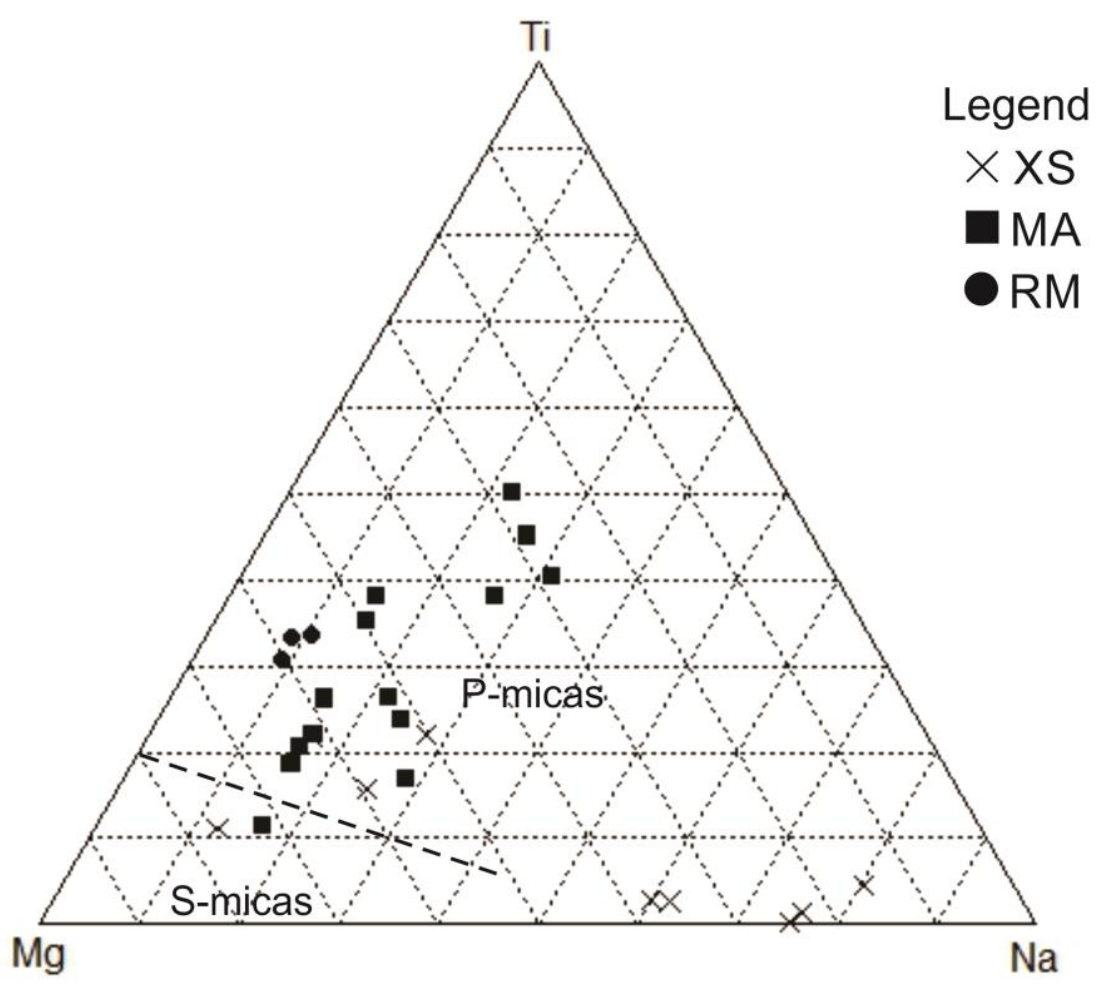

Figure 3.9: Compositions of analysed muscovite grains in terms of $\mathrm{Ti}, \mathrm{Mg}$ and $\mathrm{Na}$. The dashed line is the approximate division of primary and secondary mica domains after Miller et al., 1981.
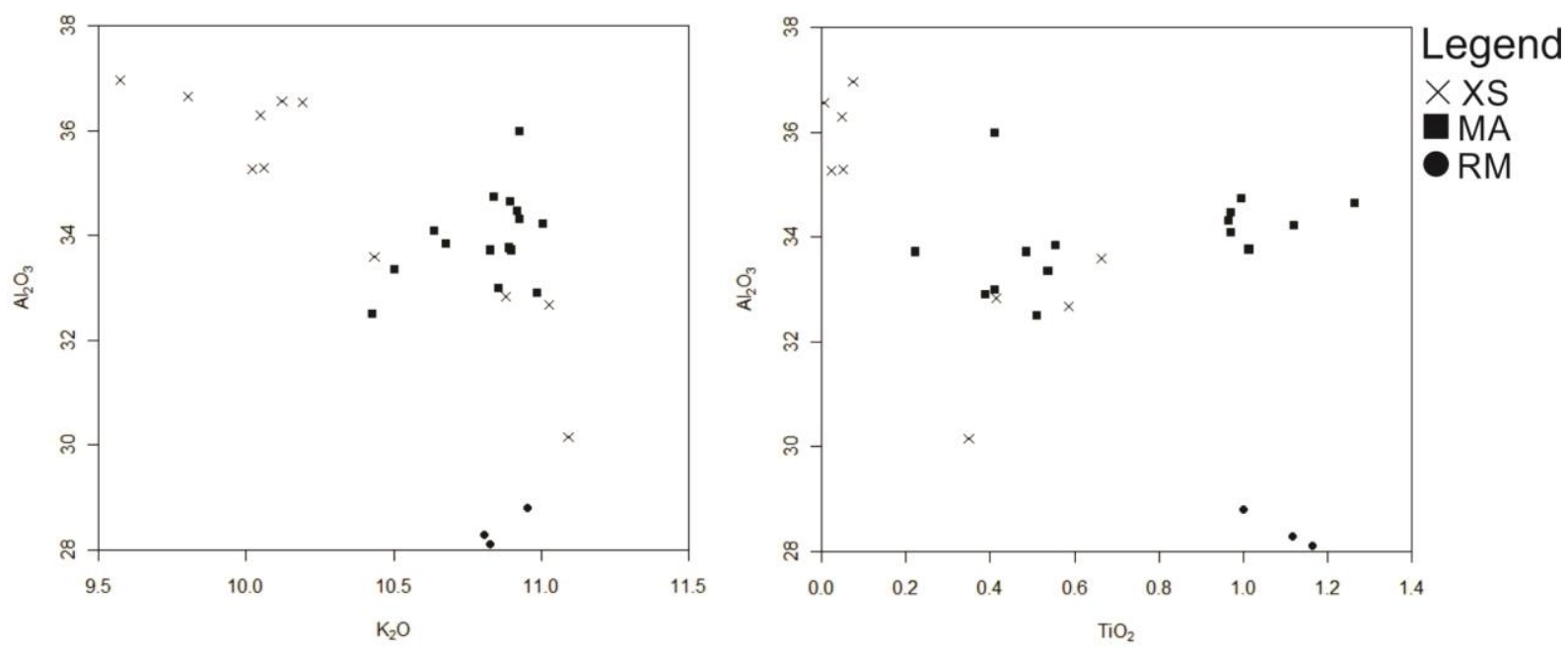

Figure 3.10: a. $\mathrm{K}_{2} \mathrm{O}$ vs $\mathrm{Al}_{2} \mathrm{O}_{3}$ for muscovite. Note Xobó Suite has muscovite grains with low $\mathrm{K}_{2} \mathrm{O}$ and with normal $\mathrm{K}_{2} \mathrm{O}$. b. $\mathrm{TiO}_{2}$ vs $\mathrm{Al}_{2} \mathrm{O}_{3}$ for muscovite. Note high $\mathrm{TiO}_{2}$ grains and Xobó suite's low $\mathrm{TiO}_{2}$ grains.

\subsubsection{Garnet}

Analysed garnet grains are from MA suite: one sample is from CQ tonalite and the other two are tonalites from undifferentiated Manuel Alves suite. Garnet from all samples has almandine as its main constituent, according to calculation based on 12 oxygens (Table 3.7). 
All analysed grains plot within the field of magmatic garnet composition (Figure 3.11) after Miller and Stoddard (1981), where Mn, Mg and Fe are considered. These authors suggest $\mathrm{Mn}$ is an important controlling factor in garnet formation as experimental studies demonstrate high Mn enhances stability of garnet in magmas. Goldschmidt (1954) shows that $\mathrm{Mn} /(\mathrm{Mg}+\mathrm{Fe})$ generally increases with igneous differentiation, as a result from crystal fractionation. Aside from garnet, $\mathrm{Mn}$ is not a principal constituent of any igneous silicate and Mn-enrichment may be a result of liquid state differentiation. Thus, spessartine-rich garnet is probably formed in relatively evolved magmas with high $\mathrm{Al}$ and low $\mathrm{Ti}$ contents, otherwise, Mn would be incorporated in ilmenite (Czamanske \& Mihálik, 1972).

Despite belonging to the field of magmatic garnet composition after Miller \& Stoddard (1981), this classification does not consider garnet Ca content. When we compare Miller \& Stoddard magmatic garnet to our analyses, we observe our grains are richer in Ca.

In Figure 3.12, another classification does consider $\mathrm{Ca}$ content. In this diagram, it is clear that garnet grains from Natividade basement are significantly different from garnet described as magmatic by Miller \& Stoddard (1981).

Thus, garnet grains form Natividade may not be magmatic phases, but metamorphic neoformed crystals. Being metamorphic, they could evince the amphibolite facies Paleoproterozoic metamorphism.

It is important to notice grains from CQ tonalite present the highest contents of $\mathrm{Mn}$, when compared to the other grains. Garnet from CQ occurs as euhedral small crystals and further research is necessary to verify if these grains could be magmatic phases, different from Miller \& Stoddard garnet grains, but also magmatic. 


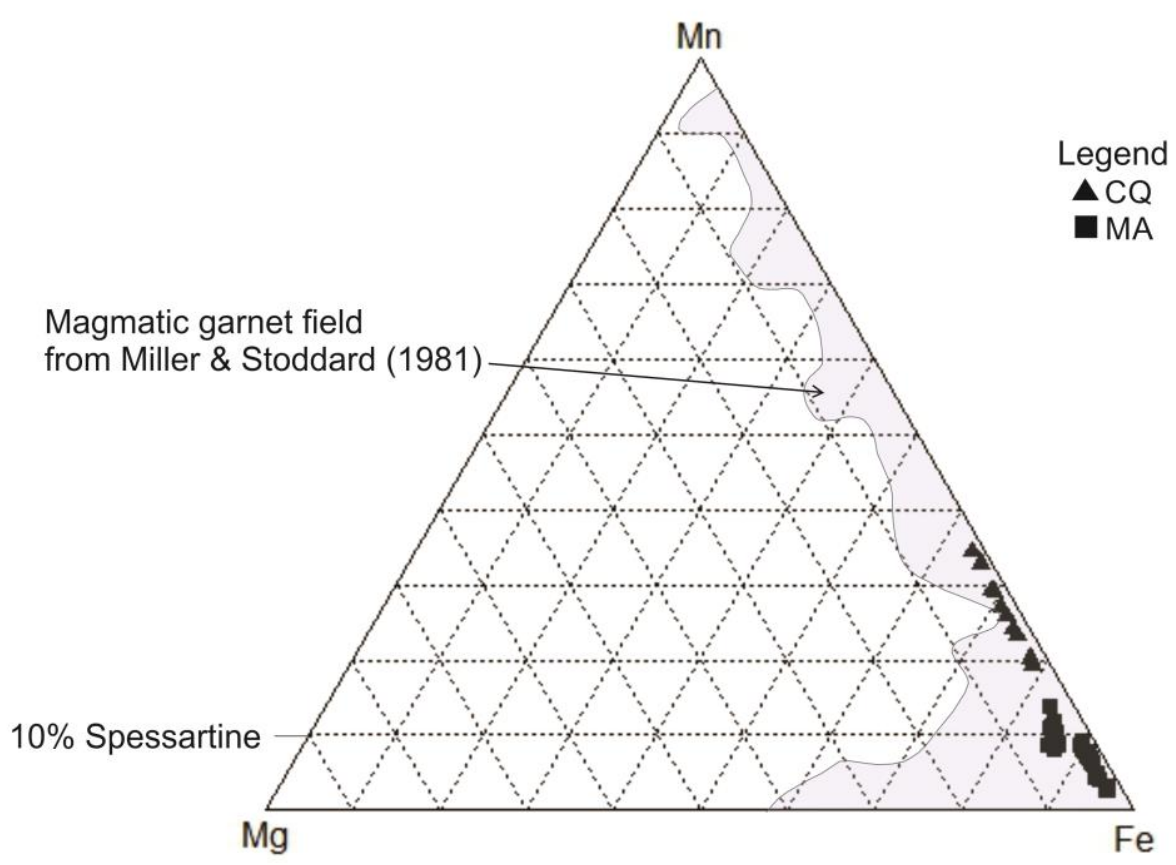

Figure 3.11: Garnet composition in terms of $\mathrm{Mg}, \mathrm{Mn}$ and $\mathrm{Fe}$ (atomic proportions). Grey area corresponds to magmatic garnet field delimited by Miller \& Stoddard (1981).

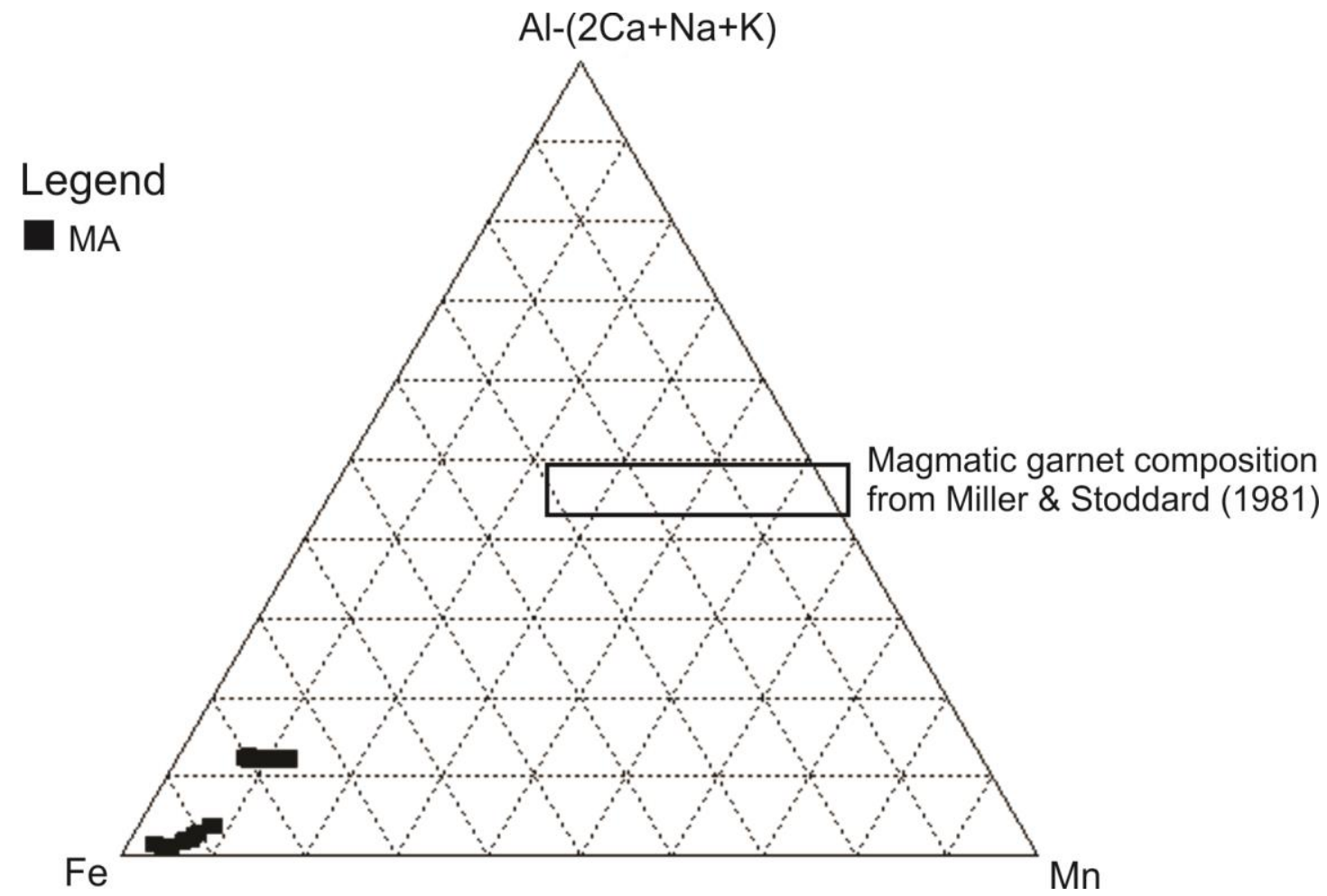

Figure 3.12: Garnet composition in terms of $\mathrm{Fe}, \mathrm{Al}-(2 \mathrm{Ca}+\mathrm{Na}+\mathrm{K})$ and $\mathrm{Mn}$ (atomic proportions). Rectangular area corresponds to composition of garnet described as magmatic by Miller \& Stoddard (1981). 

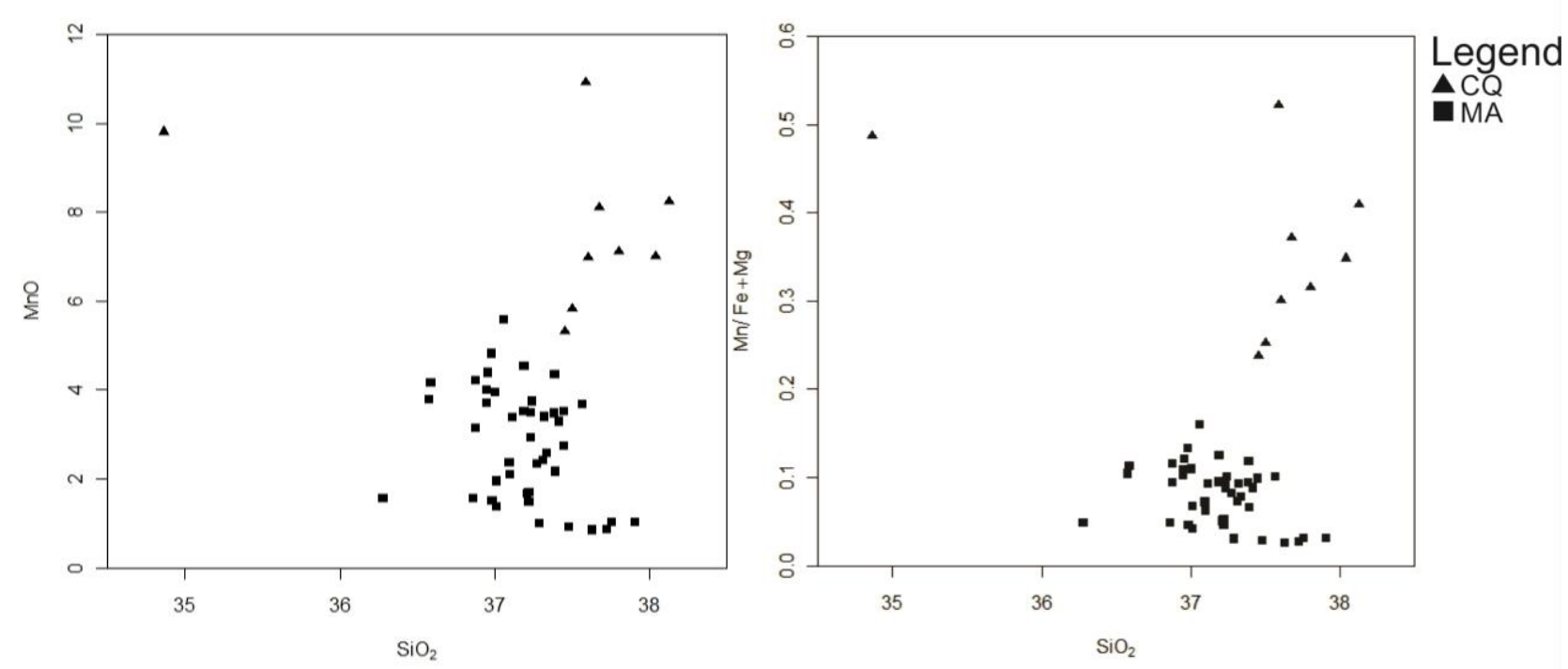

Figure 3.13: A) $\mathrm{SiO}_{2}$ vs $\mathrm{MnO}$; B) $\mathrm{SiO}_{2}$ vs $\mathrm{Mn} / \mathrm{Fe}+\mathrm{Mg}$. CQ tonalite comprises garnet grains with the highest $\mathrm{MnO}$ content.

\subsubsection{Biotite}

Biotite is a mafic constituent common to every unit. All the suites are poor in other mafics, and in just four of the forty thins sections studied, ilmentite or magnetite is seen. Sulphides, when present, are secondary phases in highly altered outcrops close to shear zones responsible for minor gold occurences.

Analyses were taken in coarse grains of biotite, crystallized from the magma, and not in rims of biotite surrounding other minerals, as the purpose of the analysis is to verify if the original magmatic grains preserve their compositions. Another important issue concerning biotite composition is whether it is possible to infer the oxidation state of the magma. But, since our analysis does not differentiate $\mathrm{Fe}^{2+}$ from $\mathrm{Fe}^{3+}$, our classification is empiric, based on colour and paragenesis.

Using the classification from Nachit et al. (2005), biotite grains plot primarily in the domain of reequilibrated biotite composition (Figure 3.14). This happens because biotite loses $\mathrm{Ti}$ as it reequilibrates to lower temperatures. During magma cooling and crystallization, Ti is expelled from biotite crystal lattice and crystallizes as rutile \pm ilmenite \pm titanite inclusions, or even as leucoxene. 


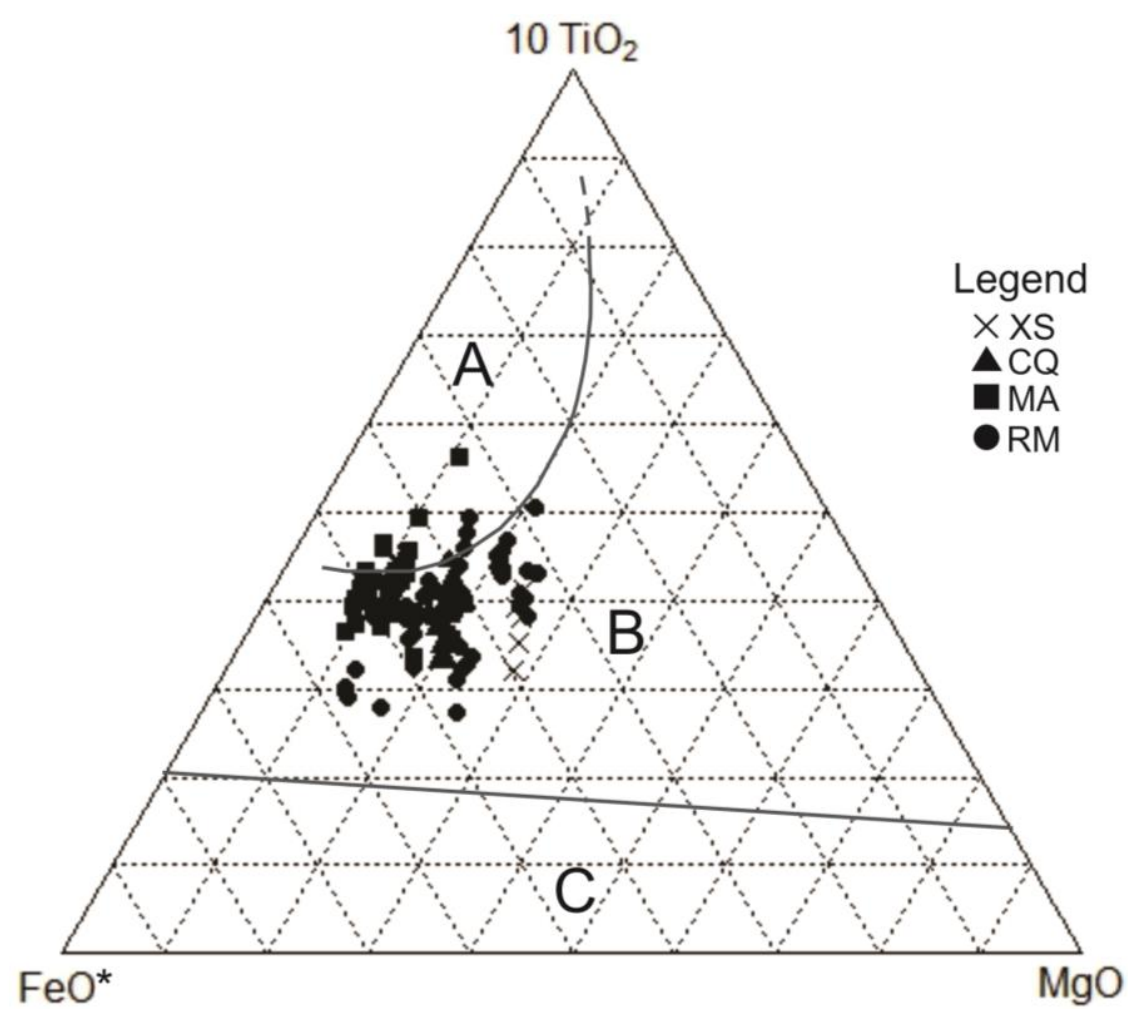

Figure 3.14: Biotite classification after Nachit et al., 2005. A: Domain of primary magmatic biotite. B: Domain of reequilibrated biotite. C: Domain of neoformed biotite.

Biotite grains from CQ tonalite, XS and MA suite have a reddish brown colour, while bitote from RM suite has a greenish brown tone. Ishihara (1977) points out biotite colour as one indicator of oxygen fugacity in magma, but the absence of other indicators makes it a weak determinant in our study. Nevertheless, reddish brown biotite is rich in Fe, Ti-bearing, has low $\mathrm{Fe}^{3+} /\left(\mathrm{Fe}^{2+}+\mathrm{Fe}^{3+}\right)$ and is common in reduced, generally peraluminous granitic rocks. Greenish brown biotite is $\mathrm{Mg}$ rich, has high $\mathrm{Fe}^{3+} /\left(\mathrm{Fe}^{2+}+\mathrm{Fe}^{3+}\right)$ and occurs more commonly in oxidized metaluminous granitic rocks (Lalonde \& Bernard, 1993).

Ti does not show a clear trend of enrichment in any suite (Figure 3.15), probably because $\mathrm{Ti}$ was expelled from biotite crystal lattice at lower temperatures. Meanwhile, $\mathrm{MnO}$ in biotite tends to present a positive correlation with $\mathrm{SiO}_{2}$ (Figure 3.15), the same way $\mathrm{Mg} / \mathrm{Fe}$ does (Figure 3.16), if we consider analyses from all suites. High $\mathrm{Mg}$ and $\mathrm{Mn}$ contents are more visible in RM suite, where biotite is greenish brown. It is possible that these biotite compositions in RM suite reveal a little evolved character of this suite.

$\mathrm{SiO}_{2}$ vs $\mathrm{Al}_{2} \mathrm{O}_{3}$ graphic shows almost horizontal alignments in each sample, revealing little variation in $\mathrm{Al}$ content (Figure 3.16a). $\mathrm{RM}$ samples have the lowest $\mathrm{Al}_{2} \mathrm{O}_{3}$ contents. 

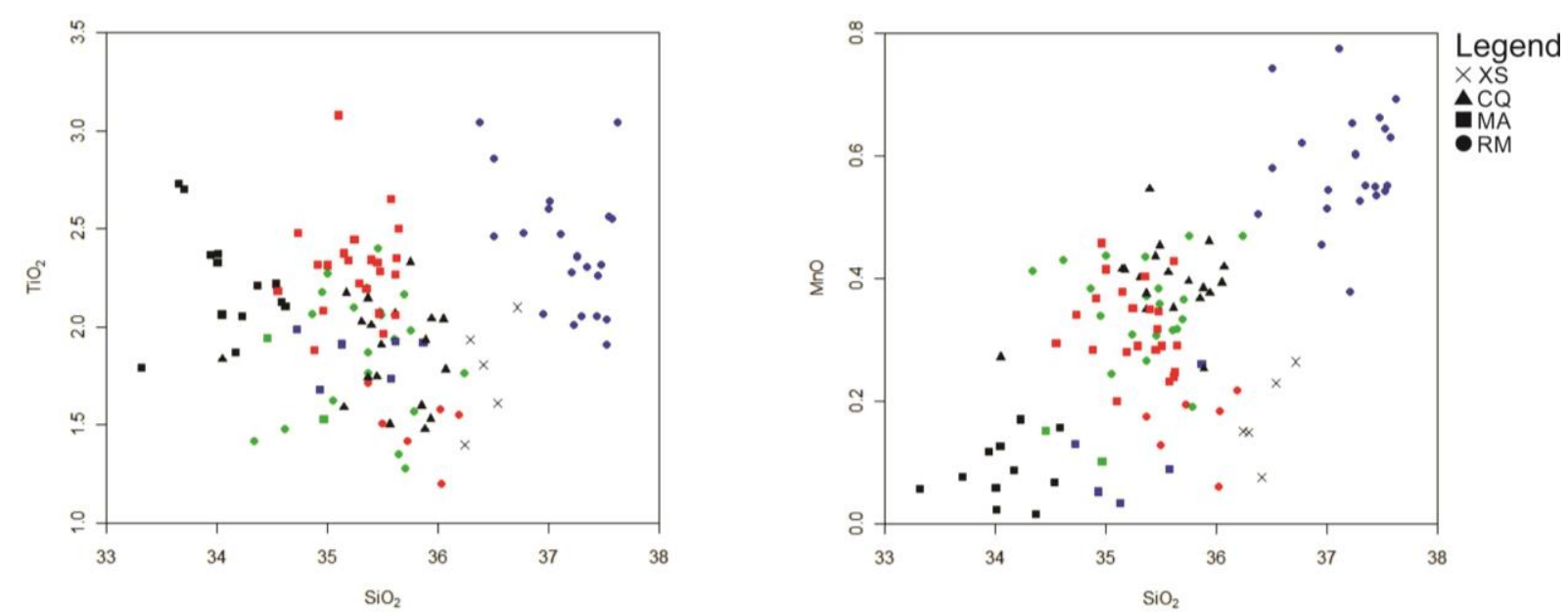

Figure 3.15: Biotite composition of XS, CQ, Ma and RM. $\mathrm{SiO}_{2} \mathrm{vs}_{\mathrm{TiO}_{2}}$ and $\mathrm{SiO}_{2}$ vs $\mathrm{MnO}$. Colours represent biotite analysis in grains from the same sample.
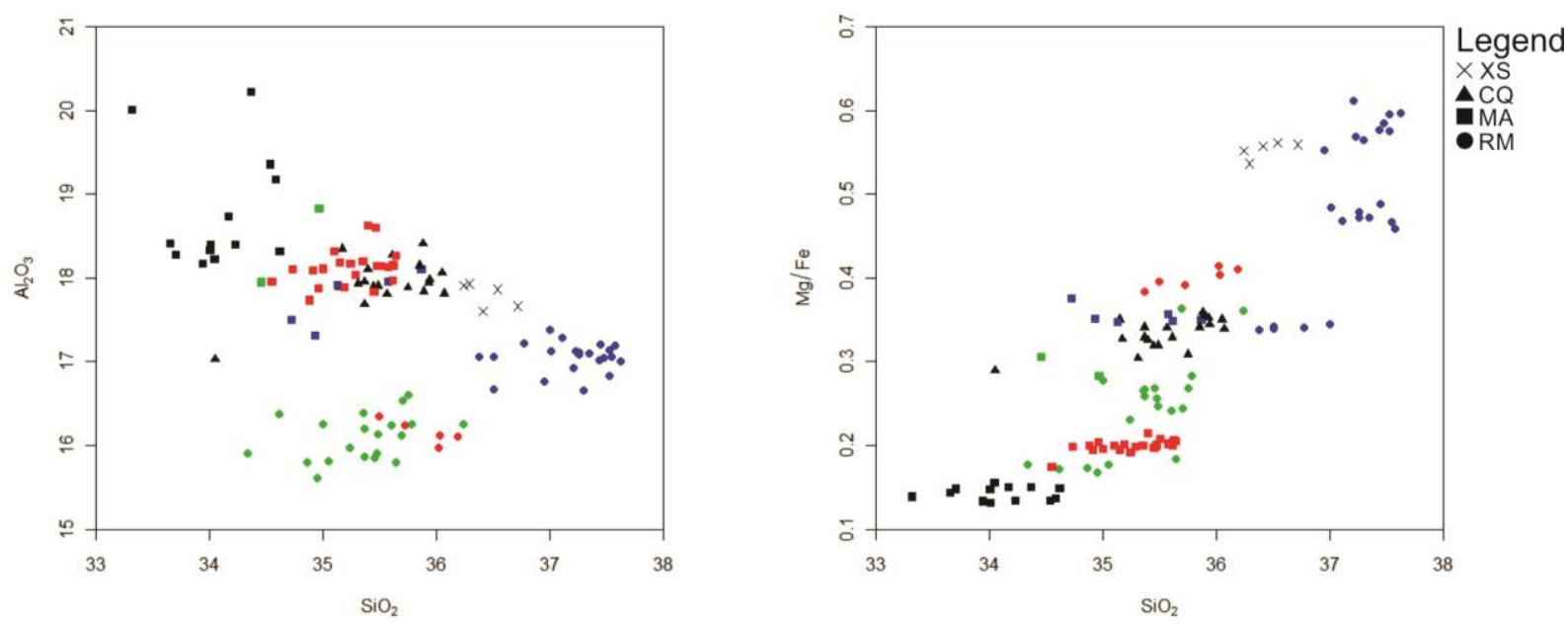

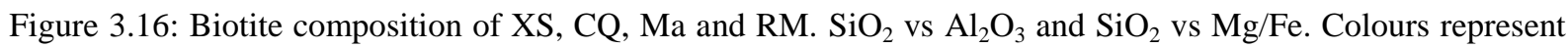
biotite analysis in grains from the same sample.

$\mathrm{XS}$ biotite is surprisingly rich in $\mathrm{Mg}$, relative to Fe (Figure 3.16b). As mentioned in muscovite results, the analysed sample from Xobó suite crops out in the middle of a shear zone, where there is a gold mine. It is possible that mineralizing fluids percolated through the shear zone and affected biotite composition. Thus, high-Mg biotite does not reflect original magmatic compostion. Samples from other units, although reequilibrated, still reflect magmatic composition.

\subsubsection{Chlorite}

Chlorite grains analysed are from three rock samples, two from MA suite and one from CQ tonalite. MA grains have a relatively homogeneous behaviour in Mn content, showing 0.15 to 0.40 wt. $\%$ of $\mathrm{MnO}$, while chlorite from CQ tonalite has 0.6 to 0.8 wt. $\%$ of $\mathrm{MnO}$ (Figure 3.17). 
Based on 28 oxygen and assuming full site occupancy for $\mathrm{Fe}^{2+} / \mathrm{Fe}^{3+}$ and $\mathrm{OH}$ calculation, chlorite chemistry indicates ripidolite composition, given the high contents of $\mathrm{Fe}$ and intermediate contents of $\mathrm{Mg}$ (Table 3.17: Chlorite). High contents of Fe reflect biotite from which they formed.
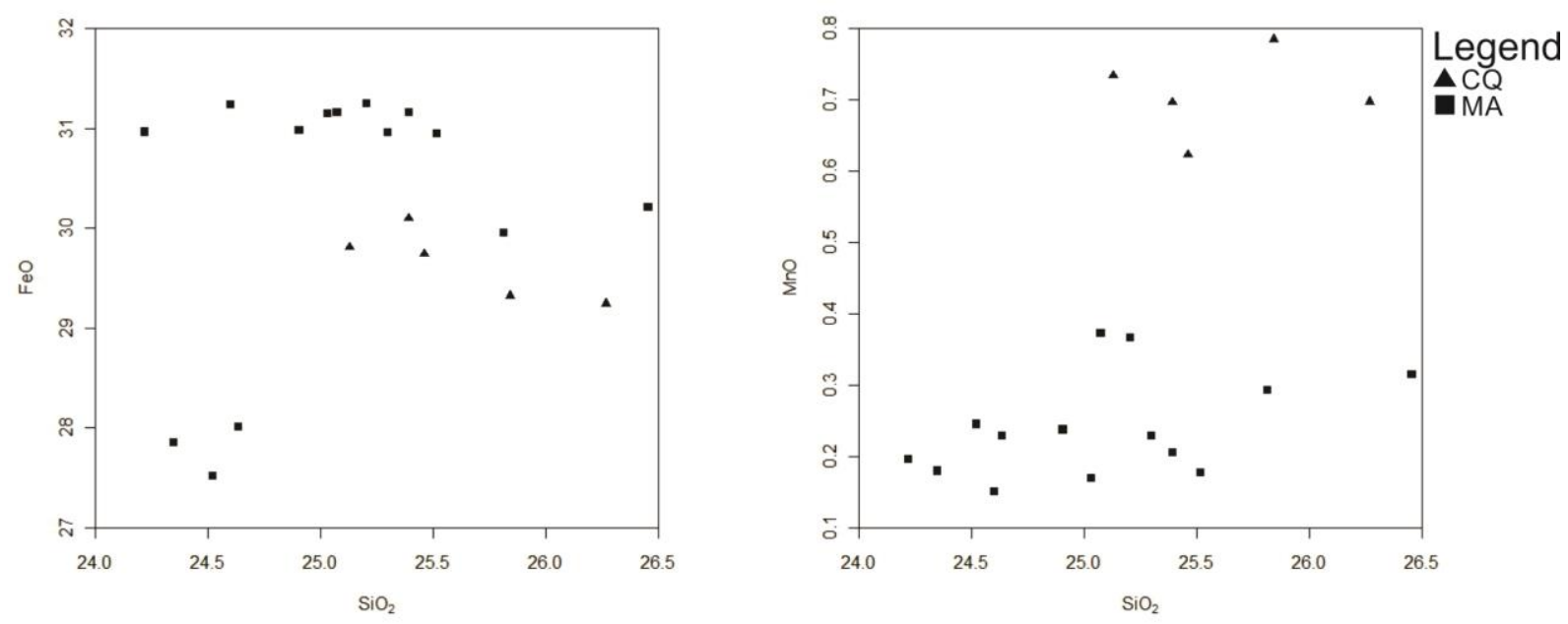

Figure 3.17: Chlorite composition of CQ and $\mathrm{MA}$. $\mathrm{SiO}_{2}$ vs $\mathrm{FeO}$ and $\mathrm{SiO} 2$ vs $\mathrm{MnO}$.

\subsection{Conclusions}

Although affected by Brasiliano and Paleoproterozoic orogenies, the three studied suites preserve muscovite of magmatic composition. Coexistence of magmatic muscovite and biotite in Xobó, Manuel Alves and Rio do Moleque suites is a strong argument to support their peraluminous character, but whole rock chemistry is essencial to confirm it.

Garnet does not have magmatic composition, but may be evidence Paleoproterozoic metamorphism affected granitic rocks.

Biotite chemistry shows loss of $\mathrm{Ti}$, due to $\mathrm{Ti}$ expulsion from crystal lattice at lower temperatures and chlorite composition reflects biotite from which they formed.

When biotite analyses from all suites are plotted together and compared, a trend that positively correlates $\mathrm{Mg} / \mathrm{Fe}$ with $\mathrm{SiO}_{2}$ and $\mathrm{Mg}$ with $\mathrm{SiO}_{2}$ is seen. Whole rock chemistry is fundamental to better understand relation between suites.

Further geochemical and geochronological analyses are needed to investigate what is the nature of this magmatism, but for now, it is possible to state that these Paleoproterozoic rocks preserved muscovite, biotite and garnet with magmatic composition through orogenetic events. Data presented in this paper will support future studies in this area. 


\subsection{Appendix}

Table 3.1: Muscovite composition (1/2)

\begin{tabular}{|c|c|c|c|c|c|c|c|c|c|c|c|c|c|c|}
\hline Sample & 1.1 & 1.1 & 1.1 & 1.1 & 1.1 & 1.1 & 1.1 & 1.1 & 1.1 & 1.1 & 1.1 & NI-V-99 & NI-V-99 & NI-V-99 \\
\hline Unit & $\begin{array}{c}\text { XS } \\
\text { granite }\end{array}$ & $\begin{array}{c}\text { XS } \\
\text { granite }\end{array}$ & $\begin{array}{c}\text { XS } \\
\text { granite }\end{array}$ & $\begin{array}{c}\text { XS } \\
\text { granite }\end{array}$ & $\begin{array}{c}\text { XS } \\
\text { granite }\end{array}$ & $\begin{array}{c}\text { XS } \\
\text { granite }\end{array}$ & $\begin{array}{c}\text { XS } \\
\text { granite }\end{array}$ & $\begin{array}{c}\mathrm{XS} \\
\text { granite }\end{array}$ & $\begin{array}{c}\text { XS } \\
\text { granite }\end{array}$ & $\begin{array}{c}\text { XS } \\
\text { granite }\end{array}$ & $\begin{array}{c}\text { XS } \\
\text { granite }\end{array}$ & $\begin{array}{c}\text { MA } \\
\text { tonalite }\end{array}$ & $\begin{array}{c}\text { MA } \\
\text { tonalite }\end{array}$ & $\begin{array}{c}\text { MA } \\
\text { tonalite }\end{array}$ \\
\hline Analysis & 1 & 2 & 3 & 4 & 5 & 6 & 7 & 8 & 9 & 10 & 11 & 1 & 2 & 3 \\
\hline $\mathrm{SiO}_{2}$ & 45.71 & 45.46 & 46.16 & 47.01 & 45.03 & 45.25 & 46.49 & 44.21 & 45.35 & 45.00 & 45.75 & 45.11 & 44.64 & 44.63 \\
\hline $\mathrm{Al}_{2} \mathrm{O}_{3}$ & 35.29 & 35.26 & 32.67 & 30.15 & 36.30 & 36.56 & 32.84 & 36.66 & 36.55 & 36.97 & 33.60 & 34.73 & 34.64 & 34.22 \\
\hline $\mathrm{FeO}$ & 1.13 & 1.17 & 1.64 & 1.74 & 0.94 & 1.08 & 1.39 & 0.98 & 0.96 & 0.87 & 1.47 & 1.40 & 1.45 & 1.94 \\
\hline $\mathrm{TiO}_{2}$ & 0.05 & 0.02 & 0.59 & 0.35 & 0.05 & 0.01 & 0.41 & 0.00 & 0.00 & 0.07 & 0.66 & 1.00 & 1.27 & 1.12 \\
\hline $\mathrm{MnO}$ & 0.00 & 0.00 & 0.00 & 0.02 & 0.05 & 0.00 & 0.00 & 0.00 & 0.00 & 0.00 & 0.00 & 0.00 & 0.02 & 0.03 \\
\hline $\mathrm{MgO}$ & 0.65 & 0.35 & 1.65 & 2.40 & 0.65 & 0.40 & 1.56 & 0.15 & 0.30 & 0.24 & 1.49 & 0.62 & 0.69 & 0.71 \\
\hline $\mathrm{CaO}$ & 0.02 & 0.01 & 0.00 & 0.00 & 0.00 & 0.00 & 0.00 & 0.00 & 0.04 & 0.00 & 0.02 & 0.00 & 0.01 & 0.00 \\
\hline $\mathrm{Na}_{2} \mathrm{O}$ & 0.85 & 0.96 & 0.36 & 0.31 & 0.92 & 0.99 & 0.53 & 1.00 & 0.96 & 1.05 & 0.68 & 0.47 & 0.46 & 0.53 \\
\hline $\mathrm{K}_{2} \mathrm{O}$ & 10.06 & 10.02 & 11.03 & 11.09 & 10.05 & 10.12 & 10.88 & 9.80 & 10.19 & 9.57 & 10.43 & 10.84 & 10.90 & 11.01 \\
\hline $\mathrm{BaO}$ & 0.00 & 0.00 & 0.18 & 0.11 & 0.02 & 0.00 & 0.22 & 0.08 & 0.05 & 0.12 & 0.15 & 0.13 & 0.12 & 0.10 \\
\hline $\mathrm{V}_{2} \mathrm{O}_{3}$ & 0.02 & 0.00 & 0.03 & 0.02 & 0.01 & 0.00 & 0.03 & 0.01 & 0.03 & 0.00 & 0.00 & 0.00 & 0.01 & 0.05 \\
\hline $\mathrm{Cl}$ & 0.02 & 0.00 & 0.02 & 0.03 & 0.01 & 0.01 & 0.00 & 0.06 & 0.02 & 0.03 & 0.04 & 0.01 & 0.00 & 0.00 \\
\hline $\mathrm{H}_{2} \mathrm{O}$ & 6.22 & 6.74 & 5.69 & 6.77 & 5.99 & 5.60 & 5.65 & 7.08 & 5.56 & 6.09 & 5.71 & 5.70 & 5.79 & 5.65 \\
\hline Total & 100.002 & 100.00 & 100.00 & 100.00 & 100.00 & 100.00 & 100.00 & 100.00 & 100.00 & 100.00 & 100.00 & 100.00 & 100.00 & 100.00 \\
\hline
\end{tabular}


Table 3.2: Muscovite composition (2/2).

\begin{tabular}{|c|c|c|c|c|c|c|c|c|c|c|c|c|c|c|}
\hline Sample & 1.1 & 1.1 & 1.1 & 1.1 & 1.1 & 1.1 & 1.1 & 1.1 & 1.1 & 1.1 & 1.1 & NI-V-99 & NI-V-99 & NI-V-99 \\
\hline Unit & $\begin{array}{c}\text { XS } \\
\text { granite }\end{array}$ & $\begin{array}{c}\text { XS } \\
\text { granite }\end{array}$ & $\begin{array}{c}\text { XS } \\
\text { granite }\end{array}$ & $\begin{array}{c}\text { XS } \\
\text { granite }\end{array}$ & $\begin{array}{c}\text { XS } \\
\text { granite }\end{array}$ & $\begin{array}{c}\text { XS } \\
\text { granite }\end{array}$ & $\begin{array}{c}\text { XS } \\
\text { granite }\end{array}$ & $\begin{array}{c}\text { XS } \\
\text { granite }\end{array}$ & $\begin{array}{c}\text { XS } \\
\text { granite }\end{array}$ & $\begin{array}{c}\text { XS } \\
\text { granite }\end{array}$ & $\begin{array}{c}\text { XS } \\
\text { granite }\end{array}$ & $\begin{array}{c}\text { MA } \\
\text { tonalite }\end{array}$ & $\begin{array}{c}\text { MA } \\
\text { tonalite }\end{array}$ & $\begin{array}{c}\text { MA } \\
\text { tonalite }\end{array}$ \\
\hline Analysis & 1 & 2 & 3 & 4 & 5 & 6 & 7 & 8 & 9 & 10 & 11 & 1 & 2 & 3 \\
\hline $\mathrm{SiO}_{2}$ & 45.71 & 45.46 & 46.16 & 47.01 & 45.03 & 45.25 & 46.49 & 44.21 & 45.35 & 45.00 & 45.75 & 45.11 & 44.64 & 44.63 \\
\hline $\mathrm{Al}_{2} \mathrm{O}_{3}$ & 35.29 & 35.26 & 32.67 & 30.15 & 36.30 & 36.56 & 32.84 & 36.66 & 36.55 & 36.97 & 33.60 & 34.73 & 34.64 & 34.22 \\
\hline $\mathrm{FeO}$ & 1.13 & 1.17 & 1.64 & 1.74 & 0.94 & 1.08 & 1.39 & 0.98 & 0.96 & 0.87 & 1.47 & 1.40 & 1.45 & 1.94 \\
\hline $\mathrm{TiO}_{2}$ & 0.05 & 0.02 & 0.59 & 0.35 & 0.05 & 0.01 & 0.41 & 0.00 & 0.00 & 0.07 & 0.66 & 1.00 & 1.27 & 1.12 \\
\hline $\mathrm{MnO}$ & 0.00 & 0.00 & 0.00 & 0.02 & 0.05 & 0.00 & 0.00 & 0.00 & 0.00 & 0.00 & 0.00 & 0.00 & 0.02 & 0.03 \\
\hline $\mathrm{MgO}$ & 0.65 & 0.35 & 1.65 & 2.40 & 0.65 & 0.40 & 1.56 & 0.15 & 0.30 & 0.24 & 1.49 & 0.62 & 0.69 & 0.71 \\
\hline $\mathrm{CaO}$ & 0.02 & 0.01 & 0.00 & 0.00 & 0.00 & 0.00 & 0.00 & 0.00 & 0.04 & 0.00 & 0.02 & 0.00 & 0.01 & 0.00 \\
\hline $\mathrm{Na}_{2} \mathrm{O}$ & 0.85 & 0.96 & 0.36 & 0.31 & 0.92 & 0.99 & 0.53 & 1.00 & 0.96 & 1.05 & 0.68 & 0.47 & 0.46 & 0.53 \\
\hline $\mathrm{K}_{2} \mathrm{O}$ & 10.06 & 10.02 & 11.03 & 11.09 & 10.05 & 10.12 & 10.88 & 9.80 & 10.19 & 9.57 & 10.43 & 10.84 & 10.90 & 11.01 \\
\hline $\mathrm{BaO}$ & 0.00 & 0.00 & 0.18 & 0.11 & 0.02 & 0.00 & 0.22 & 0.08 & 0.05 & 0.12 & 0.15 & 0.13 & 0.12 & 0.10 \\
\hline $\mathrm{V}_{2} \mathrm{O}_{3}$ & 0.02 & 0.00 & 0.03 & 0.02 & 0.01 & 0.00 & 0.03 & 0.01 & 0.03 & 0.00 & 0.00 & 0.00 & 0.01 & 0.05 \\
\hline $\mathrm{Cl}$ & 0.02 & 0.00 & 0.02 & 0.03 & 0.01 & 0.01 & 0.00 & 0.06 & 0.02 & 0.03 & 0.04 & 0.01 & 0.00 & 0.00 \\
\hline $\mathrm{H}_{2} \mathrm{O}$ & 6.22 & 6.74 & 5.69 & 6.77 & 5.99 & 5.60 & 5.65 & 7.08 & 5.56 & 6.09 & 5.71 & 5.70 & 5.79 & 5.65 \\
\hline Total & 100.002 & 100.00 & 100.00 & 100.00 & 100.00 & 100.00 & 100.00 & 100.00 & 100.00 & 100.00 & 100.00 & 100.00 & 100.00 & 100.00 \\
\hline
\end{tabular}


Table 3.3: Garnet compositon (1/4).

\begin{tabular}{|c|c|c|c|c|c|c|c|c|c|c|c|c|c|}
\hline Sample & NI-V-90 & NI-V-90 & NI-V-90 & NI-V-90 & NI-V-90 & NI-V-90 & NI-V-90 & NI-V-90 & NI-V-90 & NI-V-90 & NI-V-90 & NI-V-90 & NI-V-90 \\
\hline Analysis & 1 & 2 & 3 & 4 & 5 & 6 & 7 & 8 & 9 & 10 & 11 & 12 & 13 \\
\hline Unit & $\begin{array}{c}\text { MA } \\
\text { tonalite }\end{array}$ & $\begin{array}{c}\text { MA } \\
\text { tonalite }\end{array}$ & $\begin{array}{c}\text { MA } \\
\text { tonalite }\end{array}$ & $\begin{array}{c}\text { MA } \\
\text { tonalite }\end{array}$ & $\begin{array}{c}\text { MA } \\
\text { tonalite }\end{array}$ & $\begin{array}{c}\text { MA } \\
\text { tonalite }\end{array}$ & $\begin{array}{c}\text { MA } \\
\text { tonalite }\end{array}$ & $\begin{array}{c}\text { MA } \\
\text { tonalite }\end{array}$ & $\begin{array}{c}\text { MA } \\
\text { tonalite }\end{array}$ & $\begin{array}{c}\text { MA } \\
\text { tonalite }\end{array}$ & $\begin{array}{c}\text { MA } \\
\text { tonalite }\end{array}$ & $\begin{array}{c}\text { MA } \\
\text { tonalite }\end{array}$ & $\begin{array}{c}\text { MA } \\
\text { tonalite }\end{array}$ \\
\hline $\mathrm{SiO}_{2}$ & 37.45 & 37.32 & 37.10 & 37.39 & 37.02 & 37.22 & 37.02 & 37.22 & 36.87 & 36.28 & 37.21 & 36.99 & 37.10 \\
\hline $\mathrm{Al}_{2} \mathrm{O}_{3}$ & 22.18 & 21.70 & 21.70 & 21.96 & 21.43 & 21.48 & 21.88 & 21.48 & 21.77 & 21.47 & 21.85 & 21.72 & 21.65 \\
\hline $\mathrm{FeO}$ & 27.09 & 32.66 & 32.64 & 32.07 & 28.26 & 31.94 & 31.96 & 31.86 & 31.74 & 31.35 & 32.03 & 32.39 & 32.12 \\
\hline $\mathrm{TiO}_{2}$ & 0.00 & 0.02 & 0.16 & 0.07 & 0.09 & 0.00 & 0.09 & 0.14 & 0.00 & 0.00 & 0.09 & 0.00 & 0.00 \\
\hline $\mathrm{MnO}$ & 2.74 & 2.42 & 2.08 & 2.16 & 1.95 & 1.69 & 1.37 & 1.48 & 1.57 & 1.57 & 1.66 & 1.51 & 2.35 \\
\hline $\mathrm{MgO}$ & 0.54 & 0.84 & 0.77 & 0.83 & 0.57 & 0.87 & 0.86 & 0.83 & 0.94 & 0.87 & 0.77 & 0.94 & 0.67 \\
\hline $\mathrm{CaO}$ & 11.20 & 7.08 & 7.57 & 7.54 & 10.39 & 7.83 & 7.98 & 7.86 & 7.89 & 7.93 & 7.97 & 7.89 & 7.34 \\
\hline $\mathrm{Na}_{2} \mathrm{O}$ & 0.06 & 0.04 & 0.00 & 0.02 & 0.03 & 0.05 & 0.00 & 0.01 & 0.03 & 0.04 & 0.01 & 0.01 & 0.01 \\
\hline $\mathrm{K}_{2} \mathrm{O}$ & 0.00 & 0.00 & 0.01 & 0.01 & 0.00 & 0.04 & 0.02 & 0.00 & 0.00 & 0.01 & 0.00 & 0.01 & 0.00 \\
\hline $\mathrm{BaO}$ & 0.00 & 0.00 & 0.07 & 0.09 & 0.01 & 0.14 & 0.00 & 0.00 & 0.06 & 0.02 & 0.00 & 0.00 & 0.02 \\
\hline $\mathrm{V}_{2} \mathrm{O}_{3}$ & 0.01 & 0.02 & 0.01 & 0.00 & 0.00 & 0.10 & 0.00 & 0.01 & 0.00 & 0.02 & 0.05 & 0.04 & 0.03 \\
\hline $\mathrm{F}$ & 0.00 & 0.00 & 0.00 & 0.00 & 0.00 & 0.00 & 0.00 & 0.00 & 0.03 & 0.00 & 0.04 & 0.03 & 0.01 \\
\hline $\mathrm{Cl}$ & 0.01 & 0.00 & 0.01 & 0.00 & 0.00 & 0.02 & 0.01 & 0.00 & 0.01 & 0.00 & 0.00 & 0.00 & 0.01 \\
\hline $\mathrm{H}_{2} \mathrm{O}$ & 0.00 & 0.00 & 0.00 & 0.00 & 0.25 & 0.00 & 0.00 & 0.00 & 0.00 & 0.43 & 0.00 & 0.00 & 0.00 \\
\hline Total & 101.26 & 102.09 & 102.13 & 102.13 & 100.00 & 101.38 & 101.18 & 100.89 & 100.86 & 100.00 & 101.66 & 101.51 & 101.30 \\
\hline
\end{tabular}


Table 3.4: Garnet compositon (2/4).

\begin{tabular}{|c|c|c|c|c|c|c|c|c|c|c|c|c|c|}
\hline Sample & NI-V-90 & NI-V-90 & NI-V-90 & NI-V-90 & NI-V-90 & NI-V-90 & NI-V-90 & NI-V-90 & NI-V-90 & NI-V-90 & $\begin{array}{c}\text { NI-VII- } \\
38\end{array}$ & $\begin{array}{c}\text { NI-VII- } \\
38\end{array}$ & $\begin{array}{c}\text { NI-VII- } \\
38\end{array}$ \\
\hline Analysis & 14 & 15 & 16 & 17 & 18 & 19 & 20 & 21 & 22 & 23 & 1 & 2 & 3 \\
\hline Unit & $\begin{array}{c}\text { MA } \\
\text { tonalite }\end{array}$ & $\begin{array}{c}\text { MA } \\
\text { tonalite }\end{array}$ & $\begin{array}{c}\text { MA } \\
\text { tonalite }\end{array}$ & $\begin{array}{c}\text { MA } \\
\text { tonalite }\end{array}$ & $\begin{array}{c}\text { MA } \\
\text { tonalite }\end{array}$ & $\begin{array}{c}\text { MA } \\
\text { tonalite }\end{array}$ & $\begin{array}{c}\text { MA } \\
\text { tonalite }\end{array}$ & $\begin{array}{c}\text { MA } \\
\text { tonalite }\end{array}$ & $\begin{array}{c}\text { MA } \\
\text { tonalite }\end{array}$ & $\begin{array}{c}\text { MA } \\
\text { tonalite }\end{array}$ & $\begin{array}{c}\mathrm{CQ} \\
\text { tonalite }\end{array}$ & $\begin{array}{c}\mathrm{CQ} \\
\text { tonalite }\end{array}$ & $\begin{array}{c}\mathrm{CQ} \\
\text { tonalite }\end{array}$ \\
\hline $\mathrm{SiO}_{2}$ & 37.23 & 37.27 & 36.88 & 37.34 & 37.63 & 37.76 & 37.48 & 37.73 & 37.29 & 37.91 & 34.86 & 37.59 & 37.45 \\
\hline $\mathrm{Al}_{2} \mathrm{O}_{3}$ & 21.72 & 21.77 & 21.39 & 21.88 & 22.04 & 21.85 & 22.02 & 21.99 & 22.03 & 22.19 & 20.22 & 21.86 & 22.13 \\
\hline $\mathrm{FeO}$ & 32.62 & 28.01 & 32.57 & 32.36 & 31.71 & 31.69 & 31.68 & 31.46 & 31.94 & 32.69 & 19.65 & 20.39 & 21.74 \\
\hline $\mathrm{TiO}_{2}$ & 0.14 & 0.14 & 0.12 & 0.02 & 0.00 & 0.05 & 0.00 & 0.07 & 0.23 & 0.00 & 0.19 & 0.10 & 0.04 \\
\hline $\mathrm{MnO}$ & 2.93 & 2.34 & 3.14 & 2.58 & 0.85 & 1.02 & 0.91 & 0.85 & 0.99 & 1.03 & 9.81 & 10.93 & 5.32 \\
\hline $\mathrm{MgO}$ & 0.87 & 0.59 & 0.91 & 0.80 & 0.77 & 0.64 & 0.69 & 0.68 & 0.69 & 0.72 & 0.52 & 0.59 & 0.73 \\
\hline $\mathrm{CaO}$ & 6.39 & 11.08 & 6.33 & 7.00 & 8.65 & 8.66 & 8.80 & 8.64 & 9.28 & 7.93 & 9.99 & 10.30 & 13.53 \\
\hline $\mathrm{Na}_{2} \mathrm{O}$ & 0.01 & 0.00 & 0.04 & 0.01 & 0.01 & 0.04 & 0.02 & 0.01 & 0.02 & 0.00 & 0.00 & 0.00 & 0.01 \\
\hline $\mathrm{K}_{2} \mathrm{O}$ & 0.00 & 0.00 & 0.01 & 0.00 & 0.00 & 0.02 & 0.00 & 0.00 & 0.02 & 0.00 & 0.04 & 0.00 & 0.00 \\
\hline $\mathrm{BaO}$ & 0.00 & 0.00 & 0.00 & 0.00 & 0.02 & 0.01 & 0.01 & 0.07 & 0.00 & 0.00 & 0.00 & 0.00 & 0.06 \\
\hline $\mathrm{V}_{2} \mathrm{O}_{3}$ & 0.02 & 0.04 & 0.03 & 0.01 & 0.03 & 0.05 & 0.00 & 0.00 & 0.00 & 0.00 & 0.04 & 0.06 & 0.05 \\
\hline $\mathrm{F}$ & 0.00 & 0.02 & 0.00 & 0.00 & 0.01 & 0.00 & 0.00 & 0.03 & 0.00 & 0.00 & 0.00 & 0.00 & 0.00 \\
\hline $\mathrm{Cl}$ & 0.01 & 0.01 & 0.00 & 0.00 & 0.00 & 0.03 & 0.00 & 0.00 & 0.00 & 0.00 & 0.00 & 0.00 & 0.00 \\
\hline $\mathrm{H}_{2} \mathrm{O}$ & 0.00 & 0.00 & 0.00 & 0.00 & 0.00 & 0.00 & 0.00 & 0.00 & 0.00 & 0.00 & 4.70 & 0.00 & 0.00 \\
\hline Total & 101.93 & 101.25 & 101.41 & 101.99 & 101.72 & 101.79 & 101.60 & 101.53 & 102.50 & 102.47 & 100.00 & 101.81 & 101.07 \\
\hline
\end{tabular}


Table 3.5: Garnet compositon (3/4).

\begin{tabular}{|c|c|c|c|c|c|c|c|c|c|c|c|c|c|}
\hline Sample & $\begin{array}{c}\text { NI-VII- } \\
38\end{array}$ & $\begin{array}{c}\text { NI-VII- } \\
38\end{array}$ & $\begin{array}{c}\text { NI-VII- } \\
38\end{array}$ & $\begin{array}{c}\text { NI-VII- } \\
38\end{array}$ & $\begin{array}{c}\text { NI-VII- } \\
38\end{array}$ & $\begin{array}{c}\text { NI-VII- } \\
38\end{array}$ & $\begin{array}{c}\text { NI-VII- } \\
38\end{array}$ & PI35 & PI35 & PI35 & PI35 & PI35 & PI35 \\
\hline Analysis & 4 & 5 & 6 & 7 & 8 & 9 & 10 & 1 & 2 & 3 & 4 & 5 & 6 \\
\hline Unit & $\begin{array}{c}\mathrm{CQ} \\
\text { tonalite }\end{array}$ & $\begin{array}{c}\mathrm{CQ} \\
\text { tonalite }\end{array}$ & $\begin{array}{c}\mathrm{CQ} \\
\text { tonalite }\end{array}$ & $\begin{array}{c}\mathrm{CQ} \\
\text { tonalite }\end{array}$ & $\begin{array}{c}\mathrm{CQ} \\
\text { tonalite }\end{array}$ & $\begin{array}{c}\mathrm{CQ} \\
\text { tonalite }\end{array}$ & $\begin{array}{c}\mathrm{CQ} \\
\text { tonalite }\end{array}$ & $\begin{array}{c}\text { MA } \\
\text { tonalite }\end{array}$ & $\begin{array}{c}\text { MA } \\
\text { tonalite }\end{array}$ & $\begin{array}{c}\text { MA } \\
\text { tonalite }\end{array}$ & $\begin{array}{c}\text { MA } \\
\text { tonalite }\end{array}$ & $\begin{array}{c}\text { MA } \\
\text { tonalite }\end{array}$ & $\begin{array}{c}\text { MA } \\
\text { tonalite }\end{array}$ \\
\hline $\mathrm{SiO}_{2}$ & 37.60 & 38.04 & 38.13 & 37.67 & 49.14 & 37.80 & 37.50 & 36.59 & 36.58 & 37.42 & 37.12 & 37.32 & 37.39 \\
\hline $\mathrm{Al}_{2} \mathrm{O}_{3}$ & 21.99 & 22.41 & 22.88 & 21.88 & 18.26 & 21.85 & 21.91 & 21.87 & 21.85 & 22.17 & 22.19 & 22.11 & 22.05 \\
\hline $\mathrm{FeO}$ & 22.55 & 19.54 & 19.60 & 21.21 & 16.92 & 21.87 & 22.45 & 35.08 & 34.46 & 35.21 & 34.13 & 34.58 & 34.59 \\
\hline $\mathrm{TiO}_{2}$ & 0.07 & 0.00 & 0.00 & 0.00 & 0.05 & 0.07 & 0.00 & 0.07 & 0.16 & 0.07 & 0.00 & 0.02 & 0.07 \\
\hline $\mathrm{MnO}$ & 6.98 & 7.01 & 8.25 & 8.11 & 7.18 & 7.11 & 5.82 & 4.17 & 3.78 & 3.29 & 3.38 & 3.40 & 3.47 \\
\hline $\mathrm{MgO}$ & 0.75 & 0.62 & 0.56 & 0.68 & 0.56 & 0.75 & 0.70 & 2.04 & 2.21 & 2.65 & 2.84 & 2.74 & 2.78 \\
\hline $\mathrm{CaO}$ & 11.60 & 13.81 & 12.34 & 11.18 & 10.57 & 11.50 & 12.28 & 1.38 & 1.39 & 1.47 & 1.41 & 1.30 & 1.38 \\
\hline $\mathrm{Na}_{2} \mathrm{O}$ & 0.00 & 0.00 & 0.04 & 0.03 & 0.00 & 0.00 & 0.01 & 0.02 & 0.00 & 0.00 & 0.02 & 0.00 & 0.04 \\
\hline $\mathrm{K}_{2} \mathrm{O}$ & 0.04 & 0.00 & 0.02 & 0.02 & 0.00 & 0.00 & 0.02 & 0.01 & 0.00 & 0.01 & 0.01 & 0.02 & 0.01 \\
\hline $\mathrm{BaO}$ & 0.05 & 0.00 & 0.00 & 0.00 & 0.13 & 0.06 & 0.16 & 0.06 & 0.00 & 0.00 & 0.10 & 0.01 & 0.01 \\
\hline $\mathrm{V}_{2} \mathrm{O}_{3}$ & 0.00 & 0.08 & 0.07 & 0.00 & 0.01 & 0.06 & 0.00 & 0.08 & 0.06 & 0.00 & 0.03 & 0.00 & 0.07 \\
\hline $\mathrm{F}$ & 0.00 & 0.00 & 0.00 & 0.00 & 0.00 & 0.00 & 0.00 & 0.00 & 0.00 & 0.00 & 0.00 & 0.00 & 0.00 \\
\hline $\mathrm{Cl}$ & 0.01 & 0.01 & 0.02 & 0.00 & 0.01 & 0.01 & 0.00 & 0.00 & 0.02 & 0.01 & 0.00 & 0.00 & 0.01 \\
\hline $\mathrm{H}_{2} \mathrm{O}^{*}$ & 0.00 & 0.00 & 0.00 & 0.00 & 0.00 & 0.00 & 0.00 & 0.00 & 0.00 & 0.00 & 0.00 & 0.00 & 0.00 \\
\hline Total & 101.63 & 101.52 & 101.90 & 100.77 & 102.82 & 101.08 & 100.85 & 101.35 & 100.50 & 102.28 & 101.22 & 101.50 & 101.86 \\
\hline
\end{tabular}


Table 3.6: Garnet compositon (4/4).

\begin{tabular}{|c|c|c|c|c|c|c|c|c|c|c|c|c|c|c|}
\hline Sample & PI35 & PI35 & PI35 & PI35 & PI35 & PI35 & PI35 & PI35 & PI35 & PI35 & PI35 & PI35 & PI35 & PI35 \\
\hline Analysis & 7 & 8 & 9 & 10 & 11 & 12 & 13 & 14 & 15 & 16 & 17 & 18 & 19 & 20 \\
\hline Unit & $\begin{array}{c}\text { MA } \\
\text { tonalite }\end{array}$ & $\begin{array}{c}\text { MA } \\
\text { tonalite }\end{array}$ & $\begin{array}{c}\text { MA } \\
\text { tonalite }\end{array}$ & $\begin{array}{c}\text { MA } \\
\text { tonalite }\end{array}$ & $\begin{array}{c}\text { MA } \\
\text { tonalite }\end{array}$ & $\begin{array}{c}\text { MA } \\
\text { tonalite }\end{array}$ & $\begin{array}{c}\text { MA } \\
\text { tonalite }\end{array}$ & $\begin{array}{c}\text { MA } \\
\text { tonalite }\end{array}$ & $\begin{array}{c}\text { MA } \\
\text { tonalite }\end{array}$ & $\begin{array}{c}\text { MA } \\
\text { tonalite }\end{array}$ & $\begin{array}{c}\text { MA } \\
\text { tonalite }\end{array}$ & $\begin{array}{c}\text { MA } \\
\text { tonalite }\end{array}$ & $\begin{array}{c}\text { MA } \\
\text { tonalite }\end{array}$ & $\begin{array}{c}\text { MA } \\
\text { tonalite }\end{array}$ \\
\hline $\mathrm{SiO}_{2}$ & 37.19 & 37.24 & 36.95 & 36.96 & 37.00 & 36.95 & 37.06 & 36.88 & 37.24 & 37.45 & 37.57 & 37.39 & 37.19 & 36.98 \\
\hline $\mathrm{Al}_{2} \mathrm{O}_{3}$ & 22.15 & 21.94 & 22.26 & 21.93 & 21.81 & 22.27 & 22.05 & 21.99 & 22.21 & 22.07 & 21.88 & 22.00 & 21.75 & 22.06 \\
\hline $\mathrm{FeO}$ & 34.72 & 34.88 & 34.44 & 34.43 & 34.23 & 35.06 & 33.73 & 34.63 & 35.29 & 33.90 & 34.59 & 35.05 & 34.58 & 34.74 \\
\hline $\mathrm{TiO}_{2}$ & 0.00 & 0.00 & 0.09 & 0.00 & 0.00 & 0.00 & 0.03 & 0.00 & 0.20 & 0.00 & 0.00 & 0.09 & 0.14 & 0.00 \\
\hline $\mathrm{MnO}$ & 3.51 & 3.50 & 3.70 & 4.39 & 3.96 & 3.99 & 5.58 & 4.21 & 3.75 & 3.52 & 3.68 & 4.36 & 4.54 & 4.82 \\
\hline $\mathrm{MgO}$ & 2.80 & 2.24 & 2.34 & 2.18 & 2.29 & 2.17 & 1.47 & 2.04 & 2.30 & 2.31 & 2.29 & 2.04 & 1.92 & 1.67 \\
\hline $\mathrm{CaO}$ & 1.34 & 1.43 & 1.36 & 1.37 & 1.34 & 1.32 & 1.30 & 1.34 & 1.35 & 1.42 & 1.42 & 1.37 & 1.18 & 1.34 \\
\hline $\mathrm{Na}_{2} \mathrm{O}$ & 0.06 & 0.00 & 0.00 & 0.03 & 0.01 & 0.01 & 0.04 & 0.00 & 0.02 & 0.03 & 0.00 & 0.00 & 0.02 & 0.00 \\
\hline $\mathrm{K}_{2} \mathrm{O}$ & 0.03 & 0.04 & 0.00 & 0.00 & 0.00 & 0.02 & 0.00 & 0.01 & 0.00 & 0.00 & 0.03 & 0.00 & 0.00 & 0.02 \\
\hline $\mathrm{BaO}$ & 0.00 & 0.00 & 0.09 & 0.07 & 0.00 & 0.00 & 0.00 & 0.00 & 0.00 & 0.00 & 0.07 & 0.01 & 0.00 & 0.02 \\
\hline $\mathrm{V}_{2} \mathrm{O}_{3}$ & 0.01 & 0.00 & 0.00 & 0.00 & 0.00 & 0.02 & 0.01 & 0.06 & 0.00 & 0.00 & 0.02 & 0.00 & 0.09 & 0.01 \\
\hline $\mathrm{F}$ & 0.00 & 0.00 & 0.00 & 0.00 & 0.00 & 0.00 & 0.00 & 0.00 & 0.02 & 0.00 & 0.00 & 0.00 & 0.00 & 0.00 \\
\hline $\mathrm{Cl}$ & 0.00 & 0.01 & 0.01 & 0.00 & 0.00 & 0.00 & 0.00 & 0.00 & 0.02 & 0.00 & 0.00 & 0.00 & 0.00 & 0.00 \\
\hline $\mathrm{H}_{2} \mathrm{O} *$ & 0.00 & 0.00 & 0.00 & 0.00 & 0.00 & 0.00 & 0.00 & 0.00 & 0.00 & 0.00 & 0.00 & 0.00 & 0.00 & 0.00 \\
\hline Total & 101.80 & 101.27 & 101.23 & 101.37 & 100.63 & 101.81 & 101.27 & 101.16 & 102.38 & 100.69 & 101.55 & 102.31 & 101.40 & 101.66 \\
\hline
\end{tabular}

Table 3.7: Garnet end-member based on 12 oxygens. $\mathrm{Fe}^{2+} / \mathrm{Fe}^{3+}$ calculated assuming full site occupancy.

\begin{tabular}{lccccccrrr} 
Sample & Analysis & Unit & Almandine $(\%)$ & Andradite $(\%)$ & Grossular $(\%)$ & Pyrope $(\%)$ & Spessartine $(\%)$ & Uvarovite $(\%)$ & Total \\
\hline NI-V-90 & 1 & MA & 59.65 & 0.00 & 32.03 & 2.13 & 6.19 & 0.00 & 100.00 \\
NI-V-90 & 2 & MA & 70.84 & 0.42 & 19.91 & 3.34 & 5.49 & 0.00 & 100.00 \\
NI-V-90 & 3 & MA & 70.27 & 0.70 & 21.17 & 3.11 & 4.76 & 0.00 & 100.00 \\
NI-V-90 & 4 & MA & 70.22 & 0.00 & 21.60 & 3.29 & 4.90 & 0.00 & 100.00 \\
NI-V-90 & 5 & MA & 63.16 & 0.00 & 30.09 & 2.30 & 4.46
\end{tabular}




\begin{tabular}{|c|c|c|c|c|c|c|c|c|c|}
\hline NI-V-90 & 6 & MA & 70.12 & 0.27 & 22.28 & 3.48 & 3.85 & 0.00 & 100.00 \\
\hline NI-V-90 & 7 & MA & 70.32 & 0.00 & 23.09 & 3.44 & 3.14 & 0.00 & 100.00 \\
\hline NI-V-90 & 8 & MA & 70.69 & 0.00 & 22.61 & 3.32 & 3.37 & 0.00 & 100.00 \\
\hline NI-V-90 & 9 & MA & 69.69 & 0.00 & 22.92 & 3.78 & 3.60 & 0.00 & 100.00 \\
\hline NI-V-90 & 10 & MA & 69.33 & 0.12 & 23.31 & 3.59 & 3.66 & 0.00 & 100.00 \\
\hline NI-V-90 & 11 & MA & 70.18 & 0.00 & 22.96 & 3.09 & 3.77 & 0.00 & 100.00 \\
\hline NI-V-90 & 12 & MA & 69.93 & 0.63 & 22.23 & 3.77 & 3.45 & 0.00 & 100.00 \\
\hline NI-V-90 & 13 & MA & 70.75 & 0.00 & 21.19 & 2.68 & 5.38 & 0.00 & 100.00 \\
\hline NI-V-90 & 14 & MA & 71.47 & 0.00 & 18.40 & 3.48 & 6.65 & 0.00 & 100.00 \\
\hline NI-V-90 & 15 & MA & 60.47 & 0.19 & 31.67 & 2.35 & 5.33 & 0.00 & 100.00 \\
\hline NI-V-90 & 16 & MA & 70.74 & 0.94 & 17.43 & 3.67 & 7.21 & 0.00 & 100.00 \\
\hline NI-V-90 & 17 & MA & 70.89 & 0.00 & 20.08 & 3.19 & 5.84 & 0.00 & 100.00 \\
\hline NI-V-90 & 18 & MA & 70.43 & 0.00 & 24.62 & 3.05 & 1.90 & 0.00 & 100.00 \\
\hline NI-V-90 & 19 & MA & 70.63 & 0.00 & 24.57 & 2.52 & 2.28 & 0.00 & 100.00 \\
\hline NI-V-90 & 20 & MA & 70.05 & 0.00 & 25.15 & 2.75 & 2.05 & 0.00 & 100.00 \\
\hline NI-V-90 & 21 & MA & 70.84 & 0.00 & 24.54 & 2.70 & 1.92 & 0.00 & 100.00 \\
\hline NI-V-90 & 22 & MA & 68.31 & 0.28 & 26.38 & 2.77 & 2.25 & 0.00 & 100.00 \\
\hline NI-V-90 & 23 & MA & 72.44 & 0.00 & 22.42 & 2.84 & 2.29 & 0.00 & 100.00 \\
\hline NI-VII-38 & 1 & CQ & 43.26 & 1.36 & 29.34 & 2.22 & 23.82 & 0.00 & 100.00 \\
\hline NI-VII-38 & 2 & CQ & 43.66 & 0.00 & 29.37 & 2.35 & 24.62 & 0.00 & 100.00 \\
\hline NI-VII-38 & 3 & CQ & 46.37 & 0.00 & 38.69 & 2.90 & 12.04 & 0.00 & 100.00 \\
\hline NI-VII-38 & 4 & CQ & 48.26 & 0.00 & 33.06 & 2.95 & 15.73 & 0.00 & 100.00 \\
\hline NI-VII-38 & 5 & CQ & 43.06 & 0.00 & 38.89 & 2.45 & 15.60 & 0.00 & 100.00 \\
\hline NI-VII-38 & 6 & CQ & 44.82 & 0.00 & 34.67 & 2.19 & 18.32 & 0.00 & 100.00 \\
\hline NI-VII-38 & 7 & CQ & 47.28 & 0.00 & 31.80 & 2.68 & 18.24 & 0.00 & 100.00 \\
\hline NI-VII-38 & 8 & CQ & 43.50 & 0.00 & 35.07 & 2.60 & 18.83 & 0.00 & 100.00 \\
\hline NI-VII-38 & 9 & CQ & 48.50 & 0.00 & 32.60 & 2.97 & 15.94 & 0.00 & 100.00 \\
\hline NI-VII-38 & 10 & CQ & 48.97 & 0.00 & 35.10 & 2.79 & 13.14 & 0.00 & 100.00 \\
\hline PI35 & 1 & MA & 78.02 & 0.00 & 4.04 & 8.30 & 9.64 & 0.00 & 100.00 \\
\hline
\end{tabular}




\begin{tabular}{|c|c|c|c|c|c|c|c|c|c|}
\hline PI35 & 2 & MA & 78.17 & 0.00 & 4.07 & 9.00 & 8.75 & 0.00 & 100.00 \\
\hline PI35 & 3 & MA & 77.80 & 0.00 & 4.20 & 10.55 & 7.44 & 0.00 & 100.00 \\
\hline PI35 & 4 & MA & 76.81 & 0.00 & 4.06 & 11.41 & 7.72 & 0.00 & 100.00 \\
\hline PI35 & 5 & MA & 77.60 & 0.00 & 3.74 & 10.95 & 7.71 & 0.00 & 100.00 \\
\hline PI35 & 6 & MA & 77.10 & 0.00 & 3.96 & 11.07 & 7.87 & 0.00 & 100.00 \\
\hline PI35 & 7 & MA & 76.94 & 0.00 & 3.85 & 11.22 & 7.99 & 0.00 & 100.00 \\
\hline PI35 & 8 & MA & 78.96 & 0.00 & 4.10 & 8.98 & 7.96 & 0.00 & 100.00 \\
\hline PI35 & 9 & MA & 78.13 & 0.00 & 3.96 & 9.43 & 8.48 & 0.00 & 100.00 \\
\hline PI35 & 10 & MA & 77.16 & 0.00 & 3.97 & 8.80 & 10.06 & 0.00 & 100.00 \\
\hline PI35 & 11 & MA & 77.87 & 0.00 & 3.87 & 9.21 & 9.05 & 0.00 & 100.00 \\
\hline PI35 & 12 & MA & 78.28 & 0.00 & 3.83 & 8.74 & 9.15 & 0.00 & 100.00 \\
\hline PI35 & 13 & MA & 77.59 & 0.00 & 3.76 & 5.89 & 12.75 & 0.00 & 100.00 \\
\hline PI35 & 14 & MA & 78.20 & 0.00 & 3.90 & 8.24 & 9.66 & 0.00 & 100.00 \\
\hline PI35 & 15 & MA & 78.39 & 0.00 & 3.88 & 9.21 & 8.52 & 0.00 & 100.00 \\
\hline PI35 & 16 & MA & 78.65 & 0.00 & 4.09 & 9.25 & 8.02 & 0.00 & 100.00 \\
\hline PI35 & 17 & MA & 78.52 & 0.00 & 4.07 & 9.10 & 8.31 & 0.00 & 100.00 \\
\hline PI35 & 18 & MA & 78.09 & 0.00 & 3.91 & 8.13 & 9.87 & 0.00 & 100.00 \\
\hline PI35 & 19 & MA & 78.58 & 0.00 & 3.39 & 7.70 & 10.34 & 0.00 & 100.00 \\
\hline PI35 & 20 & MA & 78.34 & 0.00 & 3.89 & 6.74 & 11.03 & 0.00 & 100.00 \\
\hline
\end{tabular}


Table 3.8: Biotite composition (1/9).

\begin{tabular}{|c|c|c|c|c|c|c|c|c|c|c|c|c|c|}
\hline Sample & 1.1 & 1.1 & 1.1 & 1.1 & 1.1 & PI-15 & PI-15 & PI-15 & PI-15 & PI-15 & PI-15 & PI-15 & PI-15 \\
\hline Analysis & 1 & 2 & 3 & 4 & 5 & 1 & 2 & 3 & 4 & 5 & 6 & 7 & 8 \\
\hline Unit & $\begin{array}{c}\text { XS } \\
\text { granite }\end{array}$ & $\begin{array}{c}\text { XS } \\
\text { granite }\end{array}$ & $\begin{array}{c}\text { XS } \\
\text { granite }\end{array}$ & $\begin{array}{c}\text { XS } \\
\text { granite }\end{array}$ & $\begin{array}{c}\text { XS } \\
\text { granite }\end{array}$ & $\begin{array}{c}\mathrm{CQ} \\
\text { tonalite }\end{array}$ & $\begin{array}{c}\mathrm{CQ} \\
\text { tonalite }\end{array}$ & $\begin{array}{c}\mathrm{CQ} \\
\text { tonalite }\end{array}$ & $\begin{array}{c}\mathrm{CQ} \\
\text { tonalite }\end{array}$ & $\begin{array}{c}\mathrm{CQ} \\
\text { tonalite }\end{array}$ & $\begin{array}{c}\mathrm{CQ} \\
\text { tonalite }\end{array}$ & $\begin{array}{c}\mathrm{CQ} \\
\text { tonalite }\end{array}$ & $\begin{array}{c}\mathrm{CQ} \\
\text { tonalite }\end{array}$ \\
\hline $\mathrm{SiO}_{2}$ & 36.72 & 36.41 & 36.29 & 36.54 & 36.24 & 35.31 & 35.45 & 35.40 & 34.05 & 35.15 & 35.17 & 35.75 & 35.49 \\
\hline $\mathrm{Al}_{2} \mathrm{O}_{3}$ & 17.66 & 17.61 & 17.93 & 17.87 & 17.91 & 17.93 & 17.90 & 18.10 & 17.03 & 17.90 & 18.35 & 17.89 & 17.90 \\
\hline $\mathrm{FeO}$ & 17.16 & 17.01 & 17.52 & 16.93 & 17.22 & 20.85 & 20.80 & 20.13 & 21.06 & 20.28 & 20.48 & 20.55 & 20.79 \\
\hline $\mathrm{TiO}_{2}$ & 2.10 & 1.80 & 1.94 & 1.61 & 1.40 & 2.03 & 1.74 & 2.01 & 1.83 & 1.59 & 2.17 & 2.33 & 1.91 \\
\hline $\mathrm{MnO}$ & 0.26 & 0.08 & 0.15 & 0.23 & 0.15 & 0.40 & 0.44 & 0.55 & 0.27 & 0.42 & 0.41 & 0.40 & 0.45 \\
\hline $\mathrm{MgO}$ & 12.53 & 12.38 & 12.27 & 12.40 & 12.41 & 8.29 & 8.65 & 8.55 & 7.96 & 9.27 & 8.73 & 8.27 & 8.68 \\
\hline $\mathrm{CaO}$ & 0.04 & 0.00 & 0.04 & 0.01 & 0.03 & 0.02 & 0.05 & 0.03 & 0.14 & 0.02 & 0.01 & 0.02 & 0.02 \\
\hline $\mathrm{Na}_{2} \mathrm{O}$ & 0.06 & 0.11 & 0.10 & 0.13 & 0.15 & 0.32 & 0.09 & 0.06 & 0.14 & 0.06 & 0.06 & 0.09 & 0.09 \\
\hline $\mathrm{K}_{2} \mathrm{O}$ & 9.87 & 9.59 & 9.55 & 9.65 & 9.55 & 9.35 & 9.44 & 9.68 & 9.27 & 8.96 & 9.43 & 9.77 & 9.57 \\
\hline $\mathrm{BaO}$ & 0.00 & 0.00 & 0.12 & 0.05 & 0.05 & 0.00 & 0.09 & 0.10 & 0.05 & 0.02 & 0.17 & 0.09 & 0.04 \\
\hline $\mathrm{V}_{2} \mathrm{O}_{3}$ & 0.04 & 0.07 & 0.02 & 0.02 & 0.00 & 0.07 & 0.05 & 0.06 & 0.05 & 0.03 & 0.06 & 0.05 & 0.08 \\
\hline $\mathrm{F}$ & 0.64 & 0.59 & 0.55 & 0.46 & 0.61 & 0.56 & 0.45 & 0.51 & 0.44 & 0.51 & 0.43 & 0.40 & 0.32 \\
\hline $\mathrm{Cl}$ & 0.01 & 0.00 & 0.01 & 0.03 & 0.01 & 0.08 & 0.02 & 0.03 & 0.02 & 0.04 & 0.03 & 0.02 & 0.03 \\
\hline $\mathrm{H}_{2} \mathrm{O}$ & 3.20 & 4.62 & 3.76 & 4.30 & 4.53 & 5.04 & 5.01 & 5.02 & 7.88 & 6.00 & 4.69 & 4.56 & 4.79 \\
\hline Total & 100.00 & 100.00 & 100.00 & 100.00 & 100.00 & 100.00 & 100.00 & 100.00 & 100.00 & 100.00 & 100.00 & 100.00 & 100.00 \\
\hline
\end{tabular}


Table 3.9: Biotite composition (2/9).

\begin{tabular}{|c|c|c|c|c|c|c|c|c|c|c|c|c|c|}
\hline Sample & PI-15 & $\begin{array}{c}\text { NI-V- } \\
90 \mathrm{~A}\end{array}$ & $\begin{array}{c}\text { NI-V- } \\
90 \mathrm{~A}\end{array}$ & $\begin{array}{l}\text { NI-V- } \\
90 \mathrm{~A}\end{array}$ & $\begin{array}{c}\text { NI-V- } \\
90 \mathrm{~A}\end{array}$ & $\begin{array}{c}\text { NI-V- } \\
90 \mathrm{~A}\end{array}$ & $\begin{array}{c}\text { NI-V- } \\
90 \mathrm{~A}\end{array}$ & $\begin{array}{c}\text { NI-V- } \\
90 \mathrm{~A}\end{array}$ & $\begin{array}{c}\text { NI-V- } \\
90 \mathrm{~A}\end{array}$ & $\begin{array}{c}\text { NI-VIII- } \\
122\end{array}$ & $\begin{array}{c}\text { NI-VIII- } \\
122\end{array}$ & $\begin{array}{c}\text { NI-VIII- } \\
122\end{array}$ & $\begin{array}{c}\text { NI-VIII- } \\
122\end{array}$ \\
\hline Analysis & 9 & 1 & 2 & 3 & 4 & 5 & 6 & 7 & 8 & 1 & 2 & 3 & 4 \\
\hline Unit & $\begin{array}{c}\mathrm{CQ} \\
\text { tonalite }\end{array}$ & $\begin{array}{c}\text { MA } \\
\text { tonalite }\end{array}$ & $\begin{array}{c}\text { MA } \\
\text { tonalite }\end{array}$ & $\begin{array}{c}\text { MA } \\
\text { tonalite }\end{array}$ & $\begin{array}{c}\text { MA } \\
\text { tonalite }\end{array}$ & $\begin{array}{c}\text { MA } \\
\text { tonalite }\end{array}$ & $\begin{array}{c}\text { MA } \\
\text { tonalite }\end{array}$ & $\begin{array}{c}\text { MA } \\
\text { tonalite }\end{array}$ & $\begin{array}{c}\text { MA } \\
\text { tonalite }\end{array}$ & $\begin{array}{c}\mathrm{RM} \\
\text { tonalite }\end{array}$ & $\begin{array}{c}\mathrm{RM} \\
\text { tonalite }\end{array}$ & $\begin{array}{c}\mathrm{RM} \\
\text { tonalite }\end{array}$ & $\begin{array}{c}\mathrm{RM} \\
\text { tonalite }\end{array}$ \\
\hline $\mathrm{SiO}_{2}$ & 35.61 & 34.62 & 34.17 & 34.05 & 33.65 & 34.23 & 34.01 & 33.94 & 33.71 & 35.49 & 36.02 & 36.02 & 35.72 \\
\hline $\mathrm{Al}_{2} \mathrm{O}_{3}$ & 18.28 & 18.32 & 18.73 & 18.22 & 18.41 & 18.40 & 18.33 & 18.17 & 18.28 & 16.35 & 16.12 & 15.97 & 16.24 \\
\hline $\mathrm{FeO}$ & 20.45 & 26.11 & 26.32 & 25.39 & 26.59 & 26.90 & 26.52 & 27.31 & 26.64 & 20.88 & 20.80 & 20.27 & 20.73 \\
\hline $\mathrm{TiO}_{2}$ & 2.07 & 2.10 & 1.87 & 2.06 & 2.73 & 2.05 & 2.33 & 2.36 & 2.70 & 1.51 & 1.20 & 1.58 & 1.42 \\
\hline $\mathrm{MnO}$ & 0.35 & 0.00 & 0.09 & 0.13 & 0.00 & 0.17 & 0.06 & 0.12 & 0.08 & 0.13 & 0.18 & 0.06 & 0.20 \\
\hline $\mathrm{MgO}$ & 8.78 & 5.04 & 5.15 & 5.14 & 4.97 & 4.70 & 5.08 & 4.74 & 5.13 & 10.78 & 10.95 & 10.96 & 10.61 \\
\hline $\mathrm{CaO}$ & 0.02 & 0.02 & 0.02 & 0.08 & 0.06 & 0.01 & 0.08 & 0.03 & 0.03 & 0.12 & 0.07 & 0.09 & 0.10 \\
\hline $\mathrm{Na}_{2} \mathrm{O}$ & 0.07 & 0.05 & 0.15 & 0.09 & 0.04 & 0.10 & 0.09 & 0.09 & 0.06 & 0.10 & 0.06 & 0.11 & 0.07 \\
\hline $\mathrm{K}_{2} \mathrm{O}$ & 9.67 & 9.53 & 9.09 & 9.03 & 9.15 & 9.48 & 8.94 & 9.51 & 8.95 & 8.99 & 9.56 & 9.17 & 9.36 \\
\hline $\mathrm{BaO}$ & 0.16 & 0.19 & 0.11 & 0.35 & 0.20 & 0.12 & 0.14 & 0.14 & 0.10 & 0.15 & 0.19 & 0.20 & 0.08 \\
\hline $\mathrm{V}_{2} \mathrm{O}_{3}$ & 0.07 & 0.05 & 0.03 & 0.05 & 0.05 & 0.02 & 0.08 & 0.02 & 0.07 & 0.05 & 0.04 & 0.05 & 0.00 \\
\hline $\mathrm{F}$ & 0.33 & 0.22 & 0.17 & 0.10 & 0.23 & 0.19 & 0.09 & 0.09 & 0.10 & 0.37 & 0.47 & 0.43 & 0.54 \\
\hline $\mathrm{Cl}$ & 0.02 & 0.00 & 0.00 & 0.02 & 0.00 & 0.01 & 0.02 & 0.00 & 0.01 & 0.07 & 0.11 & 0.08 & 0.09 \\
\hline $\mathrm{H}_{2} \mathrm{O}$ & 4.28 & 3.85 & 4.17 & 5.35 & 4.03 & 3.70 & 4.28 & 3.53 & 4.18 & 5.18 & 4.46 & 5.23 & 5.10 \\
\hline Total & 100.00 & 100.00 & 100.00 & 100.00 & 100.00 & 100.00 & 100.00 & 100.00 & 100.00 & 100.00 & 100.00 & 100.00 & 100.00 \\
\hline
\end{tabular}


Table 3.10: Biotite composition (3/9).

\begin{tabular}{|c|c|c|c|c|c|c|c|c|c|c|c|c|c|}
\hline Sample & $\begin{array}{c}\text { NI-VIII- } \\
122\end{array}$ & $\begin{array}{c}\text { NI-VIII- } \\
122\end{array}$ & PI-41 & PI-41 & PI-41 & PI-41 & PI-41 & PI-41 & PI-41 & PI-41 & PI-41 & PI-41 & PI-41 \\
\hline Analysis & 5 & 6 & 1 & 2 & 3 & 4 & 5 & 6 & 7 & 8 & 9 & 10 & 11 \\
\hline Unit & $\begin{array}{c}\mathrm{RM} \\
\text { tonalite }\end{array}$ & $\begin{array}{c}\mathrm{RM} \\
\text { tonalite }\end{array}$ & $\begin{array}{c}\mathrm{RM} \\
\text { tonalite }\end{array}$ & $\begin{array}{c}\mathrm{RM} \\
\text { tonalite }\end{array}$ & $\begin{array}{c}\text { RM } \\
\text { tonalite }\end{array}$ & $\begin{array}{c}\mathrm{RM} \\
\text { tonalite }\end{array}$ & $\begin{array}{c}\mathrm{RM} \\
\text { tonalite }\end{array}$ & $\begin{array}{c}\mathrm{RM} \\
\text { tonalite }\end{array}$ & $\begin{array}{c}\mathrm{RM} \\
\text { tonalite }\end{array}$ & $\begin{array}{c}\mathrm{RM} \\
\text { tonalite }\end{array}$ & $\begin{array}{c}\mathrm{RM} \\
\text { tonalite }\end{array}$ & $\begin{array}{c}\mathrm{RM} \\
\text { tonalite }\end{array}$ & $\begin{array}{c}\mathrm{RM} \\
\text { tonalite }\end{array}$ \\
\hline $\mathrm{SiO}_{2}$ & 35.37 & 36.18 & 35.00 & 35.45 & 35.48 & 35.36 & 35.37 & 35.48 & 36.24 & 35.69 & 35.75 & 35.36 & 35.78 \\
\hline $\mathrm{Al}_{2} \mathrm{O}_{3}$ & 16.21 & 16.11 & 16.25 & 15.85 & 15.90 & 16.40 & 16.20 & 16.13 & 16.25 & 16.12 & 16.60 & 15.87 & 16.25 \\
\hline $\mathrm{FeO}$ & 21.37 & 20.50 & 23.15 & 24.00 & 24.27 & 23.75 & 24.05 & 24.30 & 21.06 & 21.22 & 23.68 & 23.50 & 23.63 \\
\hline $\mathrm{TiO}_{2}$ & 1.71 & 1.55 & 2.27 & 2.40 & 2.07 & 2.20 & 1.87 & 2.06 & 1.77 & 2.17 & 1.98 & 1.77 & 1.57 \\
\hline $\mathrm{MnO}$ & 0.18 & 0.22 & 0.44 & 0.31 & 0.38 & 0.44 & 0.27 & 0.36 & 0.47 & 0.33 & 0.47 & 0.37 & 0.19 \\
\hline $\mathrm{MgO}$ & 10.69 & 10.97 & 8.40 & 8.40 & 8.13 & 8.25 & 8.40 & 7.81 & 9.92 & 10.06 & 8.28 & 7.94 & 8.73 \\
\hline $\mathrm{CaO}$ & 0.06 & 0.06 & 0.00 & 0.06 & 0.02 & 0.07 & 0.02 & 0.08 & 0.05 & 0.02 & 0.00 & 0.03 & 0.00 \\
\hline $\mathrm{Na}_{2} \mathrm{O}$ & 0.13 & 0.05 & 0.02 & 0.09 & 0.05 & 0.03 & 0.00 & 0.05 & 0.00 & 0.00 & 0.01 & 0.04 & 0.00 \\
\hline $\mathrm{K}_{2} \mathrm{O}$ & 9.48 & 9.46 & 9.84 & 9.62 & 9.77 & 9.67 & 9.65 & 9.27 & 9.61 & 9.83 & 9.76 & 9.58 & 9.82 \\
\hline $\mathrm{BaO}$ & 0.17 & 0.19 & 0.14 & 0.12 & 0.10 & 0.03 & 0.13 & 0.02 & 0.12 & 0.20 & 0.05 & 0.07 & 0.14 \\
\hline $\mathrm{V}_{2} \mathrm{O}_{3}$ & 0.02 & 0.09 & 0.04 & 0.07 & 0.04 & 0.08 & 0.02 & 0.06 & 0.00 & 0.07 & 0.04 & 0.03 & 0.05 \\
\hline $\mathrm{F}$ & 0.43 & 0.50 & 0.64 & 0.61 & 0.53 & 0.62 & 0.62 & 0.53 & 0.78 & 0.71 & 0.66 & 0.63 & 0.63 \\
\hline $\mathrm{Cl}$ & 0.08 & 0.09 & 0.00 & 0.04 & 0.02 & 0.02 & 0.05 & 0.01 & 0.03 & 0.07 & 0.07 & 0.04 & 0.03 \\
\hline $\mathrm{H}_{2} \mathrm{O}$ & 4.30 & 4.28 & 4.09 & 3.25 & 3.48 & 3.37 & 3.64 & 4.08 & 4.04 & 3.83 & 2.94 & 5.05 & 3.44 \\
\hline Total & 100.00 & 100.00 & 100.00 & 100.00 & 100.00 & 100.00 & 100.00 & 100.00 & 100.00 & 100.00 & 100.00 & 100.00 & 100.00 \\
\hline
\end{tabular}


Table 3.11: Biotite composition (4/9).

\begin{tabular}{|c|c|c|c|c|c|c|c|c|c|c|c|c|c|}
\hline Sample & PI-41 & PI-41 & PI-41 & PI-41 & PI-41 & PI-41 & PI-41 & PI-41 & PI-41 & $\begin{array}{c}\text { NI-V- } \\
86 \mathrm{~A}\end{array}$ & $\begin{array}{c}\text { NI-V- } \\
86 \mathrm{~A}\end{array}$ & $\begin{array}{c}\text { NI-V- } \\
86 \mathrm{~A}\end{array}$ & $\begin{array}{c}\text { NI-V- } \\
86 \mathrm{~A}\end{array}$ \\
\hline Analysis & 12 & 13 & 14 & 15 & 16 & 17 & 18 & 19 & 20 & 1 & 2 & 3 & 4 \\
\hline Unit & $\begin{array}{c}\text { RM } \\
\text { tonalite }\end{array}$ & $\begin{array}{c}\mathrm{RM} \\
\text { tonalite }\end{array}$ & $\begin{array}{c}\text { RM } \\
\text { tonalite }\end{array}$ & $\begin{array}{c}\text { RM } \\
\text { tonalite }\end{array}$ & $\begin{array}{c}\mathrm{RM} \\
\text { tonalite }\end{array}$ & $\begin{array}{c}\text { RM } \\
\text { tonalite }\end{array}$ & $\begin{array}{c}\mathrm{RM} \\
\text { tonalite }\end{array}$ & $\begin{array}{c}\mathrm{RM} \\
\text { tonalite }\end{array}$ & $\begin{array}{c}\mathrm{RM} \\
\text { tonalite }\end{array}$ & $\begin{array}{c}\text { MA } \\
\text { tonalite }\end{array}$ & $\begin{array}{c}\text { MA } \\
\text { tonalite }\end{array}$ & $\begin{array}{c}\text { MA } \\
\text { tonalite }\end{array}$ & $\begin{array}{c}\text { MA } \\
\text { tonalite }\end{array}$ \\
\hline $\mathrm{SiO}_{2}$ & 35.70 & 35.60 & 35.23 & 34.86 & 34.94 & 34.33 & 34.61 & 35.04 & 35.64 & 35.87 & 35.58 & 34.73 & 34.93 \\
\hline $\mathrm{Al}_{2} \mathrm{O}_{3}$ & 16.53 & 16.24 & 15.97 & 15.80 & 15.62 & 15.91 & 16.38 & 15.82 & 15.81 & 18.10 & 17.95 & 17.50 & 17.31 \\
\hline $\mathrm{FeO}$ & 24.88 & 23.90 & 24.64 & 26.93 & 27.49 & 27.18 & 27.66 & 27.58 & 26.59 & 21.04 & 21.33 & 20.38 & 21.09 \\
\hline $\mathrm{TiO}_{2}$ & 1.28 & 1.94 & 2.10 & 2.07 & 2.18 & 1.42 & 1.48 & 1.62 & 1.35 & 1.92 & 1.73 & 1.99 & 1.68 \\
\hline $\mathrm{MnO}$ & 0.37 & 0.32 & 0.31 & 0.38 & 0.34 & 0.41 & 0.43 & 0.25 & 0.32 & 0.26 & 0.09 & 0.13 & 0.05 \\
\hline $\mathrm{MgO}$ & 7.91 & 7.54 & 7.44 & 6.11 & 6.04 & 6.27 & 6.21 & 6.36 & 6.37 & 9.61 & 9.91 & 9.97 & 9.65 \\
\hline $\mathrm{CaO}$ & 0.08 & 0.08 & 0.06 & 0.04 & 0.04 & 0.09 & 0.08 & 0.15 & 0.09 & 0.01 & 0.04 & 0.21 & 0.12 \\
\hline $\mathrm{Na}_{2} \mathrm{O}$ & 0.06 & 0.08 & 0.09 & 0.05 & 0.03 & 0.04 & 0.05 & 0.01 & 0.04 & 0.08 & 0.10 & 0.11 & 0.11 \\
\hline $\mathrm{K}_{2} \mathrm{O}$ & 9.34 & 9.28 & 9.47 & 9.48 & 9.41 & 9.30 & 9.24 & 8.86 & 9.48 & 9.84 & 9.53 & 8.47 & 8.52 \\
\hline $\mathrm{BaO}$ & 0.15 & 0.24 & 0.14 & 0.11 & 0.11 & 0.11 & 0.07 & 0.04 & 0.02 & 0.05 & 0.15 & 0.15 & 0.05 \\
\hline $\mathrm{V}_{2} \mathrm{O}_{3}$ & 0.16 & 0.15 & 0.06 & 0.06 & 0.02 & 0.03 & 0.08 & 0.02 & 0.04 & 0.07 & 0.00 & 0.05 & 0.03 \\
\hline $\mathrm{F}$ & 0.56 & 0.67 & 0.46 & 0.44 & 0.41 & 0.39 & 0.51 & 0.42 & 0.48 & 0.22 & 0.27 & 0.22 & 0.19 \\
\hline $\mathrm{Cl}$ & 0.03 & 0.04 & 0.04 & 0.05 & 0.07 & 0.08 & 0.05 & 0.03 & 0.02 & 0.01 & 0.02 & 0.03 & 0.01 \\
\hline $\mathrm{H}_{2} \mathrm{O}$ & 3.21 & 4.23 & 4.18 & 3.82 & 3.49 & 4.62 & 3.38 & 3.99 & 3.97 & 3.02 & 3.43 & 6.18 & 6.34 \\
\hline Total & 100.00 & 100.00 & 100.00 & 100.00 & 100.00 & 100.00 & 100.00 & 100.00 & 100.00 & 100.00 & 100.00 & 100.00 & 100.00 \\
\hline
\end{tabular}


Table 3.12: Biotite composition (5/9).

\begin{tabular}{|c|c|c|c|c|c|c|c|c|c|c|c|c|c|}
\hline Sample & $\begin{array}{c}\text { NI-V- } \\
86 \mathrm{~A}\end{array}$ & $\begin{array}{c}\text { NI-V- } \\
86 \mathrm{~A}\end{array}$ & $\begin{array}{c}\text { NI-VII- } \\
38\end{array}$ & $\begin{array}{c}\text { NI-VII- } \\
38\end{array}$ & $\begin{array}{c}\text { NI-VII- } \\
38\end{array}$ & $\begin{array}{c}\text { NI-VII- } \\
38\end{array}$ & $\begin{array}{c}\text { NI-VII- } \\
38\end{array}$ & $\begin{array}{c}\text { NI-VII- } \\
38\end{array}$ & $\begin{array}{c}\text { NI-VII- } \\
38\end{array}$ & $\begin{array}{c}\text { NI-VII- } \\
38\end{array}$ & $\begin{array}{c}\text { NI-VII- } \\
38\end{array}$ & $\begin{array}{c}\text { NI-VII- } \\
38\end{array}$ & NI-V-99 \\
\hline Analysis & 5 & 7 & 1 & 2 & 3 & 4 & 5 & 6 & 7 & 8 & 9 & 10 & 2 \\
\hline Unit & $\begin{array}{c}\text { MA } \\
\text { tonalite }\end{array}$ & $\begin{array}{c}\text { MA } \\
\text { tonalite }\end{array}$ & $\begin{array}{c}\text { CQ } \\
\text { tonalite }\end{array}$ & $\begin{array}{c}\text { CQ } \\
\text { tonalite }\end{array}$ & $\begin{array}{c}\text { CQ } \\
\text { tonalite }\end{array}$ & $\begin{array}{c}\text { CQ } \\
\text { tonalite }\end{array}$ & $\begin{array}{c}\text { CQ } \\
\text { tonalite }\end{array}$ & $\begin{array}{c}\mathrm{CQ} \\
\text { tonalite }\end{array}$ & $\begin{array}{c}\text { CQ } \\
\text { tonalite }\end{array}$ & $\begin{array}{c}\text { CQ } \\
\text { tonalite }\end{array}$ & $\begin{array}{c}\mathrm{CQ} \\
\text { tonalite }\end{array}$ & $\begin{array}{c}\mathrm{CQ} \\
\text { tonalite }\end{array}$ & $\begin{array}{c}\text { MA } \\
\text { tonalite }\end{array}$ \\
\hline $\mathrm{SiO}_{2}$ & 35.13 & 35.62 & 35.88 & 36.07 & 36.05 & 35.93 & 35.94 & 35.37 & 35.89 & 35.56 & 35.37 & 35.85 & 34.46 \\
\hline $\mathrm{Al}_{2} \mathrm{O}_{3}$ & 17.91 & 17.96 & 18.41 & 17.81 & 18.06 & 17.94 & 17.98 & 17.68 & 17.84 & 17.81 & 17.95 & 18.15 & 17.95 \\
\hline $\mathrm{FeO}$ & 20.45 & 20.78 & 20.24 & 20.74 & 20.37 & 20.33 & 20.61 & 20.48 & 19.91 & 20.80 & 20.63 & 20.42 & 22.41 \\
\hline $\mathrm{TiO}_{2}$ & 1.91 & 1.92 & 1.48 & 1.78 & 2.04 & 1.53 & 2.04 & 2.14 & 1.93 & 1.50 & 1.74 & 1.60 & 1.94 \\
\hline $\mathrm{MnO}$ & 0.03 & 0.24 & 0.38 & 0.42 & 0.39 & 0.46 & 0.38 & 0.38 & 0.25 & 0.41 & 0.35 & 0.37 & 0.15 \\
\hline $\mathrm{MgO}$ & 9.25 & 9.44 & 9.50 & 9.17 & 9.32 & 9.34 & 9.26 & 9.12 & 9.25 & 9.23 & 8.86 & 9.08 & 8.91 \\
\hline $\mathrm{CaO}$ & 0.00 & 0.04 & 0.05 & 0.05 & 0.07 & 0.04 & 0.00 & 0.03 & 0.00 & 0.05 & 0.19 & 0.00 & 0.09 \\
\hline $\mathrm{Na}_{2} \mathrm{O}$ & 0.07 & 0.10 & 0.04 & 0.06 & 0.03 & 0.07 & 0.10 & 0.05 & 0.05 & 0.12 & 0.05 & 0.02 & 0.06 \\
\hline $\mathrm{K}_{2} \mathrm{O}$ & 9.95 & 9.81 & 9.44 & 9.78 & 9.84 & 9.86 & 9.73 & 9.81 & 9.91 & 9.60 & 9.22 & 9.81 & 8.07 \\
\hline $\mathrm{BaO}$ & 0.10 & 0.02 & 0.11 & 0.00 & 0.00 & 0.00 & 0.00 & 0.10 & 0.03 & 0.00 & 0.08 & 0.03 & 0.27 \\
\hline $\mathrm{V}_{2} \mathrm{O}_{3}$ & 0.07 & 0.04 & 0.09 & 0.04 & 0.06 & 0.04 & 0.03 & 0.09 & 0.07 & 0.06 & 0.02 & 0.07 & 0.01 \\
\hline $\mathrm{F}$ & 0.27 & 0.34 & 0.30 & 0.38 & 0.28 & 0.29 & 0.41 & 0.25 & 0.39 & 0.38 & 0.40 & 0.32 & 0.49 \\
\hline $\mathrm{Cl}$ & 0.02 & 0.02 & 0.04 & 0.03 & 0.00 & 0.03 & 0.00 & 0.01 & 0.00 & 0.03 & 0.00 & 0.00 & 0.02 \\
\hline $\mathrm{H}_{2} \mathrm{O}$ & 4.96 & 3.83 & 4.18 & 3.85 & 3.61 & 4.28 & 3.69 & 4.60 & 4.65 & 4.62 & 5.32 & 4.43 & 5.37 \\
\hline Total & 100.00 & 100.00 & 100.00 & 100.00 & 100.00 & 100.00 & 100.00 & 100.00 & 100.00 & 100.00 & 100.00 & 100.00 & 100.00 \\
\hline
\end{tabular}


Table 3.13: Biotite composition (6/9).

\begin{tabular}{|c|c|c|c|c|c|c|c|c|c|c|c|c|c|}
\hline Sample & NI-V-99 & NI-V-90 & NI-V-90 & NI-V-90 & NI-V-90 & NI-V-90 & PI-25 & PI-25 & PI-25 & PI-25 & PI-25 & PI-25 & PI-25 \\
\hline Analysis & 3 & 1 & 2 & 3 & 4 & 5 & 1 & 2 & 3 & 4 & 5 & 6 & 7 \\
\hline Unit & $\begin{array}{c}\text { MA } \\
\text { tonalite }\end{array}$ & $\begin{array}{c}\text { MA } \\
\text { tonalite }\end{array}$ & $\begin{array}{c}\text { MA } \\
\text { tonalite }\end{array}$ & $\begin{array}{c}\text { MA } \\
\text { tonalite }\end{array}$ & $\begin{array}{c}\text { MA } \\
\text { tonalite }\end{array}$ & $\begin{array}{c}\text { MA } \\
\text { tonalite }\end{array}$ & $\begin{array}{c}\mathrm{RM} \\
\text { tonalite }\end{array}$ & $\begin{array}{c}\mathrm{RM} \\
\text { tonalite }\end{array}$ & $\begin{array}{c}\mathrm{RM} \\
\text { tonalite }\end{array}$ & $\begin{array}{c}\mathrm{RM} \\
\text { tonalite }\end{array}$ & $\begin{array}{c}\mathrm{RM} \\
\text { tonalite }\end{array}$ & $\begin{array}{c}\mathrm{RM} \\
\text { tonalite }\end{array}$ & $\begin{array}{c}\mathrm{RM} \\
\text { tonalite }\end{array}$ \\
\hline $\mathrm{SiO}_{2}$ & 34.97 & 34.59 & 34.37 & 34.54 & 33.32 & 34.02 & 37.01 & 37.26 & 37.34 & 37.54 & 37.26 & 37.57 & 37.45 \\
\hline $\mathrm{Al}_{2} \mathrm{O}_{3}$ & 18.82 & 19.17 & 20.22 & 19.35 & 20.01 & 18.40 & 17.13 & 17.09 & 17.11 & 17.06 & 17.11 & 17.20 & 17.21 \\
\hline $\mathrm{FeO}$ & 22.10 & 26.96 & 25.37 & 26.75 & 26.57 & 26.44 & 18.14 & 18.31 & 18.34 & 18.53 & 18.40 & 18.98 & 18.26 \\
\hline $\mathrm{TiO}_{2}$ & 1.53 & 2.12 & 2.21 & 2.22 & 1.79 & 2.37 & 2.64 & 2.36 & 2.31 & 2.56 & 2.36 & 2.55 & 2.26 \\
\hline $\mathrm{MnO}$ & 0.10 & 0.16 & 0.02 & 0.07 & 0.06 & 0.02 & 0.54 & 0.60 & 0.55 & 0.55 & 0.60 & 0.63 & 0.54 \\
\hline $\mathrm{MgO}$ & 8.14 & 4.80 & 4.95 & 4.68 & 4.80 & 4.52 & 11.47 & 11.29 & 11.31 & 11.28 & 11.51 & 11.35 & 11.63 \\
\hline $\mathrm{CaO}$ & 0.05 & 0.07 & 0.22 & 0.11 & 0.20 & 0.05 & 0.02 & 0.05 & 0.02 & 0.02 & 0.00 & 0.00 & 0.06 \\
\hline $\mathrm{Na}_{2} \mathrm{O}$ & 0.04 & 0.11 & 0.09 & 0.07 & 0.09 & 0.03 & 0.06 & 0.05 & 0.07 & 0.06 & 0.03 & 0.06 & 0.05 \\
\hline $\mathrm{K}_{2} \mathrm{O}$ & 8.70 & 9.11 & 6.93 & 8.54 & 7.22 & 9.08 & 9.93 & 9.46 & 9.82 & 9.83 & 9.87 & 10.17 & 9.84 \\
\hline $\mathrm{BaO}$ & 0.23 & 0.26 & 0.21 & 0.09 & 0.07 & 0.20 & 0.07 & 0.01 & 0.22 & 0.00 & 0.27 & 0.14 & 0.08 \\
\hline $\mathrm{V}_{2} \mathrm{O}_{3}$ & 0.01 & 0.00 & 0.01 & 0.00 & 0.05 & 0.06 & 0.04 & 0.05 & 0.00 & 0.04 & 0.12 & 0.05 & 0.04 \\
\hline $\mathrm{F}$ & 0.49 & 0.19 & 0.14 & 0.21 & 0.18 & 0.22 & 0.77 & 0.76 & 0.70 & 0.70 & 0.63 & 0.62 & 0.71 \\
\hline $\mathrm{Cl}$ & 0.03 & 0.01 & 0.03 & 0.02 & 0.03 & 0.02 & 0.09 & 0.09 & 0.07 & 0.08 & 0.03 & 0.10 & 0.09 \\
\hline $\mathrm{H}_{2} \mathrm{O}$ & 5.01 & 2.54 & 5.32 & 3.45 & 5.70 & 4.67 & 2.42 & 2.95 & 2.45 & 2.07 & 2.09 & 0.87 & 2.11 \\
\hline Total & 100.00 & 100.00 & 100.00 & 100.00 & 100.00 & 100.00 & 100.00 & 100.00 & 100.00 & 100.00 & 100.00 & 100.00 & 100.00 \\
\hline
\end{tabular}


Table 3.14: Biotite composition (7/9).

\begin{tabular}{|c|c|c|c|c|c|c|c|c|c|c|c|c|c|}
\hline Sample & PI-25 & PI-25 & PI-25 & PI-25 & PI-25 & PI-25 & PI-25 & PI-25 & PI-25 & PI-25 & PI-25 & PI-25 & PI-25 \\
\hline Analysis & C1.8 & $\mathrm{C} 2.8$ & 9 & 10 & 11 & 12 & 13 & 14 & 15 & 16 & 17 & 18 & 19 \\
\hline Unit & $\begin{array}{c}\mathrm{RM} \\
\text { tonalite }\end{array}$ & $\begin{array}{c}\mathrm{RM} \\
\text { tonalite }\end{array}$ & $\begin{array}{c}\mathrm{RM} \\
\text { tonalite }\end{array}$ & $\begin{array}{c}\mathrm{RM} \\
\text { tonalite }\end{array}$ & $\begin{array}{c}\mathrm{RM} \\
\text { tonalite }\end{array}$ & $\begin{array}{c}\mathrm{RM} \\
\text { tonalite }\end{array}$ & $\begin{array}{c}\mathrm{RM} \\
\text { tonalite }\end{array}$ & $\begin{array}{c}\mathrm{RM} \\
\text { tonalite }\end{array}$ & $\begin{array}{c}\mathrm{RM} \\
\text { tonalite }\end{array}$ & $\begin{array}{c}\mathrm{RM} \\
\text { tonalite }\end{array}$ & $\begin{array}{c}\mathrm{RM} \\
\text { tonalite }\end{array}$ & $\begin{array}{c}\mathrm{RM} \\
\text { tonalite }\end{array}$ & $\begin{array}{c}\mathrm{RM} \\
\text { tonalite }\end{array}$ \\
\hline $\mathrm{SiO}_{2}$ & 37.11 & 37.21 & 37.62 & 37.47 & 37.52 & 37.23 & 36.95 & 37.30 & 37.43 & 37.52 & 37.00 & 36.37 & 36.50 \\
\hline $\mathrm{Al}_{2} \mathrm{O}_{3}$ & 17.29 & 16.92 & 17.01 & 17.05 & 17.14 & 17.13 & 16.77 & 16.66 & 17.02 & 16.83 & 17.39 & 17.06 & 17.06 \\
\hline $\mathrm{FeO}$ & 18.56 & 16.51 & 16.35 & 16.78 & 16.84 & 17.15 & 17.21 & 17.40 & 17.17 & 17.15 & 20.66 & 21.33 & 21.24 \\
\hline $\mathrm{TiO}_{2}$ & 2.47 & 2.28 & 3.04 & 2.32 & 2.04 & 2.01 & 2.07 & 2.06 & 2.06 & 1.91 & 2.60 & 3.04 & 2.46 \\
\hline $\mathrm{MnO}$ & 0.78 & 0.38 & 0.69 & 0.66 & 0.65 & 0.65 & 0.46 & 0.53 & 0.55 & 0.54 & 0.52 & 0.51 & 0.58 \\
\hline $\mathrm{MgO}$ & 11.34 & 13.19 & 12.74 & 12.81 & 12.63 & 12.73 & 12.43 & 12.83 & 12.92 & 13.33 & 9.29 & 9.41 & 9.42 \\
\hline $\mathrm{CaO}$ & 0.02 & 0.01 & 0.25 & 0.02 & 0.03 & 0.02 & 0.23 & 0.03 & 0.00 & 0.04 & 0.00 & 0.00 & 0.00 \\
\hline $\mathrm{Na}_{2} \mathrm{O}$ & 0.05 & 0.06 & 0.03 & 0.05 & 0.05 & 0.06 & 0.08 & 0.09 & 0.07 & 0.08 & 0.06 & 0.03 & 0.07 \\
\hline $\mathrm{K}_{2} \mathrm{O}$ & 9.68 & 9.89 & 9.66 & 9.87 & 9.73 & 10.04 & 9.54 & 9.92 & 10.01 & 9.80 & 9.85 & 9.92 & 9.91 \\
\hline $\mathrm{BaO}$ & 0.04 & 0.00 & 0.12 & 0.12 & 0.11 & 0.05 & 0.07 & 0.12 & 0.00 & 0.25 & 0.07 & 0.21 & 0.08 \\
\hline $\mathrm{V}_{2} \mathrm{O}_{3}$ & 0.11 & 0.00 & 0.00 & 0.05 & 0.03 & 0.04 & 0.08 & 0.07 & 0.05 & 0.03 & 0.17 & 0.09 & 0.08 \\
\hline $\mathrm{F}$ & 0.64 & 0.82 & 0.92 & 0.67 & 0.78 & 0.87 & 0.89 & 0.82 & 0.72 & 0.66 & 0.56 & 0.54 & 0.49 \\
\hline $\mathrm{Cl}$ & 0.08 & 0.09 & 0.09 & 0.09 & 0.05 & 0.09 & 0.05 & 0.11 & 0.07 & 0.08 & 0.09 & 0.06 & 0.10 \\
\hline $\mathrm{H}_{2} \mathrm{O}$ & 2.11 & 3.01 & 1.88 & 2.34 & 2.76 & 2.33 & 3.56 & 2.45 & 2.26 & 2.08 & 2.00 & 1.67 & 2.24 \\
\hline Total & 100.00 & 100.00 & 100.00 & 100.00 & 100.00 & 100.00 & 100.00 & 100.00 & 100.00 & 100.00 & 100.00 & 100.00 & 100.00 \\
\hline
\end{tabular}


Table 3.15: Biotite composition (8/9).

\begin{tabular}{|c|c|c|c|c|c|c|c|c|c|c|c|c|c|}
\hline Sample & PI-25 & PI-25 & PI-35 & PI-35 & PI-35 & PI-35 & PI-35 & PI-35 & PI-35 & PI-35 & PI-35 & PI-35 & PI-35 \\
\hline Analysis & 20 & 21 & 1 & 2 & 3 & 4 & 6 & 7 & 8 & 9 & 10 & 11 & 12 \\
\hline Unit & $\begin{array}{c}\mathrm{RM} \\
\text { tonalite }\end{array}$ & $\begin{array}{c}\mathrm{RM} \\
\text { tonalite }\end{array}$ & $\begin{array}{c}\text { MA } \\
\text { tonalite }\end{array}$ & $\begin{array}{c}\text { MA } \\
\text { tonalite }\end{array}$ & $\begin{array}{c}\text { MA } \\
\text { tonalite }\end{array}$ & $\begin{array}{c}\text { MA } \\
\text { tonalite }\end{array}$ & $\begin{array}{c}\text { MA } \\
\text { tonalite }\end{array}$ & $\begin{array}{c}\text { MA } \\
\text { tonalite }\end{array}$ & $\begin{array}{c}\text { MA } \\
\text { tonalite }\end{array}$ & $\begin{array}{c}\text { MA } \\
\text { tonalite }\end{array}$ & $\begin{array}{c}\text { MA } \\
\text { tonalite }\end{array}$ & $\begin{array}{c}\text { MA } \\
\text { tonalite }\end{array}$ & $\begin{array}{c}\text { MA } \\
\text { tonalite }\end{array}$ \\
\hline $\mathrm{SiO}_{2}$ & 36.51 & 36.77 & 34.97 & 35.48 & 34.55 & 34.89 & 35.29 & 35.51 & 35.47 & 35.00 & 35.10 & 35.45 & 35.25 \\
\hline $\mathrm{Al}_{2} \mathrm{O}_{3}$ & 16.67 & 17.23 & 17.88 & 18.14 & 17.95 & 17.73 & 18.03 & 18.14 & 18.60 & 18.11 & 18.31 & 17.83 & 18.17 \\
\hline $\mathrm{FeO}$ & 21.17 & 21.51 & 25.34 & 25.62 & 27.40 & 25.28 & 24.97 & 24.59 & 24.41 & 25.09 & 24.96 & 25.76 & 25.46 \\
\hline $\mathrm{TiO}_{2}$ & 2.86 & 2.48 & 2.08 & 2.28 & 2.18 & 1.88 & 2.22 & 1.96 & 2.07 & 2.31 & 3.08 & 2.33 & 2.44 \\
\hline $\mathrm{MnO}$ & 0.74 & 0.62 & 0.46 & 0.35 & 0.29 & 0.28 & 0.29 & 0.29 & 0.32 & 0.41 & 0.20 & 0.28 & 0.35 \\
\hline $\mathrm{MgO}$ & 9.46 & 9.57 & 6.72 & 6.69 & 6.21 & 6.59 & 6.46 & 6.65 & 6.33 & 6.41 & 6.50 & 6.62 & 6.37 \\
\hline $\mathrm{CaO}$ & 0.01 & 0.01 & 0.00 & 0.02 & 0.09 & 0.06 & 0.01 & 0.06 & 0.01 & 0.00 & 0.00 & 0.02 & 0.05 \\
\hline $\mathrm{Na}_{2} \mathrm{O}$ & 0.02 & 0.05 & 0.09 & 0.06 & 0.09 & 0.08 & 0.08 & 0.21 & 0.06 & 0.14 & 0.03 & 0.07 & 0.09 \\
\hline $\mathrm{K}_{2} \mathrm{O}$ & 9.62 & 9.78 & 9.16 & 9.14 & 8.77 & 9.04 & 9.43 & 9.52 & 9.26 & 9.12 & 9.22 & 9.01 & 9.24 \\
\hline $\mathrm{BaO}$ & 0.06 & 0.00 & 0.20 & 0.07 & 0.12 & 0.07 & 0.05 & 0.03 & 0.06 & 0.23 & 0.06 & 0.14 & 0.23 \\
\hline $\mathrm{V}_{2} \mathrm{O}_{3}$ & 0.04 & 0.00 & 0.05 & 0.04 & 0.05 & 0.00 & 0.00 & 0.09 & 0.10 & 0.14 & 0.11 & 0.00 & 0.06 \\
\hline $\mathrm{F}$ & 0.38 & 0.57 & 0.09 & 0.08 & 0.05 & 0.09 & 0.11 & 0.10 & 0.12 & 0.00 & 0.13 & 0.02 & 0.07 \\
\hline $\mathrm{Cl}$ & 0.06 & 0.10 & 0.12 & 0.14 & 0.13 & 0.10 & 0.16 & 0.22 & 0.14 & 0.14 & 0.10 & 0.14 & 0.11 \\
\hline $\mathrm{H}_{2} \mathrm{O}$ & 2.58 & 1.58 & 2.92 & 1.97 & 2.16 & 3.98 & 3.00 & 2.72 & 3.14 & 2.93 & 2.29 & 2.38 & 2.16 \\
\hline Total & 100.00 & 100.00 & 100.00 & 100.00 & 100.00 & 100.00 & 100.00 & 100.00 & 100.00 & 100.00 & 100.00 & 100.00 & 100.00 \\
\hline
\end{tabular}


Table 3.16: Biotite composition (9/9).

\begin{tabular}{|c|c|c|c|c|c|c|c|c|c|c|c|}
\hline Sample & PI-35 & PI-35 & PI-35 & PI-35 & PI-35 & PI-35 & PI-35 & PI-35 & PI-35 & PI-35 & PI-35 \\
\hline Analysis & 13 & 14 & 15 & 16 & 17 & 18 & 19 & 20 & 21 & 22 & 23 \\
\hline Unit & $\begin{array}{c}\text { MA } \\
\text { tonalite }\end{array}$ & $\begin{array}{c}\text { MA } \\
\text { tonalite }\end{array}$ & $\begin{array}{c}\text { MA } \\
\text { tonalite }\end{array}$ & $\begin{array}{c}\text { MA } \\
\text { tonalite }\end{array}$ & $\begin{array}{c}\text { MA } \\
\text { tonalite }\end{array}$ & $\begin{array}{c}\text { MA } \\
\text { tonalite }\end{array}$ & $\begin{array}{c}\text { MA } \\
\text { tonalite }\end{array}$ & $\begin{array}{c}\text { MA } \\
\text { tonalite }\end{array}$ & $\begin{array}{c}\text { MA } \\
\text { tonalite }\end{array}$ & $\begin{array}{c}\text { MA } \\
\text { tonalite }\end{array}$ & $\begin{array}{c}\text { MA } \\
\text { tonalite }\end{array}$ \\
\hline $\mathrm{SiO}_{2}$ & 35.40 & 35.64 & 35.62 & 34.74 & 35.19 & 35.62 & 35.61 & 35.57 & 35.15 & 35.36 & 34.91 \\
\hline $\mathrm{Al}_{2} \mathrm{O}_{3}$ & 18.62 & 18.26 & 17.96 & 18.10 & 17.88 & 18.15 & 18.15 & 18.13 & 18.18 & 18.19 & 18.09 \\
\hline $\mathrm{MnO}$ & 0.35 & 0.29 & 0.43 & 0.34 & 0.28 & 0.25 & 0.24 & 0.23 & 0.38 & 0.40 & 0.37 \\
\hline $\mathrm{MgO}$ & 6.66 & 6.54 & 6.44 & 6.49 & 6.59 & 6.76 & 6.65 & 6.57 & 6.46 & 6.56 & 6.44 \\
\hline $\mathrm{CaO}$ & 0.05 & 0.02 & 0.00 & 0.05 & 0.00 & 0.00 & 0.02 & 0.05 & 0.00 & 0.01 & 0.05 \\
\hline $\mathrm{Na}_{2} \mathrm{O}$ & 0.01 & 0.09 & 0.05 & 0.05 & 0.04 & 0.08 & 0.07 & 0.02 & 0.00 & 0.06 & 0.02 \\
\hline $\mathrm{F}$ & 0.09 & 0.13 & 0.15 & 0.02 & 0.05 & 0.00 & 0.11 & 0.08 & 0.07 & 0.04 & 0.11 \\
\hline $\mathrm{Cl}$ & 0.10 & 0.14 & 0.11 & 0.13 & 0.13 & 0.13 & 0.12 & 0.11 & 0.13 & 0.11 & 0.13 \\
\hline $\mathrm{H}_{2} \mathrm{O}$ & 3.14 & 2.49 & 2.74 & 2.76 & 2.88 & 1.94 & 2.60 & 2.18 & 2.40 & 2.53 & 3.40 \\
\hline Total & 100.00 & 100.00 & 100.00 & 100.00 & 100.00 & 100.00 & 100.00 & 100.00 & 100.00 & 100.00 & 100.00 \\
\hline
\end{tabular}


Table 3.17: Chlorite composition

\begin{tabular}{|c|c|c|c|c|c|c|c|c|c|c|c|c|c|c|c|c|c|c|c|}
\hline Sample & PI15 & PI15 & PI15 & PI15 & PI15 & $\begin{array}{c}\text { NI-V- } \\
86\end{array}$ & $\begin{array}{c}\text { NI-V- } \\
86\end{array}$ & $\begin{array}{c}\text { NI-V- } \\
86\end{array}$ & $\begin{array}{c}\text { NI-V- } \\
86\end{array}$ & $\begin{array}{c}\text { NI-V- } \\
86\end{array}$ & $\begin{array}{c}\text { NI-V- } \\
99\end{array}$ & $\begin{array}{c}\text { NI-V- } \\
99\end{array}$ & $\begin{array}{c}\text { NI-V- } \\
99\end{array}$ & $\begin{array}{c}\text { NI-V- } \\
99\end{array}$ & $\begin{array}{c}\text { NI-V- } \\
99\end{array}$ & $\begin{array}{c}\text { NI-V- } \\
99\end{array}$ & $\begin{array}{c}\text { NI-V- } \\
99\end{array}$ & $\begin{array}{c}\text { NI-V- } \\
99\end{array}$ & $\begin{array}{c}\text { NI-V- } \\
99\end{array}$ \\
\hline Analysis & 1 & 2 & 3 & 4 & 5 & 1 & 2 & 3 & 4 & 5 & 1 & 2 & 3 & 4 & 5 & 6 & 7 & 8 & 9 \\
\hline Unit & $\begin{array}{c}\mathrm{CQ} \\
\text { tonalite }\end{array}$ & $\begin{array}{c}\mathrm{CQ} \\
\text { tonalite }\end{array}$ & $\begin{array}{c}\text { CQ } \\
\text { tonalite }\end{array}$ & $\begin{array}{c}\mathrm{CQ} \\
\text { tonalite }\end{array}$ & $\begin{array}{c}\text { CQ } \\
\text { tonalite }\end{array}$ & $\begin{array}{c}\text { MA } \\
\text { tonalite }\end{array}$ & $\begin{array}{c}\text { MA } \\
\text { tonalite }\end{array}$ & $\begin{array}{c}\text { MA } \\
\text { tonalite }\end{array}$ & $\begin{array}{c}\text { MA } \\
\text { tonalite }\end{array}$ & $\begin{array}{c}\text { MA } \\
\text { tonalite }\end{array}$ & $\begin{array}{c}\text { MA } \\
\text { tonalite }\end{array}$ & $\begin{array}{c}\text { MA } \\
\text { tonalite }\end{array}$ & $\begin{array}{c}\text { MA } \\
\text { tonalite }\end{array}$ & $\begin{array}{c}\text { MA } \\
\text { tonalite }\end{array}$ & $\begin{array}{c}\text { MA } \\
\text { tonalite }\end{array}$ & $\begin{array}{c}\text { MA } \\
\text { tonalite }\end{array}$ & $\begin{array}{c}\text { MA } \\
\text { tonalite }\end{array}$ & $\begin{array}{c}\text { MA } \\
\text { tonalite }\end{array}$ & $\begin{array}{c}\text { MA } \\
\text { tonalite }\end{array}$ \\
\hline $\mathrm{SiO}_{2}$ & 25.39 & 25.46 & 25.13 & 26.27 & 25.84 & 25.81 & 26.46 & 24.35 & 24.52 & 24.64 & 25.52 & 25.21 & 24.60 & 25.03 & 25.39 & 24.91 & 25.07 & 25.30 & 24.22 \\
\hline $\mathrm{Al}_{2} \mathrm{O}_{3}$ & 20.62 & 20.08 & 19.85 & 20.66 & 20.67 & 19.45 & 19.18 & 22.55 & 22.22 & 22.26 & 20.32 & 20.75 & 20.51 & 20.33 & 20.22 & 20.36 & 20.92 & 20.79 & 20.04 \\
\hline $\mathrm{FeO}$ & 30.10 & 29.74 & 29.80 & 29.24 & 29.32 & 29.96 & 30.21 & 27.85 & 27.51 & 28.01 & 30.95 & 31.25 & 31.23 & 31.15 & 31.16 & 30.98 & 31.16 & 30.96 & 30.96 \\
\hline $\mathrm{TiO}_{2}$ & 0.00 & 0.00 & 0.09 & 0.00 & 0.00 & 0.09 & 0.00 & 0.00 & 0.04 & 0.03 & 0.00 & 0.05 & 0.00 & 0.07 & 0.16 & 0.16 & 0.02 & 0.07 & 0.00 \\
\hline $\mathrm{MnO}$ & 0.70 & 0.62 & 0.73 & 0.70 & 0.79 & 0.29 & 0.32 & 0.18 & 0.25 & 0.23 & 0.18 & 0.37 & 0.15 & 0.17 & 0.21 & 0.24 & 0.37 & 0.23 & 0.20 \\
\hline $\mathrm{MgO}$ & 12.66 & 12.68 & 12.31 & 12.61 & 12.72 & 13.93 & 13.52 & 14.42 & 14.77 & 14.38 & 11.60 & 11.76 & 12.09 & 11.70 & 11.85 & 11.80 & 12.06 & 12.08 & 11.50 \\
\hline $\mathrm{CaO}$ & 0.03 & 0.02 & 0.04 & 0.02 & 0.02 & 0.00 & 0.07 & 0.01 & 0.01 & 0.01 & 0.03 & 0.09 & 0.04 & 0.03 & 0.00 & 0.04 & 0.03 & 0.04 & 0.20 \\
\hline $\mathrm{Na}_{2} \mathrm{O}$ & 0.00 & 0.00 & 0.02 & 0.02 & 0.00 & 0.01 & 0.00 & 0.02 & 0.00 & 0.02 & 0.04 & 0.02 & 0.03 & 0.06 & 0.02 & 0.02 & 0.04 & 0.00 & 0.01 \\
\hline $\mathrm{K}_{2} \mathrm{O}$ & 0.05 & 0.07 & 0.07 & 0.53 & 0.16 & 0.00 & 0.01 & 0.01 & 0.00 & 0.03 & 0.07 & 0.00 & 0.00 & 0.08 & 0.01 & 0.01 & 0.02 & 0.00 & 0.06 \\
\hline $\mathrm{BaO}$ & 0.01 & 0.00 & 0.00 & 0.00 & 0.02 & 0.00 & 0.00 & 0.00 & 0.00 & 0.08 & 0.05 & 0.00 & 0.11 & 0.04 & 0.01 & 0.08 & 0.01 & 0.08 & 0.00 \\
\hline $\mathrm{V}_{2} \mathrm{O}_{3}$ & 0.00 & 0.05 & 0.05 & 0.03 & 0.06 & 0.02 & 0.08 & 0.02 & 0.05 & 0.04 & 0.05 & 0.01 & 0.00 & 0.00 & 0.04 & 0.01 & 0.02 & 0.00 & 0.07 \\
\hline $\mathrm{F}$ & 0.08 & 0.00 & 0.02 & 0.15 & 0.00 & 0.00 & 0.00 & 0.00 & 0.00 & 0.05 & 0.07 & 0.09 & 0.05 & 0.06 & 0.07 & 0.00 & 0.00 & 0.04 & 0.00 \\
\hline $\mathrm{Cl}$ & 0.01 & 0.01 & 0.01 & 0.01 & 0.01 & 0.01 & 0.01 & 0.00 & 0.01 & 0.01 & 0.01 & 0.01 & 0.00 & 0.01 & 0.00 & 0.00 & 0.02 & 0.01 & 0.00 \\
\hline $\mathrm{H}_{2} \mathrm{O}$ & 10.39 & 11.28 & 11.89 & 9.82 & 10.40 & 10.43 & 10.17 & 10.58 & 10.63 & 10.25 & 11.14 & 10.46 & 11.20 & 11.31 & 10.90 & 11.39 & 10.27 & 10.43 & 12.75 \\
\hline Total & 100.00 & 100.00 & 100.00 & 100.00 & 100.00 & 100.00 & 100.00 & 100.00 & 100.00 & 100.00 & 100.00 & 100.00 & 100.00 & 100.00 & 100.00 & 100.00 & 100.00 & 100.00 & 100.00 \\
\hline
\end{tabular}




\section{RHYACIAN CRUSTAL EVOLUTION OF NORTHERN BRASÍLIA BELT BASEMENT: CONSTRAINTS FROM GEOCHEMISTRY, GEOCHRONOLOGY AND ISOTOPE DATA}

\subsection{Introduction}

Crustal growth episodes during Earth's history are intimately related to juvenile crust generation, followed by crustal fragments collage and stabilization. This process converges to supercontinent formation, which subsequent fragmentation prompts landmasses dispersion that will further accrete and form another supercontinent, in a cyclical pattern. The existence of collisional orogens from c. 2.1-1.8 Ga worldwide led authors to propose a PaleoMesoproterozoic pre-Rodinia supercontinent, known by several names: Columbia, Atlantica, Nuna (Unrug, 1996; Rogers and Santosh, 2002; Zhao et al., 2006; Evans and Mitchell, 2011).

In northern Brasília Belt (Figure 4.1 and Figure 4.2), basement crops out as a large area of Paleoproterozoic granitic rocks, intrusive in volcano-sedimentary sequences. Available geochronological data suggest this terrane have its formation coeval with a Paleoproterozoic orogeny. This study focuses these granitic rocks, aiming to detail age of crystallization and chemical signature, in order to determine characteristics of the magmatism and compare it with known Paleoproterozoic orogens.

Furthermore, this paper is also an attempt to deepen the discussion about São Francisco craton and Goiás Massif boundaries. The Brasília Belt developed on the western margin of São Fancisco craton, during its convergence towards continental landmasses from Goiás Massif, Amazonian craton and the conjectural Paranapanema craton (Figure 4.1). Although maps, based on gravimetric data, show São Francisco craton borders east of Brasília Belt, it is consensual that sediments from the belt must lay over a basement, which is probably the São Francisco paleoplate extension underneath the thrust and fold belt.

Uphold on this assumption, we discuss the basement rocks cropping out in northern Brasília Belt as a prolongation of the craton, trying to understand the mechanism responsible for Paleoproterozoic granitogenesis.

Moreover, we discuss the meaning of the Goiás Massif. Although some authors state the massif is undoubtedly allochthonous (Pimentel et al., 2000) and Rio Maranhão fault is a suture zone, others differ in opinion and question whether it could be part of São Francisco paleoplate (Cordeiro, 2014; Pereira \& Fuck, 2005; Martins-Neto, 2009, Alvarenga, 2012); 
thereby, the Rio Maranhão fault would represent an intracontinental thrust. We enter this debate just to compare basement in northern Brasília Belt to Campinorte sequence, the Paleoproterozoic window in Goiás Massif.

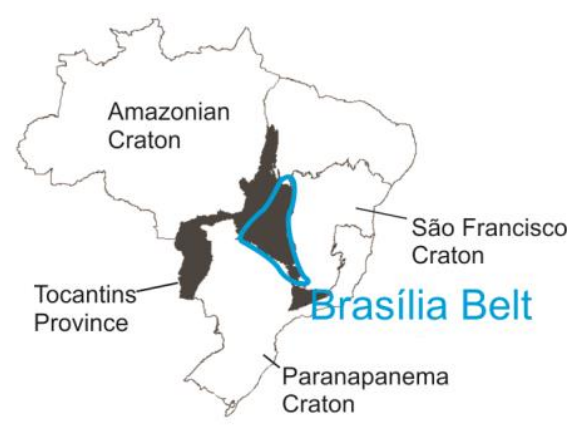

Figure 4.1:Tocantins Province (Almeida et al., 1981)

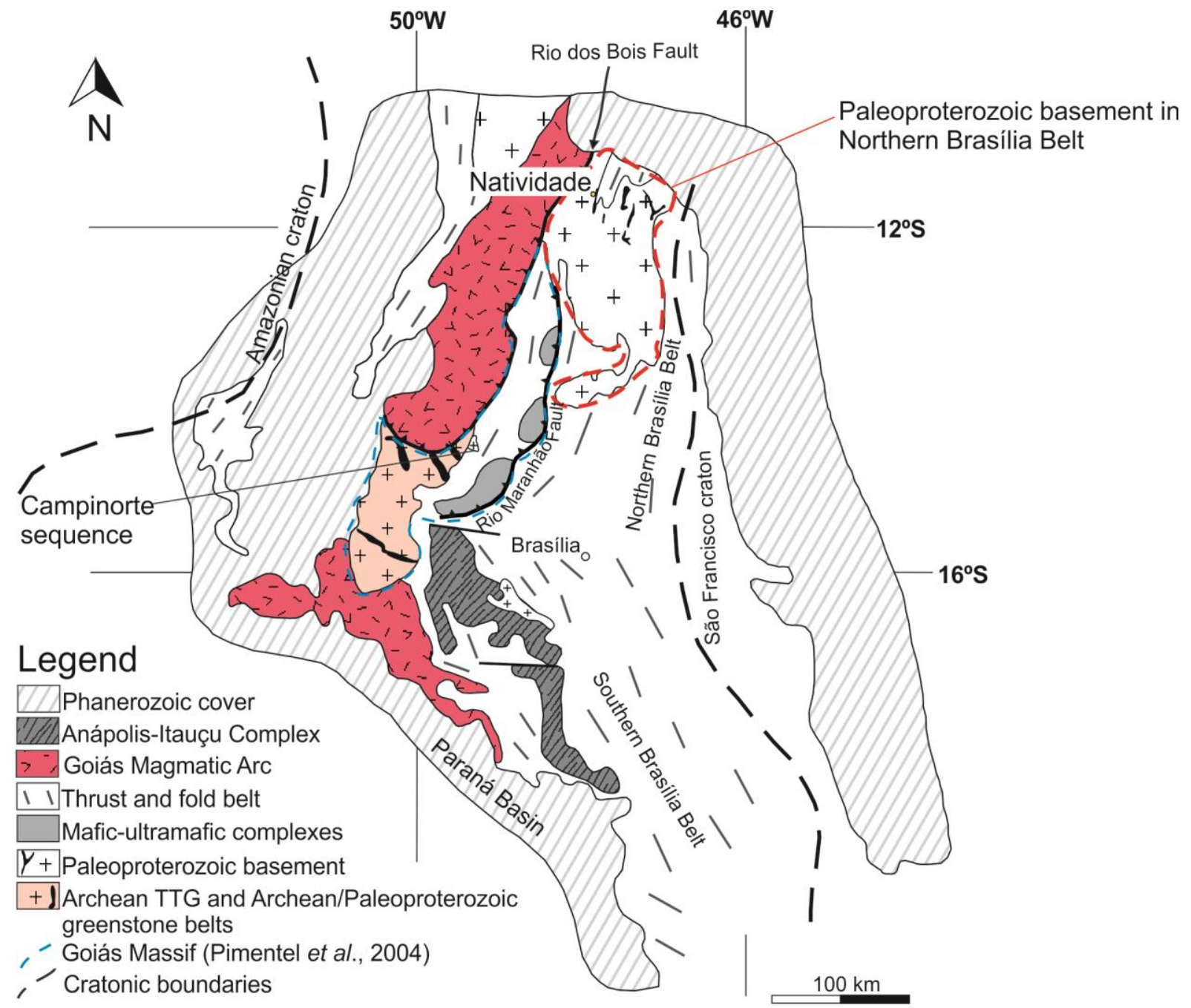

Figure 4.2: Brasília Belt schematic map (Modified from Pimentel et al., 2006; Oliveira et al., 2006). 


\subsection{Geologic Overview}

The Brasília Belt basement in its northern segment may be divided in three domains: the Cavalcante-Arraias domain, the Almas-Conceição do Tocantins domain (Fuck et al., 2014), also known as Almas-Dianópolis Terrane (Correia Filho e Sá, 1980; Costa, 1985; Cruz, 1993), and the Natividade basement (Figure 4.3).

Both Cavalcante-Arraias and Almas-Conceição do Tocantins domains have already been focus of research in the past twenty years, whilst Natividade basement has had no systematic study on its geochemical signature.

Cavalcante-Arraias domain encompasses magmatic rocks with peraluminous character, including muscovite monzogranite, muscovite-biotite monzogranite, tonalite, biotite syenogranite, tourmaline-bearing leucogranites and pegmatites. They are intrusive in graphitic schists and paragneisses from Ticunzal Formation. Graphite-bearing xenoliths and graphite nodules in granites and tonalites from Aurumina suite confirm this relation.

The syn- to late- tectonic character of the intrusions is observed by lit par lit structures, seen as granite injection in foliation planes of Ticunzal Formation. U-Pb zircon data indicate ages from 2.12 to $2.17 \mathrm{Ga}$ (Botelho et al., 2006), and Sm-Nd analysis show negative values of $\varepsilon_{\mathrm{Nd}}(\mathrm{t})$, ranging from -1 to -6 (Fuck et al., 2002; Fuck et al., 2014). $T_{\mathrm{DM}}$ ages are between 2.4 and 2.6 Ga (Fuck et al., 2002).

Aurumina suite is interpreted as derived from crustal melting, responsible for generating peraluminous magmas highly contaminated by sediments. Ticunzal Formation is the oldest unit recognized in the area, and its TDM ages varying between 2.5 to $2.8 \mathrm{Ga}$ led authors to suggest the source of sediments of Ticunzal basin is Archean (Botelho et al., 2006). These authors also believe Aurumina suite has its origin related to melting of sediments from Ticunzal Formation during late orogenic events. Foliation of Aurumina suite strikes NNESSW.

One pluton, the Nova Roma quartz diorite, crops out among Aurumina suite, is similar in age, $2.14 \mathrm{Ga}(\mathrm{U}-\mathrm{Pb}$ in zircon), has $\varepsilon \mathrm{Nd}(\mathrm{t})=-3.9$ and $\mathrm{TDM}=2.48$, but is not peraluminous. Its metaluminous nature and the presence of amphibole do not indicate a petrogenetic relation with Aurumina suite, and made authors individualize it (Alvarenga et al., 2007).

The Almas-Conceição do Tocantins is the northernmost part of the basement, where granitic bodies are intrusive in Riachão do Ouro Group. These bodies consist of isotropic to weakly foliated plutons, with local gneissic banding, displaying either intrusive or faulted contacts with the volcano-sedimentary sequence of Riachão do Ouro. As tonalites, 
trondhjemite and granodiorite are the dominant units, these complexes have been characterized as TTG terranes (Cruz \& Kuyumjian, 1998).

Córrego do Paiol Formation, on the base, and Morro do Carneiro Formation, on the top, constitute the Riachão do Ouro Goup. Córrego Paiol Formation contains basalts, locally pillowed and rare occurences of ultramafic rocks as tremolite schists. Morro do Carneiro Formation is a sequence of sericitic phyllites with carbonaceous rich layers, cherts, quartzites and banded iron formations.

Cruz \& Kuyumjian (1998) divided the granitic plutons in two suites: Suite 1 is metaluminous and has amphibole as its main mafic constituent, while Suite 2 is intrusive in Suite 1 , is peraluminous and has no amphibole, having biotite as the main mafic mineral.

Available U-Pb data in zircon show both suites crystalized around $2.2 \mathrm{Ga} . \varepsilon_{\mathrm{Nd}(\mathrm{t}=2.2)}$ ranges from -4.95 to -0.15 (Cruz, 2001). Although being the same age, Cruz (1993) suggests they probably have distinct sources. Suite 1 is interpreted as melting of ultramafic mantle material and Suite 2 is more likely derived from basalts (Cruz 1993).

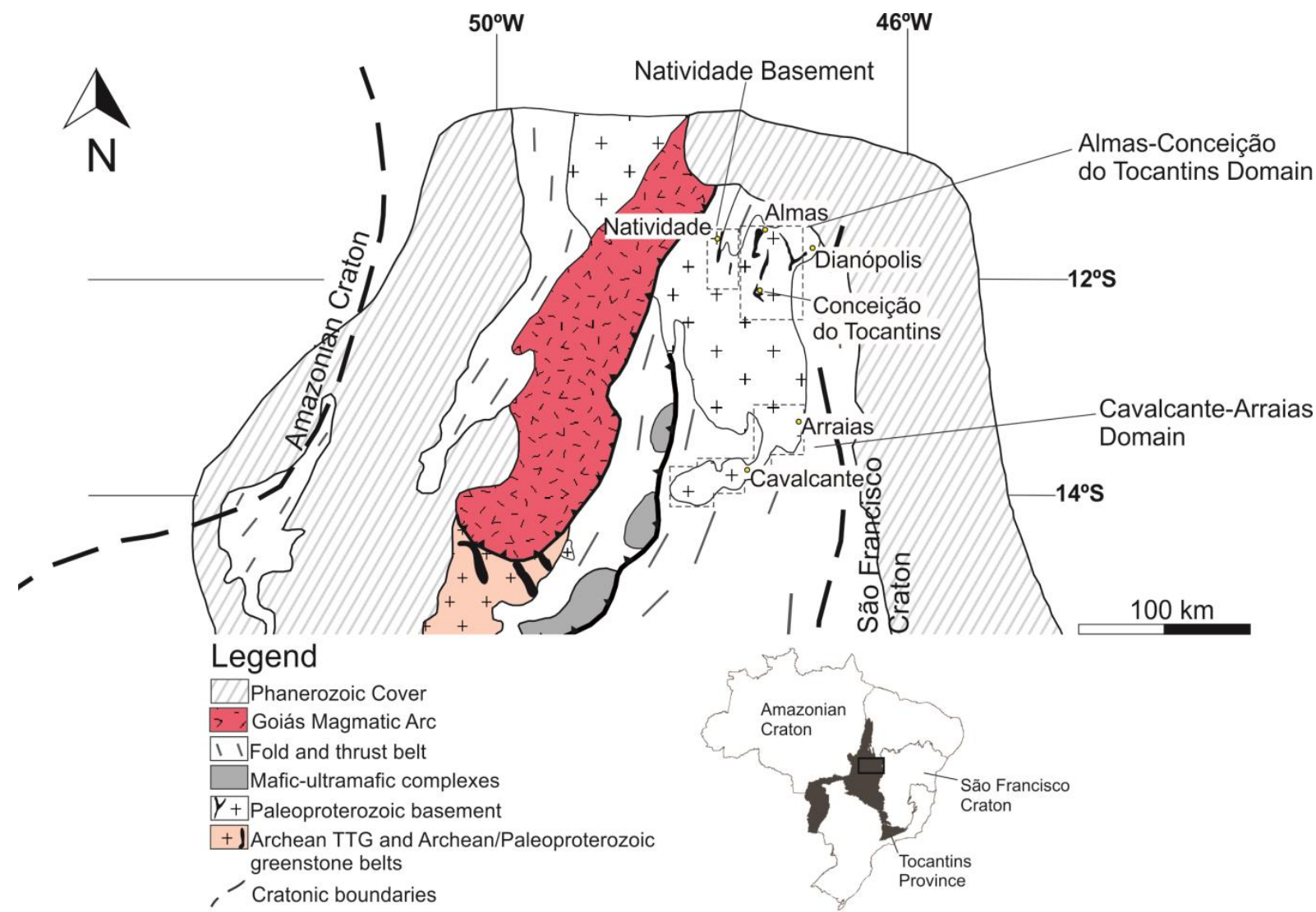

Figure 4.3: Domains within Northern Brasília Belt. Almas-Conceição do Tocantins, Cavalcante-Arrais domains and Natividade basement (Modified from Pimentel et al., 2006; Oliveira et al., 2006).

Cartography between Calcalcante-Arraias and Almas-Conceição do Tocantins domains is unsatisfactory and the nature of the transition between them is still unknown. 
West of Almas-Conceição do Tocantins domain, crops out what we named the Natividade basement, representing Paleoproterozoic rocks around Natividade (Figure 4.4). This nomenclature was chosen to be used during the research, once it is unknown whether these rocks have more similarities with Almas-Conceição do Tocantins domain, with Calcalcante-Arraias domain or if they belong to a completely different block.

\subsection{Geology of Natividade basement}

Rocks in Natividade basement are granites, tonalites and granodiorites intrusive in a volcano-sedimentary sequence named Água Suja (Gorayeb, 1988; Queiroz, 2001). Granitic rocks are divided in five units: Rio do Moleque suite, Manuel Alves suite, Córrego Quati tonalite, Xobó suite and Príncipe Granite (Oliveira, 2012). The volcano-sedimentary sequence presents chemical and clastic sediments as quartzites, pelites, carbonaceous phyllite, gondite chert, banded iron formation and rare volcanic mafic rocks (Figure 4.4). 


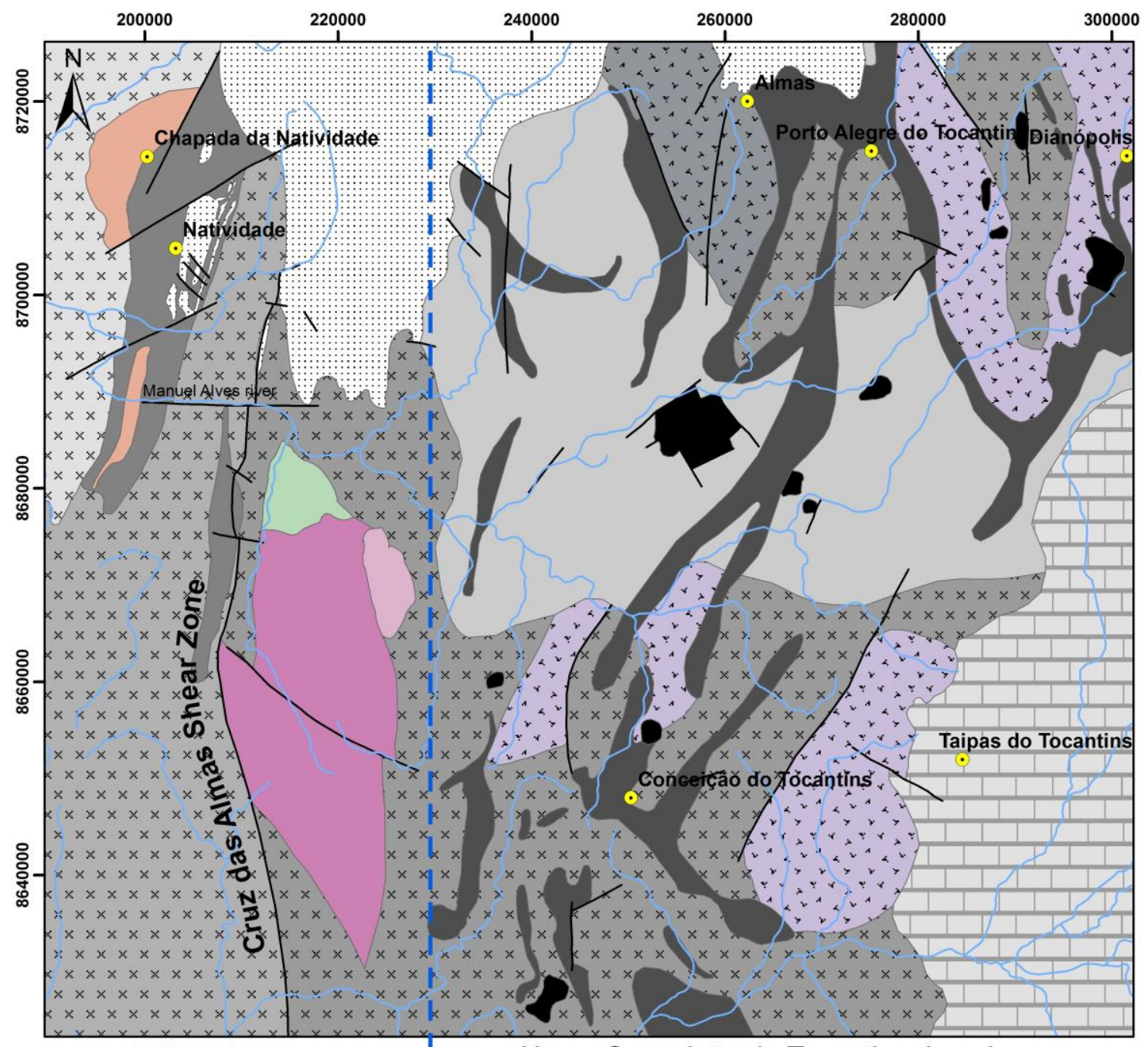

Natividade Basement $\leftarrow, \rightarrow$ Almas-Conceição do Tocantins domain

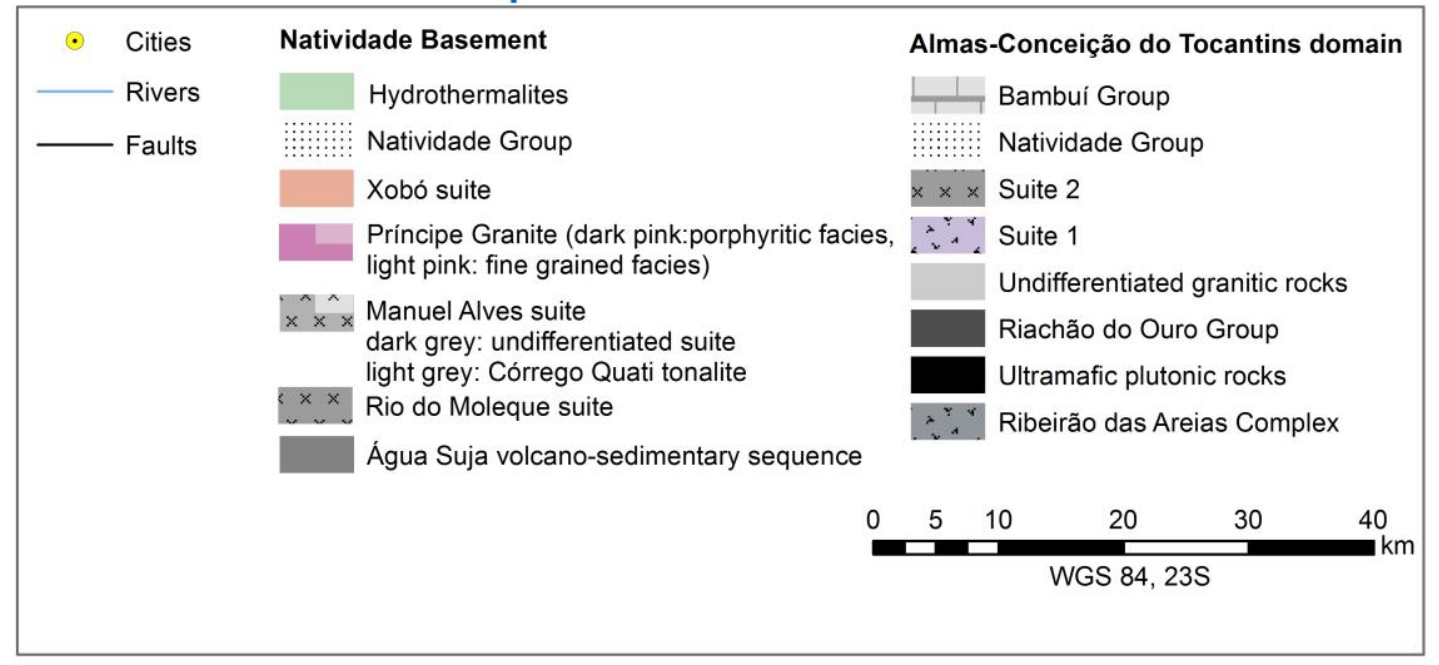

Figure 4.4: Geologic map of Natividade basement and Almas Conceição do Tocantins domain (Modified from Costa et al., 1976; Cruz, 1993 and Oliveira, 2012). Suite 1 and Suite 2 were defined by Cruz (1993). Suite 2 on the wastern limit of Almas-Conceição do Tocantins mapped by Cruz (1993) coincides with Rio do Moleque suite mapped by Oliveira., 2012. 


\subsubsection{Rio do Moleque suite (RM)}

Rio do Moleque suite encompasses tonalites poor in mafic constituents, having biotite as the only mafic mineral. It is the easternmost unit of Natividade basement and was individualized from Manuel Alves suite since there is a fault between the two units, the Cruz das Almas shear zone.

Tonalites from this unit are medium to coarse-grained, have equigranular texture and greyish colour. The rocks are composed of quartz (30-40\%), plagioclase $\mathrm{An}_{10}(30-35 \%)$ and biotite $(10-20 \%)$. K-feldspar is rare (0-5\%), but allanite and epidote are ubiquitous phases as well as muscovite and titanite. The low content of $\mathrm{Ca}$ in plagioclase is interpreted as decalcification of andesine/oligoclase during alteration. Epidote and allanite are believed to be neoformed, but muscovite is a magmatic phase. Some samples show albitization, evidenced by neoformed grains of albite. No pluton is identifiable in RM Suite because of the lack of outcrops.

In QAP diagram of Streckeisen (1976), modal compositions plot in the tonalite field. When highly hydrothermalized, samples have a greenish colour and its paragenesis reequilibrated to quartz-sericite-epidote-titanite, where plagioclase is saussuritized. An area of altered tonalites is mapped as hydrothermalites in Figure 4.4. Rocks from RM suite are generally massive, but in one outcrop magmatic bedding is visible.

\subsubsection{Manuel Alves suite (MA)}

Manuel Alves suite is very similar to RM, but was individualized because the Cruz das Almas Shear Zone is a notable discontinuity between them. MA tonalites are more deformed and crop out in a large strike slip corridor. Samples from this suite are leucocratic, with biotite as the only mafic constituent.

When affected by shear zones, rocks from this unit have a penetrative foliation defined by oriented biotite lamellae. Quartz (30-40\%), plagioclase from $\mathrm{An}_{8}$ to $\mathrm{An}_{12}(30-40 \%)$ and biotite $(15-25 \%)$ are the main minerals, K-feldspar is minimum (0-10\%). Neoformation of epidote is common. Apatite is a usual accessory mineral. As in RM, in MA plagioclase grains are highly saussuritized. In two samples, garnet occurs in relatively large anhedral grains, but is absent in other samples. Euhedral biotite lamellae have a reddish brown colour, plagioclase grains are anhedral and quartz is recrystallized.

Rocks from this unit plot in the tonalite and granodiorite fields of QAP diagram (Streckeisen, 1976). It is not possible to identify and map plutons in MA. 


\subsubsection{Córrego Quati Tonalite (CQ)}

Córrego Quati tonalite is part of the MA, but its homogeneous character and spatial continuity allow us to individualize it. Macroscopically, CQ is almost white and biotite is the only mafic mineral. CQ is composed of quartz (30-40\%), plagioclase $\mathrm{An}_{10-20}(25 \%)$, Kfeldspar (10\%) and biotite (15-25\%). Rocks are plotted in tonalite and granodiorite domains of QAP diagram (Streckeisen, 1976). Quartz has undulose extinction, is recrystallyzed, plagioclase grains are not highly saussiritized but are relatively decalcified. Decalcification is observed by neoformation of epidote and zoisite, and by low anorthite content in plagioclase grains. Magmatic epidote and allanite are also common secondary phases. Euhedral garnet is present in a few samples. Apatite and titanite are accessory minerals. Biotite grains from CQ are euhedral reddish brown lamellae and in some samples biotite is highly chloritized.

\subsubsection{Xobó Suite (XS) and Príncipe Granite (PG)}

Xobó suite crops out in the north-western part of the area, while the Príncipe Granite is an intrusive body in the southeast. In contrast with previous described units, both have granitic composition. They tend to be porphyrytic, are composed of quartz (20-25\%), plagioclase An10 (25-30\%), K-Feldspar (20-25\%), biotite (20\%), garnet and muscovite (sum $15 \%$ ). Príncipe Granite plagioclase grains are saussuritized, quartz is recrystallized, Kfeldspar is microcline and biotite has a brown colour. Allanite and epidote are common secondary phases in Príncipe Granite. Xobó suite constitutes large pegmatitic bodies that hamper sampling. Plagioclase grains from Xobó suite are more preserved, but quartz grains are also recrystallized. In QAP diagram, both XS and PG belong to monzogranite field (Streckeisen,1976).

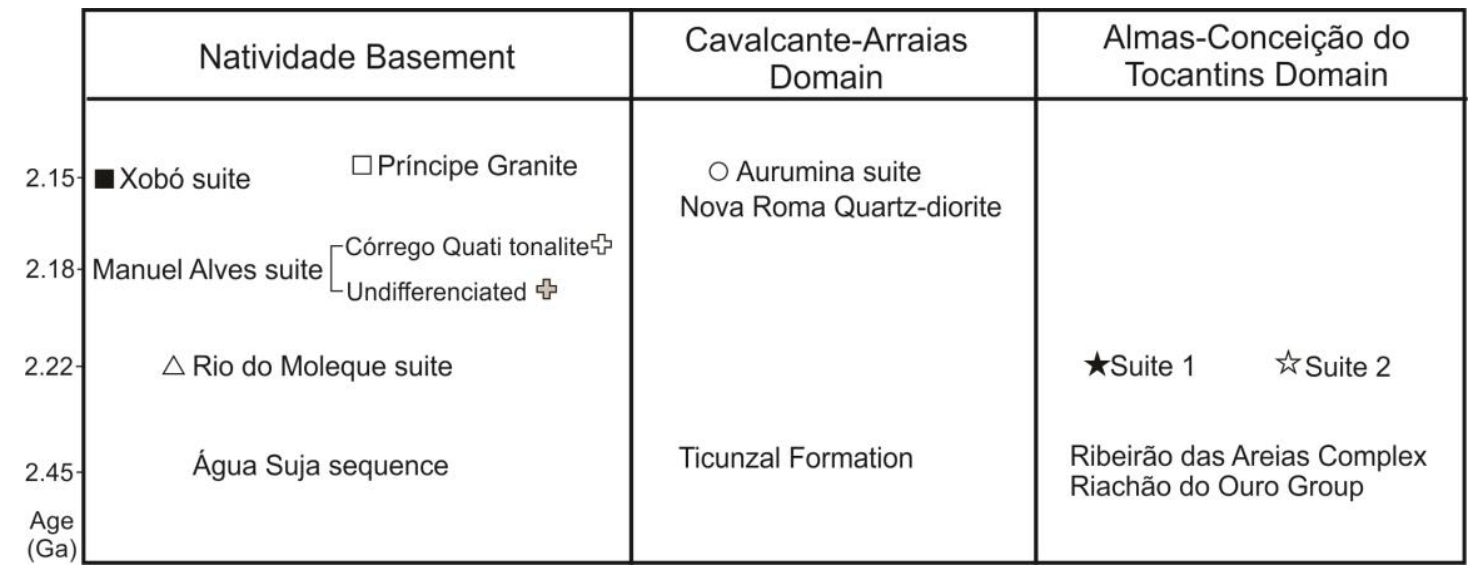

Figure 4.5: Main geologic units in Brasília Belt’s basement. 


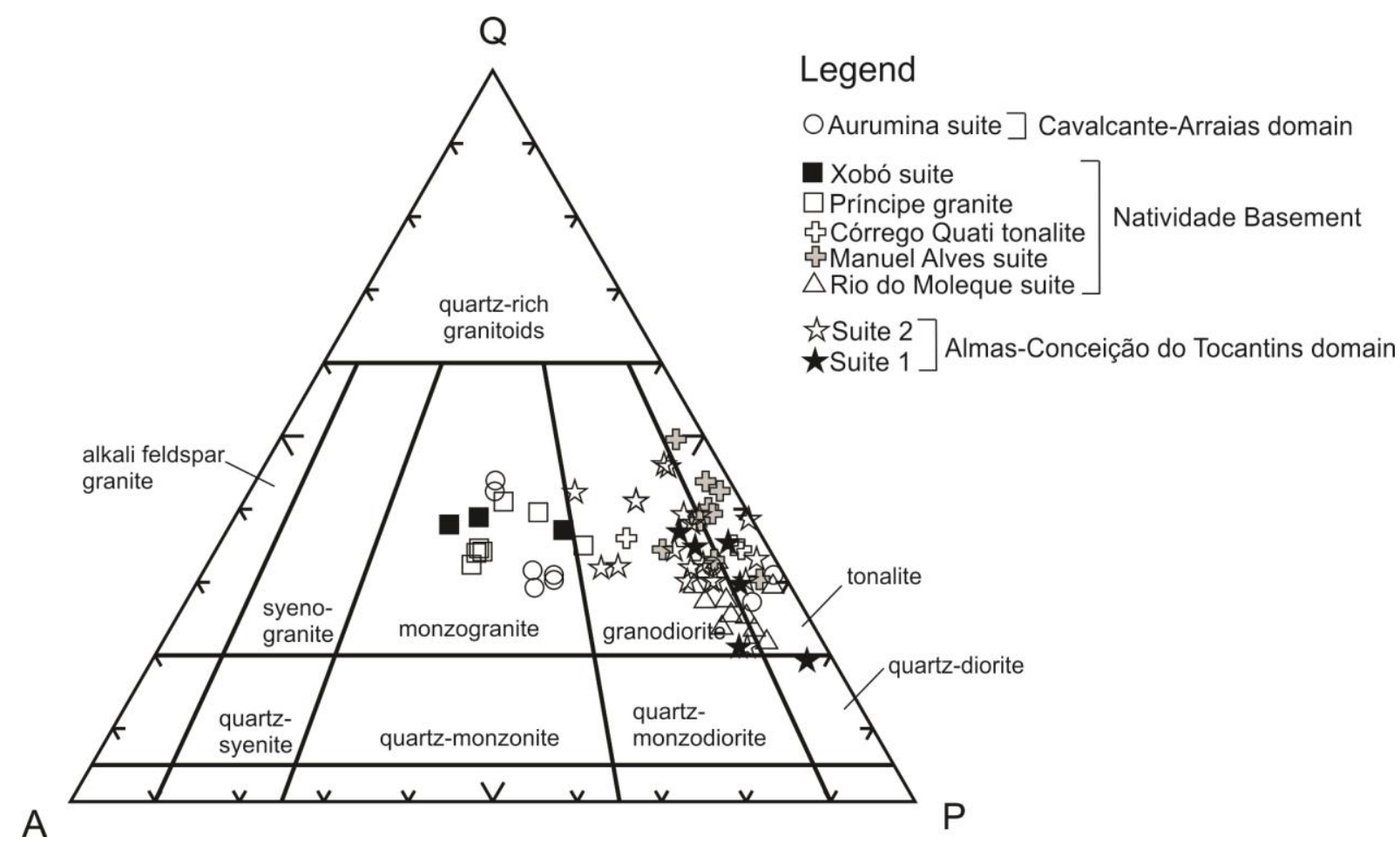

Figure 4.6: QAP diagram (Streckeisen, 1976) Plotted samples are from Natividade basement, Almas Conceição do Tocantins and Cavalcante-Arraias domains.

\subsubsection{Deformation and metamorphism}

These rocks underwent at least two deformational events, the former during Paleoproterozoic and the latter during Brasiliano-Pan Africano orogeny. Nonetheless, in most outcrops only one foliation is observed. That is interpreted as an overprint of Brasiliano on Paleoproterozoic structures. It is possible that both events had similar directions of compression and Paleoproterozoic structures were reactivated by Brasiliano event, being verticalized close to shear zones.

In general, foliation strikes NNE-SSW and dip from $40^{\circ}$ to $90^{\circ}$. Vertical structures show dextral kinematic. In CQ, few outcrops have a south dipping foliation, with s foliation plane indicating transport toward north. It is not representative of the main structural framework, but may indicate convergence direction other than classic E-W from Brasiliano and Paleoproterozoic orogenies.

The Paleoproterozoic event is believed to have achieved amphibolite facies, not clearly noticed in granitic rocks, but evident in basic rocks from volcano-sedimentary sequences (Cruz, 1993). Metamorphic paragenesis of basic rocks from Água Suja sequence and Riachão do Ouro Group include hornblende (Oliveira, 2012; Cruz, 1993) and gondite is described in Água Suja sequence (Oliveira, 2012). 
Brasiliano event reequilibrated paragenesis to greenschist facies and had an important impact on reactivating structures in the basement. Authors suggest gold mineralizations in the region are contemporary to Brasiliano (Queiroz, 2001; Corrêa, 2014, Kuyumjian \& Araújo Filho., 2005).

\subsection{Geophysics}

The whole discussion about this area began by observing analytic signal amplitude of magnetic data and gamma spectrometry image of the area. In both products, there is a clear distinction in geophysical response of Almas-Conceição do Tocantins domain and Natividade basement (Figure 4.7 and Figure 4.8).

Geophysical signature of Almas-Conceição do Tocantins domain shows an area of high frequency signals, probably reflecting high magnetic units from greenstone belt amongst low magnetic TTG domes. Kuyumjian \& Araújo Filho(2005) states greenstone belts form honeycomb shaped stripes, with plutonic bodies in the center. Further west, approximately where Natividade basement begins, it is possible to identify a rupture in this pattern, where high frequency disorderly signals give way to NNE-SSW structures, as entering a low magnetic stike-slip corridor.

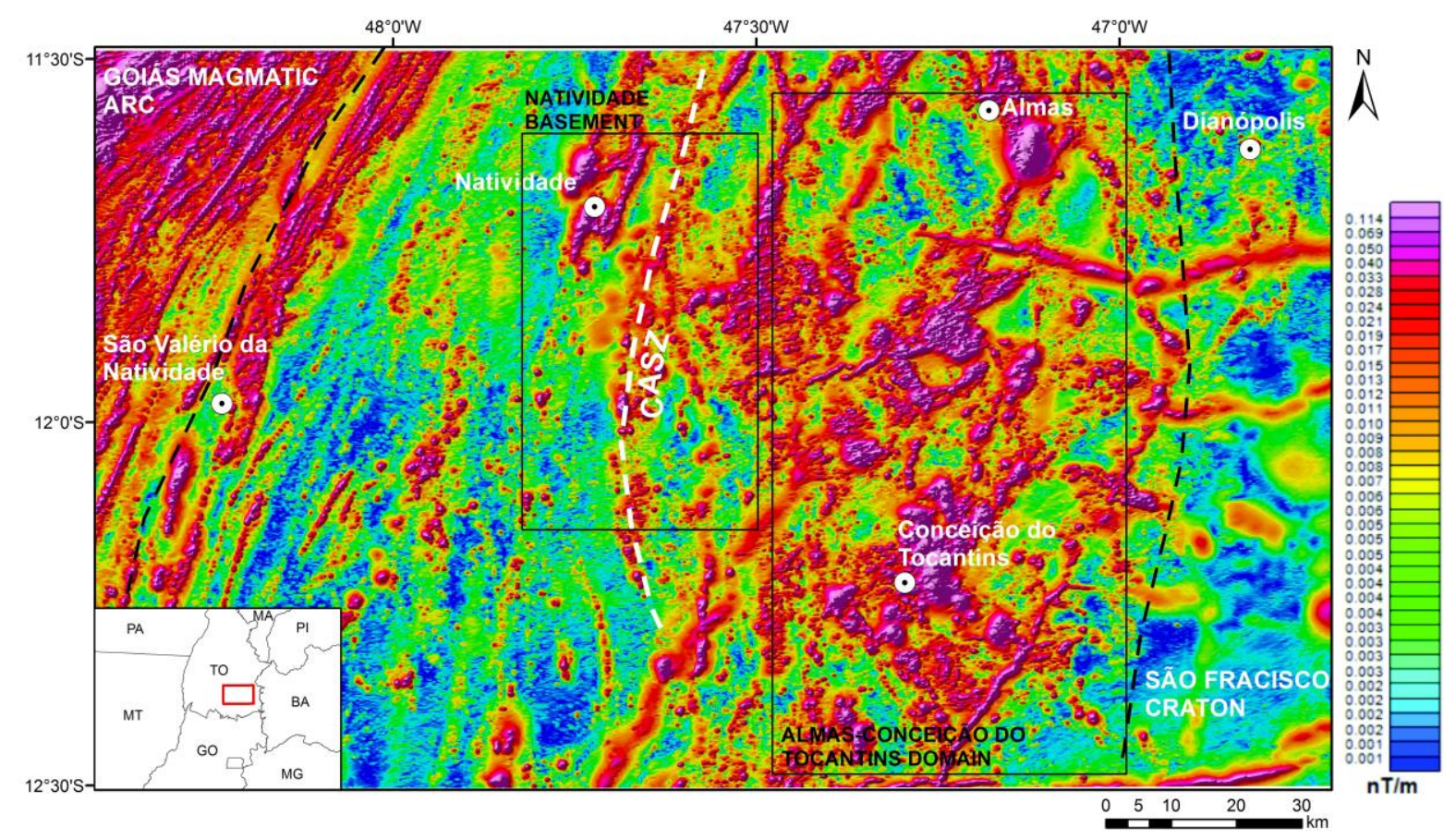

Figure 4.7: ASA image (CPRM, 2006). CASZ: Cruz das Almas Shear Zone. Rectangles delimit Natividade Basement and Almas-Conceição do Tocantins domains. 
This is also noticed in RGB gammaspectomety image. The geophysical limitseems to coincide with Cruz das Almas Shear Zone (Figure 4.7). Geochronological and geochemical analyses east and west of the fault will answer if it is a suture zone or a mere strike-slip fault.

In extreme northwest of the images, Goiás Magmatic Arc displays high structured signals, parallel to the Transbrasiliano Lineament - the western limit of the arc developed during Neoproterozoic.

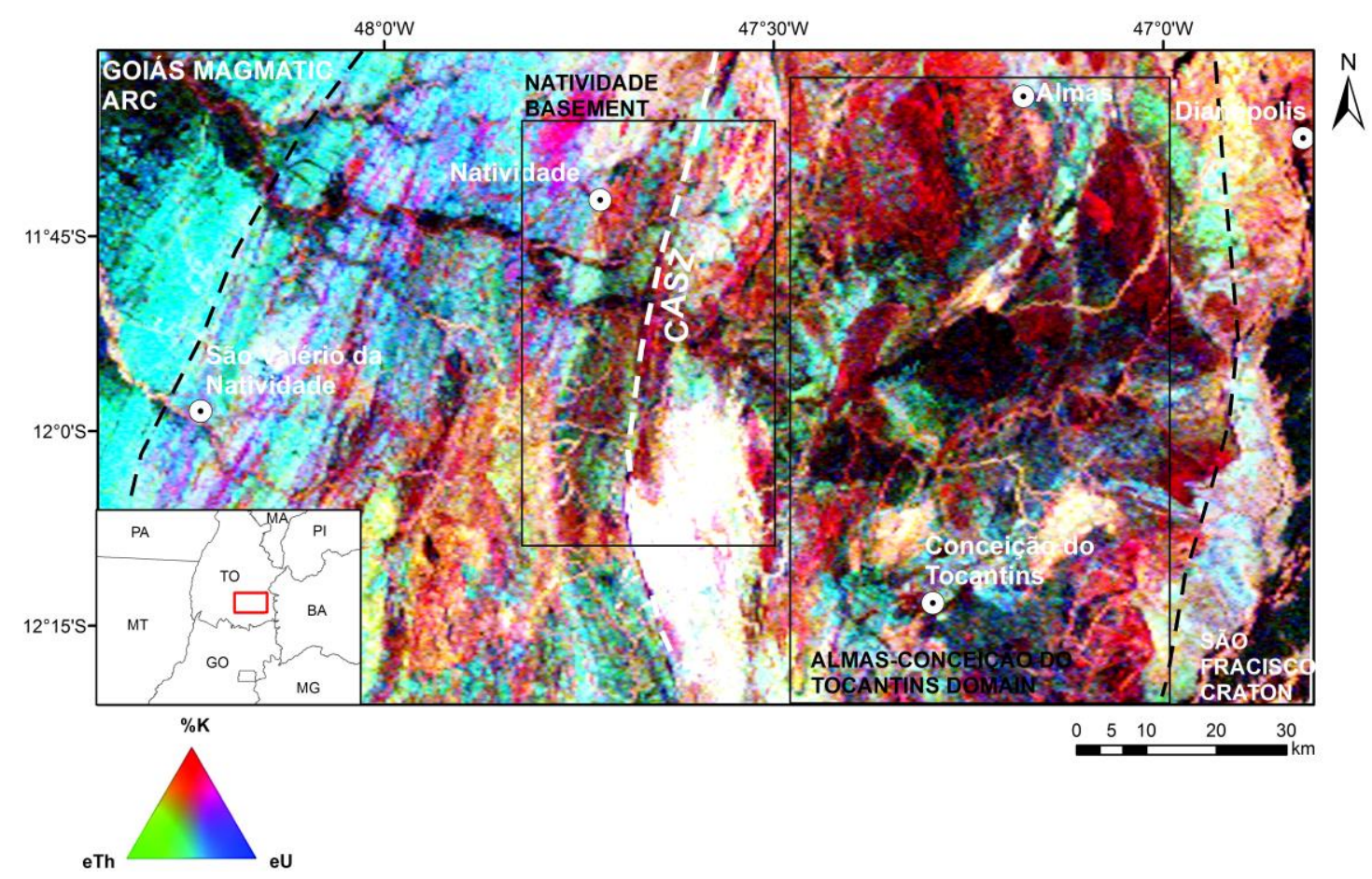

Figure 4.8: False colour composition. Gammaspectometry image (CPRM, 2006). CASZ:Cruz das Almas Shear Zone. Rectangles delimit Natividade Basement and Almas-Conceição do Tocantins domains.

\subsection{Analytical Procedures}

\subsubsection{U-Pb Geochronology}

LA-ICP-MS analyses were performed in the Geochronology Laboratory of the University of Brasília and followed procedures described by Bühn et al. (2009). Rock samples were grinded using SELFRAG High Voltage Pulse Power Fragmentation and then had their dense fraction mechanically separated. Frantz magnetic separator divided dense components into a magnetic and a non-magnetic portion. The non-magnetic portion was examined under a binocular microscope, where zircon grains were handpicked and mounted 
in epofix blocks. Mounts were polished and imaged by electron microscope prior to analysis. In the possession of backscattered electron or cathodoluminescence images, mounts were cleaned with acetone and introduced in New-Wave UP213 Nd:YAG laser $(\lambda=213 \mathrm{~nm})$, the laser ablation equipment attached to multi-collector ICP-MS Thermo Finnigan Neptune. 30 $\mu \mathrm{m}$ laser beam operated with $10 \mathrm{~Hz}$ frequence and 78 to $80 \%$ energy. GJ-1 was the zircon standard used (Jackson et al., 2004). Data reduction and age calculation was possible with ISOPLOT 4.15 (Ludwig, 2008). ${ }^{238} \mathrm{U},{ }^{232} \mathrm{Th},{ }^{206} \mathrm{~Pb}$ and ${ }^{208} \mathrm{~Pb}$ were measured in Faraday cups, while ${ }^{204} \mathrm{~Pb},{ }^{207} \mathrm{~Pb}$ and ${ }^{202} \mathrm{Hg}$ were collected in ion counters. Errors are expressed at $1 \sigma$ level.

\subsubsection{Sm-Nd isotopic analyses}

Rock samples were powdered in a pan mill and whole rock analyses were carried out in Geochronology Laboratory of the University of Brasília employing TIMS (Thermal Ionization Mass Spectrometry). Analyses followed procedures described by Gioia \& Pimentel (2000). TRITON ${ }^{\mathrm{TM}}$ Plus Multicollector was the equipment used to determine isotope proportions. Results include Sm and Nd concentrations in ppm and ${ }^{147} \mathrm{Sm} /{ }^{144} \mathrm{Nd}$ e ${ }^{143} \mathrm{Nd} /{ }^{144} \mathrm{Nd}$ ratios. Data were processed using ISOPLOT 4.15 (Ludwig, 2008). Errors are expressed at $2 \sigma$ level.

\subsubsection{Geochemistry}

Rocks were powdered in a pan mill, using agate or vidia pans. Whole rock powders were analyzed by ICP-ES for major elements and ICP-MS for trace-elements, including rareearth elements. Analyses were held at Acme Analytical Laboratories Ltd. Chemical diagrams were generated using IgPet software (Carr \& Gazel, 2006).

\subsection{Results}

\subsubsection{U-Pb}

All dated samples evince zircon $\mathrm{Pb}$ loss and ages defined by discordia upper intercepts. Lower intercepts have a high associated error, but when indicating ages between 500 and 800 Ma may reflect the Brasiliano resetting of U-Pb system.

$\mathrm{RM}$ rocks, west from Cruz das Almas Shear Zone, are the oldest units in the area. Two dated samples from easternmost Natividade basement yield ages of $2231 \pm 14 \mathrm{Ma}$ and

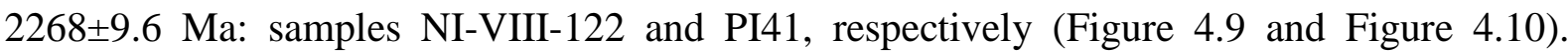
Sample G3 is from the highly altered zone north from Príncipe Granite, crops out within RM, and indicates $2446 \pm 68 \mathrm{Ma}$. 
West from Cruz das Almas Shear Zone, MA sample discordia intercepts at $2185 \pm 6.5$

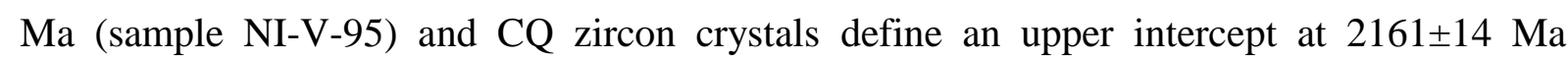
(sample G7), Figure 4.11.

Within CQ, a sample from a small hill yield age of $2201 \pm 7$ (Sample NI-V-24B). It is possible that the whole hill is a xenolith, once it is the only topographic high within the granitic basement and CQ is younger, as seen in sample G7. CQ is probably intrusive in slightly older tonalites.

In general terms, according to spatial distribution of analysed samples, it seems eastern samples are slightly older than western units, although differences in age are discrete.

Xobó suite and both facies from Príncipe Granite present the youngest ages found. Príncipe Granite sample dated is a typical biotite granite, and has two distinct alignments of grains presenting upper intercepts at $2127 \pm 45 \mathrm{Ma}$ and at $2328 \pm 34 \mathrm{Ma}$ (Figure 4.12). The younger intercept is interpreted as crystallization age while the older intercept is formed by alignment of inherited zircon grains.

Fine grained Príncipe Granite facies yield an age of $2144 \pm 37$ and has no evidence of zircon grain inheritance. Xobó suite sample is a leucocratic fine grained granite, poor in biotite, but rich in muscovite. Analysis indicates $2152 \pm 18$ Ma for igneous crystallization.

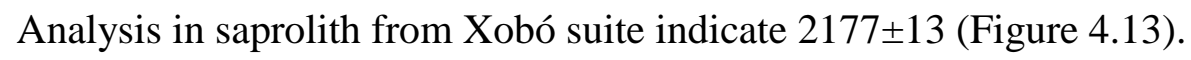

Figure 4.14 shows on the map, where dated samples were collected.
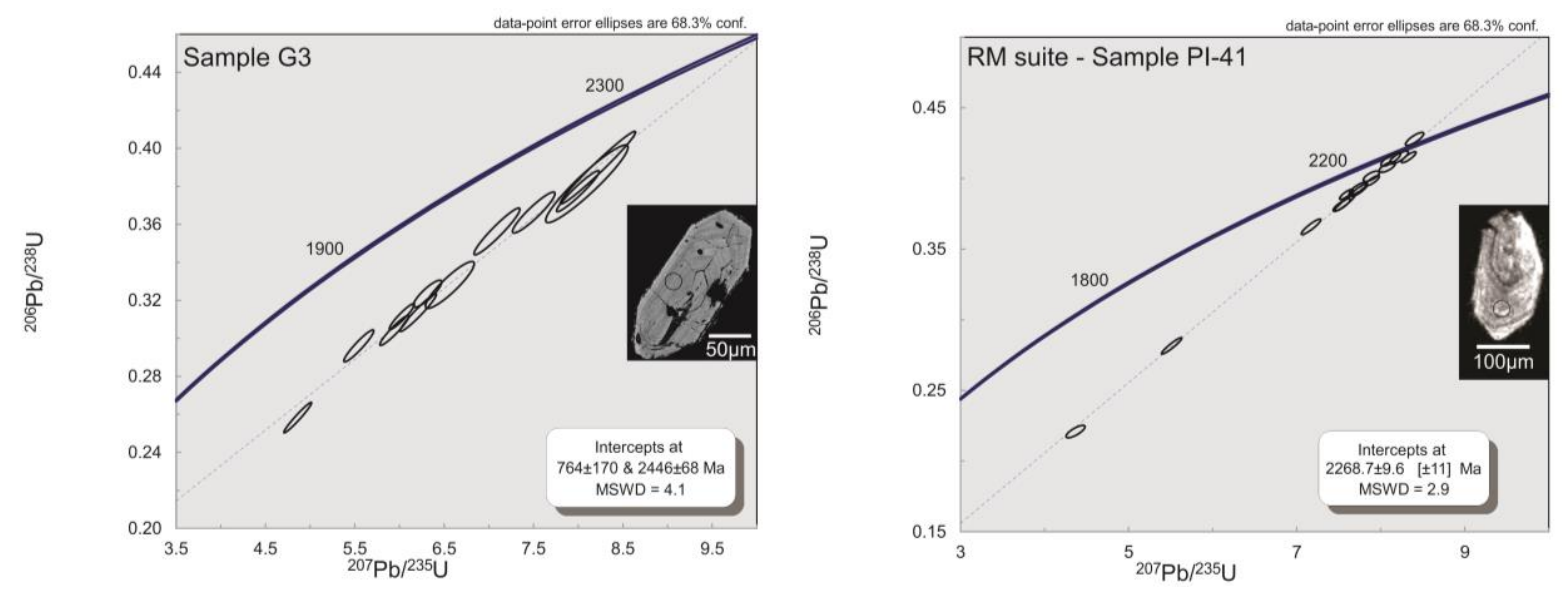

Figure 4.9: Sample G3 is the oldest rock found in Natividade basement. It crops out within RM suite, but is probably its basement or a xenolith. Sample PI41 represents the true age of RM suite. 

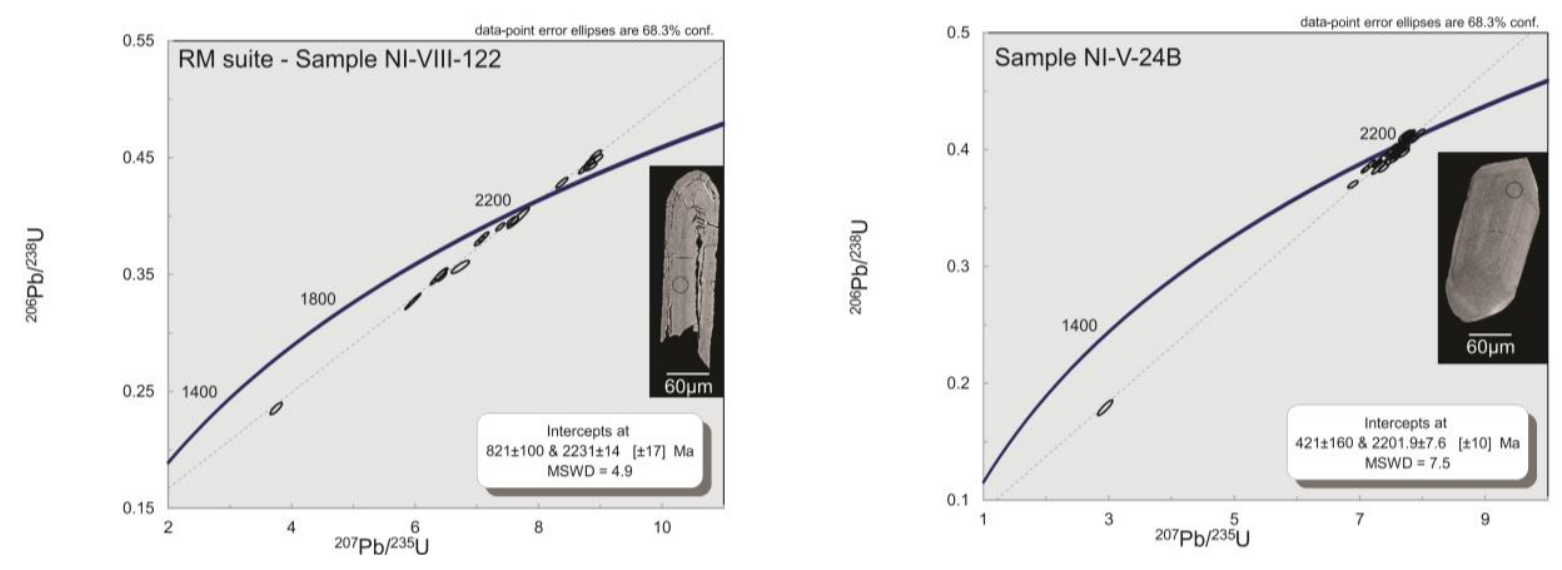

Figure 4.10: Sample NI-VIII-122 is similar to PI41, both from RM suite. NI-V-24 tcropsou within CQ tonalite, but it is older than it. CQ tonalite is probably intrusive in rocks of RM age.
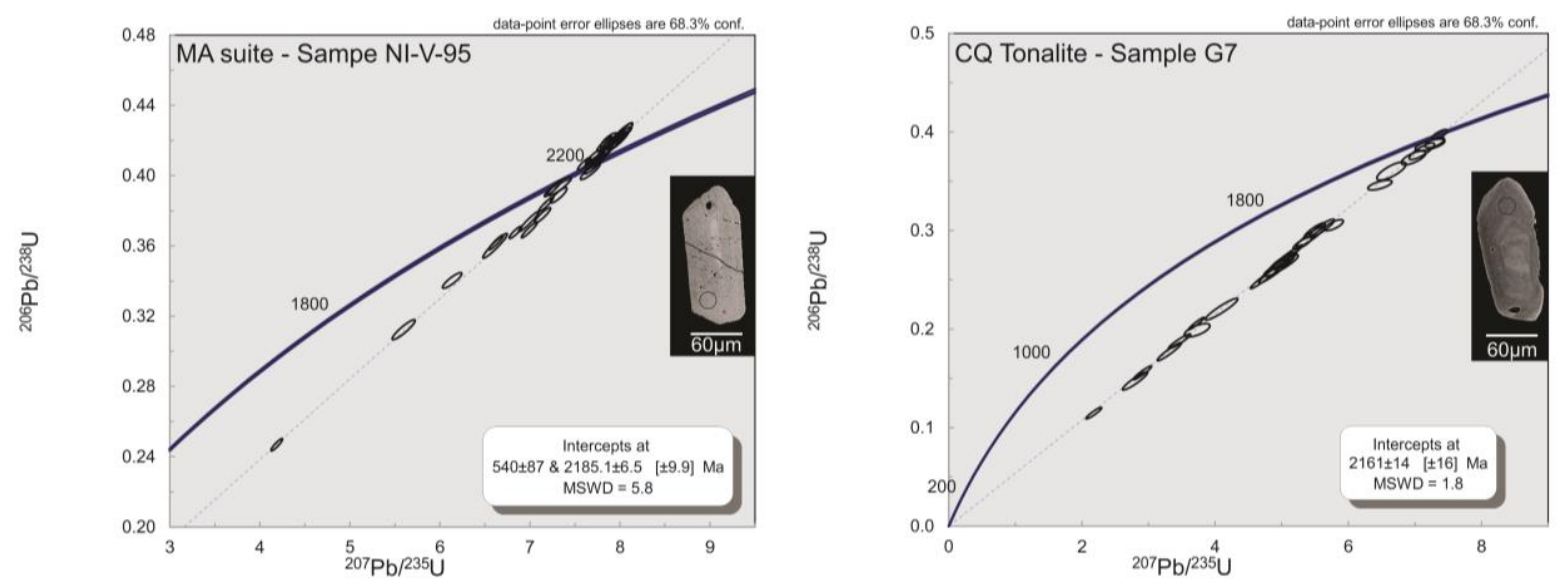

Figure 4.11: Sample NI-V-95 is from MA suite. Sample G7 is from CQ tonalite.
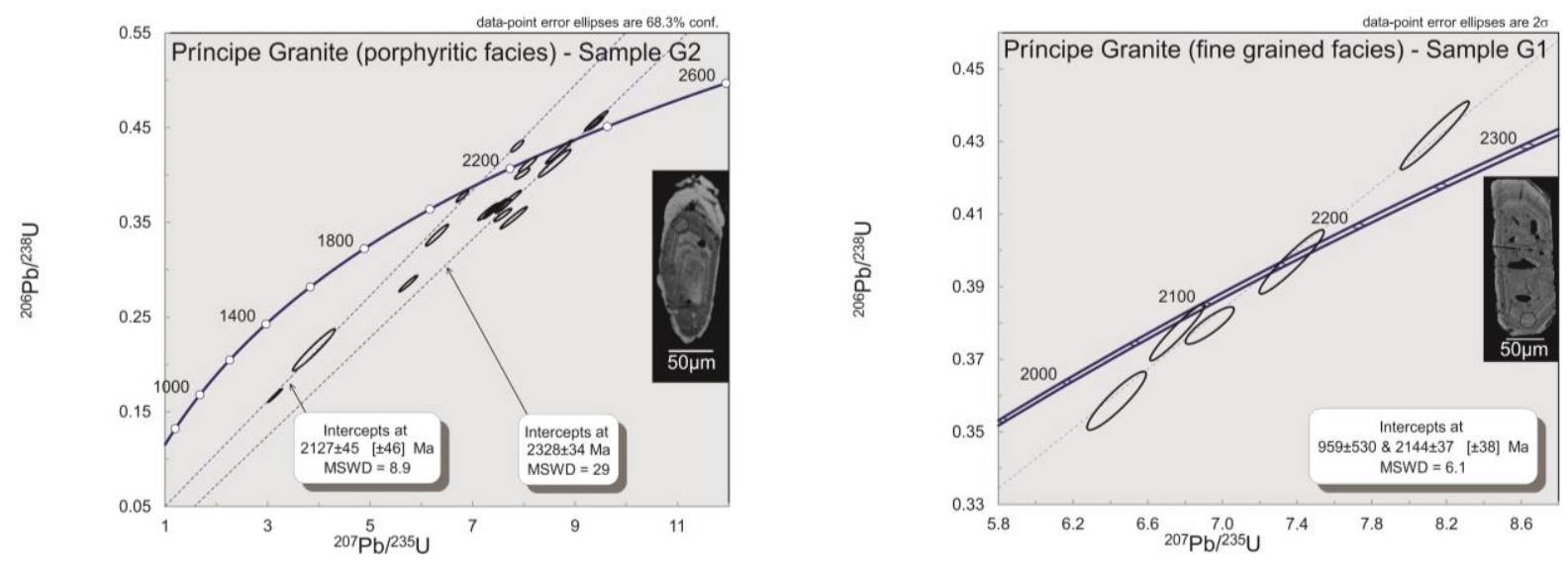

Figure 4.12: Discordia ages for both porphyritic and fine-grained facies from Príncipe Granite. 

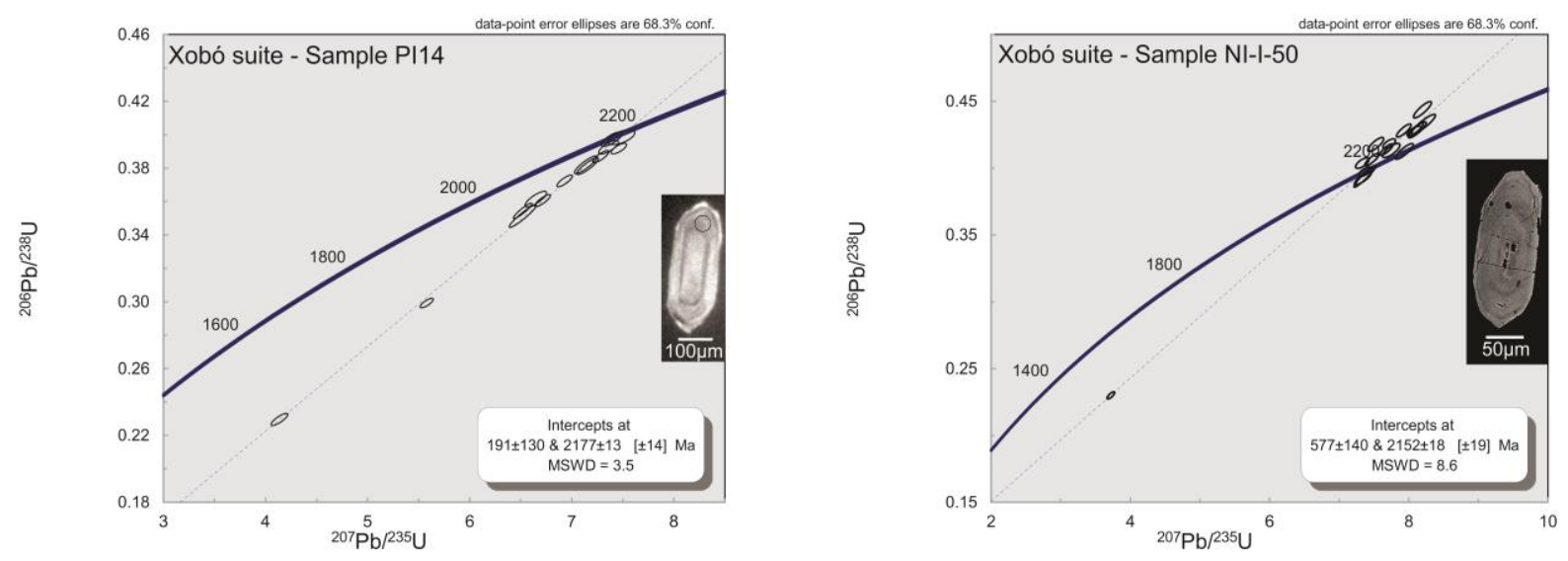

Figure 4.13: Discordia ages in Xobó suite. 


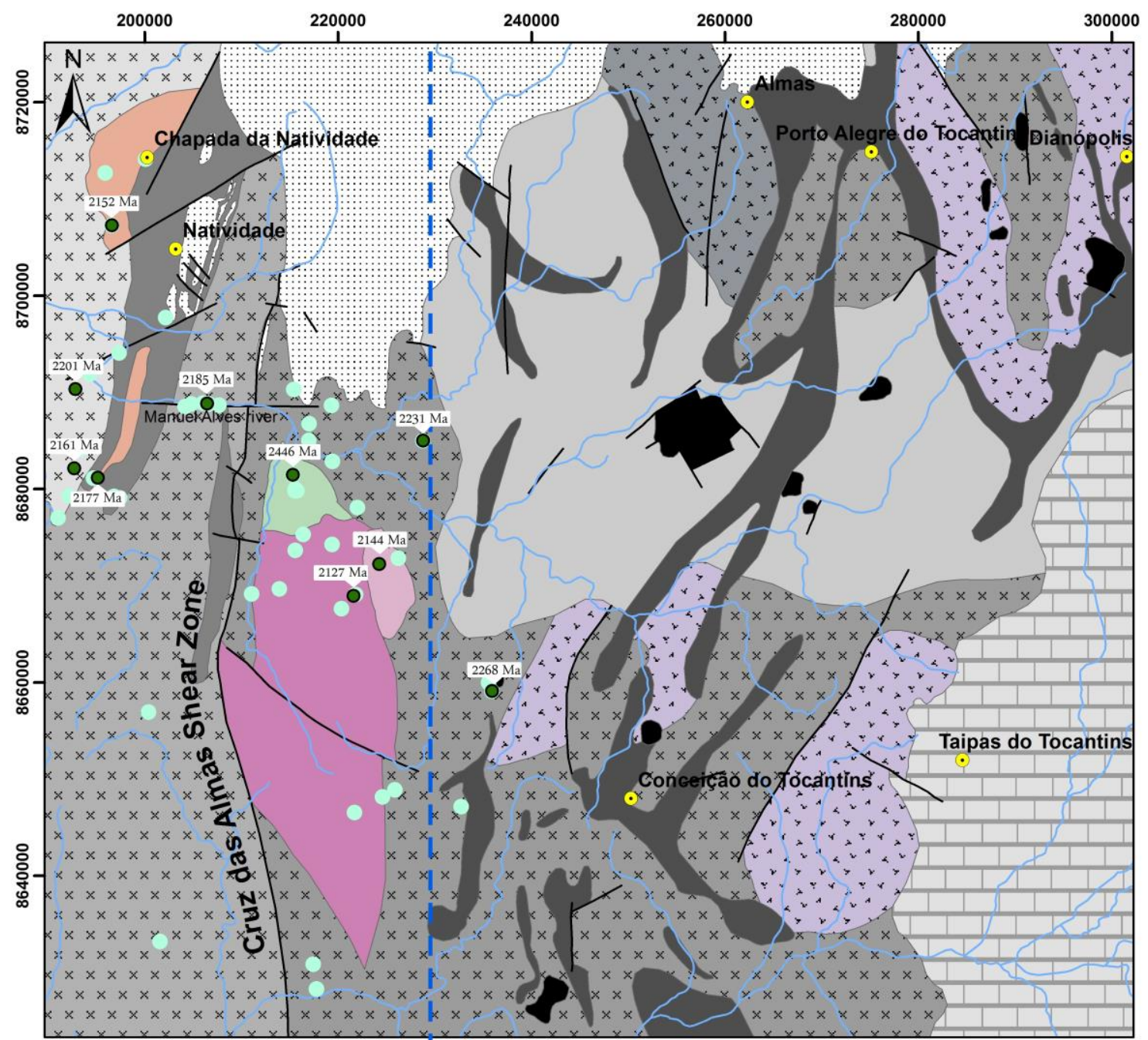

Natividade Basement $\leftarrow, \rightarrow$ Almas-Conceição do Tocantins domain

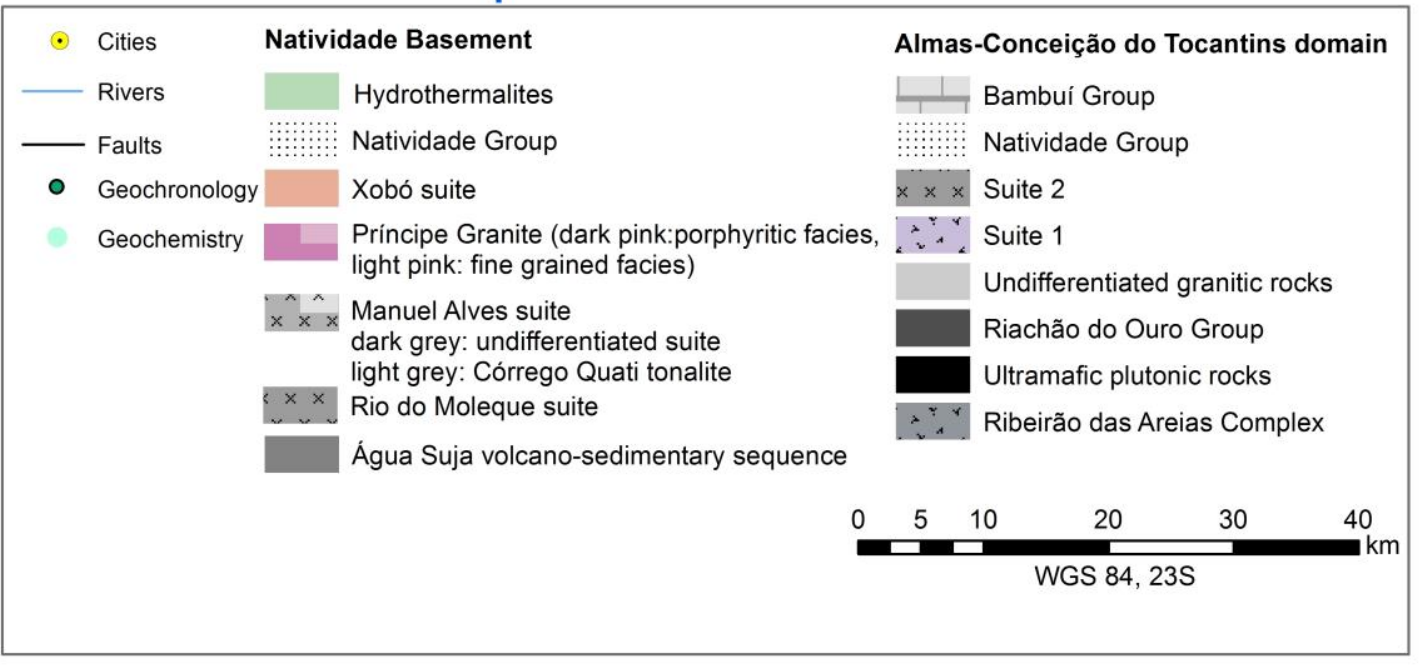

Figure 4.14:. Natividade basement and Almas Conceição do Tocantins domain showing distribution of new geochronological and geochemical data (Modified from Costa et al., 1976; Cruz, 1993 and Oliveira, 2012). 


\subsubsection{Geochemistry}

Major and trace-element chemical composition of the five granitic units are presented compared in Table 4.1. Litogeochemistry from Aurumina suite (Botelho et al., 2002; 2006), from Suite 1 and Suite 2 (Cruz, 1993) are also presented in tables and diagrams for comparison.

Almost every analysed rock sample shows some degree of weathering, as they crop out in a tropical region and underwent at least two deformational events in the past $2 \mathrm{Ga}$. Major elements must be carefully interpreted. Samples with loss on ignition greater than $2 \%$ are excluded from major element diagrams.

\section{- Almas-Conceição do Tocantins Domain}

Data from Suite 1 (S1) are available in Cruz (1993). $\mathrm{SiO}_{2}$ concentration ranges from 54.36 to $73.98 \%$. Samples from this unit have the highest contents of $\mathrm{Fe}_{2} \mathrm{O}_{3}+\mathrm{MnO}+\mathrm{MgO}+\mathrm{TiO}_{2}(0.8-14 \%)$ and the lower alumina saturation index $(0.5-1.1)$, revealing its metaluminous character.

Suite 2 (S2) tonalites and granodiorites' results are also from Cruz (1993). $\mathrm{SiO}_{2}$ ranges from 59.80 to $73.81 \%$. This suite presents lower concentrations of $\mathrm{Fe}_{2} \mathrm{O}_{3}+\mathrm{MnO}+\mathrm{MgO}+\mathrm{TiO}_{2}$ than $\mathrm{S} 1$. In contrast to $\mathrm{S} 1, \mathrm{~S} 2$ has ASI from 0.8 to 1.3 and exhibits slightly peraluminous granitoids.

\section{- Natividade Basement}

RM suite tonalites are similar to $\mathrm{S} 2$ in mineralogy and are also weakly peraluminous (ASI from 0.97 to 1.1). $\mathrm{SiO}_{2}$ varies from 63.12 to $73.69 \%$.

MA suite shows a wide range of chemical composition $\left(\mathrm{SiO}_{2}\right.$ varies from 66.19 to 76.19\%). Rocks from this suite are all peraluminous (ASI = 1.0 to 1.4) and are similar to S 2 .

Príncipe Granite and Xobó suite are the two granitic units studied that clearly represent more evolved melts, confirmed by their high content in $\mathrm{SiO}_{2}$ (73-74\%), low $\mathrm{CaO}$ percentage and low $\mathrm{Fe}_{2} \mathrm{O}_{3}+\mathrm{MnO}+\mathrm{MgO}+\mathrm{TiO}_{2}$. All samples from these units are peraluminous (ASI=1.04 to 1.27 ).

- Arraias-Cavalcante domain

Aurumina suite $(\mathrm{Au})$ is divided in four facies, all peraluminous. Muscovite granites compose Au1, Au2 has biotite-muscovite granites, Au3 has tonalites and Au4, biotite 
granites. Litochemistry from facies Au1, Au2 and Au3 are in Botelho et al. (2002, 2006); no analysis of $\mathrm{Au} 4$ is available.

Facies Au1 and Au2 are chemically similar, but facies Au3 is significantly different. Facies $\mathrm{Au} 1$ and $\mathrm{Au} 2$ have higher contents of $\mathrm{SiO}_{2}$ and $\mathrm{K}_{2} \mathrm{O}$, and higher ASI than facies Au3. 
Table 4.1: Comparison of units within the basement.

\begin{tabular}{|c|c|c|c|c|c|c|c|c|c|c|}
\hline & \multicolumn{2}{|c|}{$\begin{array}{l}\text { Almas-Conceição do } \\
\text { Tocantins Domain }\end{array}$} & \multicolumn{5}{|c|}{ Natividade Basement } & \multirow{2}{*}{\multicolumn{3}{|c|}{$\begin{array}{r}\text { Cavalcante - Arraias Domain } \\
\text { Aurumina suite } \\
\end{array}$}} \\
\hline & \multirow{2}{*}{ Suite $1^{\mathrm{a}}$} & \multirow{2}{*}{ Suite $2^{\mathrm{a}}$} & \multirow{2}{*}{ RM suite } & \multicolumn{2}{|c|}{ MA suite } & \multirow{2}{*}{ Xobó Suite } & \multirow{2}{*}{$\begin{array}{l}\text { Príncipe } \\
\text { Granite }\end{array}$} & & & \\
\hline & & & & Undifferetiated & Córrego Quati Tonalite & & & $\mathrm{Au} 1$ & $\mathrm{Au} 2$ & $\mathrm{Au} 3$ \\
\hline $\begin{array}{l}\text { Petrographic } \\
\text { types (QAP) }\end{array}$ & $\begin{array}{l}\text { Tonalite, } \\
\text { granodiorite }\end{array}$ & $\begin{array}{l}\text { Tonalite, } \\
\text { granodiorite }\end{array}$ & Tonalite & Tonalite & Tonalite, granodiorite & Bt-ms granite & $\begin{array}{l}\text { Bt-ms } \\
\text { granite }\end{array}$ & Ms granite & Bt-ms granite & Tonalite \\
\hline $\begin{array}{l}\text { Mafic } \\
\text { mineralogy }\end{array}$ & $\begin{array}{l}\text { amphibole and } \\
\text { biotite }\end{array}$ & biotite & biotite & biotite & biotite & biotite & biotite & biotite & biotite & biotite \\
\hline $\begin{array}{l}\text { Accessory } \\
\text { mineralogy }\end{array}$ & apatite, zircon & $\begin{array}{l}\text { apatite, } \\
\text { zircon }\end{array}$ & $\begin{array}{l}\text { zircon, epidote, } \\
\text { titanite, apatite, } \\
\text { allanite }\end{array}$ & apidote, zircon & $\begin{array}{l}\text { epidote, apatite, } \\
\text { titanite, zircon }\end{array}$ & $\begin{array}{l}\text { zircon, } \\
\text { apatite }\end{array}$ & zircon & $\begin{array}{l}\text { zircon, apatite, } \\
\text { ilmenite }\end{array}$ & $\begin{array}{l}\text { apatite, zircon, } \\
\text { thorite, monazite, } \\
\text { ilmenite }\end{array}$ & $\begin{array}{l}\text { apatite, } \\
\text { zircon, } \\
\text { allanite }\end{array}$ \\
\hline $\begin{array}{l}\mathrm{SiO}_{2} \\
\text { (avarage) }\end{array}$ & 62.908 & 69.01 & 67.53 & 71.17 & 71.43 & 74.13 & 73.12 & 72.17 & 70.31 & 67.66 \\
\hline $\mathrm{K}_{2} \mathrm{O} / \mathrm{Na}_{2} \mathrm{O}$ & $0.19-1.21$ & $0.2-1.5$ & $0.33-0.66$ & $0.2-1.3$ & $0.2-0.7$ & 1.07 & $0.86-1.86$ & $1.11-1.35$ & $1.17-1.39$ & $0.20-0.94$ \\
\hline $\begin{array}{l}\text { Alumina } \\
\text { saturation } \\
\text { index }\end{array}$ & $0.5-1.1$ & $0.8-1.3$ & $0.97-1.1$ & $1.0-1.4$ & $1.06-1.07$ & 1.21 & $1.04-1.27$ & $1.14-1.19$ & $1.17-1.39$ & $1.03-1.06$ \\
\hline $\mathrm{K}_{2} \mathrm{O}$ (wt. \%) & $0.96-4.35$ & $1.09-4.35$ & $1.47-2.57$ & $0.94-2.3$ & $1.3-2.9$ & 4.11 & $3.3-5.4$ & $4.5-5.1$ & $4.7-5.2$ & $1.0-3.1$ \\
\hline $\mathrm{Na}_{2} \mathrm{O}$ (wt. \%) & $2.09-5.78$ & $2.2-4.9$ & $3.8-4.9$ & $1.7-4.8$ & $3.8-4.6$ & 3.82 & $2.8-4.1$ & $3.8-4.0$ & $2.3-3.3$ & $3.3-4.9$ \\
\hline $\mathrm{CaO}(\mathrm{wt} \%)$ & $1.16-7.44$ & $1.2-5.47$ & $2.5-4.48$ & $1.2-3.5$ & $2.1-3.3$ & 0.72 & $0.24-1.12$ & $0.93-0.95$ & $0.27-1.54$ & $3.0-4.0$ \\
\hline $\begin{array}{l}\mathrm{Fe}_{2} \mathrm{O}_{3}+\mathrm{MnO} \\
+\mathrm{MgO}+ \\
\mathrm{TiO}_{2}(\mathrm{wt} \%)\end{array}$ & 0.8 a 5 e $10-14$ & $1.84-9.2$ & $3.3-7.9$ & $3.3-7.3$ & $3.3-4.0$ & 0.92 & $1.8-3.5$ & $1.5-2.09$ & $2.4-5.3$ & $2.0-8.3$ \\
\hline $\mathrm{Rb}(\mathrm{ppm})$ & na & na & $33-64$ & $27-110$ & $79-116$ & 222 & $119-400$ & $217-272$ & $280-368$ & $41-152$ \\
\hline $\mathrm{Sr}(\mathrm{ppm})$ & 167- 964 & $50-1132$ & $593-935$ & $147-415$ & $214-321$ & 43 & $55-186$ & $113-132$ & $86-180$ & $267-668$ \\
\hline $\mathrm{Ba}(\mathrm{ppm})$ & $376-2175$ & $372-2896$ & $614-1363$ & $374-913$ & $157-483$ & 185 & $417-902$ & $278-398$ & $481-622$ & $219-860$ \\
\hline $\mathrm{Zr}(\mathrm{ppm})$ & $24-69$ & $18-220$ & $107-257$ & $73-326$ & $83-129$ & 88 & $149-260$ & $59-85$ & $42-262$ & $73-284$ \\
\hline $\mathrm{Y}(\mathrm{ppm})$ & $3-35$ & $3-53$ & $10-21$ & $2-29$ & $7-10$ & 13 & $7-17$ & $6-7$ & $11-17$ & $5-25$ \\
\hline $\mathrm{Nb}(\mathrm{ppm})$ & na & na & $5.1-9.6$ & $3.2-7.6$ & $6.5-8.6$ & 9.5 & $6-14$ & $6-9$ & $7-11$ & $2-15$ \\
\hline
\end{tabular}


4. Evolução crustal riaciana do embasamento paleoproterozóico da Faixa Brasília

\begin{tabular}{|c|c|c|c|c|c|c|c|c|c|c|}
\hline $\mathrm{Ni}(\mathrm{ppm})$ & $1-62$ & $3-64$ & $1-16$ & $2.5-39.6$ & $5.7-7$ & 0.6 & $1.4-3.7$ & na & $2.3-4.8$ & $1.3-33.8$ \\
\hline$\Sigma$ REE (ppm) & $94-233$ & $36-153$ & $113-329$ & $52-598$ & $58-105$ & 81 & $41-410$ & $60-110$ & $238-495$ & $32-131$ \\
\hline $\mathrm{La} / \mathrm{Yb}(\mathrm{n})$ & $9-15$ & $15-88$ & $14-51$ & $6-194$ & $5-15$ & 14.05 & $1-77$ & $30-55$ & $37-184$ & $6-18$ \\
\hline $\mathrm{Eu} / \mathrm{Eu}^{*}$ & $0.5-1$ & $0.82-1.2$ & $0.80-0.94$ & $0.37-1.69$ & $0.57-0.91$ & 0.16 & $0.2-0.5$ & na & 0.2 & $0.88-0.89$ \\
\hline $\mathrm{Ba} / \mathrm{La}$ & $20-76$ & $34-44$ & $9-29$ & $6-36$ & $13-24$ & 10 & $5-164$ & $16-20$ & $4-9$ & $11-32$ \\
\hline $\mathrm{Sr} / \mathrm{Y}$ & $14-64$ & $96-151$ & $7-74$ & $8-197$ & $24-43$ & 3 & $3-39$ & $18-19$ & $6-10$ & $10-126$ \\
\hline $\mathrm{Rb} / \mathrm{Sr}$ & na & na & $0.04-0.19$ & $0.05-0.6$ & $0.29-0.54$ & 5 & $0.77-7.19$ & $1.6-2.3$ & $1.5-4.2$ & $0.1-0.4$ \\
\hline $\mathrm{Nb} / \mathrm{Ta}$ & na & na & $6-27$ & $6-16$ & $5-8.6$ & 6 & $6-14$ & $1.9-3.1$ & $8.3-9.8$ & $5.2-10.7$ \\
\hline Age (Ma) & $2.2^{\mathrm{c}}$ & $2.2^{\mathrm{c}}$ & $2.22-2.26$ & 2.18 & 2.16 & 2.15 & $2.12-2.14$ & \multicolumn{3}{|c|}{$2.12-2.17$} \\
\hline$T_{\mathrm{DM}}(\mathrm{Ga})$ & $2.44-2.53^{\mathrm{c}}$ & $2.520-2.72^{c}$ & $2.39-2.58$ & $2.25-3.11$ & $2.37-2.50$ & 2.81 & $2.34-2.83$ & \multicolumn{3}{|c|}{$2.4-2.6$} \\
\hline$\varepsilon N d(t)$ & -1.37 to -0.15 & -4.95 to -0.88 & -1.99 to 0.2 & -3.2 to 2.04 & -0.23 to 0.46 & -2.04 & -5.13 to -0.26 & \multicolumn{3}{|c|}{-3 to -1} \\
\hline
\end{tabular}

${ }^{a}$ Data from Cruz (1993).

${ }^{\mathrm{b}}$ Data from Botelho et al. (2006).

${ }^{\mathrm{c}}$ Data from Cruz (2001).

*Europium anomaly: (Eu/0.0735)/sqrt[(Sm/0.194)*(Gd/0.259)]. Chondrite-normalized values (Taylor \& McLennan, 1984). 
Similar to modal classification, in $\mathrm{SiO}_{2}$ vs. $\mathrm{Na}_{2} \mathrm{O}+\mathrm{K}_{2} \mathrm{O}$ diagram (Le Bas et al., 1986), samples from MA, RM and CQ plot in the transition between granodiorite and granite, while Príncipe Granite and Xobó suite are frankly granites (Figure 4.15). Aurumina suite samples belong in granite field, S2 blends with MA, RM and CQ, but S1 has a less evolved character, being the poorest in $\mathrm{SiO}_{2}$.

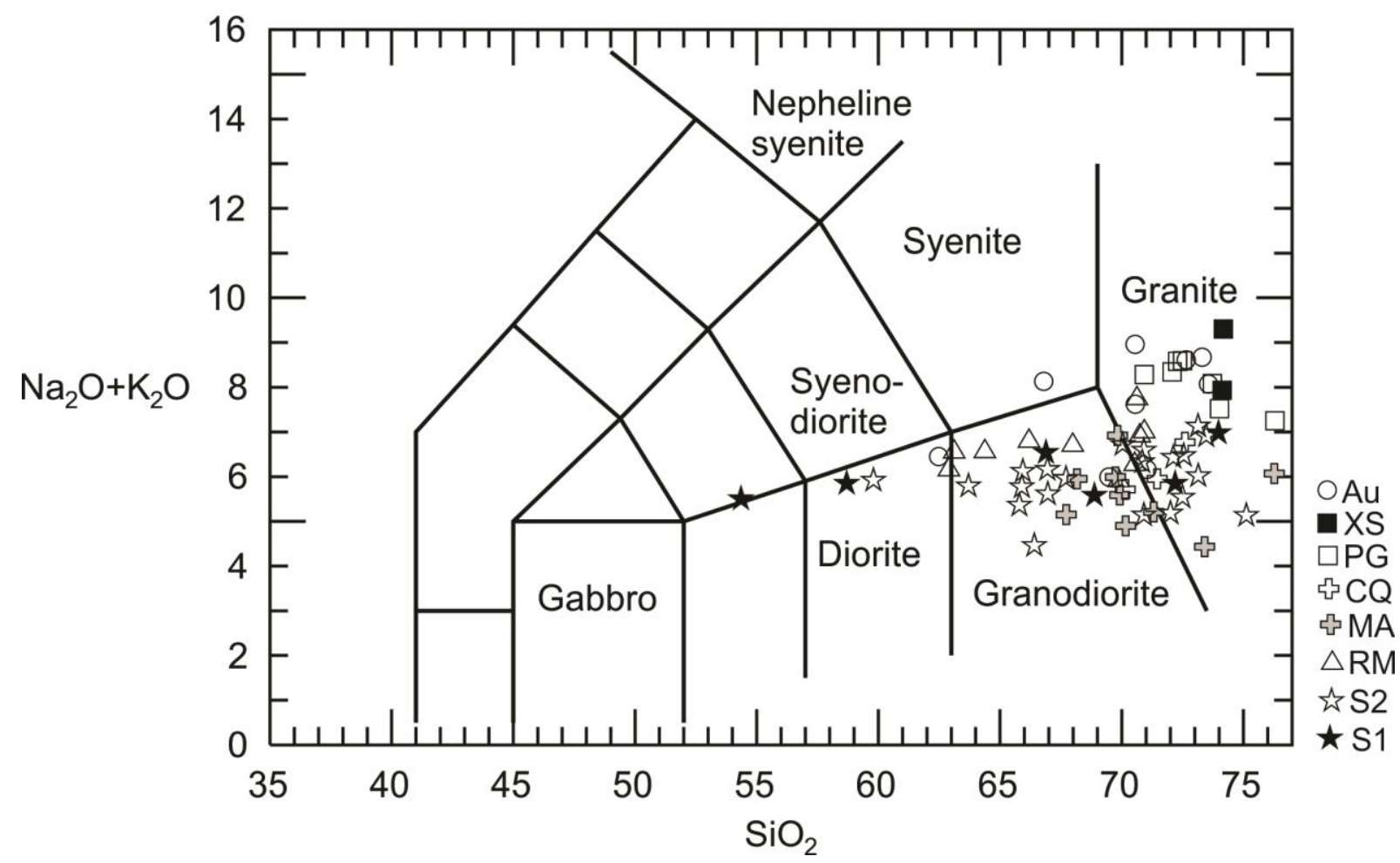

Figure 4.15: Total Alkali-Silica diagram (Le Bas et al., 1986).

$\mathrm{SiO}_{2}$ vs $\mathrm{K}_{2} \mathrm{O}$ diagram (Peccerillo and Taylor, 1976) reveals the calc-alkaline character of Natividade basement (Figure 4.16) and Almas-Conceição do Tocantins domain. XS, GP and Au suite plot in the high-K field, not necessarily because they constitute a high-K series, but because this is not the appropriate diagram for classification of syn- to post collisional biotite \pm muscovite rich rocks, as is Aurumina suite (Botelho et al., 2006), and probably XS and GP. It is important to notice three samples from Aurumina suite that do not belong together in the field occupied by XS, GP and Au. These samples represent facies Au3 plot closer to the calc-alkaline domain, as it is composed by tonalites.. 


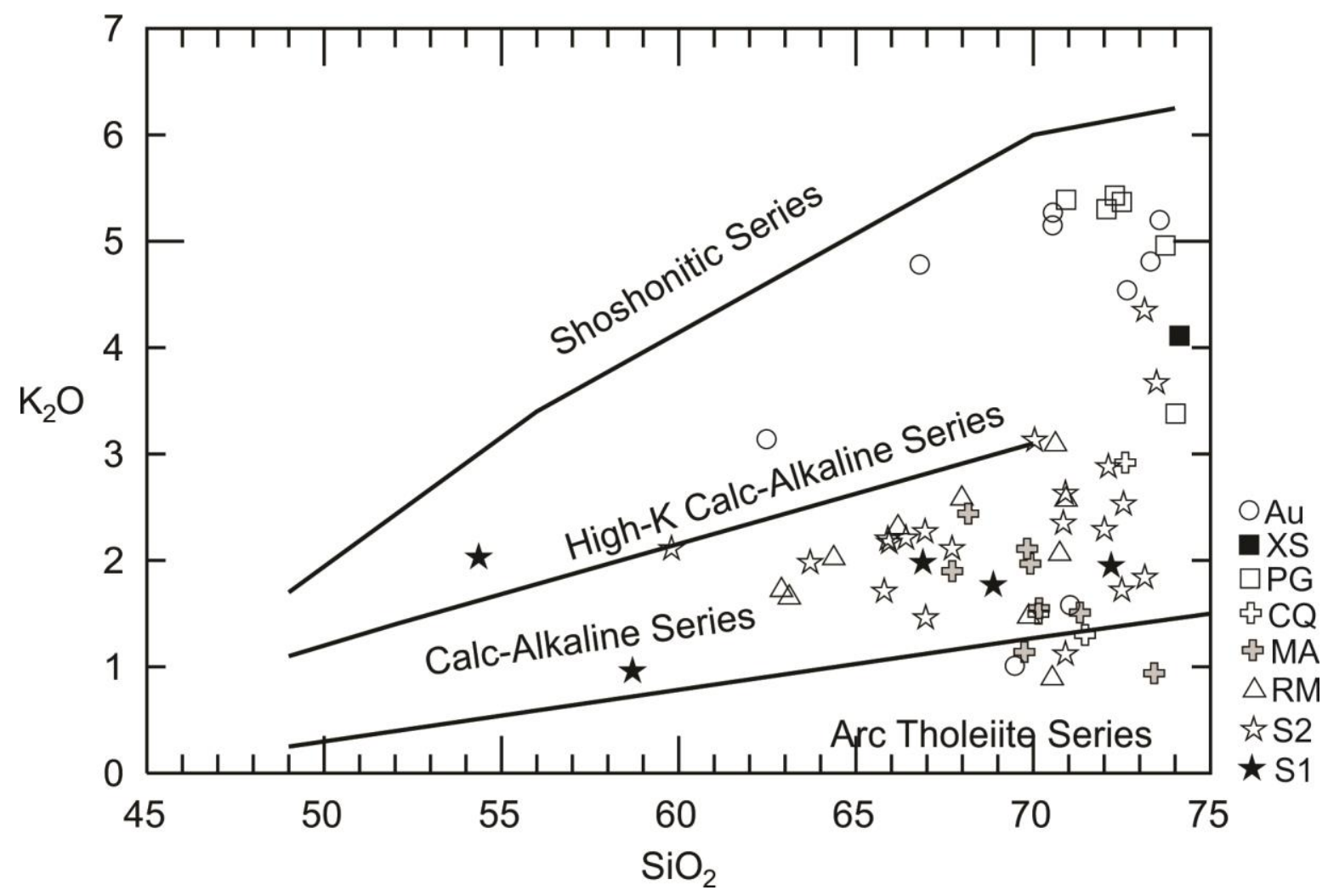

Figure 4.16: $\mathrm{SiO}_{2}$ vs $\mathrm{K}_{2} \mathrm{O}$ diagram (Peccerillo and Taylor, 1976).

Calc-alkaline evolutional trend for Natividade basement is evident in AFM diagram (Figure 4.17). Samples from Almas-Conceição do Tocantins and Cavalcante Arraias domains fit in the trend, regardless of their relation with Natividade basement.
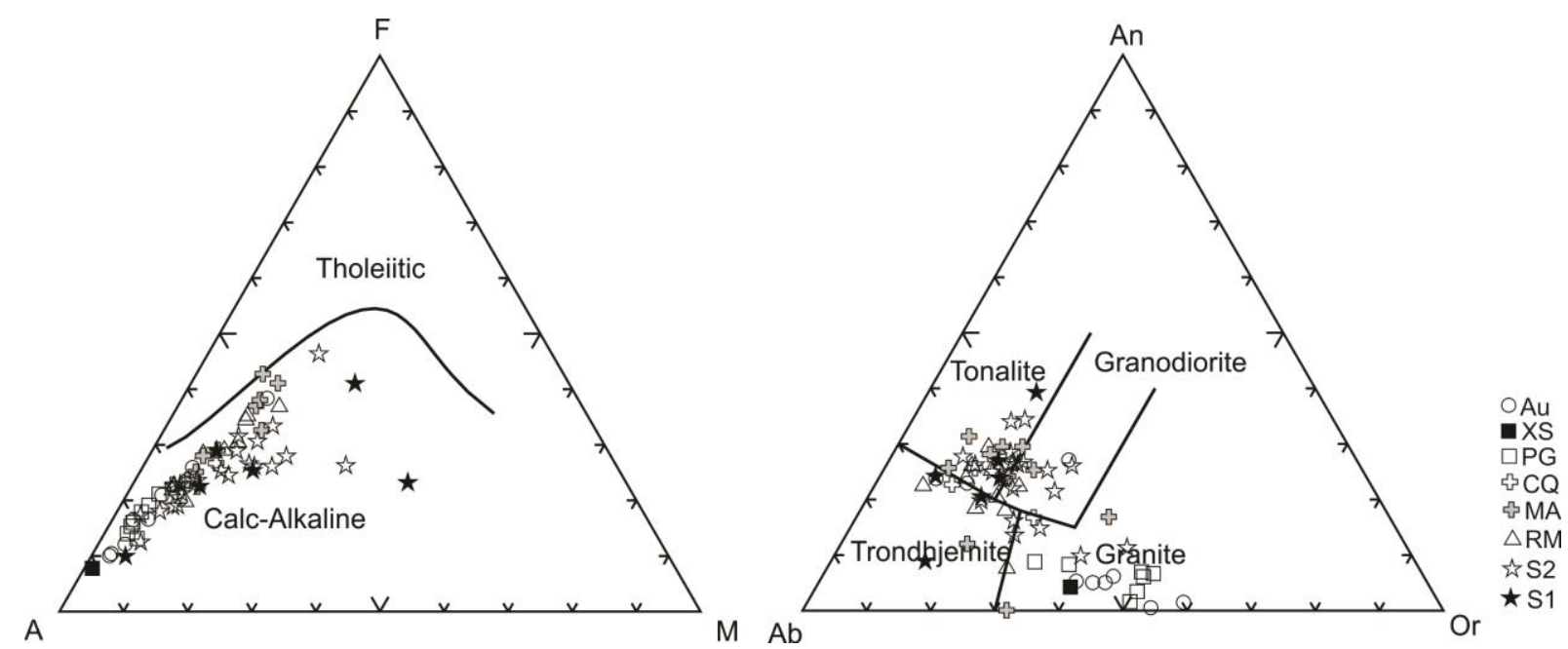

Figure 4.17: AFM (Irvine \& Baragar, 1971) and Felspar triangle (O’Connor, 1965). 
Presence of muscovite in suites from Natividade basement has given a hint about their peraluminous character, confirmed by whole rock geochemistry (Figure 4.18). In Natividade basement, RM has the lowest $\mathrm{A} / \mathrm{CNK}$ ratios, plotting in the metaluminous-peraluminous boundary. Other units spread out in the peraluminous field of the diagram, together with Aurumina suite and Suite 2 samples. Suite 1 presents the most metaluminous samples, but also has samples that plot in peraluminous field. $\mathrm{SiO}_{2}$ vs $\mathrm{ASI}$ graphic illustrates how Si-rich samples have progressively higher Aluminum saturation index (Figure 4.18).
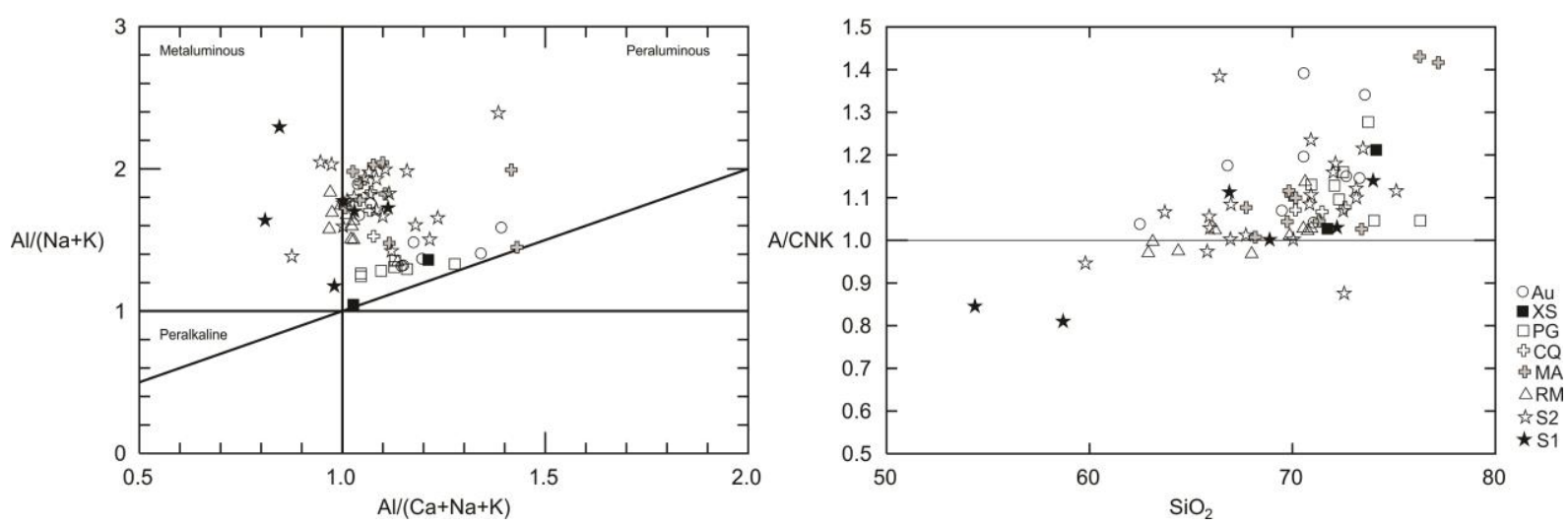

Figure 4.18: Aluminum Saturation Index (Shand, 1943) and $\mathrm{SiO}_{2}$ vs ASI.

Harker diagrams show how elements correlate with $\mathrm{SiO}_{2}$ (Figure 4.19 to Figure 4.23), and although not knowing yet if studied units belong to co-genetic suites, all samples are plotted in the same diagrams for comparison. $\mathrm{MgO}, \mathrm{CaO}, \mathrm{Al}_{2} \mathrm{O}_{3}, \mathrm{TiO}_{2}, \mathrm{Fe}_{2} \mathrm{O}_{3}, \mathrm{P}_{2} \mathrm{O}_{5}, \mathrm{Sr}, \mathrm{Fe}_{2} \mathrm{O}_{3}$ and $\mathrm{V}$ are negatively correlated with $\mathrm{SiO}_{2}$, meaning these elements behaved as compatible elements with early crystallizing mineral phases. Thus, for Almas-Conceição do Tocantins and Cavalcante-Arraias domains and Natividade basement, plagioclase, titanite and other mafic minerals were major fractionating phases in the evolution of the magmas. $\mathrm{K}_{2} \mathrm{O}$ and $\mathrm{Rb}$, instead, are positively correlated with $\mathrm{SiO}_{2}$.

Harker $\mathrm{SiO}_{2}$ vs $\mathrm{K}_{2} \mathrm{O}$ diagram, equivalent to Peccerillo and Taylor (1976), shows almost a horizontal trend for S1, S2, RM, MA and CQ, but XS, GP and Aurumina suite do not belong in the trend, for having higher contents of $\mathrm{K}_{2} \mathrm{O}$. This observation is valid for $\mathrm{SiO}_{2} \mathrm{vs}$ $\mathrm{Rb}$ diagram, where $\mathrm{XS}, \mathrm{GP}$ and $\mathrm{Au}$ have the highest contents of $\mathrm{Rb}$. 

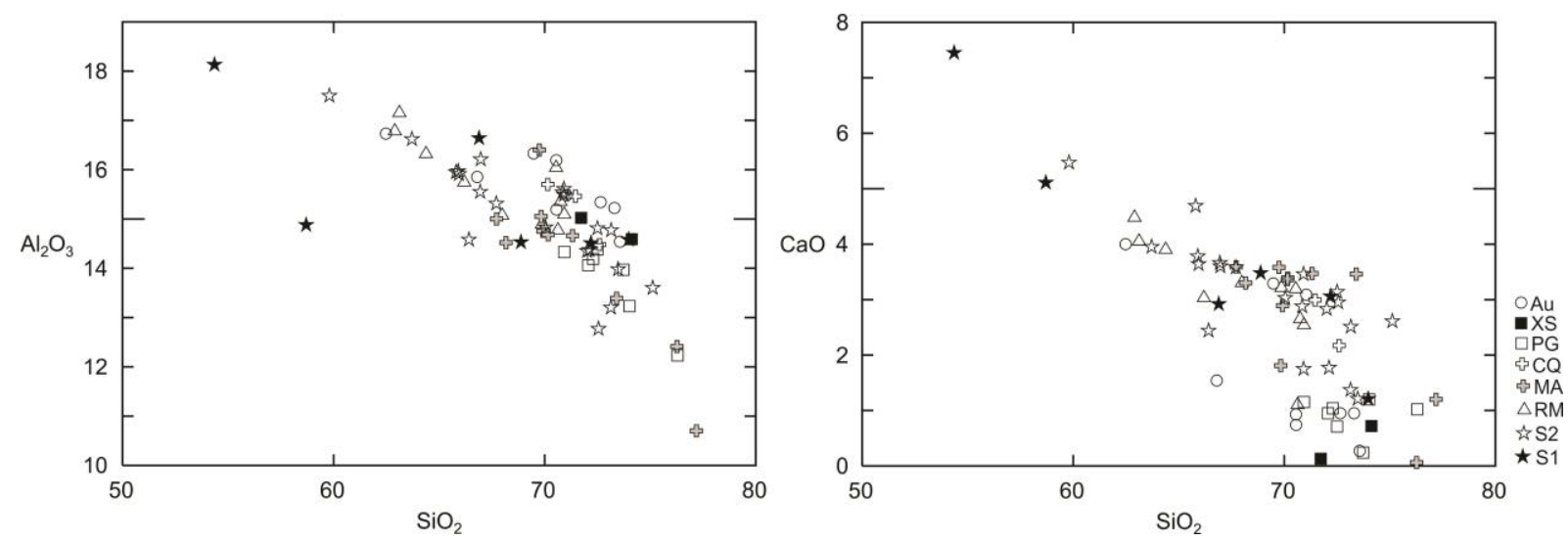

Figure 4.19: Harker diagrams.
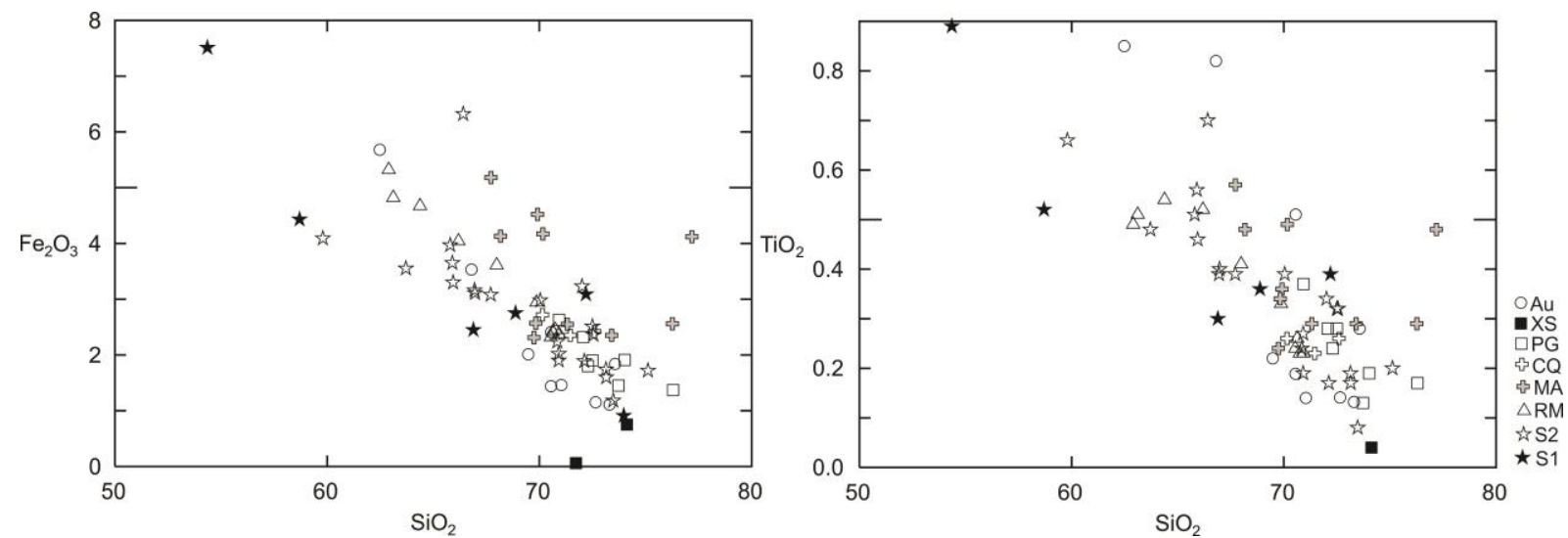

Figure 4.20: Harker diagrams.
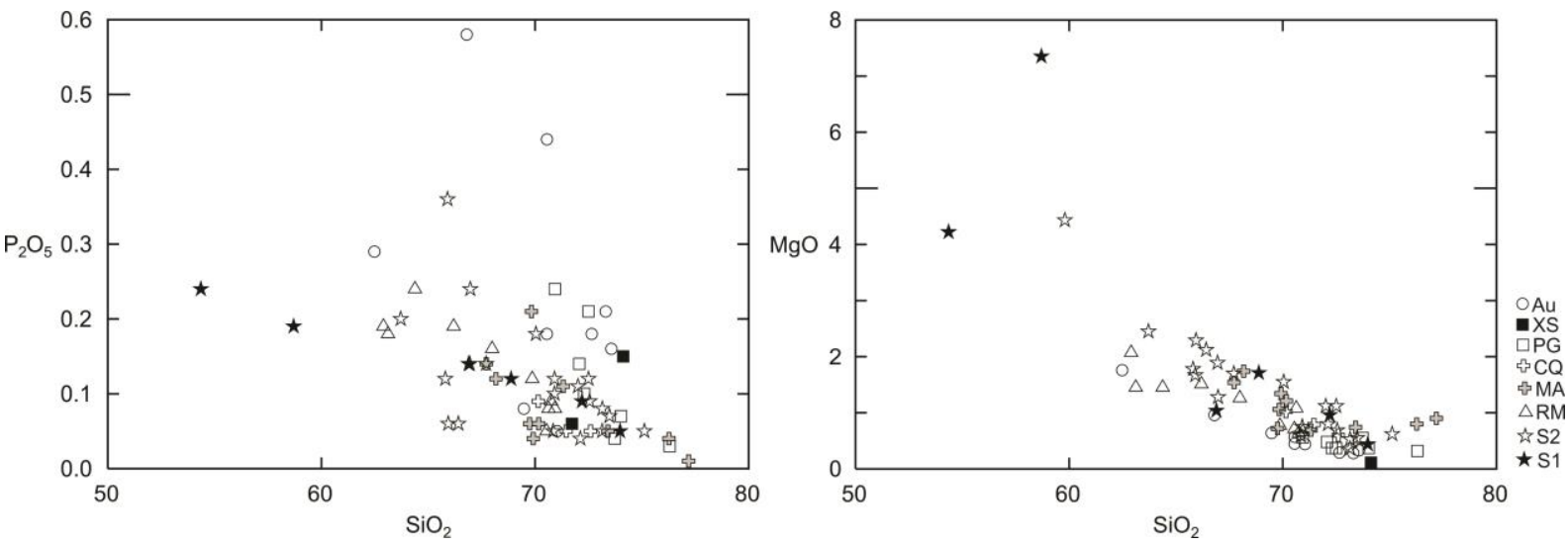

Figure 4.21: Harker diagrams. 

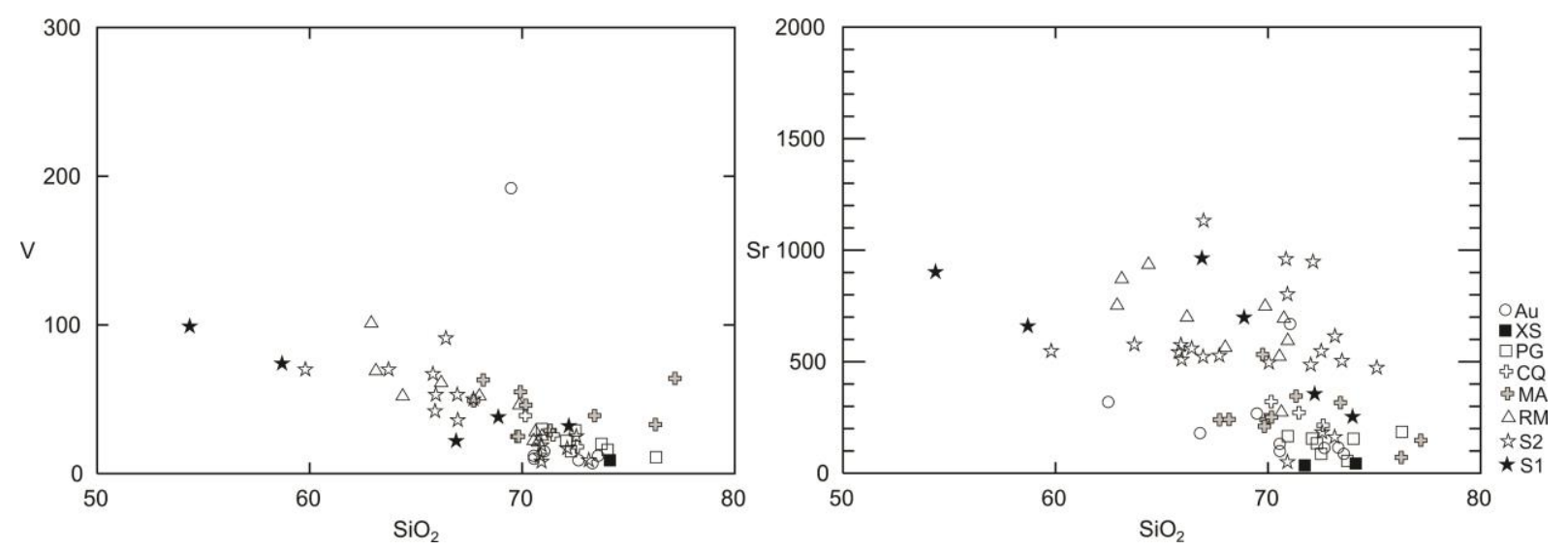

Figure 4.22: Harker diagrams.
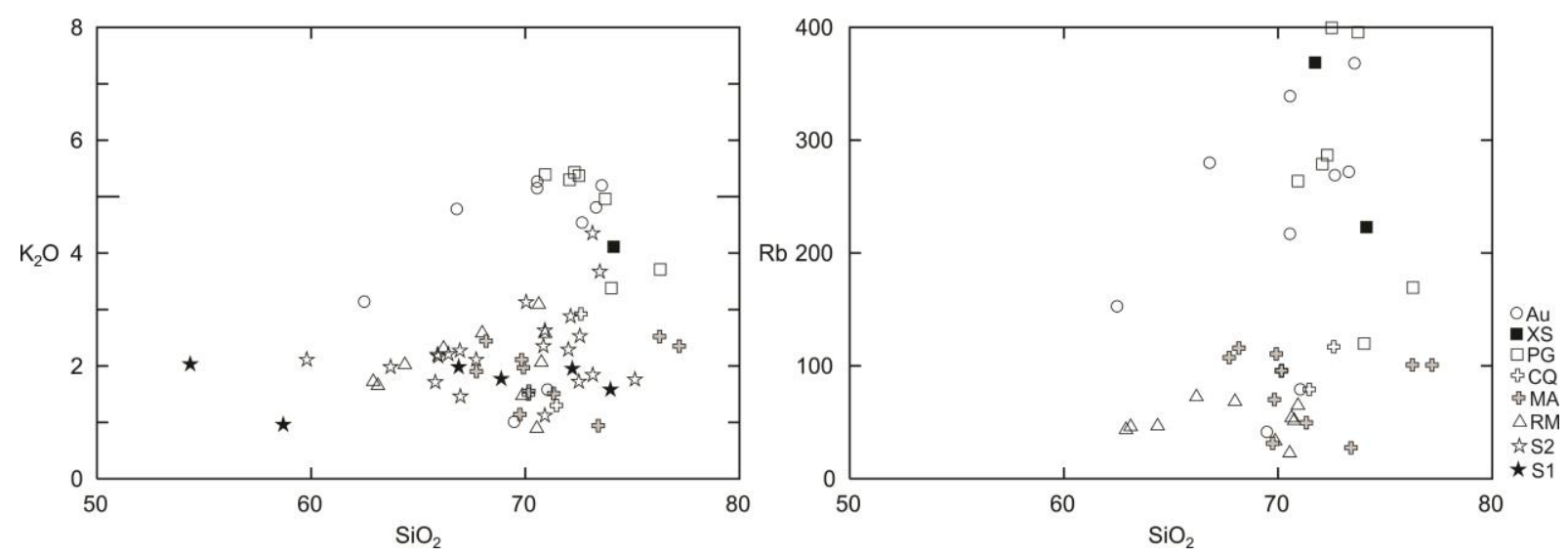

Figure 4.23: Harker diagrams.

Chappel \& White (1974) defined two groups of magmatic rocks in Lachland fold belt, Australia: the S-type and the I-type granites. Since then, this classification has been applied to resembling areas. Extensive studies in Aurumina suite indicate it corresponds to an S-type suite (Botelho et al., 2006). $\mathrm{K}_{2} \mathrm{O}$ vs $\mathrm{Na}_{2} \mathrm{O}$ diagram (Chappel \& White, 2001) highlights how Príncipe Granite and Xobó suite resemble Aurumina suite and are plotted preferentially within S-type granites area (Figure 4.24). The FeOt vs $\mathrm{CaO}$ graphic also shows how Príncipe Granite and Xobó suite behave more likely as S-type than I-type granites (Figure 4.24).

In FeOt vs $\mathrm{CaO}$, samples from $\mathrm{S} 1, \mathrm{~S} 2, \mathrm{RM}, \mathrm{MA}$ and $\mathrm{CQ}$ occupy both field of S an Itype granites, but our interpretation is Ca loss was an important factor during metamorphic events, and not that these rocks were formed by partial melting of crustal material, as Sm and $\mathrm{Nd}$ isotopic signatures will demonstrate. Thereby, these rocks are more similar to I-type granites. 

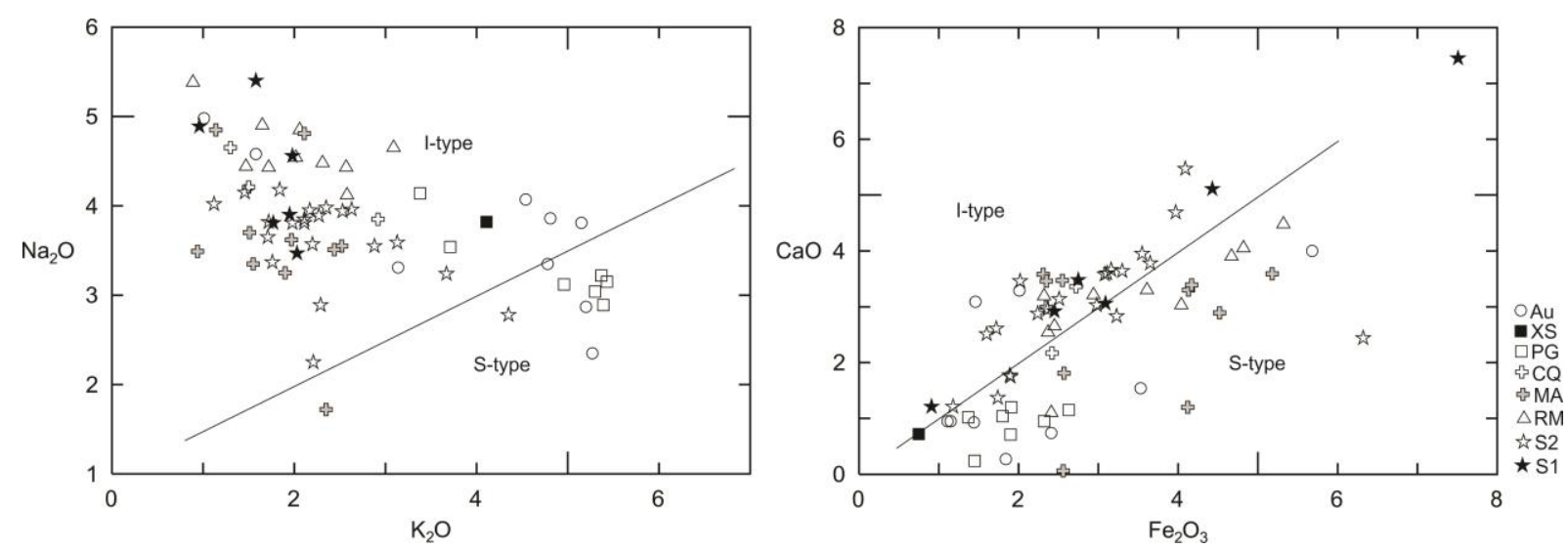

Figure 4.24: $\mathrm{K}_{2} \mathrm{O}$ vs $\mathrm{Na}_{2} \mathrm{O}$ and $\mathrm{FeO}$ (total) vs $\mathrm{CaO}$ (Chappell \& White, 1974).

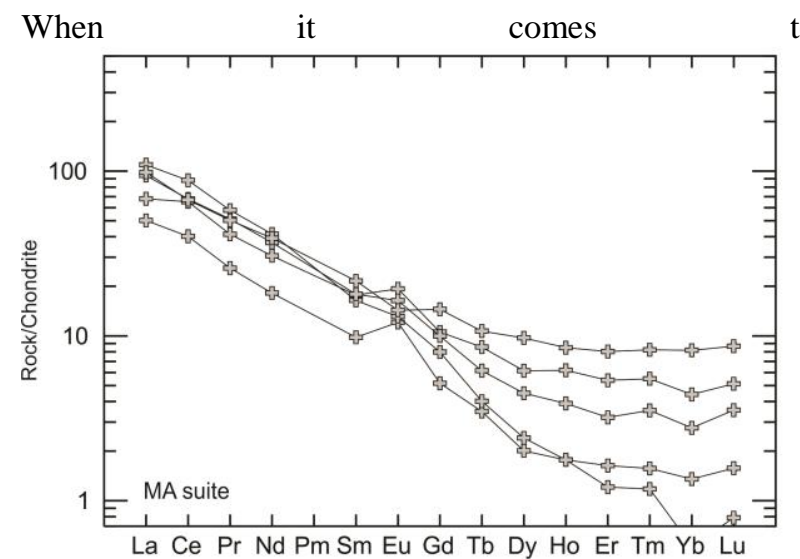

to
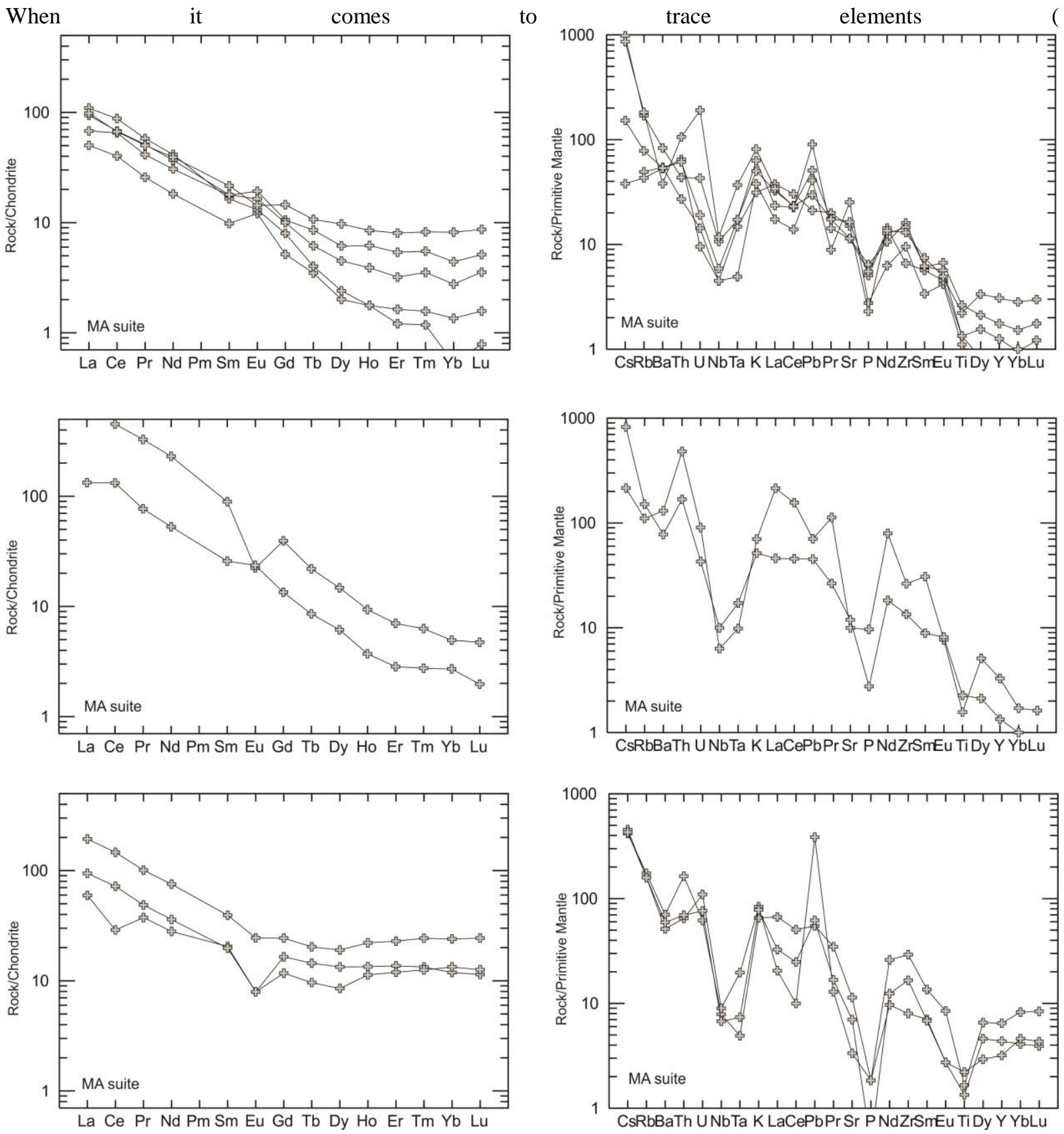

Figure 4.26: REE and multielementar spidergram of MA suite (Sun \& McDonough, 1989). 

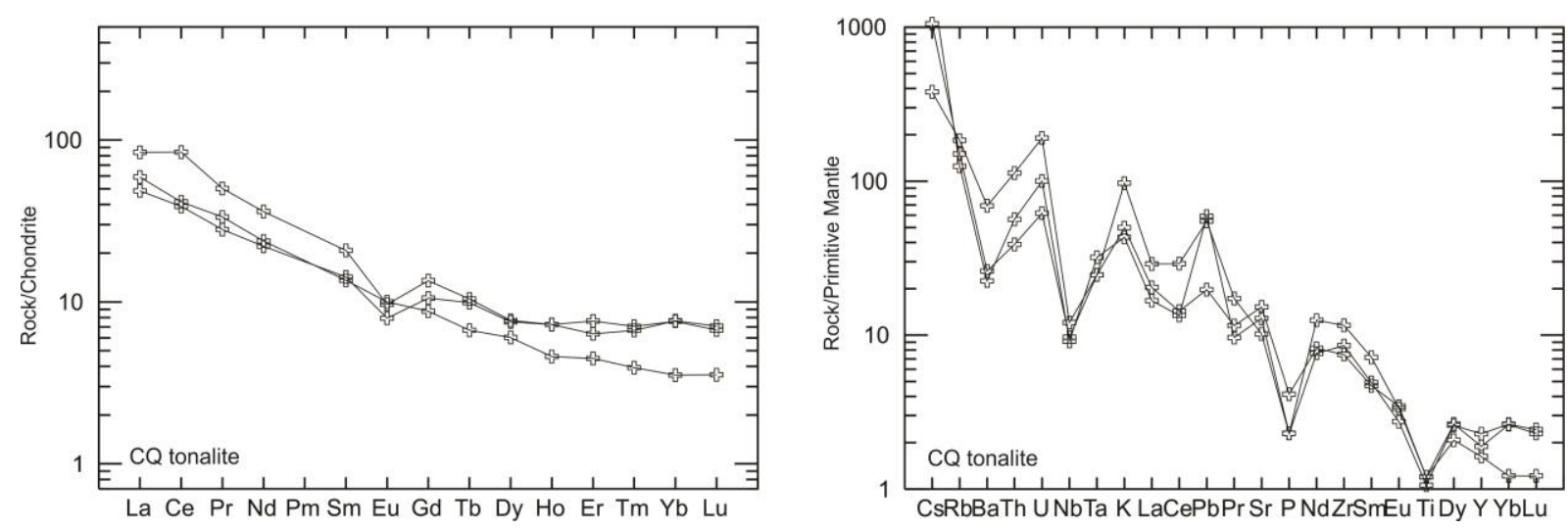

Figure 4.27), analyses are more assertive as these elements are less mobile in aqueous fluids. RM suite has a homogeneous multielementar pattern. REE spidergram for RM suite is very uniform and reveals a hundred times enrichment in LREE, while enrichment in heavy REE is less than ten times, relative to chondrite. Heavy REE present a slightly sloped alignment. Eu negative anomaly is practically inexistent, suggesting a primitive character for this unit.

MA samples have a less uniform behaviour in REE and multielementar spidergrams, and can be divided in three groups of different REE pattern. The first group has LREE enrichment bellow a hundred times, has little Eu anomaly - positive or negative - and is depleted in HREE, as no sample reaches ten times enrichment in HREE.

The second group is more than a hundred times enriched in LREE, has higher Eu negative anomalies, and has the steepest slope, being depleted in HREE. CQ tonalite pattern (Figure 4.27) is similar to the first group of MA suite. The third group has a higher content of HREE than the first, tends to have higher Eu negative anomaly, but what differentiates it from the other two groups is its horizontal HREE pattern with an enrichment of ten times chondrite values.
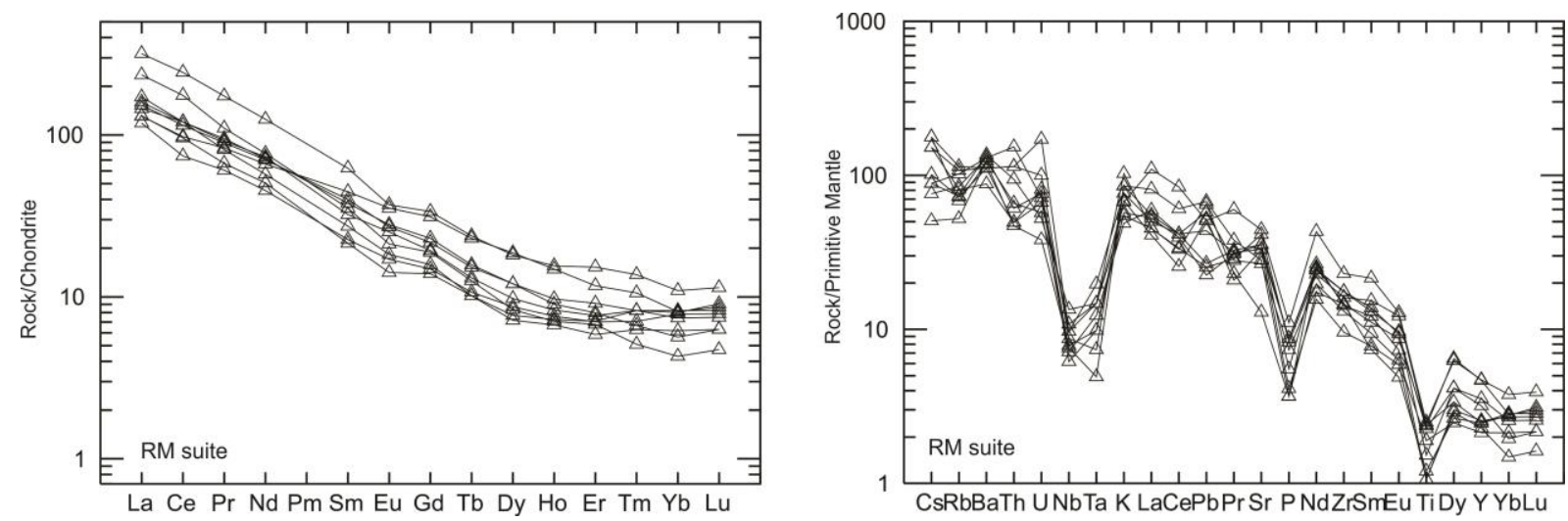

Figure 4.25: REE and multielementar spidergram of RM suite (Sun \& McDonough, 1989). 

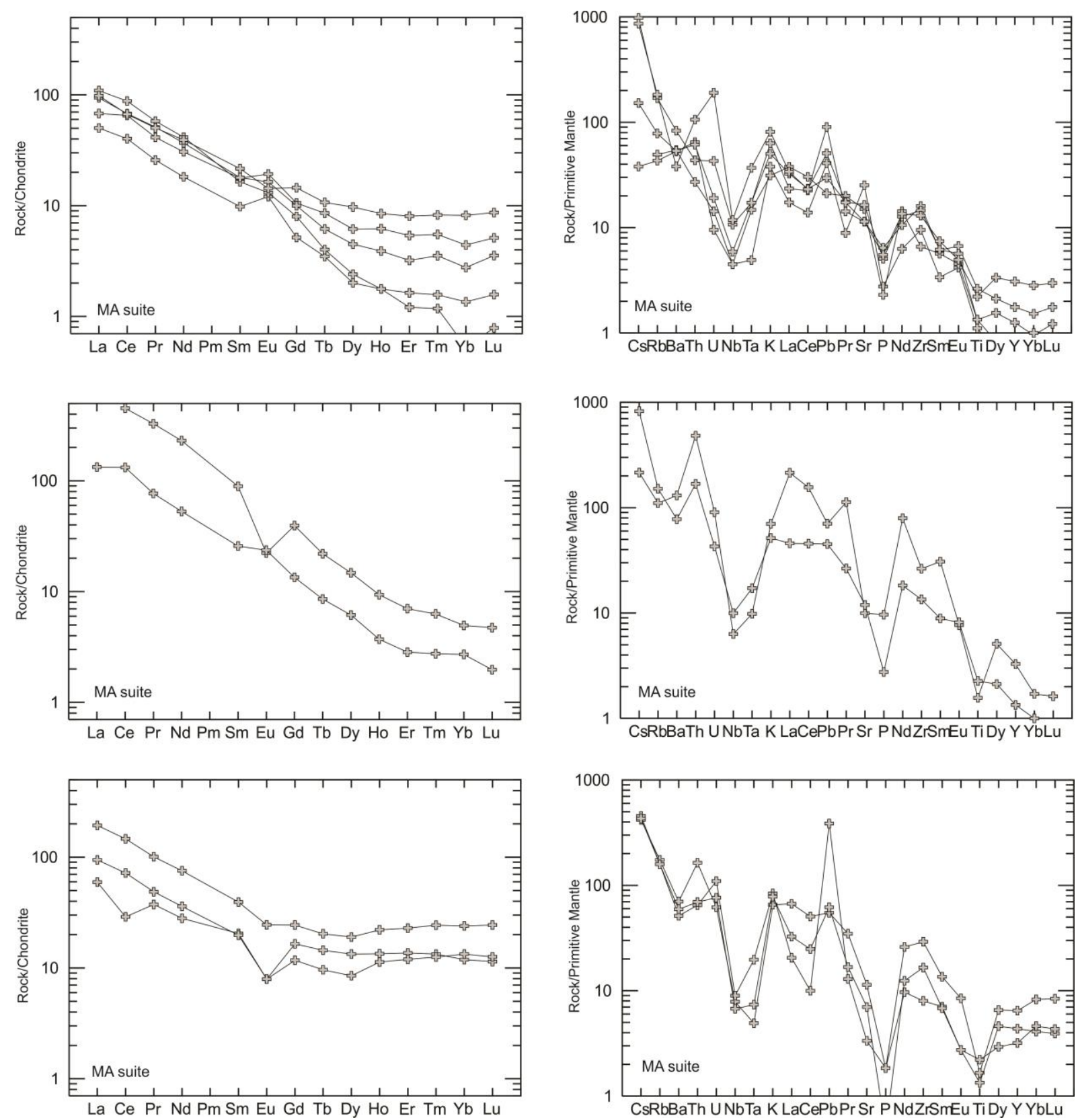

Figure 4.26: REE and multielementar spidergram of MA suite (Sun \& McDonough, 1989).
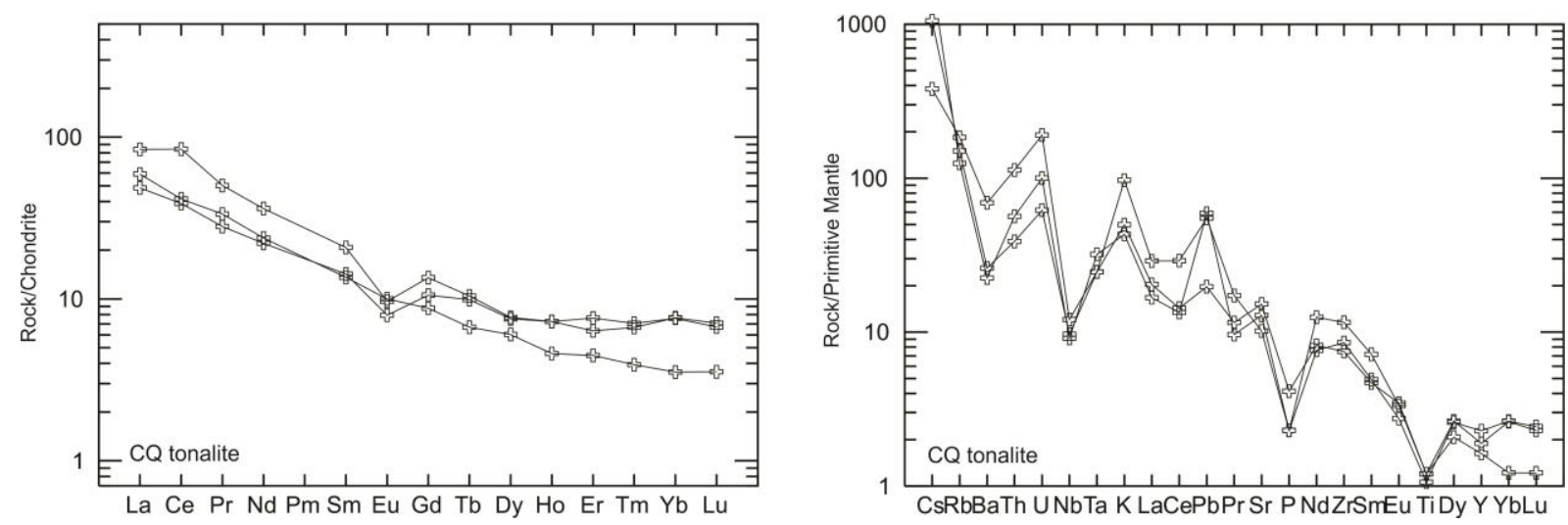

Figure 4.27: REE and multielementar spidergram of CQ tonalite (Sun \& McDonough, 1989). 
Príncipe Granite and Xobó have the same pattern (Figure 4.28). They have high negative $\mathrm{Eu}$ anomalies and a steep alignment. Muiltielementar spidergram shows they are almost a thousand times enriched in large litophile elements relative to primitive mantle.
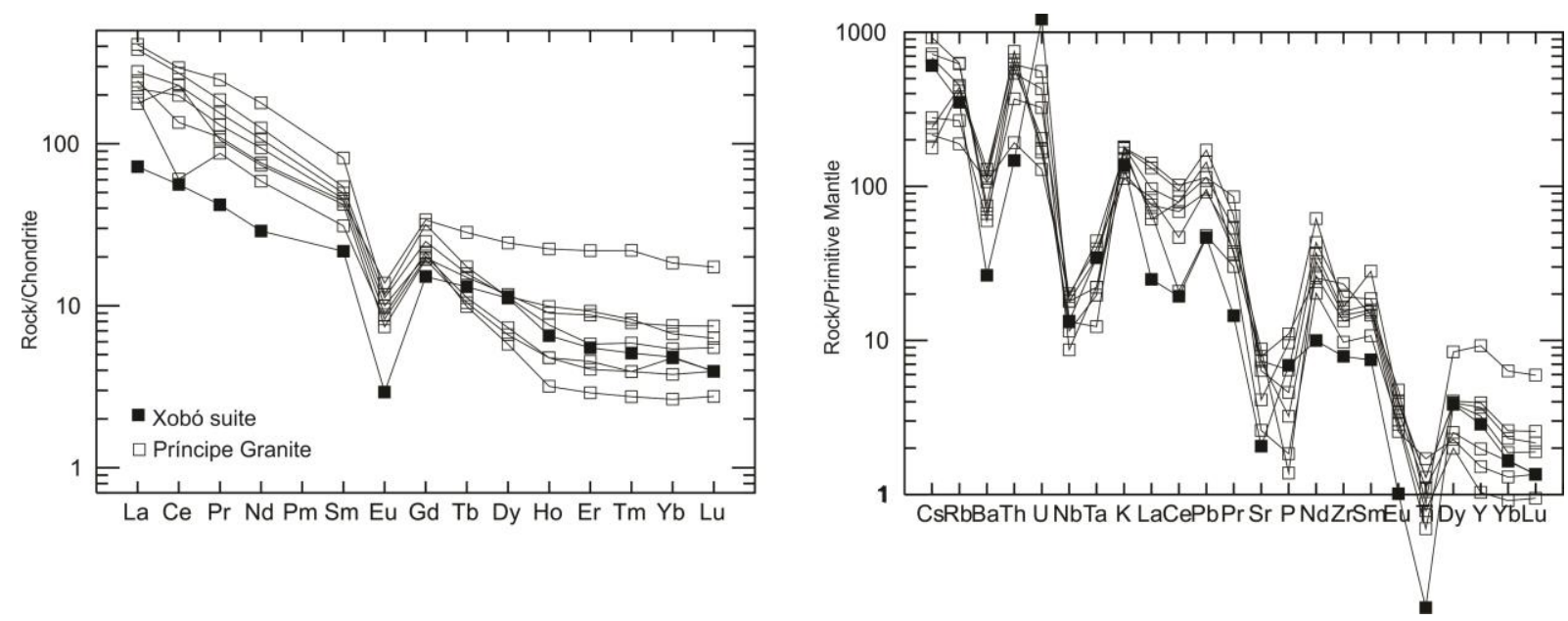

Figure 4.28: REE and Multielementar spidergrams ofXS and PG (Sun \& McDonough, 1989).

Suite 1 and Suite 2 have similar contents of LREE, around a hundred times chondrite values, but their HREE content is different: Suite 2 is more depleted in HREE (Figure 4.29). Their multielementar diagrams are not used, as many elements were not analysed by the time the paper that presented chemistry of this rocks was published (Cruz, 1993).
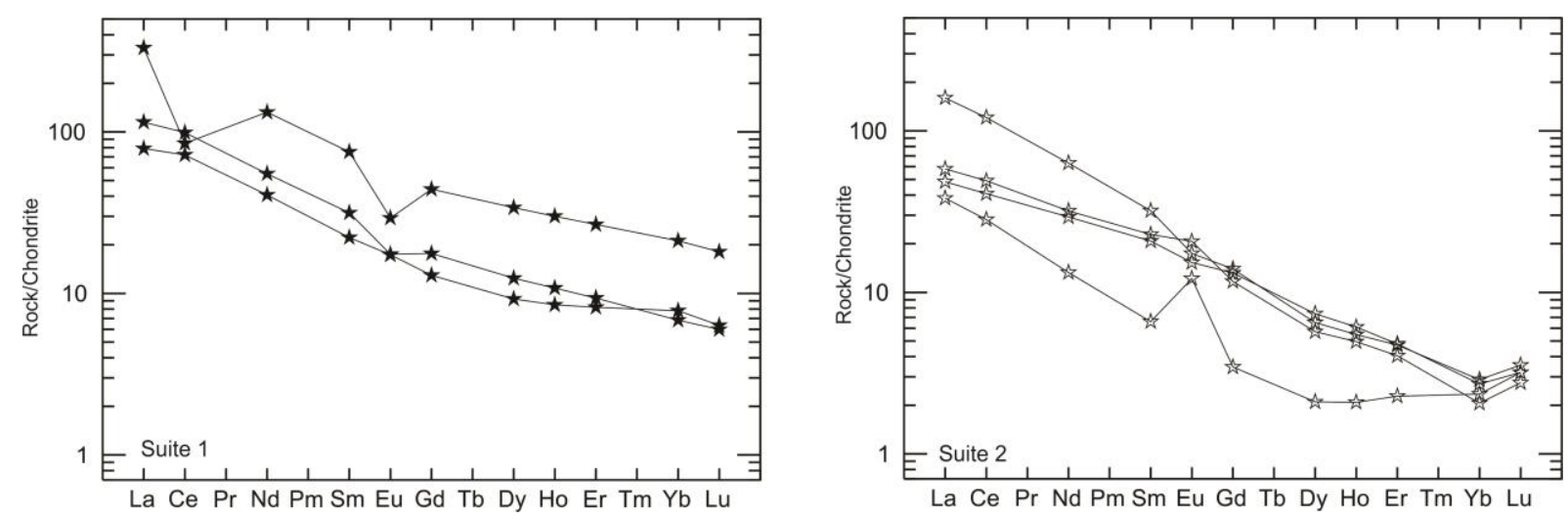

Figure 4.29: REE spidergram of S1 and S2 (Sun \& McDonough, 1989), data from Cruz (1993).

Aurumina suite granites, facies Au1 and Au2, reveal a REE pattern similar to Príncipe Granite and Xobó suite. When only granitic samples (Au1 and Au2) from Aurumina suite are compared to Príncipe granite and Xobó suite, the pattern observed is utterly homogeneous. These rocks have the same order of magnitude of enrichment in LREE and depletion in HREE, and the same Eu negative anomaly (Figure 4.30). Au3 facies is different, almost does not reach a hundred times encrichment in LREE relative to chondrite and has no Eu anomaly. 

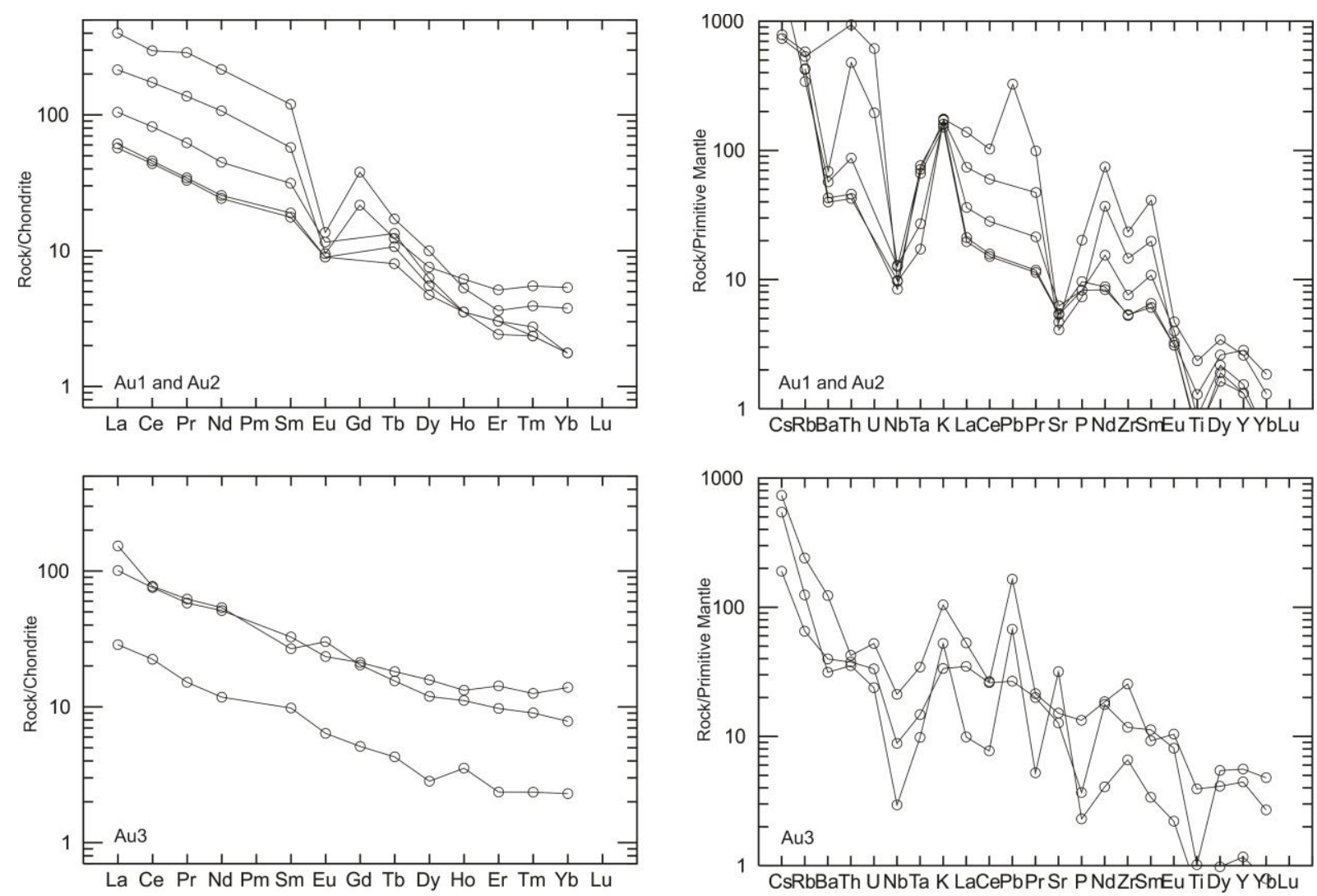

Figure 4.30: Multielementar and REE spidergrams for Aurumina suite (Sun \& McDonough, 1989).

Knowing chemical signature of these rocks, we now discuss tectonic environment in which they probably formed. Pearce et al. (1984) diagrams define, based on trace elements, empirical fields of tectonic environment. Although fields were defined by and for Phanerozoic rocks, diagrams have been extensively used in the literature for Proterozoic rocks, as they provides coherent propositions.

Geologic units studied and compared in this paper occupy the fields of volcanic arc and syncollisional granites of Pearce et al. (1984) diagram (Figure 4.31). Xobó suite, Príncipe Granite and facies Au1 and Au2 of Aurumina suite cluster mainly in the domain of syncollisional granites (syn-COLG). RM, MA, CQ, S1, S2 and facies Au3 from Aurumina suite spread rather in the volcanic arc field (VAG). 

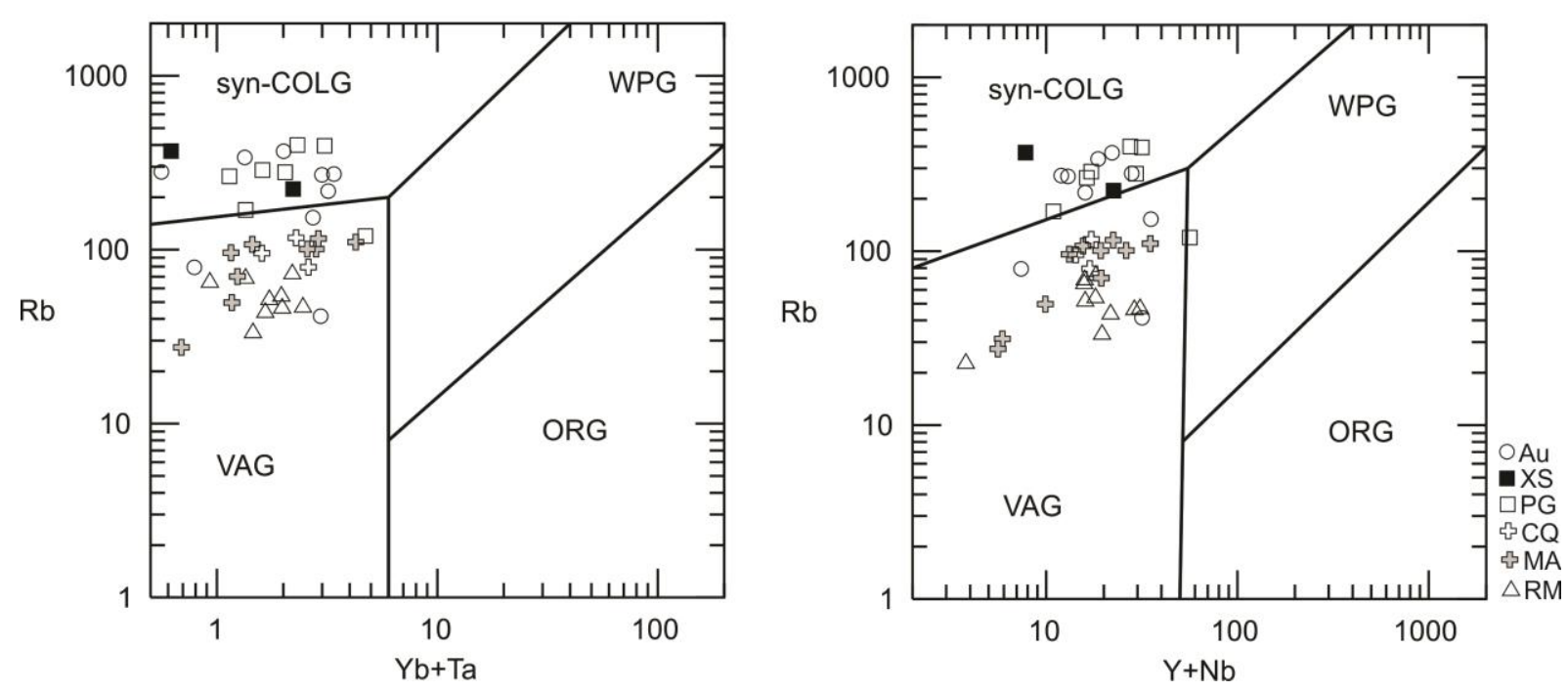

Figure 4.31: Tectonic discrimination diagrams (Pearce et al., 1984).

\subsubsection{Sm-Nd}

Sm-Nd results supplement geochemistry data and permit us infer more about crustal evolution. Figure 4.32 presents results of one representative sample of each studied unit from Natividade basement.

The most notable feature in Figure 4.32 is that XS and PG have similar TDM ages, 2.81 and $2.83 \mathrm{Ga}$ respectively, and with an igneous crystallization at 2.15 and $2.12 \mathrm{Ga}$, both units have clearly negative $\varepsilon_{\mathrm{Nd}}$ values.

RM, MA and CQ tonalite, in turn, have similar TDM ages and with a crystallization between 2.23 and $2.16 \mathrm{Ga}$, their $\varepsilon_{\mathrm{Nd}}$ values are not as negative as Xobó and Príncipe Granite, but closer to zero or slightly positive. 


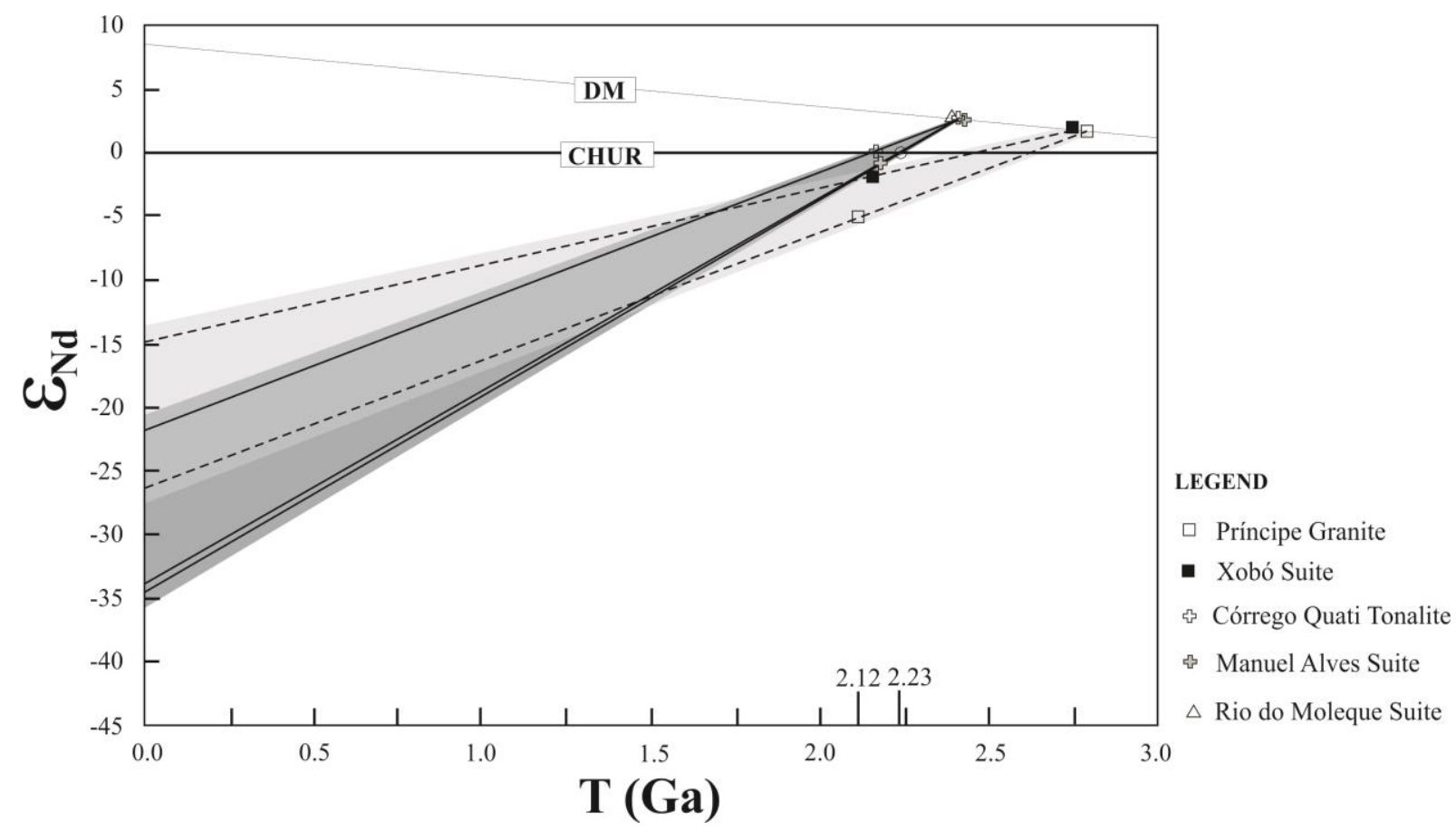

Figure 4.32: Nd isotopic evolution diagram of Natividade basement. One representative sample of each unit is presented.

When all analysed samples are plotted in $\mathrm{T}(\mathrm{Ga})$ vs $\varepsilon_{\mathrm{Nd}}$ graphic, the result is not as simple as in Figure 4.32, because samples from the same unit have a wider range of TDM ages and $\varepsilon_{\mathrm{Nd}(\mathrm{t})}$ values (Figure 4.33). However, what is important to notice is that Xobó suite

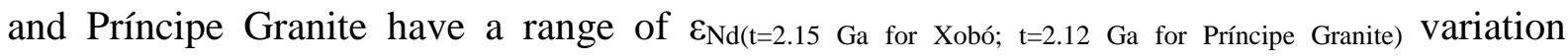
essentially within negative values: -5.13 to -0.26 .

RM suite values of $\varepsilon_{\mathrm{Nd}(\mathrm{t}=2.23)}$ vary from -1.99 to 0.2 . MA suite has $\varepsilon_{\mathrm{Nd}(\mathrm{t}=2.18)}$ from -3.2 to 2.04 and CQ tonalite $\varepsilon_{\mathrm{Nd}(\mathrm{t}=2.16)}$ is between -0.23 and 0.46 .

Cruz (2001) presents data for S1 and S2, and Botelho et al. (2006) for Aurumina suite. $\varepsilon_{\mathrm{Nd}(t=2.20)}$ for $\mathrm{S} 1$ is between -1.37 and $-0.15, \varepsilon_{\mathrm{Nd}(\mathrm{t}=2.20)}$ for $\mathrm{S} 2$ is -4.95 to -0.88 and $\varepsilon_{\mathrm{Nd}(\mathrm{t})}$ is -3 to 1 in Aurumina suite. 


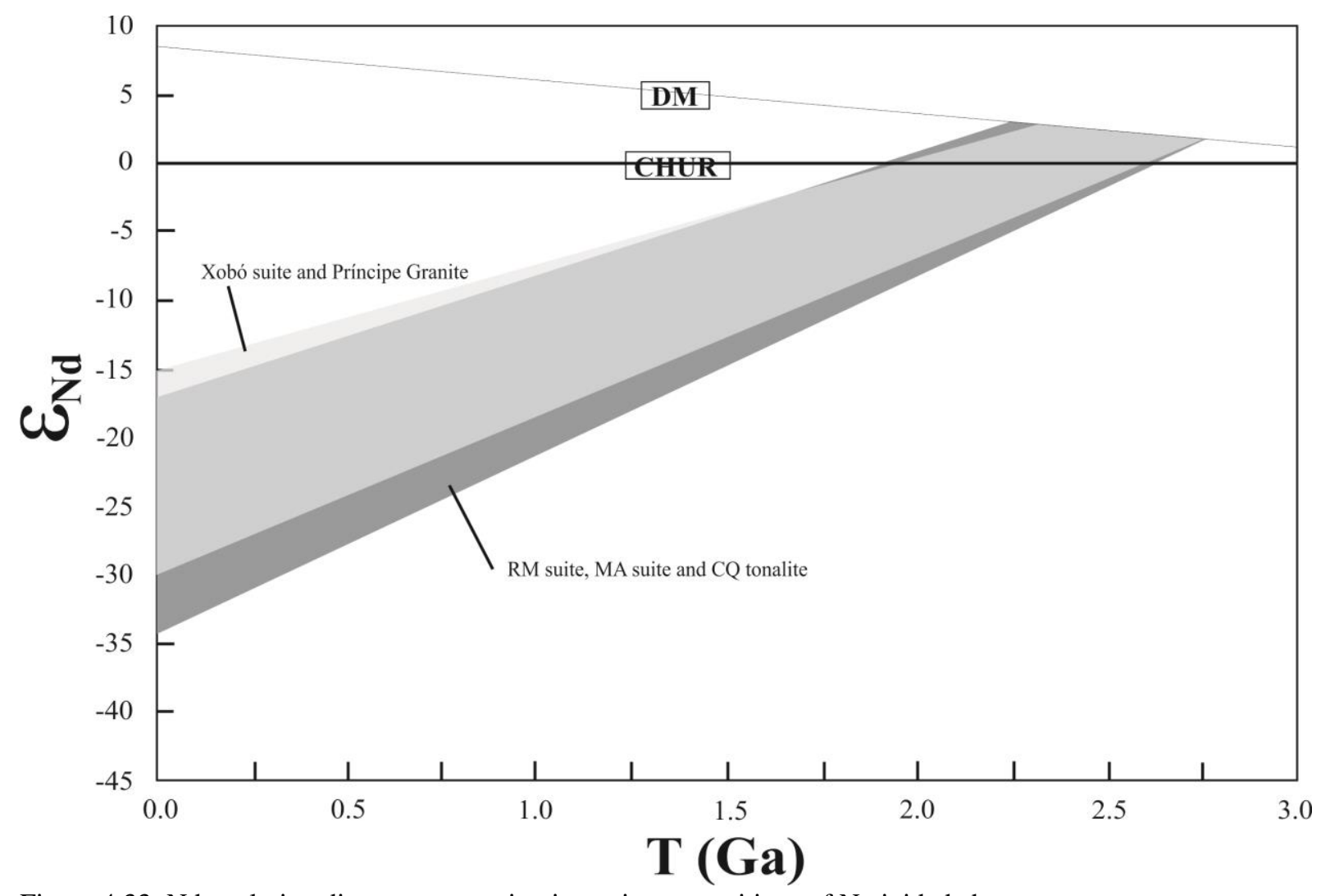

Figure 4.33: Nd evolution diagram comparing isotopic compositions of Natividade basement.

\subsection{Petrogenetic aspects}

Based on $\mathrm{U}-\mathrm{Pb}$ results, it is possible to recognize four stages of magmatism. The first, older than $2.3 \mathrm{Ga}$, one between 2.2 and $2.3 \mathrm{Ga}$, another stage between 2.16 and $2.18 \mathrm{Ga}$ and the last one between 2.12 and $2.15 \mathrm{Ga}$.

Evidence for the first event is sample G3, which yield an upper intercept at $2446 \pm 68$ Ma. Cruz (2001) reports an age of $2455 \pm 14 \mathrm{Ma}$ in titanite grains from a unit apart from S1 and S2, the Ribeirão das Areias Complex. Inicially, we did not fancy this $2.45 \mathrm{Ga}$ analysis as titanite incorporates relatatively high contents of non-radiogenic $\mathrm{Pb}$ and can vary its $\mathrm{REE}$ content due to thermodynamic stresses (Green \& Pearson, 1987; Horstwood et al., 2003; Simonetti et al.,2006). Nevertheless, zircon age found in sample G3 led us to believe Cruz data are significant and that there may exist an older basement, Siderian in age, but of which we do not have further data.

Fuck et al. (2014) also present ages greater than $2.3 \mathrm{Ga}$ for samples in Almas-

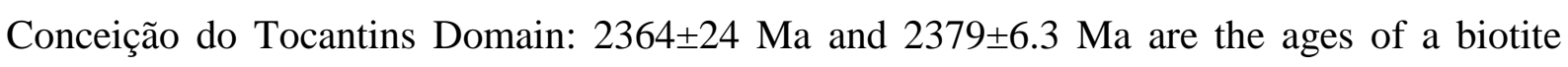
tonalite and a granite-gneiss, respectively.

Sample G2, Príncipe Granite, also shows an alignment of zircon grains intercepting Concordia at $2328 \pm 34 \mathrm{Ma}$, interpreted as inheritance. Thus, these grains could represent 
assimilation from country rocks during emplacement and support the existence of a Siderian core.

The second stage of magmatism occurred between $2.2 \mathrm{Ga}$ and $2.3 \mathrm{Ga}$ and is represented by samples from RM suite, S1 and S2 (Cruz, 2001).

The third stage of magmatism was between 2.16 and 2.18, shown in dated samples from MA suite and CQ tonalite. Lastly, the fourth stage of magmatism occurred at 2.12-2.15 Ga, when Xobó suite and Príncipe Granite intruded older rocks. Available data for Aurumina suite indicate crystallization ages between 2.12 and $2.17 \mathrm{Ga}$ (Botelho et al., 2006).

Finally, after recognizing these granitogenesis phases, we question which was the mechanism responsible for this magmatism.

Beginning with the younger units, Aurumina suite is assumed to be a syn- to postcollisional suite (Botelho et al., 2006). We propose that Xobó suite and Príncipe Granite are correlate units to Aurumina, for being peraluminous, having the most negative values of $\varepsilon_{\mathrm{Nd}}$ and occupying the field of syn-collisional granites in tectonic discrimination diagrams diagrams(Pearce et al.,1984). In addition, ages proposed for Aurumina suite are equivalent to ages found in this paper. Thus, the set of characteristics of these rocks are coherent with the interpretation of these granites being a product of crustal melting. Xobó suite and Príncipe granite are both muscovite-biotite granites, and fit in classification of facies Au2 (Botelho et al., 2006).

One difference between Aurumina suite outcropping near Cavalcante and the units in Natividade basement is that Aurumina forms greisen deposits with tin mineralization (Alvarenga et al., 2007). This is not observed nearby Natividade, and makes us believe rocks in Natividade correspond to intrusions in deeper crustal levels, greater than what is required for exsolution of a fluid phase responsible for greisenization.

Despite their common peraluminous character, other units - S1, S2, RM, MA and CQ - do not share chemical characteristics with X, Príncipe and Aurumina. None of these rocks plot in the syn-collisional field of the diagram (Figure 4.31) and they do not have $\varepsilon_{\mathrm{Nd}}$ values as negative as the syn-collisional rocks.

In Peccerillo and Taylor diagram (1976), syn-collisional rocks belong in the field of high-K series. This happens because these rocks derived from relatively low melting rate of crustal material, where $\mathrm{K}$ is easily partitioned into the melt for its high incompatibility. The high $\mathrm{K}$ content is evidenced by the presence of biotite, muscovite and $\mathrm{K}$-feldspar in $\mathrm{X}, \mathrm{PG}$ and $\mathrm{Au}$. In contrast, S1, S2, RM, MA, CQ and Au3 samples, belong in the calc-alkaline trend. 
Botelho (2006) affirms Au3 is a syn to post-collisonal tonalite, and plots as VAG because it is not a granite.

One plausible mechanism to explain the generation of tonalites from S1, S2, RM, MA and CQ is the development of one or more magmatic arc during Rhyacian.

Could these rocks - S1, S2, RM, MA and CQ- represent a TTG terrane, as they are Paleoproterozoic and intrusive in volcano-sedimentary sequences? Our answer is probably no. S1 and S2 were previously studied and have been classified as TTG rocks, but they do not present a sodic affinity, and seem to evolve through K-enrichment, as calc-alkaline series do (Figure 4.34).

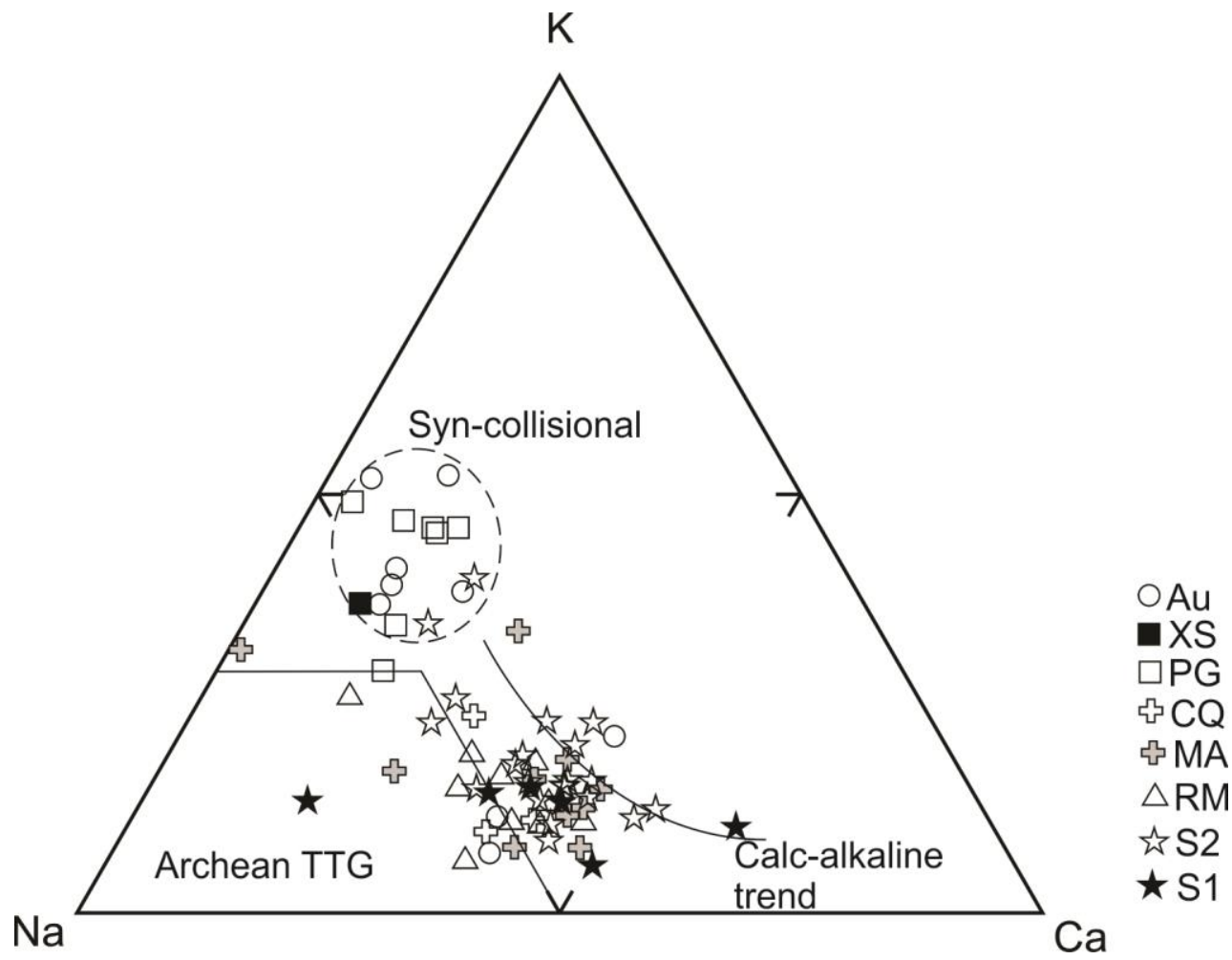

Figure 4.34: Cationic Na-K-Ca diagram (Nockolds \& Allen, 1953)

RM, MA, CQ and Au3 fit in the calc-alkaline evolutional trend (Nockolds \& Allen, 1953), unlike Archean TTG rocks, that plot closer to the Na apex and do not show a clear differentiation (Moyen \& Martin, 2012).

Therefore, S1, S2, RM, MA and CQ could have evolved in "ordinary" arc systems. However, these systems probably evolved during time as well as magmatism. Contamination and fractional crystallization are two mechanisms that could justify differences in REE pattern between suites. Although Au3 fit in the trend of magmatic arc rocks, Botelho (2006) extensive studies of Aurumina suite classify it as syn- to post collisional tonalites. 
Data are ambiguous to determine whether the different suites evolved in an island arc or in a continental arc. Our interpretation is that $\mathrm{S} 1$ has a primitive character, closer to rocks in island arcs or intrusive in a proto crust that could be the Siderian core mentioned. This Siderian basement could even have a TTG signature, but that is all conjectural.

$\mathrm{S} 2$ and $\mathrm{RM}$ are more evolved than $\mathrm{S} 1$, but still have a primitive character, seen in Na$\mathrm{K}-\mathrm{Ca}$ triangle and in the REE diagram. The absence of Eu anomaly in RM can be interpreted as absence of plagioclase in the relict or rapid ascention and emplacement through a thin crust, where fractional crystallization did not retain plagioclase in early phases.

According to Cruz (2001), melting of ultramafic rocks generated Suite 1 and melting of basalts generated Suite 2, contemporarily. But it is possible that both suites evolved from the same parental magma: S1 crystallized amphibole because of its higher content of normative $\mathrm{Ca}$, and when $\mathrm{Ca}$ is consumed, $\mathrm{Al}$ is available for biotite crystallization. $\mathrm{RM}$ suite is, somehow, between S1 and S2: the absence of amphibole and Eu anomaly resembles S2, but higher contents of REE, especially HREE, resembles S1. RM should be classified as S2 based on Cruz (1993) criteria: the absence of amphibole. S1, S2 and RM are, therefore, spatially and chronologically related.

MA undifferentiated suite is very heterogeneous, but what is important to notice is that, unlike RM suite, it that, unlike RM suite, it shows notably more evolved magmas. Samples with greater LREE content, steeper REE content, steeper REE pattern and higher Eu anomalies are quite different from samples in RM suite ( 
suite
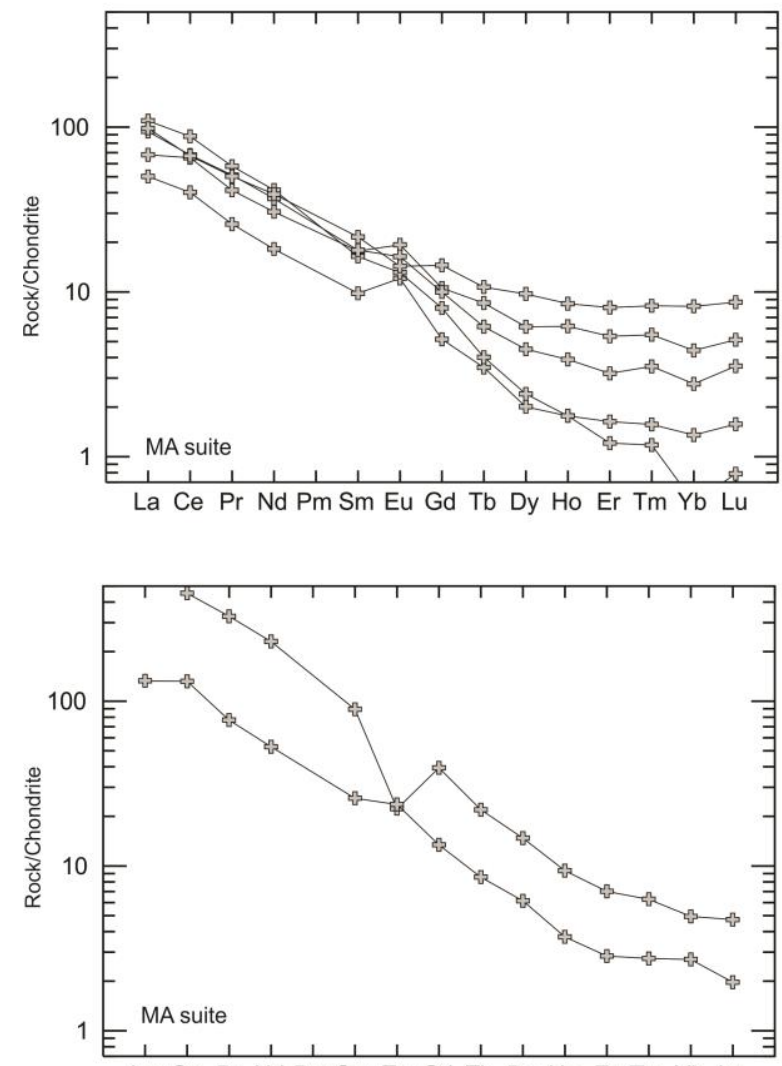

La Ce Pr Nd Pm Sm Eu Gd Tb Dy Ho Er Tm Yb Lu

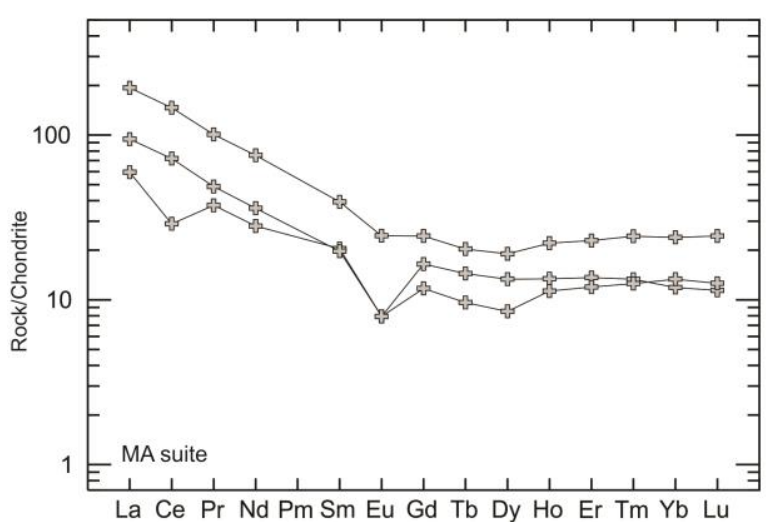

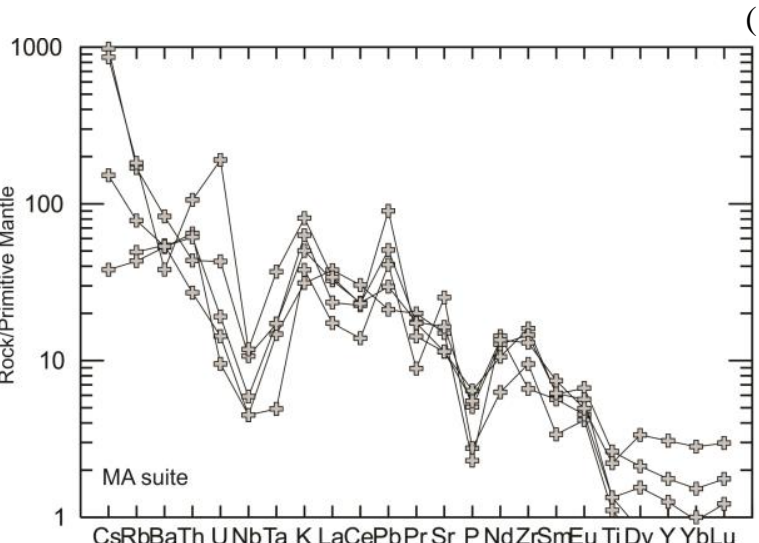
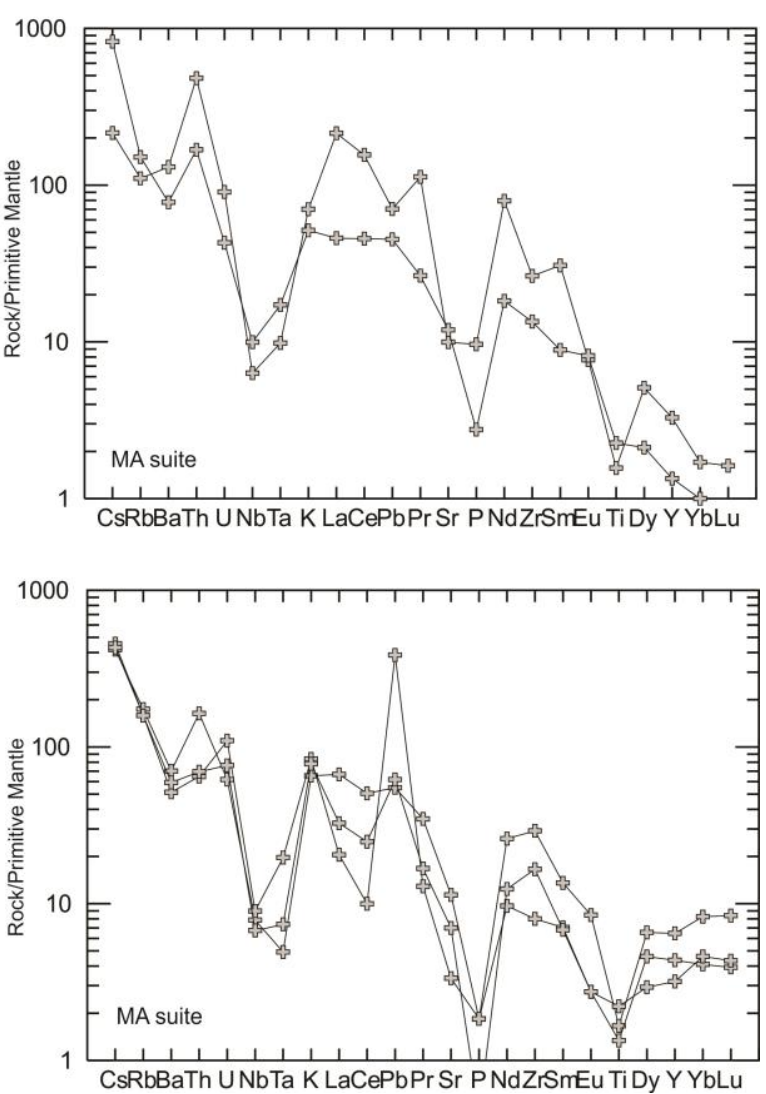

Figure 4.26: REE and multielementar spidergram of MA suite (Sun \& McDonough, 1989).
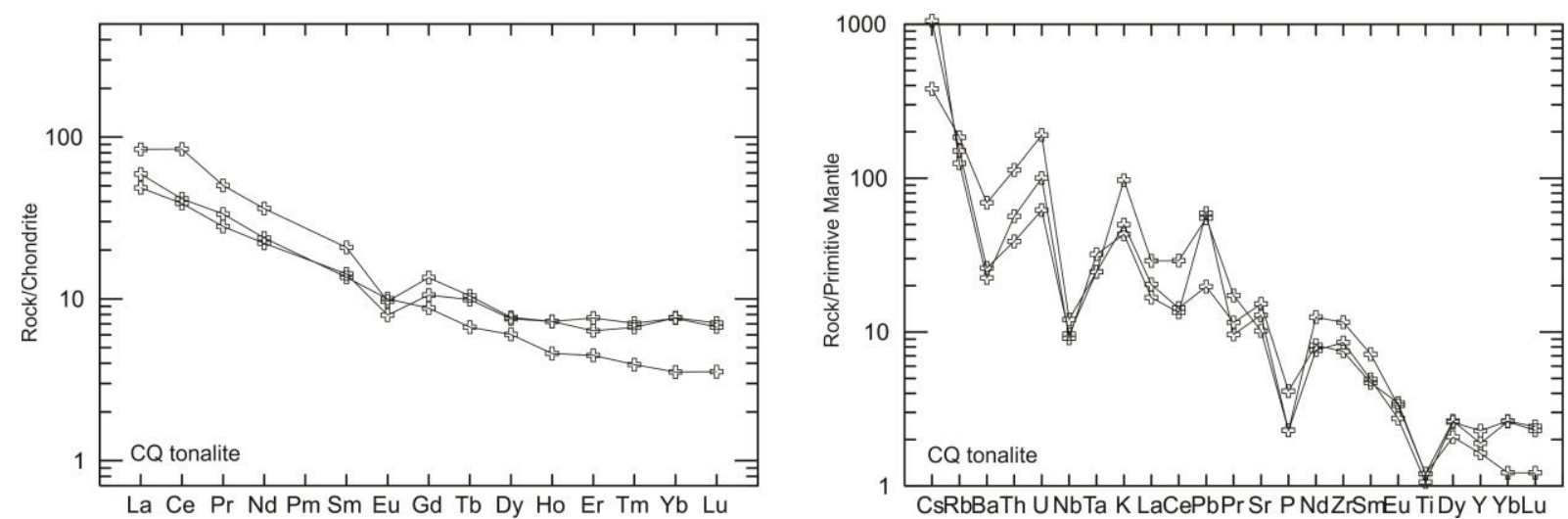
Figure 4.27). The dated sample, with $2185 \pm 6.5 \mathrm{Ma}$, is one of these. It is possible that crust became thicker as the arc evolved. Thus, magmas had a longer way to travel during ascent and fractional crystallization yielded more evolved end-members. The arc itself may have contributed to contamination in LILEs.

Within MA suite another two groups with distinct REE pattern exist, one behaves like RM suite, and the other has high LREE content, but a horizontal HREE pattern. The former may represent less evolved magmas and the latter can have a horizontal HREE pattern due to contamination with greywacke. Taylor \& McLennan (1981) suggest sediments that form greywacke are a mixture of mafic and felsic rocks, and represent the mean composition of the crust: high HREE from mafic rocks would mixture with felsic depleted samples in HREE and create a horizontal HREE alignment. MA samples with this characteristic are exactly the ones cropping out within the sedimentary sequence.

Finally, CQ tonalite, the younger unit without syn-collisional signature, dates at $2161 \pm 14$ Ma. Despite being younger, its REE pattern does not show enrichment in LREE, but shows HREE depletion. It can be interpreted as melting of mafic rocks, perhaps without crustal contamination. $\varepsilon_{\mathrm{Nd}}$ near zero indicates quick crystallization of a magma generated in the mantle.

Around $2.16 \mathrm{Ga}$, there is an important tectonic shift and magmatism assumed a different character. Convergence of landmasses yielded collision that triggered magmatism resultant from reworking of the crust. Thus, S1, S2, RM, MA and CQ could have been components of the landmasses that behaved as country rock for Aurumina suite, Xobó suite and Príncipe Granite.

We believe there is no distinction between Almas-Conceição do Tocantins domain and Natividade basement. They only represent different stages of magmatism in an evolving arc.

The Cruz das Almas Shear zone is probably coeval with the development of the magmatic arc. Today it is a vertical strike-slip structure, but it could have been a thrust fault developed during Paleoproterozoic orogeny.

Riachão do Ouro Group and Água Suja sequences could be termporally and spatially correlate units.

\subsection{Tectonic setting and proposed evolutional model}

Rhyacian magmatism shows three phases in the studied area: the first two have volcanic arc signature and the last one has syn-collisional signature (Pearce et al., 1984). 
Intuitively, one or more magmatic arc evolved from 2.30 to 2.16 , and by $2.15 \mathrm{Ga}$, the collision of landmasses produced the syn-collisional units.

The model, based on this premise, suggests an arc developed at the margin of the São Francisco craton. Siderian samples represent craton's youngest rocks in which the Rhyacian arc rocks intruded. The arc developed by convergence of a landmass towards São Francisco craton. What is this landmass is conjectural; it could even be the Archean core of Goiás Massif.

Rhyacian arc granitogenesis formed S1, S2 and RM at the same time it became a mature arc. MA suite and CQ tonalite intruded a more evolved crust. Cruz (2001) reports there was a $2.18 \mathrm{Ga}$ thermal event that provoked $\mathrm{Pb}$ loss in $\mathrm{S} 1$ and $\mathrm{S} 2$. MA suite intrusion could be responsible for this thermal event. Magmatism became more heterogeneous as the crust evolved. We suggest gathering all arc units as Conceição do Tocantins suite (Figure 4.36).

Lastly, around 2.15, a sialic core collided against what is now the São Francisco craton, generating the peraluminous magmatism, with negative $\varepsilon_{\mathrm{Nd}}$ of Aurumina suite, Xobó Suite and Príncipe Granite. 

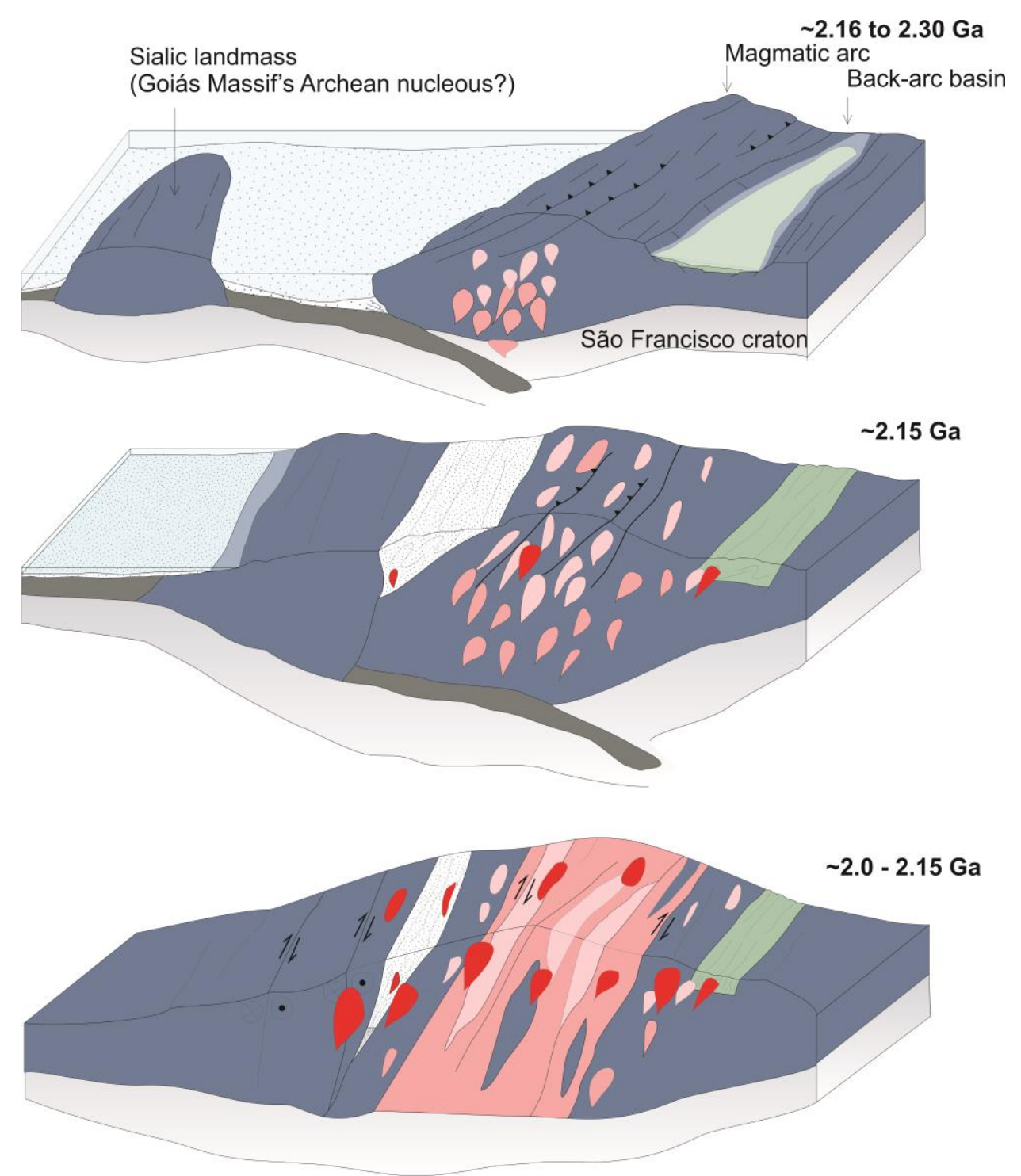

$<2.16 \mathrm{Ga}$ syn-collisional granites (Aurumina suite)

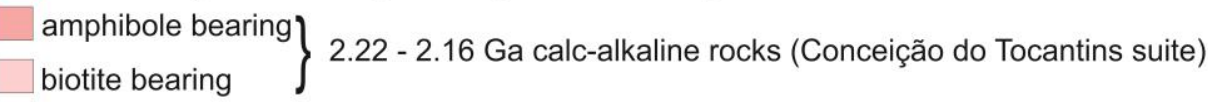

$\therefore>2.2$ Ga volcano-sedimentary sequences

$>2.3 \mathrm{Ga}$ rocks (TTG + greenstone?)

Figure 4.35: Proposed tectonic evolution of Brasília Belt basement.

This model is based on the existence of Siderian rocks among the Rhyacian calcalkaline rocks and on the existence of syn-collisional granites intrusive in the arc rocks. But other models could also apply. It is possible to imagine the calc-alkaline arc developed on a sialic microplate and the collisional granites are the result of its collision against São Francisco craton. 


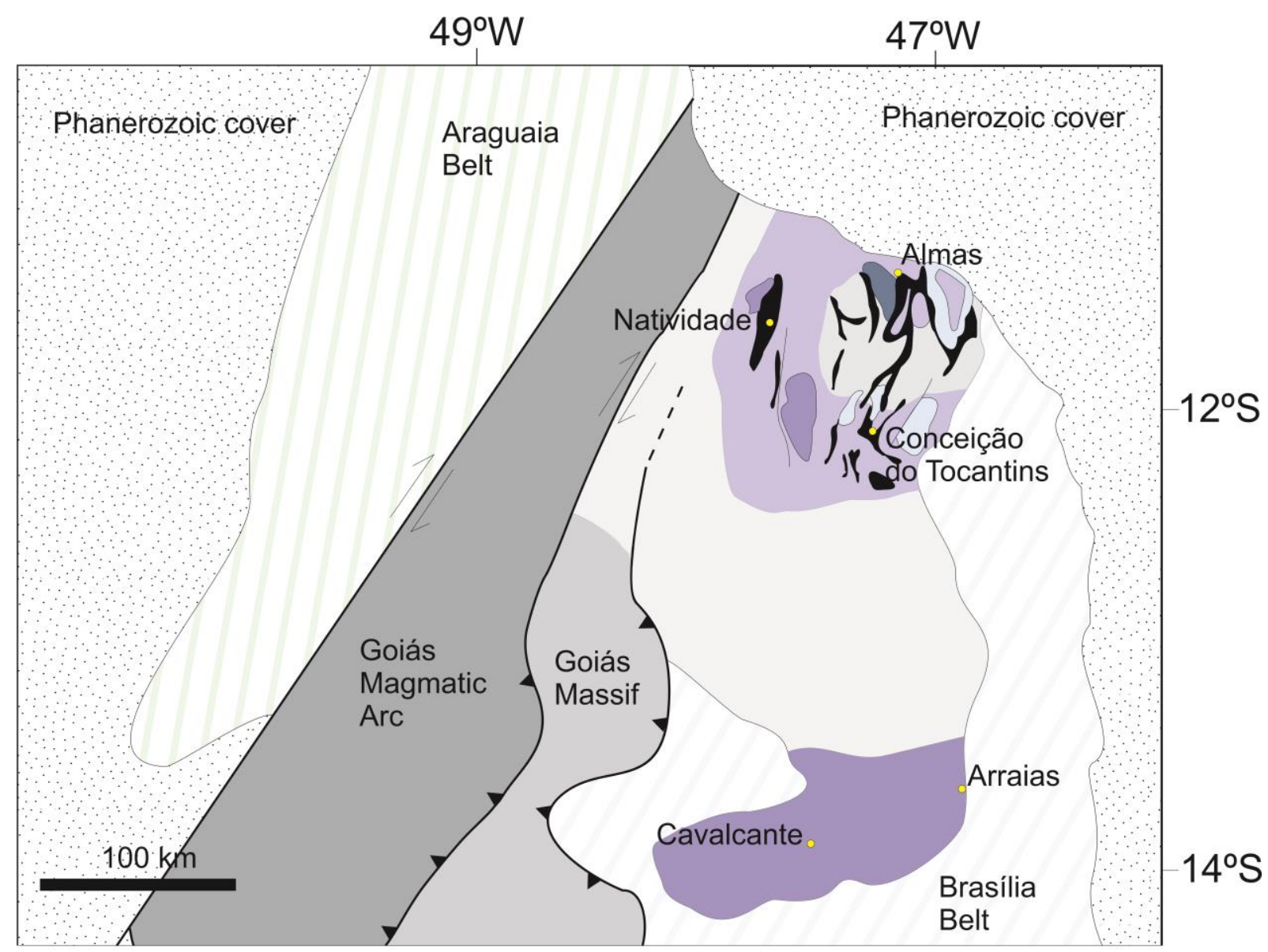

Aurumina suite $<2.15 \mathrm{Ga}$

Conceição do Tocantins suite (facies with biotite), 2.22 - $2.16 \mathrm{Ga}$

Conceição do Tocantins suite (facies with amphibole), $2.22 \mathrm{Ga}$

$>2.3 \mathrm{Ga}$ basement

Undifferentiated granitic rocks

$\uparrow$ Volcano-sedimentary sequences

Figure 4.36: Schematic representation of Paleoproterozoic rocks distribution in Brasília Belt basement. >2.3 area is the Ribeirão das Areias Complex.

\subsection{Implications on Regional Geology}

Regardless of considering the basement in northern Brasília Belt as an arc agglutinated to the São Francisco craton margin or developed in it during Rhyacian, we believe since then it is part of the craton. 
In this region, sedimentary cover lies over the basement - Bambuí, Natividade and Araí groups. Analogously, further south, sediments from the belt cover the basement. Thus, Paleoproterozoic outcrops in the belt are the basement exposure within younger sediments. Thereby, small Paleoproterozoic windows can represent magmatism of the same Rhyacian orogeny observed in northern Brasília belt. Campinorte sequence and its associate intrusive unit, Pau de Mel suite are Rhyancia and crop out within Goiás Massif

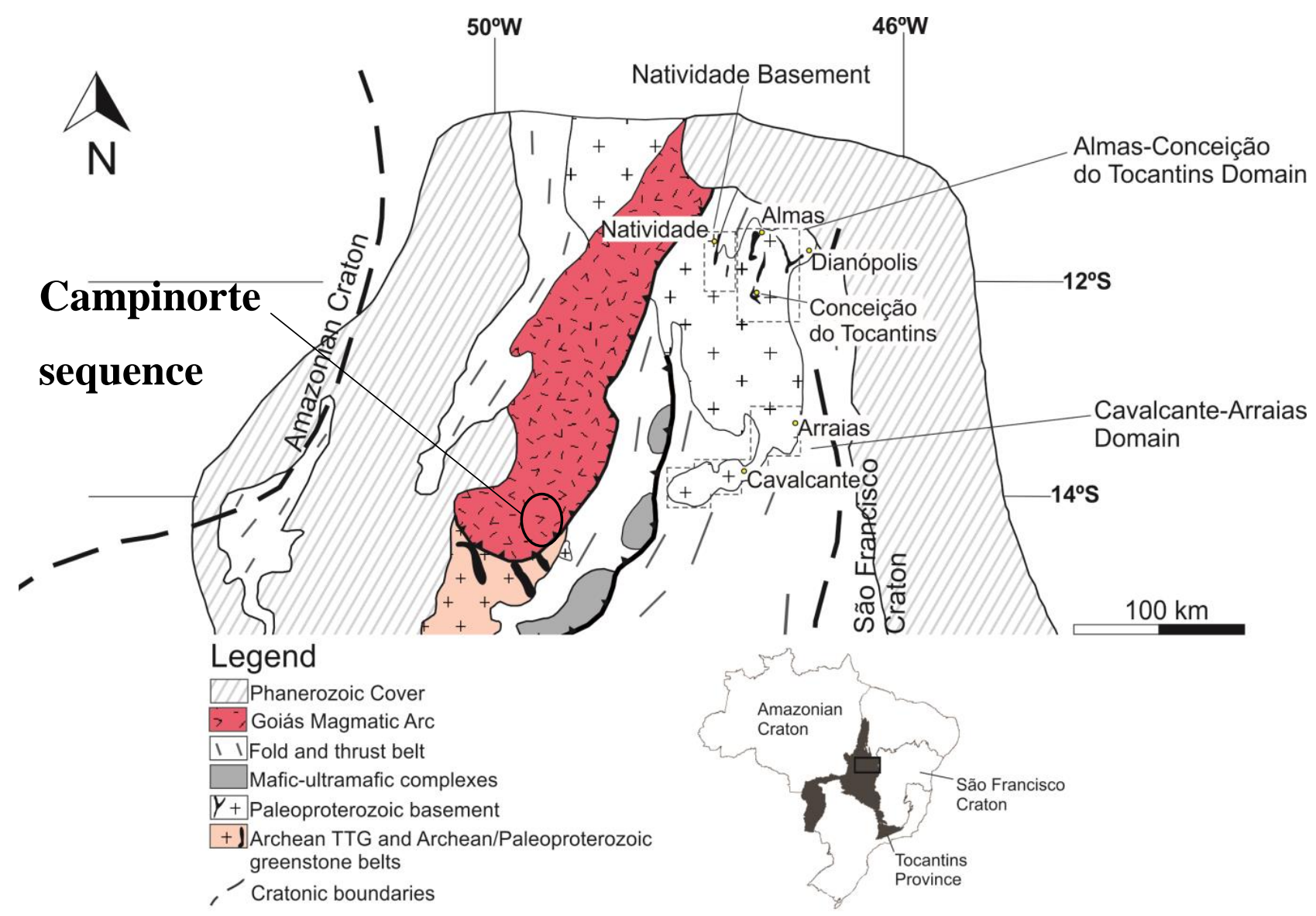

Figure 4.37: Campinorte sequence outcrop in Brasília Belt (Modified from Pimentel et al., 2006; Oliveira et al., 2006).

Campinorte sequence similarity with pre-collisional rocks studied in this paper is notable (Figure 4.38 and Figure 4.39). This can be an evidence that the Goiás Massif in not alloctonous, since its basement is very to Brasília Belt basement. 

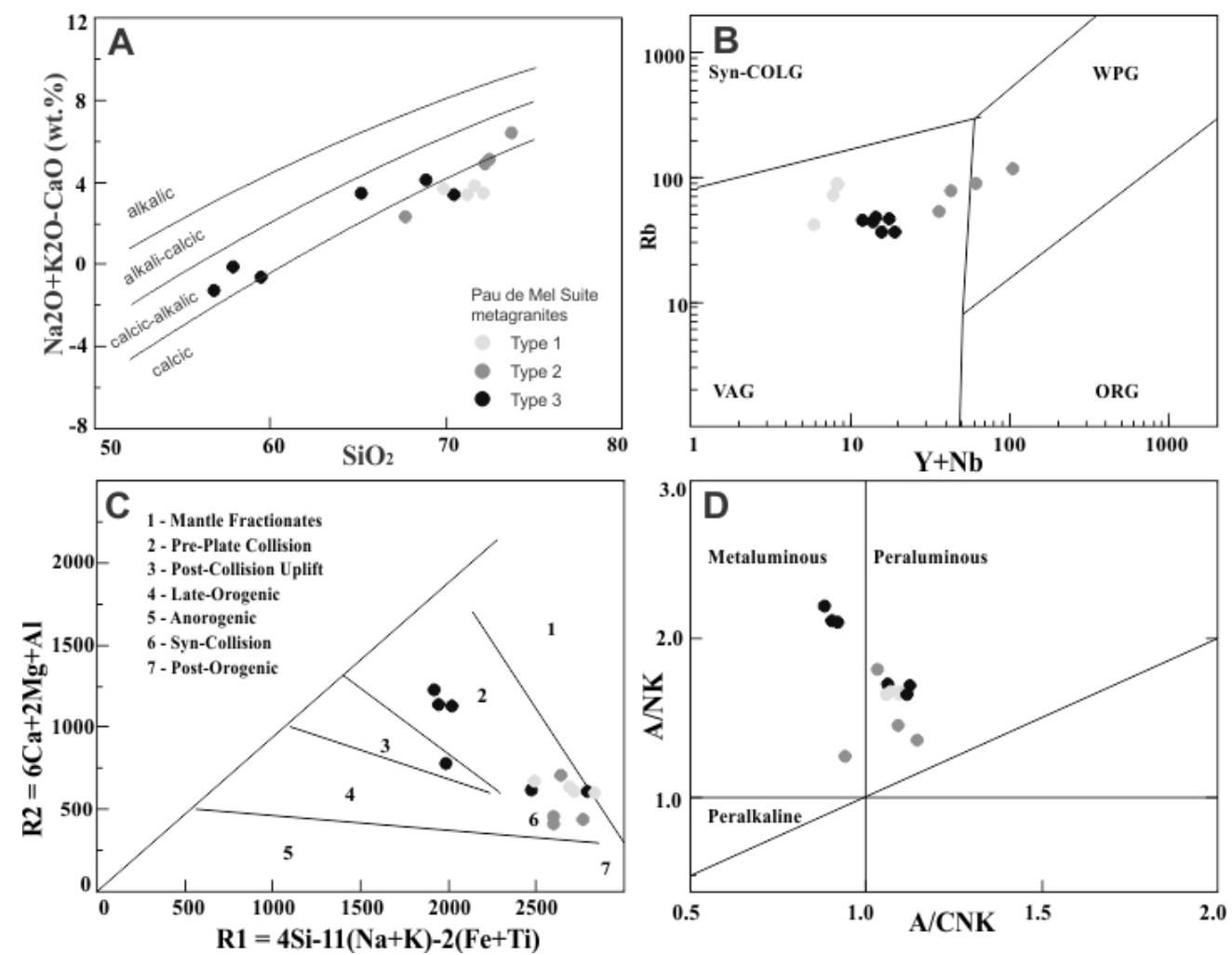

Figure 4.38: Chemistry data from Campinorte sequence (Cordeiro, 2014). A) $\mathrm{SiO}_{2}$ versus $\mathrm{K}_{2} \mathrm{O}+\mathrm{Na} 2 \mathrm{O}-\mathrm{CaO}$ plot from Frost et al. (2001); B) Rb versus $\mathrm{Y}+\mathrm{Nb}$ plot of Pearce et al. (1984); C) R1-R2 cationic plot of Batchelor and Bowden (1985); D) A/NK versus A/CKN (Shand diagram) plot.

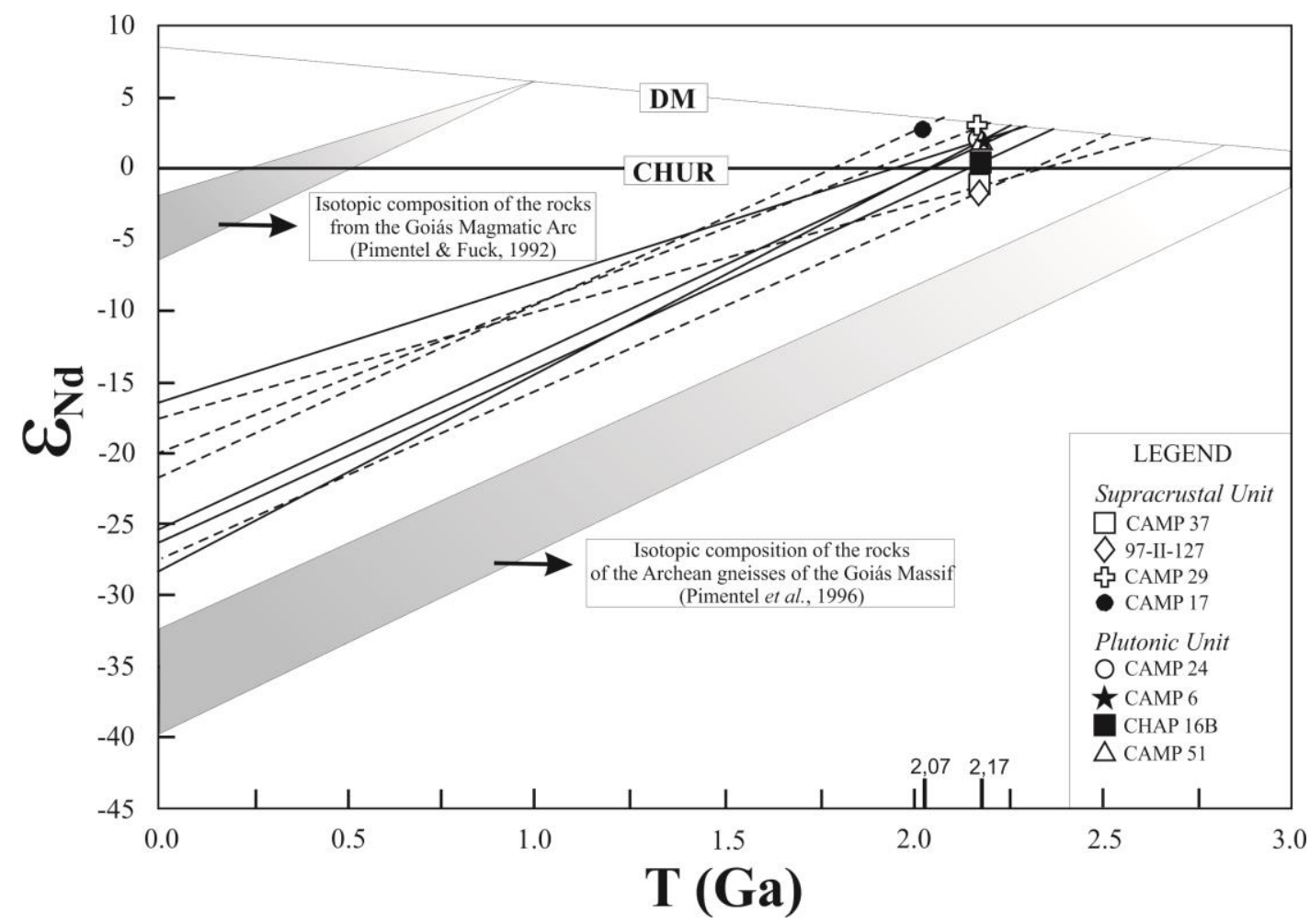

Figure 4.39: Nd isotopic evolution diagram comparing isotopic compositions of the Campinorte sequence and related intrusive rocks. Compositional fields of the Mara Rosa Magmatic Arc (Junges et al., 2003) and Goiás Archean Gneisses (Pimentel et al., 1996) are also shown (Della Giustina, 2007). 


\subsection{Conclusions}

Brasília belt basement is an ensemble of granitic rocks formed during multiple stages of magmatism from Siderian to Rhyacian. The basement represents a magmatic arc developed on the western margin of the São Francisco craton during late Rhyacian.

Volcanic arc rocks evolved in a calc-alkaline trend and form the pre-collisional assembly. Chemically, there is no reason to separate S1, S2, RM, MA and CQ in different suites, as they are almost the same age and belong to the same evolutional trend, seen in Harker and AFM diagrams. We propose to name the calc-alkaline series as Conceição do Tocantins suite, and divide it in two facies, an amphibole-bearing one ( $\mathrm{S} 1$ and probably Nova Roma quartz-diorite - Alvarenga et al., 2007) and a biotite bearing one (S2, RM, MA and CQ).

As Aurumina suite represents the collisional magmatism, XS and GP can be integrated to $\mathrm{Au} 2$ facies, the biotite-muscovite granite. Paleoproteozoic terrane between Almas and Dianópolis was traditionally interpreted as TTG, but when analysed together with new samples, they all have "ordinary" arc signature.

Cruz das Almas Shear Zone is big fault, but there is no chemical evidence that it corresponds to a suture zone or a tectonic boundary. Curiously, Siderian ages are still not described west of the fault. Absence of honeycomb greenstone belts surrounding tonalitic domes west of CASZ is justifiable by greater shearing influenced by Transbrasiliano structures. Shear obliterated and compressed structures with that configuration. Difference in geophysical signal east and west of CASZ is attributed to the quantity of greenstone belts cropping out among igneous bodies.

Riachão do Ouro Group and Água Suja sequence are correlate units, probably formed in a back-arc environment and should be united through the nomenclature Riachão do Ouro Group. We should not discard the hypothesis that these rocks are older than Rhyacian.

Detailed cartography of the area and geochronology of volcano-sedimentary sequences are still necessary. Future studies should focus the uncartographed area between Cavalcante-Arraias and Almas-Conceição do Tocantins domains.

Further research of Silvânia and Campinorte sequences and associate intrusive units may provide data to compare them with Conceição do Tocantins suite. Isotope geochemistry of greenstone belts from Goiás Massif, Riachão do Ouro Group and Ticunzal Formation is fundamental to verify if it is possible that all these sequences were deposited in the same basin. 
Complete knowledge of Paleoproterozoic is unachievable, but thorough geochemistry and geochronology are the main tools to understand this remote Era of Earth's History. 


\subsection{Appendix}

Table 4.2: Summary of ICP-MS U-Pb zircon data.

\begin{tabular}{|c|c|c|c|c|c|c|c|c|c|c|c|c|c|c|c|c|c|}
\hline Sample & $\mathrm{f}(206) \%$ & $\mathrm{Th} / \mathrm{U}$ & $6 / 4$ ratio & $7 / 6$ ratio & $1 \mathrm{~s}(\%)$ & $7 / 5$ ratio & $1 \mathrm{~s}(\%)$ & $6 / 8$ ratio & $1 \mathrm{~s}(\%)$ & Rho & $7 / 6$ age & $1 \mathrm{~s}(\mathrm{Ma})$ & $7 / 5$ age & $1 \mathrm{~s}(\mathrm{Ma})$ & $6 / 8$ age & $1 \mathrm{~s}(\mathrm{Ma})$ & Conc $(\%)$ \\
\hline \multicolumn{18}{|c|}{ Sample G3 } \\
\hline 004-Z01 & 0.85 & 0.44 & 1102.86 & 0.15 & 1.2 & 6.56 & 2.7 & 0.33 & 2.5 & 0.90 & 2288.9 & 20.3 & 2054.5 & 24.2 & 1829.2 & 39.5 & 79.92 \\
\hline 010-Z05 & 0.16 & 0.66 & 20999.98 & 0.14 & 0.5 & 4.86 & 2.1 & 0.26 & 2.0 & 0.97 & 2183.1 & 8.8 & 1795.5 & 17.7 & 1481.1 & 27.1 & 67.84 \\
\hline 015-Z08 & 0.76 & 0.33 & 2054.42 & 0.14 & 0.8 & 6.31 & 1.7 & 0.32 & 1.4 & 0.87 & 2246.2 & 14.1 & 2020.3 & 14.6 & 1806.8 & 22.8 & 80.44 \\
\hline 022-Z13 & 0.61 & 0.33 & 1780.36 & 0.14 & 0.5 & 6.03 & 1.5 & 0.31 & 1.4 & 0.94 & 2231.3 & 9.1 & 1979.7 & 13.4 & 1747.9 & 22.1 & 78.34 \\
\hline 024-Z15 & 0.13 & 0.23 & 11815.39 & 0.15 & 1.0 & 8.22 & 3.4 & 0.39 & 3.2 & 0.98 & 2379.1 & 17.3 & 2255.7 & 30.7 & 2122.1 & 58.5 & 89.20 \\
\hline 027-Z16 & 0.31 & 0.41 & 5083.21 & 0.14 & 0.7 & 5.54 & 2.0 & 0.30 & 1.9 & 0.94 & 2174.8 & 11.7 & 1907.5 & 17.2 & 1671.6 & 27.6 & 76.86 \\
\hline 028-Z17 & 0.13 & 0.34 & 23728.70 & 0.14 & 0.6 & 6.21 & 2.2 & 0.31 & 2.1 & 0.96 & 2271.5 & 10.0 & 2005.8 & 18.9 & 1758.1 & 32.1 & 77.40 \\
\hline 029-Z18 & 0.04 & 0.52 & 33586.18 & 0.15 & 0.6 & 8.00 & 2.0 & 0.38 & 1.9 & 0.96 & 2386.9 & 9.8 & 2230.6 & 17.8 & 2064.4 & 33.3 & 86.49 \\
\hline 034-Z21 & 0.32 & 0.51 & 10303.90 & 0.14 & 0.6 & 5.94 & 1.8 & 0.30 & 1.7 & 0.94 & 2248.1 & 10.2 & 1967.5 & 15.7 & 1711.9 & 25.7 & 76.15 \\
\hline 035-Z22 & 0.92 & 0.39 & 1631.93 & 0.15 & 1.3 & 8.10 & 3.8 & 0.38 & 3.5 & 0.94 & 2390.8 & 21.6 & 2241.9 & 34.0 & 2082.6 & 63.0 & 87.11 \\
\hline $045-Z 27$ & 0.45 & 0.41 & 3401.08 & 0.14 & 0.7 & 7.09 & 2.4 & 0.36 & 2.3 & 0.95 & 2280.0 & 12.8 & 2122.9 & 21.3 & 1964.5 & 38.6 & 86.16 \\
\hline 046-Z28 & 0.18 & 0.61 & 22616.43 & 0.15 & 0.8 & 7.50 & 2.1 & 0.37 & 1.9 & 0.93 & 2329.7 & 13.4 & 2173.3 & 18.8 & 2011.6 & 33.6 & 86.35 \\
\hline Sample & $f(206) \%$ & $\mathrm{Th} / \mathrm{U}$ & $6 / 4$ ratio & $7 / 6$ ratio & $1 \mathrm{~s}(\%)$ & $7 / 5$ ratio & $1 \mathrm{~s}(\%)$ & $6 / 8$ ratio & $1 \mathrm{~s}(\%)$ & Rho & 7/6 age & $1 \mathrm{~s}(\mathrm{Ma})$ & $7 / 5$ age & $1 \mathrm{~s}(\mathrm{Ma})$ & $6 / 8$ age & $1 \mathrm{~s}(\mathrm{Ma})$ & Conc $(\%)$ \\
\hline \multicolumn{18}{|c|}{ Sample PI-4I } \\
\hline 004-Z1 & 0.15 & 0.34 & 10300.02 & 0.14 & 0.5 & 7.54 & 0.9 & 0.38 & 0.8 & 0.84 & 2268.3 & 7.8 & 2177.2 & 8.0 & 2081.8 & 13.71 & 91.78 \\
\hline 009-Z3 & 0.01 & 0.38 & 158131.81 & 0.14 & 0.5 & 8.08 & 0.8 & 0.41 & 0.6 & 0.70 & 2270.9 & 9.0 & 2239.7 & 7.1 & 2205.8 & 11.08 & 97.14 \\
\hline 010-Z4 & 0.02 & 0.40 & 78623.86 & 0.14 & 0.5 & 8.22 & 0.9 & 0.41 & 0.7 & 0.78 & 2271.7 & 9.0 & 2255.2 & 8.1 & 2237.1 & 13.71 & 98.47 \\
\hline $012-\mathrm{Z} 6 \mathrm{~N}$ & 0.01 & 0.30 & 234685.24 & 0.14 & 0.5 & 8.40 & 0.9 & 0.43 & 0.7 & 0.82 & 2256.8 & 7.9 & 2275.5 & 7.7 & 2296.4 & 13.84 & 101.76 \\
\hline 015-Z6B & 0.01 & 0.31 & 289995.81 & 0.14 & 0.5 & 7.89 & 0.8 & 0.40 & 0.6 & 0.69 & 2257.6 & 9.2 & 2218.4 & 7.2 & 2176.1 & 11.03 & 96.39 \\
\hline 022-Z11 & 0.01 & 0.41 & 160513.05 & 0.14 & 0.6 & 8.12 & 0.9 & 0.41 & 0.8 & 0.78 & 2256.7 & 9.6 & 2244.3 & 8.6 & 2230.8 & 14.43 & 98.86 \\
\hline 023-Z12 & 0.03 & 0.35 & 56493.92 & 0.14 & 0.3 & 7.90 & 0.7 & 0.40 & 0.6 & 0.83 & 2274.1 & 5.8 & 2219.9 & 6.1 & 2161.7 & 10.81 & 95.06 \\
\hline 024-Z13 & 0.01 & 0.22 & 218928.90 & 0.14 & 0.4 & 7.57 & 1.1 & 0.38 & 1.0 & 0.93 & 2270.0 & 6.3 & 2181.6 & 9.5 & 2088.8 & 17.68 & 92.02 \\
\hline 039-Z21 & 0.01 & 0.43 & 194635.82 & 0.14 & 0.4 & 7.17 & 1.1 & 0.37 & 1.0 & 0.91 & 2253.7 & 7.4 & 2132.9 & 9.5 & 2009.7 & 16.96 & 89.17 \\
\hline 041-Z23 & 0.01 & 0.58 & 189925.15 & 0.14 & 0.4 & 7.74 & 0.9 & 0.39 & 0.8 & 0.88 & 2268.4 & 6.6 & 2201.6 & 7.7 & 2130.6 & 13.90 & 93.93 \\
\hline
\end{tabular}


4. Evolução crustal riaciana do embasamento paleoproterozóico da Faixa Brasília

\begin{tabular}{|c|c|c|c|c|c|c|c|c|c|c|c|c|c|c|c|c|c|}
\hline $045-Z 25$ & 0.23 & 0.48 & 7019.64 & 0.14 & 0.5 & 5.51 & 1.4 & 0.28 & 1.4 & 0.94 & 2251.7 & 8.2 & 1902.5 & 12.4 & 1599.1 & 19.25 & 71.02 \\
\hline 047-Z27 & 1.03 & 0.33 & 1606.47 & 0.14 & 1.1 & 4.37 & 1.7 & 0.22 & 1.3 & 0.77 & 2268.7 & 18.8 & 1706.2 & 14.0 & 1286.6 & 15.25 & 56.71 \\
\hline 048-Z28 & 0.01 & 0.50 & 140404.30 & 0.14 & 0.5 & 7.73 & 0.9 & 0.39 & 0.8 & 0.81 & 2260.3 & 8.6 & 2200.1 & 8.1 & 2136.1 & 13.68 & 94.50 \\
\hline 052-Z30 & 0.01 & 0.27 & 192103.14 & 0.15 & 0.3 & 8.33 & 0.7 & 0.42 & 0.6 & 0.86 & 2295.2 & 5.5 & 2267.9 & 6.3 & 2237.9 & 11.58 & 97.50 \\
\hline 054-Z32 & 0.00 & 0.18 & 811540.11 & 0.14 & 0.3 & 7.59 & 0.7 & 0.39 & 0.6 & 0.84 & 2247.0 & 5.8 & 2183.7 & 6.2 & 2117.0 & 10.94 & 94.21 \\
\hline Sample & $f(206) \%$ & $\mathrm{Th} / \mathrm{U}$ & $6 / 4$ ratio & $7 / 6$ ratio & $1 \mathrm{~s}(\%)$ & $7 / 5$ ratio & $1 \mathrm{~s}(\%)$ & $6 / 8$ ratio & $1 \mathrm{~s}(\%)$ & Rho & $7 / 6$ age & $1 \mathrm{~s}(\mathrm{Ma})$ & $7 / 5$ age & $1 \mathrm{~s}(\mathrm{Ma})$ & $6 / 8$ age & 1s(Ma) & Conc $(\%)$ \\
\hline \multicolumn{18}{|c|}{ Sample NI-VIII-122 } \\
\hline 003-Z1 & 0.45 & 0.27 & 3313.13 & 0.13 & 0.3 & 7.11 & 0.8 & 0.38 & 0.7 & 0.88 & 2162.9 & 5.8 & 2125.2 & 6.9 & 2086.5 & 12.56 & 96.47 \\
\hline 004-Z2 & 0.41 & 0.38 & 3691.99 & 0.13 & 0.3 & 6.44 & 0.8 & 0.35 & 0.7 & 0.91 & 2153.1 & 5.1 & 2037.2 & 6.7 & 1924.7 & 11.69 & 89.39 \\
\hline 008-Z6 & 0.31 & 0.14 & 4857.87 & 0.14 & 0.3 & 7.38 & 0.6 & 0.39 & 0.6 & 0.86 & 2189.1 & 4.9 & 2158.5 & 5.7 & 2126.4 & 10.35 & 97.13 \\
\hline 010-Z8 & 0.07 & 0.57 & 19279.72 & 0.14 & 0.8 & 8.90 & 1.0 & 0.45 & 0.7 & 0.82 & 2277.4 & 13.0 & 2327.9 & 9.3 & 2385.9 & 13.71 & 104.77 \\
\hline 017-Z12 & 0.24 & 0.24 & 6053.60 & 0.14 & 0.3 & 8.38 & 0.8 & 0.43 & 0.7 & 0.89 & 2249.5 & 5.4 & 2272.8 & 6.9 & 2298.8 & 13.49 & 102.19 \\
\hline 018-Z13C & 0.46 & 0.53 & 3128.04 & 0.14 & 0.3 & 8.78 & 1.0 & 0.44 & 0.9 & 0.93 & 2274.9 & 5.9 & 2315.4 & 8.9 & 2361.5 & 18.09 & 103.81 \\
\hline 019-Z13B & 0.12 & 0.23 & 12274.19 & 0.14 & 0.3 & 8.92 & 0.7 & 0.45 & 0.6 & 0.87 & 2266.0 & 5.4 & 2330.3 & 6.4 & 2404.6 & 12.51 & 106.12 \\
\hline 020-Z14 & 0.07 & 0.23 & 19482.14 & 0.14 & 0.6 & 8.84 & 0.8 & 0.44 & 0.5 & 0.76 & 2286.6 & 9.8 & 2321.5 & 7.2 & 2361.5 & 10.70 & 103.28 \\
\hline 024-Z16 & 0.37 & 0.22 & 3973.30 & 0.14 & 0.5 & 7.58 & 0.8 & 0.40 & 0.6 & 0.76 & 2213.0 & 8.3 & 2182.5 & 7.2 & 2150.3 & 11.79 & 97.17 \\
\hline 027-Z19 & 0.77 & 0.26 & 1950.92 & 0.13 & 0.4 & 7.04 & 0.8 & 0.38 & 0.7 & 0.86 & 2163.5 & 6.3 & 2117.0 & 6.8 & 2069.5 & 11.98 & 95.65 \\
\hline 028-Z20 & 0.25 & 0.36 & 5902.69 & 0.14 & 0.5 & 7.67 & 1.5 & 0.40 & 1.4 & 0.95 & 2223.0 & 8.2 & 2193.3 & 13.7 & 2161.6 & 26.57 & 97.24 \\
\hline 029-Z21 & 0.42 & 0.47 & 3668.39 & 0.13 & 0.3 & 5.96 & 1.4 & 0.33 & 1.4 & 0.98 & 2128.3 & 4.7 & 1970.6 & 12.3 & 1823.9 & 22.21 & 85.70 \\
\hline 030-Z22 & 0.29 & 0.28 & 5333.54 & 0.14 & 1.0 & 6.73 & 1.4 & 0.36 & 1.0 & 0.87 & 2189.5 & 17.5 & 2077.0 & 12.6 & 1965.5 & 17.02 & 89.77 \\
\hline 034-Z24 & 0.37 & 0.37 & 4089.72 & 0.13 & 0.4 & 6.38 & 1.4 & 0.35 & 1.3 & 0.96 & 2136.6 & 6.6 & 2029.6 & 12.0 & 1926.0 & 21.93 & 90.14 \\
\hline 038-Z28 & 0.51 & 0.34 & 2992.02 & 0.13 & 0.5 & 6.42 & 1.1 & 0.35 & 1.0 & 0.90 & 2137.3 & 7.9 & 2035.6 & 9.4 & 1936.8 & 16.28 & 90.62 \\
\hline 047-Z35 & 1.44 & 0.74 & 1138.31 & 0.12 & 0.9 & 3.75 & 1.7 & 0.24 & 1.4 & 0.85 & 1888.7 & 15.6 & 1582.0 & 13.5 & 1362.2 & 17.84 & 72.13 \\
\hline Sample & $f(206) \%$ & $\mathrm{Th} / \mathrm{U}$ & $6 / 4$ ratio & $7 / 6$ ratio & $1 \mathrm{~s}(\%)$ & $7 / 5$ ratio & $1 \mathrm{~s}(\%)$ & $6 / 8$ ratio & $1 \mathrm{~s}(\%)$ & Rho & $7 / 6$ age & $1 \mathrm{~s}(\mathrm{Ma})$ & $7 / 5$ age & $1 \mathrm{~s}(\mathrm{Ma})$ & $6 / 8$ age & $1 \mathrm{~s}(\mathrm{Ma})$ & Conc $(\%)$ \\
\hline \multicolumn{18}{|c|}{ Sample NI-V-24B } \\
\hline 003-Z1 & 0.21 & 0.24 & 6943.51 & 0.14 & 0.3 & 7.56 & 0.5 & 0.40 & 0.5 & 0.76 & 2180.4 & 4.9 & 2180.1 & 4.8 & 2179.9 & 8.45 & 99.98 \\
\hline 004-Z2C & 0.26 & 0.20 & 5810.06 & 0.14 & 0.3 & 7.28 & 0.7 & 0.39 & 0.6 & 0.82 & 2177.5 & 6.0 & 2146.5 & 6.1 & 2114.1 & 10.57 & 97.09 \\
\hline 005-Z2B & 0.05 & 0.16 & 28313.01 & 0.13 & 0.3 & 7.14 & 0.9 & 0.39 & 0.9 & 0.94 & 2155.8 & 5.2 & 2129.6 & 8.5 & 2102.5 & 16.16 & 97.53 \\
\hline 006-Z3 & 0.01 & 0.25 & 112326.42 & 0.14 & 0.4 & 7.60 & 0.7 & 0.40 & 0.6 & 0.86 & 2204.3 & 6.9 & 2185.2 & 6.2 & 2165.0 & 10.35 & 98.21 \\
\hline 007-Z4 & 0.00 & 0.09 & 370746.22 & 0.14 & 0.3 & 7.54 & 0.6 & 0.40 & 0.5 & 0.85 & 2200.2 & 4.8 & 2178.0 & 5.5 & 2154.5 & 9.92 & 97.92 \\
\hline
\end{tabular}


4. Evolução crustal riaciana do embasamento paleoproterozóico da Faixa Brasília

\begin{tabular}{|c|c|c|c|c|c|c|c|c|c|c|c|c|c|c|c|c|c|}
\hline 008-Z5 & 0.01 & 0.19 & 287059.67 & 0.14 & 0.2 & 7.29 & 0.5 & 0.39 & 0.5 & 0.84 & 2183.3 & 4.2 & 2147.7 & 4.8 & 2110.7 & 8.71 & 96.67 \\
\hline 013-Z8C & 0.02 & 0.61 & 89320.82 & 0.14 & 0.6 & 7.73 & 1.0 & 0.41 & 0.8 & 0.79 & 2179.7 & 9.6 & 2200.7 & 8.6 & 2223.2 & 14.59 & 101.99 \\
\hline 014-Z8B & 0.05 & 0.06 & 31182.39 & 0.13 & 0.3 & 7.09 & 0.6 & 0.38 & 0.5 & 0.80 & 2154.4 & 5.2 & 2122.6 & 5.2 & 2089.9 & 8.88 & 97.01 \\
\hline 015-Z9 & 0.16 & 0.42 & 8961.22 & 0.14 & 0.3 & 7.58 & 0.6 & 0.40 & 0.5 & 0.81 & 2185.4 & 5.0 & 2182.8 & 5.2 & 2180.1 & 9.35 & 99.76 \\
\hline 017-Z11 & 0.01 & 0.07 & 155165.88 & 0.14 & 0.3 & 7.74 & 0.6 & 0.41 & 0.5 & 0.83 & 2181.2 & 4.9 & 2201.7 & 5.4 & 2223.8 & 9.85 & 101.95 \\
\hline 018-Z12 & 0.00 & 0.26 & 360039.68 & 0.14 & 0.3 & 7.74 & 0.6 & 0.41 & 0.5 & 0.81 & 2204.0 & 4.9 & 2201.5 & 5.1 & 2198.9 & 9.18 & 99.77 \\
\hline 019-Z13C & 0.01 & 0.35 & 186064.84 & 0.14 & 0.5 & 7.70 & 0.8 & 0.40 & 0.6 & 0.75 & 2220.3 & 8.0 & 2197.0 & 6.8 & 2172.2 & 11.14 & 97.84 \\
\hline 020-Z13B & 0.05 & 0.03 & 32937.61 & 0.14 & 0.5 & 6.89 & 0.8 & 0.37 & 0.6 & 0.79 & 2164.5 & 9.1 & 2097.6 & 6.7 & 2030.2 & 9.64 & 93.80 \\
\hline 023-Z14 & 0.01 & 0.30 & 120321.83 & 0.14 & 0.4 & 7.62 & 0.6 & 0.40 & 0.5 & 0.76 & 2215.0 & 6.3 & 2187.1 & 5.7 & 2157.5 & 9.62 & 97.40 \\
\hline 024-Z15 & 0.00 & 0.15 & 700871.89 & 0.14 & 0.3 & 7.68 & 0.6 & 0.40 & 0.5 & 0.79 & 2216.7 & 5.4 & 2194.4 & 5.4 & 2170.7 & 9.48 & 97.92 \\
\hline 025-Z16 & 0.01 & 0.19 & 124887.96 & 0.14 & 0.4 & 7.61 & 0.8 & 0.40 & 0.7 & 0.82 & 2201.2 & 6.9 & 2185.6 & 6.9 & 2169.0 & 12.07 & 98.54 \\
\hline 026-Z17 & 0.02 & 0.14 & 79837.52 & 0.14 & 0.5 & 7.75 & 0.8 & 0.41 & 0.6 & 0.85 & 2199.9 & 8.0 & 2202.4 & 6.8 & 2205.1 & 11.16 & 100.24 \\
\hline 027-Z18 & 0.02 & 0.08 & 108511.15 & 0.12 & 1.2 & 2.94 & 2.7 & 0.18 & 2.4 & 0.90 & 1943.3 & 20.6 & 1392.6 & 20.3 & 1061.8 & 23.74 & 54.64 \\
\hline 028-Z19 & 0.03 & 0.22 & 52067.51 & 0.14 & 0.4 & 7.31 & 1.0 & 0.38 & 1.0 & 0.92 & 2199.9 & 6.8 & 2149.9 & 9.3 & 2098.0 & 17.36 & 95.37 \\
\hline 029-Z20 & 0.00 & 0.24 & 546946.92 & 0.14 & 0.4 & 7.85 & 0.6 & 0.41 & 0.5 & 0.73 & 2220.0 & 6.2 & 2214.5 & 5.5 & 2208.7 & 9.16 & 99.49 \\
\hline 030-Z21 & 0.01 & 0.21 & 176443.67 & 0.14 & 0.4 & 7.66 & 0.6 & 0.40 & 0.5 & 0.74 & 2206.7 & 6.9 & 2191.4 & 5.6 & 2175.1 & 8.79 & 98.56 \\
\hline 033-Z22 & 0.00 & 0.11 & 470081.83 & 0.14 & 0.3 & 7.70 & 0.6 & 0.41 & 0.5 & 0.79 & 2189.2 & 5.8 & 2196.3 & 5.6 & 2204.0 & 9.91 & 100.68 \\
\hline $034-Z 23$ & 0.01 & 0.21 & 164967.99 & 0.14 & 0.4 & 7.93 & 0.9 & 0.41 & 0.8 & 0.86 & 2220.2 & 7.6 & 2223.0 & 8.1 & 2226.0 & 14.86 & 100.26 \\
\hline 035-Z24 & 0.01 & 0.25 & 137314.62 & 0.14 & 0.4 & 7.38 & 0.8 & 0.38 & 0.6 & 0.76 & 2217.4 & 7.7 & 2158.1 & 6.7 & 2096.4 & 10.86 & 94.55 \\
\hline 036-Z25 & 0.01 & 0.28 & 105799.31 & 0.14 & 0.4 & 7.72 & 0.7 & 0.41 & 0.6 & 0.86 & 2195.6 & 7.2 & 2199.0 & 6.4 & 2202.8 & 10.76 & 100.33 \\
\hline 037-Z26 & 0.01 & 0.28 & 177914.35 & 0.14 & 0.3 & 7.80 & 0.7 & 0.41 & 0.6 & 0.85 & 2189.6 & 5.8 & 2208.2 & 6.2 & 2228.2 & 11.48 & 101.76 \\
\hline 038-Z27 & 0.03 & 0.27 & 47812.00 & 0.14 & 0.3 & 7.74 & 0.6 & 0.41 & 0.5 & 0.82 & 2195.4 & 4.8 & 2201.6 & 5.2 & 2208.2 & 9.47 & 100.58 \\
\hline 039-Z28 & 0.02 & 0.27 & 97598.16 & 0.14 & 0.3 & 7.56 & 0.6 & 0.39 & 0.5 & 0.83 & 2213.4 & 5.1 & 2180.1 & 5.4 & 2144.9 & 9.68 & 96.91 \\
\hline 040-Z29 & 0.00 & 0.15 & 637331.59 & 0.14 & 0.4 & 7.71 & 0.7 & 0.40 & 0.6 & 0.88 & 2237.5 & 6.5 & 2197.8 & 6.3 & 2155.5 & 10.77 & 96.34 \\
\hline 043-Z30 & 0.22 & 0.31 & 6784.13 & 0.14 & 0.3 & 7.64 & 1.3 & 0.40 & 1.2 & 0.96 & 2208.6 & 6.0 & 2190.0 & 11.3 & 2170.3 & 22.19 & 98.27 \\
\hline 044-Z31 & 0.02 & 0.27 & 74726.89 & 0.14 & 0.3 & 7.63 & 0.6 & 0.40 & 0.5 & 0.77 & 2211.5 & 5.9 & 2188.6 & 5.6 & 2164.2 & 9.51 & 97.86 \\
\hline 045-Z32 & 0.00 & 0.29 & 388268.12 & 0.14 & 0.3 & 7.55 & 0.6 & 0.39 & 0.5 & 0.74 & 2223.7 & 6.0 & 2179.1 & 5.4 & 2132.0 & 9.00 & 95.88 \\
\hline 046-Z33 & 0.01 & 0.30 & 110477.99 & 0.14 & 0.6 & 7.49 & 0.8 & 0.39 & 0.6 & 0.79 & 2216.9 & 10.8 & 2172.3 & 7.5 & 2125.4 & 10.15 & 95.87 \\
\hline 047-Z34 & 0.06 & 0.24 & 25882.48 & 0.14 & 0.5 & 7.50 & 0.8 & 0.40 & 0.6 & 0.73 & 2184.6 & 9.1 & 2172.6 & 7.4 & 2159.8 & 11.80 & 98.87 \\
\hline $048-Z 25$ & 0.10 & 0.22 & 15573.29 & 0.14 & 0.5 & 7.37 & 0.9 & 0.39 & 0.7 & 0.80 & 2181.2 & 8.6 & 2156.9 & 7.8 & 2131.4 & 13.09 & 97.71 \\
\hline 049-Z36 & 0.10 & 0.24 & 15407.50 & 0.14 & 0.3 & 7.53 & 0.6 & 0.40 & 0.6 & 0.82 & 2183.3 & 5.6 & 2176.1 & 5.7 & 2168.5 & 10.18 & 99.32 \\
\hline 050-Z37 & 0.01 & 0.22 & 216476.41 & 0.14 & 0.4 & 7.56 & 0.7 & 0.40 & 0.6 & 0.88 & 2207.0 & 6.7 & 2180.5 & 6.4 & 2152.3 & 10.92 & 97.52 \\
\hline
\end{tabular}




\begin{tabular}{|c|c|c|c|c|c|c|c|c|c|c|c|c|c|c|c|c|c|}
\hline Sample & $f(206) \%$ & $\mathrm{Th} / \mathrm{U}$ & $6 / 4$ ratio & $7 / 6$ ratio & $1 \mathrm{~s}(\%)$ & $7 / 5$ ratio & $1 \mathrm{~s}(\%)$ & $6 / 8$ ratio & $1 \mathrm{~s}(\%)$ & Rho & $7 / 6$ age & $1 \mathrm{~s}(\mathrm{Ma})$ & $7 / 5$ age & 1s(Ma) & $6 / 8$ age & $1 \mathrm{~s}(\mathrm{Ma})$ & Conc $(\%)$ \\
\hline \multicolumn{18}{|c|}{ Sample NI-V-95 } \\
\hline 003-Z1 & 0.00 & 0.23 & 466349.36 & 0.14 & 0.3 & 7.87 & 0.8 & 0.42 & 0.7 & 0.91 & 2184.0 & 5.4 & 2216.6 & 7.1 & 2252.1 & 13.85 & 103.12 \\
\hline 004-Z2 & 0.01 & 0.30 & 203600.21 & 0.14 & 0.3 & 7.71 & 0.7 & 0.41 & 0.7 & 0.89 & 2178.9 & 5.5 & 2197.2 & 6.7 & 2216.8 & 12.74 & 101.74 \\
\hline $005-\mathrm{Z3}$ & 0.01 & 0.24 & 284695.79 & 0.14 & 0.3 & 8.05 & 0.8 & 0.43 & 0.7 & 0.89 & 2192.6 & 5.6 & 2236.2 & 7.0 & 2284.2 & 13.53 & 104.18 \\
\hline 006-Z4 & 0.07 & 0.21 & 19883.53 & 0.13 & 0.8 & 7.33 & 1.2 & 0.39 & 0.9 & 0.88 & 2162.2 & 13.5 & 2152.1 & 10.6 & 2141.6 & 16.45 & 99.04 \\
\hline 009-Z5 & 0.06 & 0.23 & 24246.17 & 0.14 & 0.4 & 7.83 & 0.8 & 0.41 & 0.7 & 0.84 & 2195.2 & 6.7 & 2211.1 & 7.0 & 2228.3 & 12.74 & 101.51 \\
\hline 010-Z6 & 0.01 & 0.23 & 251638.17 & 0.14 & 0.3 & 7.93 & 1.2 & 0.42 & 1.1 & 0.96 & 2197.4 & 5.3 & 2223.4 & 10.4 & 2251.6 & 21.15 & 102.47 \\
\hline 011-Z7 & 0.01 & 0.27 & 291012.52 & 0.14 & 0.3 & 7.78 & 0.6 & 0.41 & 0.6 & 0.87 & 2201.2 & 4.7 & 2206.1 & 5.8 & 2211.3 & 10.82 & 100.46 \\
\hline 012-Z8 & 0.01 & 0.30 & 160639.07 & 0.13 & 0.8 & 6.14 & 1.2 & 0.34 & 0.9 & 0.88 & 2108.3 & 13.5 & 1995.4 & 10.1 & 1888.2 & 14.08 & 89.56 \\
\hline 015-Z9 & 0.01 & 0.24 & 224771.76 & 0.14 & 0.4 & 8.01 & 1.1 & 0.42 & 1.0 & 0.93 & 2191.4 & 6.7 & 2231.8 & 10.0 & 2276.0 & 20.01 & 103.86 \\
\hline 016-Z10 & 0.00 & 0.24 & 402136.91 & 0.14 & 0.3 & 7.81 & 0.8 & 0.41 & 0.7 & 0.93 & 2198.1 & 4.8 & 2209.1 & 7.1 & 2220.9 & 13.98 & 101.04 \\
\hline 017-Z11 & 0.03 & 0.22 & 59736.17 & 0.13 & 0.3 & 6.62 & 0.8 & 0.36 & 0.8 & 0.94 & 2134.3 & 4.4 & 2062.6 & 7.2 & 1991.6 & 13.21 & 93.31 \\
\hline 021-Z13 & 0.01 & 0.22 & 136648.48 & 0.14 & 0.3 & 7.83 & 0.7 & 0.42 & 0.7 & 0.91 & 2174.8 & 4.6 & 2211.4 & 6.5 & 2251.2 & 12.69 & 103.51 \\
\hline 022-Z14 & 0.02 & 0.31 & 87810.07 & 0.14 & 0.4 & 7.87 & 0.8 & 0.42 & 0.7 & 0.83 & 2176.0 & 6.7 & 2216.8 & 6.9 & 2261.2 & 12.56 & 103.91 \\
\hline 023-Z15 & 0.00 & 0.34 & 625841.32 & 0.14 & 0.2 & 7.76 & 0.6 & 0.41 & 0.5 & 0.89 & 2191.3 & 4.0 & 2203.4 & 5.2 & 2216.3 & 10.02 & 101.14 \\
\hline 024-Z16 & 0.00 & 0.36 & 554400.65 & 0.14 & 0.4 & 7.69 & 0.8 & 0.40 & 0.6 & 0.89 & 2199.3 & 7.3 & 2195.5 & 6.8 & 2191.5 & 11.81 & 99.64 \\
\hline 027-Z17 & 0.00 & 0.20 & 429071.21 & 0.14 & 0.4 & 7.32 & 0.8 & 0.39 & 0.7 & 0.87 & 2183.5 & 6.6 & 2151.1 & 7.4 & 2117.3 & 13.40 & 96.97 \\
\hline 028-Z18 & 0.00 & 0.42 & 357532.11 & 0.14 & 0.3 & 7.82 & 0.7 & 0.41 & 0.7 & 0.90 & 2197.1 & 4.8 & 2210.2 & 6.4 & 2224.2 & 12.23 & 101.23 \\
\hline 030-Z19B & 0.15 & 0.26 & 9546.09 & 0.14 & 0.5 & 7.67 & 0.9 & 0.40 & 0.8 & 0.89 & 2205.1 & 9.4 & 2193.2 & 8.5 & 2180.5 & 14.23 & 98.88 \\
\hline 033-Z20 & 0.00 & 0.25 & 315467.17 & 0.13 & 0.4 & 6.61 & 1.4 & 0.36 & 1.3 & 0.95 & 2140.4 & 7.4 & 2061.0 & 11.9 & 1982.5 & 21.96 & 92.62 \\
\hline 034-Z21 & 0.00 & 0.36 & 643902.04 & 0.14 & 0.3 & 7.99 & 0.9 & 0.42 & 0.8 & 0.94 & 2201.9 & 5.1 & 2229.9 & 8.0 & 2260.6 & 16.00 & 102.66 \\
\hline 036-Z23 & 0.00 & 0.34 & 802651.62 & 0.14 & 0.4 & 8.05 & 0.7 & 0.42 & 0.6 & 0.87 & 2197.4 & 6.5 & 2236.3 & 6.1 & 2279.1 & 10.90 & 103.71 \\
\hline 039-Z24 & 0.00 & 0.33 & 456473.49 & 0.14 & 0.3 & 7.78 & 0.8 & 0.41 & 0.7 & 0.91 & 2194.6 & 5.3 & 2206.3 & 7.1 & 2218.9 & 13.65 & 101.11 \\
\hline 041-Z26 & 0.01 & 0.29 & 258823.21 & 0.14 & 0.3 & 6.99 & 1.1 & 0.37 & 1.0 & 0.96 & 2171.2 & 5.0 & 2109.9 & 9.4 & 2047.6 & 17.95 & 94.31 \\
\hline 045-Z28 & 0.00 & 0.27 & 317310.69 & 0.14 & 0.3 & 6.99 & 0.8 & 0.37 & 0.8 & 0.94 & 2195.0 & 4.6 & 2110.6 & 7.4 & 2025.2 & 13.81 & 92.27 \\
\hline 046-Z29 & 0.13 & 0.20 & 12500.65 & 0.12 & 0.4 & 4.19 & 1.0 & 0.25 & 0.9 & 0.91 & 2001.0 & 7.0 & 1671.6 & 8.3 & 1422.0 & 11.94 & 71.07 \\
\hline 047-Z30 & 0.01 & 0.25 & 120104.19 & 0.14 & 0.2 & 7.69 & 0.6 & 0.41 & 0.6 & 0.91 & 2187.6 & 3.8 & 2195.7 & 5.4 & 2204.3 & 10.43 & 100.77 \\
\hline 048-Z31 & 0.01 & 0.29 & 188428.18 & 0.13 & 0.4 & 7.26 & 0.9 & 0.39 & 0.8 & 0.94 & 2151.2 & 6.7 & 2143.5 & 7.8 & 2135.4 & 14.30 & 99.27 \\
\hline 053-Z24 & 0.00 & 0.23 & 352275.02 & 0.14 & 0.2 & 7.60 & 0.6 & 0.41 & 0.6 & 0.90 & 2171.2 & 4.2 & 2185.2 & 5.7 & 2200.1 & 10.89 & 101.33 \\
\hline 057-Z36 & 0.05 & 0.19 & 29071.07 & 0.14 & 0.3 & 7.14 & 0.8 & 0.38 & 0.8 & 0.92 & 2192.5 & 5.3 & 2129.0 & 7.4 & 2063.8 & 13.74 & 94.13 \\
\hline
\end{tabular}


4. Evolução crustal riaciana do embasamento paleoproterozóico da Faixa Brasília

\begin{tabular}{|c|c|c|c|c|c|c|c|c|c|c|c|c|c|c|c|c|c|}
\hline 058-Z37 & 0.01 & 0.25 & 213353.25 & 0.14 & 0.2 & 7.18 & 0.8 & 0.38 & 0.7 & 0.94 & 2173.1 & 4.2 & 2134.0 & 6.7 & 2093.6 & 12.70 & 96.34 \\
\hline 058-Z38 & 0.02 & 0.32 & 69690.14 & 0.13 & 0.3 & 6.84 & 0.7 & 0.37 & 0.6 & 0.90 & 2162.7 & 4.6 & 2090.9 & 6.0 & 2018.7 & 10.83 & 93.34 \\
\hline 060-Z39 & 0.23 & 0.29 & 6909.20 & 0.13 & 0.9 & 5.60 & 1.5 & 0.31 & 1.2 & 0.91 & 2097.8 & 16.0 & 1915.7 & 13.0 & 1752.1 & 18.46 & 83.52 \\
\hline Sample & $\mathrm{f}(206) \%$ & $\mathrm{Th} / \mathrm{U}$ & $6 / 4$ ratio & $7 / 6$ ratio & $1 \mathrm{~s}(\%)$ & $7 / 5$ ratio & $1 \mathrm{~s}(\%)$ & $6 / 8$ ratio & $1 \mathrm{~s}(\%)$ & Rho & $7 / 6$ age & $1 \mathrm{~s}(\mathrm{Ma})$ & $7 / 5$ age & $1 \mathrm{~s}(\mathrm{Ma})$ & $6 / 8$ age & $1 \mathrm{~s}(\mathrm{Ma})$ & Conc $(\%)$ \\
\hline \multicolumn{18}{|c|}{ Sample G7 } \\
\hline 004-Z01 & 0.61 & 0.14 & 2815.58 & 0.14 & 1.7 & 2.80 & 4.4 & 0.15 & 4.1 & 0.93 & 2198.2 & 29.0 & 1355.0 & 33.2 & 886.3 & 34.06 & 40.32 \\
\hline 005-Z31 & 0.03 & 0.31 & 50719.13 & 0.13 & 1.4 & 6.65 & 2.2 & 0.36 & 1.7 & 0.77 & 2149.1 & 24.2 & 2065.8 & 19.3 & 1983.3 & 28.78 & 92.29 \\
\hline 006-Z03 & 0.02 & 0.21 & 87841.86 & 0.14 & 2.1 & 4.99 & 3.5 & 0.26 & 2.7 & 0.91 & 2188.2 & 36.6 & 1817.3 & 29.2 & 1511.6 & 36.93 & 69.08 \\
\hline 006-Z32 & 0.03 & 0.16 & 50280.55 & 0.13 & 1.7 & 3.47 & 3.2 & 0.19 & 2.6 & 0.94 & 2151.4 & 30.5 & 1519.6 & 24.9 & 1108.2 & 26.75 & 51.51 \\
\hline 010-Z34 & 0.03 & 0.29 & 50973.19 & 0.14 & 2.5 & 3.73 & 3.4 & 0.20 & 2.2 & 0.66 & 2178.1 & 44.4 & 1578.0 & 27.2 & 1169.0 & 24.00 & 53.67 \\
\hline 011-Z06 & 0.06 & 0.16 & 26910.45 & 0.14 & 1.0 & 2.91 & 3.1 & 0.16 & 3.0 & 0.95 & 2171.6 & 17.4 & 1384.2 & 23.7 & 932.2 & 25.84 & 42.93 \\
\hline 016-Z09 & 0.45 & 0.19 & 3604.27 & 0.14 & 0.9 & 4.89 & 3.1 & 0.26 & 3.0 & 0.96 & 2193.7 & 15.9 & 1800.2 & 26.4 & 1480.5 & 39.67 & 67.49 \\
\hline 016-Z38 & 0.01 & 0.23 & 125625.81 & 0.13 & 0.7 & 7.37 & 1.1 & 0.40 & 0.8 & 0.77 & 2158.2 & 11.4 & 2157.5 & 9.5 & 2156.6 & 15.44 & 99.93 \\
\hline 017-Z10 & 0.01 & 0.34 & 119642.24 & 0.14 & 1.1 & 5.78 & 1.6 & 0.31 & 1.2 & 0.72 & 2193.6 & 19.3 & 1943.7 & 14.2 & 1717.9 & 18.11 & 78.31 \\
\hline 017-Z39 & 0.06 & 0.29 & 28216.40 & 0.13 & 0.6 & 3.72 & 2.1 & 0.21 & 2.0 & 0.96 & 2114.0 & 10.2 & 1575.2 & 17.0 & 1205.0 & 22.39 & 57.00 \\
\hline 018-Z11 & 0.06 & 0.24 & 27081.17 & 0.14 & 1.6 & 6.47 & 1.8 & 0.35 & 1.0 & 0.66 & 2173.0 & 27.6 & 2042.5 & 16.3 & 1915.8 & 15.80 & 88.16 \\
\hline 022-Z13 & 0.01 & 0.16 & 190224.57 & 0.14 & 1.0 & 7.30 & 1.3 & 0.39 & 0.9 & 0.65 & 2176.6 & 16.9 & 2148.6 & 11.7 & 2119.3 & 15.92 & 97.37 \\
\hline 023-Z14 & 0.32 & 0.19 & 4980.90 & 0.14 & 1.3 & 5.02 & 2.3 & 0.27 & 1.9 & 0.82 & 2174.2 & 22.8 & 1822.0 & 19.5 & 1530.1 & 25.87 & 70.38 \\
\hline 029-Z17 & 0.02 & 0.30 & 64885.69 & 0.14 & 1.0 & 7.10 & 1.8 & 0.38 & 1.5 & 0.83 & 2169.9 & 16.8 & 2124.6 & 15.7 & 2078.0 & 26.14 & 95.77 \\
\hline 030-Z18 & 0.00 & 0.23 & 329690.94 & 0.14 & 1.8 & 7.23 & 2.0 & 0.39 & 1.0 & 0.66 & 2170.6 & 30.9 & 2140.0 & 18.1 & 2108.2 & 17.83 & 97.12 \\
\hline 033-Z19 & 0.00 & 0.22 & 434778.44 & 0.13 & 1.0 & 5.31 & 1.7 & 0.29 & 1.4 & 0.82 & 2154.1 & 17.0 & 1870.7 & 14.7 & 1626.4 & 20.45 & 75.50 \\
\hline 034-Z20 & 0.47 & 0.34 & 3405.68 & 0.14 & 1.0 & 5.04 & 2.4 & 0.27 & 2.2 & 0.92 & 2174.0 & 16.8 & 1826.2 & 20.6 & 1537.1 & 30.43 & 70.70 \\
\hline 035-Z21 & 0.07 & 0.24 & 23250.83 & 0.14 & 0.8 & 4.76 & 3.2 & 0.25 & 3.1 & 0.97 & 2183.9 & 13.4 & 1777.6 & 26.5 & 1452.6 & 39.83 & 66.51 \\
\hline 036-Z22 & 0.01 & 0.20 & 275683.99 & 0.13 & 0.9 & 5.05 & 3.4 & 0.27 & 3.3 & 0.97 & 2161.2 & 15.9 & 1828.2 & 28.7 & 1550.4 & 44.95 & 71.74 \\
\hline 039-Z23 & 0.02 & 0.21 & 66462.65 & 0.13 & 1.0 & 5.60 & 2.2 & 0.30 & 2.0 & 0.90 & 2156.6 & 16.9 & 1916.7 & 18.9 & 1703.0 & 29.54 & 78.96 \\
\hline 040-Z24 & 0.02 & 0.18 & 96242.79 & 0.13 & 1.0 & 5.44 & 2.6 & 0.29 & 2.4 & 0.92 & 2153.3 & 17.3 & 1890.5 & 22.0 & 1660.7 & 34.70 & 77.12 \\
\hline $041-Z 25$ & 0.01 & 0.25 & 207479.74 & 0.13 & 0.8 & 5.49 & 1.9 & 0.30 & 1.7 & 0.89 & 2135.0 & 14.6 & 1899.6 & 16.3 & 1691.7 & 25.30 & 79.24 \\
\hline 042-Z26 & 0.01 & 0.26 & 255068.69 & 0.13 & 2.1 & 4.10 & 3.9 & 0.22 & 3.3 & 0.93 & 2163.4 & 37.4 & 1653.8 & 32.1 & 1283.0 & 38.34 & 59.31 \\
\hline $045-Z 27$ & 0.03 & 0.20 & 53899.13 & 0.14 & 1.3 & 2.18 & 3.6 & 0.11 & 3.4 & 0.94 & 2199.0 & 22.0 & 1174.3 & 25.0 & 700.1 & 22.29 & 31.84 \\
\hline 046-Z28 & 0.02 & 0.23 & 68272.56 & 0.14 & 1.2 & 3.31 & 3.6 & 0.18 & 3.4 & 0.95 & 2173.1 & 20.2 & 1484.3 & 28.3 & 1051.1 & 33.40 & 48.37 \\
\hline 047-Z29 & 0.01 & 0.25 & 179984.18 & 0.14 & 1.2 & 6.98 & 1.7 & 0.37 & 1.2 & 0.70 & 2170.2 & 21.4 & 2108.9 & 15.4 & 2046.5 & 21.55 & 94.30 \\
\hline
\end{tabular}




\begin{tabular}{|c|c|c|c|c|c|c|c|c|c|c|c|c|c|c|c|c|c|}
\hline \multicolumn{17}{|c|}{ Sample G2 } & Conc $(\%)$ \\
\hline 004-Z01 & 0.01 & 0.61 & 122674.75 & 0.15 & 0.4 & 9.41 & 1.6 & 0.46 & 1.6 & 0.97 & 2338.5 & 6.1 & 2379.2 & 14.7 & 2427.1 & 31.63 & 103.79 \\
\hline 005-Z02 & 0.25 & 0.60 & 5735.69 & 0.15 & 0.4 & 8.69 & 2.0 & 0.42 & 2.0 & 0.98 & 2327.9 & 6.3 & 2305.7 & 18.1 & 2280.7 & 37.54 & 97.97 \\
\hline 006-Z03 & 0.13 & 0.24 & 11812.07 & 0.15 & 0.7 & 7.70 & 2.1 & 0.37 & 2.0 & 0.98 & 2345.3 & 11.3 & 2196.7 & 18.9 & 2041.1 & 34.88 & 87.03 \\
\hline 009-Z04 & 0.00 & 0.02 & 390164.64 & 0.13 & 0.4 & 6.80 & 1.2 & 0.38 & 1.1 & 0.94 & 2106.5 & 7.0 & 2085.9 & 10.3 & 2065.0 & 19.41 & 98.03 \\
\hline 010-Z05 & 0.07 & 0.69 & 46126.39 & 0.13 & 1.7 & 3.90 & 7.0 & 0.22 & 6.8 & 0.97 & 2117.6 & 30.1 & 1614.5 & 56.6 & 1257.3 & 77.54 & 59.38 \\
\hline 011-Z06 & 0.01 & 0.28 & 123305.76 & 0.13 & 0.4 & 7.87 & 1.1 & 0.43 & 1.0 & 0.90 & 2132.7 & 7.7 & 2216.3 & 9.5 & 2307.8 & 18.48 & 108.21 \\
\hline 012-Z07 & 1.55 & 0.19 & 1104.41 & 0.14 & 0.8 & 3.15 & 2.9 & 0.17 & 2.8 & 0.99 & 2182.6 & 14.5 & 1443.9 & 22.7 & 996.6 & 26.06 & 45.66 \\
\hline 015-Z08 & 0.99 & 0.84 & 1543.44 & 0.16 & 0.5 & 7.80 & 2.2 & 0.35 & 2.2 & 0.97 & 2450.3 & 8.3 & 2208.5 & 19.9 & 1957.5 & 36.39 & 79.89 \\
\hline 016-Z09 & 0.01 & 0.35 & 974987.79 & 0.14 & 0.5 & 8.08 & 1.4 & 0.41 & 1.4 & 0.93 & 2257.6 & 8.7 & 2239.6 & 13.1 & 2220.0 & 25.48 & 98.34 \\
\hline 017-Z10 & 0.02 & 0.67 & 67357.84 & 0.15 & 0.4 & 9.40 & 1.1 & 0.45 & 1.0 & 0.93 & 2344.8 & 6.8 & 2377.7 & 10.2 & 2416.2 & 20.95 & 103.04 \\
\hline 018-Z11 & 0.11 & 0.79 & 13886.44 & 0.15 & 0.7 & 7.59 & 1.5 & 0.36 & 1.3 & 0.94 & 2389.8 & 12.6 & 2183.8 & 13.2 & 1971.3 & 21.60 & 82.49 \\
\hline 021-Z12 & 0.28 & 0.70 & 5341.37 & 0.15 & 0.4 & 7.60 & 1.4 & 0.37 & 1.3 & 0.95 & 2348.7 & 7.4 & 2185.2 & 12.3 & 2015.2 & 22.60 & 85.80 \\
\hline 022-Z13 & 0.04 & 0.87 & 71779.09 & 0.15 & 0.5 & 5.74 & 2.1 & 0.29 & 2.0 & 0.97 & 2299.7 & 8.8 & 1938.0 & 17.9 & 1618.1 & 28.73 & 70.36 \\
\hline 023-Z14 & 0.03 & 0.33 & 54631.47 & 0.15 & 0.4 & 7.54 & 1.3 & 0.37 & 1.2 & 0.94 & 2328.8 & 7.1 & 2177.8 & 11.4 & 2021.2 & 20.95 & 86.79 \\
\hline 024-Z15 & 0.17 & 0.27 & 8897.16 & 0.15 & 0.7 & 7.31 & 1.8 & 0.36 & 1.6 & 0.96 & 2307.5 & 12.9 & 2149.4 & 16.2 & 1987.9 & 28.22 & 86.15 \\
\hline 027-Z16 & 0.03 & 0.19 & 45992.77 & 0.14 & 0.6 & 6.31 & 2.3 & 0.34 & 2.2 & 0.96 & 2175.9 & 11.0 & 2019.2 & 20.2 & 1869.6 & 36.05 & 85.92 \\
\hline 028-Z17 & 0.06 & 0.33 & 48534.82 & 0.15 & 0.4 & 7.39 & 1.6 & 0.36 & 1.6 & 0.96 & 2320.2 & 7.6 & 2159.2 & 14.6 & 1994.0 & 27.03 & 85.94 \\
\hline 029-Z18 & 0.08 & 0.85 & 18857.39 & 0.15 & 0.6 & 8.60 & 2.4 & 0.41 & 2.3 & 0.97 & 2360.1 & 10.7 & 2296.6 & 22.0 & 2225.9 & 44.07 & 94.31 \\
\hline 030-Z19 & 0.02 & 0.68 & 94894.76 & 0.14 & 0.8 & 7.97 & 1.2 & 0.40 & 0.9 & 0.87 & 2275.6 & 13.2 & 2227.4 & 10.9 & 2175.5 & 17.27 & 95.60 \\
\hline Sample & $f(206) \%$ & $\mathrm{Th} / \mathrm{U}$ & $6 / 4$ ratio & $7 / 6$ ratio & $1 \mathrm{~s}(\%)$ & $7 / 5$ ratio & $1 \mathrm{~s}(\%)$ & $6 / 8$ ratio & $1 \mathrm{~s}(\%)$ & Rho & $7 / 6$ age & $1 \mathrm{~s}(\mathrm{Ma})$ & $7 / 5$ age & $1 \mathrm{~s}(\mathrm{Ma})$ & $6 / 8$ age & $1 \mathrm{~s}(\mathrm{Ma})$ & Conc $(\%)$ \\
\hline \multicolumn{18}{|c|}{ Sample G1 } \\
\hline 034-Z21 & 0.40 & 0.21 & 3430.92 & 0.14 & 0.5 & 8.14 & 1.8 & 0.43 & 1.8 & 0.97 & 2186.0 & 8.2 & 2246.4 & 16.7 & 2313.4 & 34.67 & 105.83 \\
\hline 040-Z25 & 0.58 & 0.34 & 1398.95 & 0.13 & 0.5 & 6.76 & 1.8 & 0.38 & 1.7 & 0.95 & 2096.1 & 9.2 & 2080.3 & 15.7 & 2064.4 & 29.86 & 98.49 \\
\hline 041-Z26 & 1.30 & 0.68 & 1166.26 & 0.13 & 0.8 & 6.43 & 2.0 & 0.36 & 1.8 & 0.91 & 2099.6 & 14.4 & 2036.8 & 17.6 & 1975.4 & 31.17 & 94.09 \\
\hline 042-Z27 & 0.10 & 0.41 & 14661.64 & 0.13 & 1.1 & 6.93 & 1.5 & 0.38 & 1.1 & 0.87 & 2131.9 & 18.7 & 2102.8 & 13.6 & 2073.1 & 19.55 & 97.25 \\
\hline $045-Z 28$ & 0.04 & 0.30 & 39662.40 & 0.13 & 0.6 & 7.37 & 1.9 & 0.40 & 1.8 & 0.94 & 2160.1 & 11.0 & 2157.4 & 17.2 & 2154.6 & 33.23 & 99.74 \\
\hline Sample & $\mathrm{f}(206) \%$ & $\mathrm{Th} / \mathrm{U}$ & $6 / 4$ ratio & $7 / 6$ ratio & $1 \mathrm{~s}(\%)$ & $7 / 5$ ratio & $1 \mathrm{~s}(\%)$ & $6 / 8$ ratio & $1 \mathrm{~s}(\%)$ & Rho & $7 / 6$ age & 1s(Ma) & $7 / 5$ age & $1 \mathrm{~s}(\mathrm{Ma})$ & $6 / 8$ age & 1s(Ma) & Conc $(\%)$ \\
\hline
\end{tabular}


4. Evolução crustal riaciana do embasamento paleoproterozóico da Faixa Brasília

\begin{tabular}{|c|c|c|c|c|c|c|c|c|c|c|c|c|c|c|c|c|c|}
\hline \multicolumn{18}{|c|}{ imple PI-14 } \\
\hline 004-Z1 & 0.01 & 0.27 & 113865.44 & 0.14 & 0.5 & 7.14 & 1.0 & 0.38 & 0.9 & 0.88 & 2170.3 & 8.1 & 2128.7 & 9.1 & 2085.9 & 16.28 & 96.11 \\
\hline 005-Z2 & 0.52 & 0.34 & 3004.67 & 0.14 & 0.4 & 5.58 & 0.8 & 0.30 & 0.6 & 0.79 & 2167.0 & 7.5 & 1913.0 & 6.5 & 1687.6 & 9.28 & 77.88 \\
\hline 006-Z3 & 0.29 & 0.23 & 5384.68 & 0.14 & 0.4 & 6.04 & 1.6 & 0.31 & 1.6 & 0.96 & 2232.5 & 7.6 & 1981.6 & 14.2 & 1750.2 & 24.01 & 78.40 \\
\hline $008-\mathrm{Z} 5 \mathrm{~N}$ & 2.32 & 0.27 & 707.09 & 0.13 & 0.8 & 4.14 & 1.3 & 0.23 & 1.0 & 0.82 & 2107.1 & 13.7 & 1661.7 & 10.6 & 1332.4 & 12.58 & 63.23 \\
\hline 010-Z6 & 0.01 & 0.16 & 193610.94 & 0.13 & 0.3 & 6.52 & 0.9 & 0.35 & 0.9 & 0.93 & 2143.3 & 5.7 & 2048.6 & 8.1 & 1955.9 & 14.55 & 91.26 \\
\hline 017-Z11 & 0.02 & 0.48 & 88884.18 & 0.14 & 0.5 & 7.36 & 0.9 & 0.39 & 0.7 & 0.75 & 2177.1 & 9.3 & 2156.3 & 7.7 & 2134.5 & 12.40 & 98.04 \\
\hline 018-Z12 & 0.28 & 0.16 & 5536.02 & 0.14 & 0.5 & 5.90 & 1.0 & 0.30 & 0.8 & 0.86 & 2238.8 & 8.2 & 1962.0 & 8.4 & 1710.4 & 12.66 & 76.40 \\
\hline $020-Z 14$ & 0.00 & 0.27 & 1415304.54 & 0.13 & 0.4 & 6.52 & 1.3 & 0.35 & 1.3 & 0.94 & 2159.1 & 7.6 & 2048.7 & 11.8 & 1940.9 & 21.24 & 89.89 \\
\hline 024-Z15 & 0.39 & 0.39 & 3884.42 & 0.13 & 0.6 & 6.65 & 1.1 & 0.36 & 0.9 & 0.80 & 2143.0 & 10.7 & 2065.8 & 9.2 & 1989.3 & 14.56 & 92.83 \\
\hline 026-Z17 & 0.17 & 0.23 & 8861.38 & 0.14 & 0.4 & 6.72 & 0.8 & 0.36 & 0.7 & 0.85 & 2164.8 & 6.4 & 2074.6 & 6.7 & 1985.0 & 11.30 & 91.69 \\
\hline 027-Z18 & 0.03 & 0.32 & 51211.98 & 0.14 & 0.4 & 7.16 & 1.0 & 0.38 & 0.9 & 0.88 & 2178.4 & 7.6 & 2131.0 & 8.7 & 2082.2 & 15.63 & 95.58 \\
\hline 028-Z19 & 0.00 & 0.28 & 586732.21 & 0.14 & 0.4 & 7.29 & 0.7 & 0.39 & 0.6 & 0.82 & 2184.1 & 6.4 & 2147.0 & 6.4 & 2108.5 & 11.08 & 96.54 \\
\hline 029-Z20N & 0.19 & 0.20 & 7987.08 & 0.14 & 0.4 & 7.71 & 0.9 & 0.40 & 0.8 & 0.85 & 2233.9 & 7.5 & 2197.2 & 8.0 & 2158.1 & 14.26 & 96.61 \\
\hline 030-Z20B & 0.02 & 0.11 & 88925.77 & 0.14 & 0.4 & 7.46 & 0.7 & 0.39 & 0.5 & 0.73 & 2204.0 & 7.0 & 2168.4 & 6.0 & 2131.0 & 9.69 & 96.68 \\
\hline $035-Z 23$ & 0.03 & 0.28 & 53749.36 & 0.14 & 0.4 & 6.93 & 0.7 & 0.37 & 0.6 & 0.82 & 2164.1 & 6.5 & 2102.7 & 6.4 & 2040.5 & 10.89 & 94.29 \\
\hline 036-Z24 & 0.78 & 0.49 & 2128.33 & 0.11 & 0.5 & 3.29 & 0.9 & 0.22 & 0.8 & 0.85 & 1814.0 & 8.4 & 1478.2 & 6.9 & 1255.7 & 8.73 & 69.23 \\
\hline 039-Z27 & 0.18 & 0.30 & 8030.04 & 0.14 & 0.9 & 7.49 & 1.2 & 0.40 & 0.7 & 0.60 & 2179.8 & 15.5 & 2171.4 & 10.4 & 2162.5 & 13.68 & 99.20 \\
\hline 040-Z28 & 0.00 & 0.25 & 389579.36 & 0.13 & 0.6 & 7.39 & 0.9 & 0.40 & 0.7 & 0.75 & 2162.9 & 9.7 & 2159.9 & 8.0 & 2156.8 & 12.98 & 99.72 \\
\hline Sample & $\mathrm{f}(206) \%$ & $\mathrm{Th} / \mathrm{U}$ & $6 / 4$ ratio & $7 / 6$ ratio & $1 \mathrm{~s}(\%)$ & $7 / 5$ ratio & $1 \mathrm{~s}(\%)$ & $6 / 8$ ratio & $1 \mathrm{~s}(\%)$ & Rho & 7/6 age & 1s(Ma) & $7 / 5$ age & 1s(Ma) & $6 / 8$ age & 1s(Ma) & Conc $(\%)$ \\
\hline \multicolumn{18}{|c|}{ Sample NI-I-50 } \\
\hline $005-\mathrm{Z3}$ & 0.02 & 0.11 & 69971.91 & 0.14 & 0.4 & 8.11 & 0.8 & 0.43 & 0.7 & 0.86 & 2189.4 & 6.7 & 2243.0 & 7.5 & 2302.2 & 14.13 & 105.15 \\
\hline 009-Z6B & 0.03 & 0.07 & 57138.48 & 0.13 & 0.6 & 7.33 & 0.9 & 0.40 & 0.6 & 0.69 & 2120.7 & 10.3 & 2152.8 & 7.8 & 2186.6 & 11.93 & 103.10 \\
\hline 010-Z7 & 0.01 & 0.42 & 202197.90 & 0.13 & 0.6 & 7.38 & 0.9 & 0.40 & 0.6 & 0.68 & 2159.0 & 10.9 & 2158.1 & 7.7 & 2157.2 & 10.73 & 99.92 \\
\hline 013-Z8 & 0.00 & 0.18 & 311779.19 & 0.14 & 0.5 & 8.08 & 0.8 & 0.43 & 0.6 & 0.68 & 2189.7 & 9.5 & 2239.6 & 7.3 & 2294.6 & 11.45 & 104.79 \\
\hline 014-Z9 & 0.03 & 0.40 & 54276.29 & 0.13 & 0.5 & 7.72 & 0.8 & 0.42 & 0.6 & 0.66 & 2148.7 & 9.2 & 2198.8 & 6.9 & 2253.0 & 10.70 & 104.85 \\
\hline 016-Z11C & 0.02 & 0.29 & 62725.57 & 0.14 & 0.8 & 8.21 & 1.4 & 0.43 & 1.1 & 0.90 & 2196.9 & 13.7 & 2254.8 & 12.4 & 2319.1 & 21.80 & 105.56 \\
\hline 017-Z11B & 0.01 & 0.20 & 212912.10 & 0.13 & 0.4 & 7.93 & 0.9 & 0.43 & 0.8 & 0.85 & 2154.9 & 7.6 & 2222.9 & 7.8 & 2297.5 & 14.55 & 106.61 \\
\hline 019-Z13 & 0.01 & 0.35 & 135965.18 & 0.13 & 0.6 & 7.53 & 1.0 & 0.42 & 0.8 & 0.81 & 2107.1 & 9.8 & 2176.2 & 8.9 & 2250.4 & 15.61 & 106.80 \\
\hline 023-Z14B & 0.10 & 0.26 & 16542.73 & 0.12 & 0.6 & 3.72 & 1.0 & 0.23 & 0.8 & 0.77 & 1916.0 & 10.6 & 1575.7 & 7.8 & 1334.3 & 9.35 & 69.64 \\
\hline 027-Z18 & 0.01 & 0.15 & 252405.38 & 0.14 & 0.4 & 7.37 & 1.4 & 0.39 & 1.4 & 0.95 & 2173.0 & 7.5 & 2157.3 & 12.7 & 2140.9 & 24.60 & 98.52 \\
\hline
\end{tabular}


4. Evolução crustal riaciana do embasamento paleoproterozóico da Faixa Brasília

\begin{tabular}{|c|c|c|c|c|c|c|c|c|c|c|c|c|c|c|c|c|c|}
\hline 030-Z20 & 0.05 & 0.14 & 29896.88 & 0.14 & 0.7 & 7.34 & 1.1 & 0.39 & 0.8 & 0.82 & 2172.5 & 12.6 & 2153.7 & 9.6 & 2134.0 & 14.50 & 98.23 \\
\hline 034-Z22 & 0.45 & 0.37 & 3249.52 & 0.14 & 0.7 & 7.75 & 1.1 & 0.41 & 0.8 & 0.76 & 2176.4 & 11.4 & 2202.1 & 9.6 & 2229.8 & 15.89 & 102.45 \\
\hline $035-Z 23$ & 0.00 & 0.22 & 1506201.38 & 0.13 & 0.4 & 7.68 & 0.8 & 0.41 & 0.7 & 0.83 & 2158.5 & 7.0 & 2194.4 & 7.1 & 2233.0 & 12.72 & 103.45 \\
\hline 036-Z24 & 0.00 & 0.18 & 2345132.12 & 0.13 & 0.5 & 7.47 & 0.9 & 0.41 & 0.8 & 0.86 & 2142.0 & 8.9 & 2169.6 & 8.2 & 2198.9 & 14.20 & 102.66 \\
\hline 037-Z25 & 0.00 & 0.70 & 324419.14 & 0.13 & 0.5 & 8.20 & 1.0 & 0.44 & 0.9 & 0.87 & 2150.6 & 8.6 & 2252.9 & 9.3 & 2367.3 & 17.94 & 110.08 \\
\hline 038-Z26 & 0.30 & 0.37 & 4926.31 & 0.14 & 0.5 & 7.93 & 1.1 & 0.41 & 0.9 & 0.86 & 2220.9 & 9.2 & 2223.6 & 9.7 & 2226.5 & 17.65 & 100.25 \\
\hline 039-Z27 & 0.00 & 0.19 & 556904.24 & 0.14 & 0.5 & 8.12 & 1.0 & 0.43 & 0.9 & 0.87 & 2194.7 & 8.6 & 2244.7 & 9.4 & 2299.9 & 17.76 & 104.79 \\
\hline
\end{tabular}


Table 4.3: Whole rock chemistry results from Natividade basement (1/4)

\begin{tabular}{|c|c|c|c|c|c|c|c|c|c|}
\hline & PI 2 & PI 3 & PI 4 & PI 25 & PI 26 & PI 41 & $\begin{array}{r}\text { NI-VIII- } \\
122\end{array}$ & NI-X-22 & $\begin{array}{r}\text { NI-VIII- } \\
164 \mathrm{~F}\end{array}$ \\
\hline Unit & $\mathrm{RM}$ & $\mathrm{RM}$ & $\mathrm{RM}$ & RM & RM & RM & RM & RM & RM \\
\hline $\mathrm{SiO} 2 \%$ & 70.63 & 64.38 & 67.99 & 70.93 & 70.54 & 70.75 & 68.34 & 62.9 & 63.12 \\
\hline $\mathrm{Al} 2 \mathrm{O} 3$ & 14.77 & 16.32 & 15.07 & 15.09 & 16.04 & 15.35 & 15 & 16.78 & 17.15 \\
\hline $\mathrm{Fe} 2 \mathrm{O} 3$ & 2.41 & 4.67 & 3.61 & 2.37 & 2.32 & 2.45 & 3.21 & 5.32 & 4.82 \\
\hline $\mathrm{MgO}$ & 1.08 & 1.45 & 1.26 & 0.66 & 0.71 & 0.64 & 0.95 & 2.07 & 1.45 \\
\hline $\mathrm{CaO}$ & 1.1 & 3.9 & 3.3 & 2.54 & 3.19 & 2.65 & 3.06 & 4.48 & 4.05 \\
\hline $\mathrm{Na} 2 \mathrm{O}$ & 4.65 & 4.54 & 4.12 & 4.43 & 5.38 & 4.85 & 3.83 & 4.43 & 4.9 \\
\hline $\mathrm{K} 2 \mathrm{O}$ & 3.09 & 2.02 & 2.58 & 2.57 & 0.89 & 2.06 & 2.53 & 1.72 & 1.65 \\
\hline $\mathrm{TiO} 2$ & 0.26 & 0.54 & 0.41 & 0.23 & 0.24 & 0.23 & 0.32 & 0.49 & 0.51 \\
\hline $\mathrm{P} 2 \mathrm{O} 5$ & 0.08 & 0.24 & 0.16 & 0.08 & 0.05 & 0.09 & 0.17 & 0.19 & 0.18 \\
\hline $\mathrm{MnO}$ & 0.04 & 0.07 & 0.06 & 0.05 & 0.03 & 0.05 & 0.04 & 0.09 & 0.07 \\
\hline $\mathrm{Cr}$ & $<0.002$ & $<0.002$ & $<0.002$ & $<0.002$ & $<0.002$ & $<0.002$ & $<0.002$ & 0.003 & $<0.002$ \\
\hline LOI & 1.7 & 1.6 & 1.2 & 0.8 & 0.5 & 0.7 & 2.1 & 1.1 & 1.7 \\
\hline TOTAL & 99.82 & 99.68 & 99.79 & 99.77 & 99.88 & 99.82 & 99.52 & 99.62 & 99.64 \\
\hline Ba ppm & 912 & 947 & 777 & 906 & 287 & 614 & 1363 & 840 & 775 \\
\hline Cs & 0.6 & 0.7 & 1.2 & 0.7 & 0.9 & 1.2 & 0.5 & 1.4 & 0.8 \\
\hline $\mathrm{Ga}$ & 16.1 & 21 & 18.1 & 19.1 & 17.4 & 19.1 & 19 & 20.2 & 23.3 \\
\hline $\mathrm{Hf}$ & 4.9 & 6.2 & 4.2 & 4.1 & 2.8 & 3.1 & 4.4 & 4.6 & 4.6 \\
\hline $\mathrm{Nb}$ & 6.9 & 9.6 & 6.2 & 5.4 & 1.5 & 4.4 & 5.7 & 5.6 & 7.7 \\
\hline $\mathrm{Rb}$ & 53.8 & 46.6 & 68.3 & 64.8 & 22.6 & 51.4 & 52.4 & 43.4 & 46 \\
\hline $\mathrm{Sr}$ & 272.7 & 935.1 & 563 & 593.5 & 522.7 & 693.2 & 804 & 751.5 & 870.8 \\
\hline $\mathrm{Ta}$ & 0.6 & 0.6 & 0.3 & 0.2 & 0.2 & 0.4 & 0.5 & 0.4 & 0.6 \\
\hline $\mathrm{Th}$ & 5.2 & 8 & 9.7 & 13 & 0.5 & 4.2 & 12.1 & 4 & 4.2 \\
\hline $\mathrm{U}$ & 1.6 & 1.1 & 2.1 & 1.5 & $<0.1$ & 1.7 & 1.3 & 0.8 & 1.4 \\
\hline $\mathrm{Sc}$ & 2 & 6 & 6 & 4 & 2 & 3 & 6 & 11 & 12 \\
\hline V & 28 & 52 & 52 & 25 & 22 & 21 & 51 & 101 & 69 \\
\hline $\mathrm{Zr}$ & 163.3 & 257.7 & 146.9 & 159.4 & 118.3 & 107.4 & 179.7 & 196.5 & 180.5 \\
\hline $\mathrm{Y}$ & 11.2 & 21.4 & 9.7 & 10.4 & 2.3 & 11.6 & 10.8 & 16.1 & 21.2 \\
\hline $\mathrm{Cu}$ & 2.1 & 10.8 & 6 & 10.5 & 1 & 4.7 & 4.6 & 25.3 & 15.5 \\
\hline $\mathrm{Pb}$ & 4.6 & 3.6 & 4.1 & 4.8 & 1.4 & 3.7 & 4.9 & 1.6 & 1.8 \\
\hline $\mathrm{Zn}$ & 33 & 70 & 49 & 52 & 48 & 54 & 31 & 66 & 81 \\
\hline $\mathrm{Ni}$ & 3 & 5.5 & 8.7 & 4.2 & 3.2 & 1.8 & 4.1 & 10.1 & 4.5 \\
\hline La ppm & 31.1 & 75.4 & 37.8 & 55.7 & 6.6 & 28.1 & 70.4 & 36.3 & 31 \\
\hline $\mathrm{Ce}$ & 58.7 & 149.1 & 73.6 & 107.6 & 14.7 & 45.4 & 130.5 & 70.2 & 59.8 \\
\hline $\operatorname{Pr}$ & 6.35 & 16.55 & 7.72 & 10.46 & 1.46 & 5.76 & 14.27 & 8.51 & 7.91 \\
\hline $\mathrm{Nd}$ & 23.6 & 58.4 & 26.7 & 35.9 & 5.5 & 21.2 & 49.9 & 32.8 & 30.9 \\
\hline $\mathrm{Sm}$ & 3.28 & 9.54 & 4.18 & 5.4 & 0.95 & 3.46 & 6.42 & 6.12 & 6.83 \\
\hline $\mathrm{Eu}$ & 0.82 & 2.15 & 1.06 & 1.23 & 0.52 & 0.99 & 1.51 & 1.57 & 2.05 \\
\hline Gd & 2.86 & 6.92 & 3.25 & 3.88 & 0.8 & 3.06 & 4.01 & 4.46 & 6.42 \\
\hline $\mathrm{Tb}$ & 0.38 & 0.89 & 0.38 & 0.47 & 0.1 & 0.4 & 0.43 & 0.57 & 0.86 \\
\hline Dy & 1.95 & 4.61 & 1.82 & 2.12 & 0.58 & 2.21 & 2.07 & 3.06 & 4.75 \\
\hline Ho & 0.41 & 0.88 & 0.38 & 0.4 & 0.1 & 0.43 & 0.37 & 0.55 & 0.84 \\
\hline $\mathrm{Er}$ & 1.17 & 2.53 & 0.97 & 1.12 & 0.29 & 1.16 & 0.92 & 1.51 & 1.94 \\
\hline Tm & 0.21 & 0.35 & 0.16 & 0.13 & 0.04 & 0.18 & 0.14 & 0.21 & 0.27 \\
\hline $\mathrm{Yb}$ & 1.36 & 1.86 & 1.05 & 0.73 & 0.2 & 1.33 & 0.9 & 1.26 & 1.38 \\
\hline $\mathrm{Lu}$ & 0.23 & 0.29 & 0.16 & 0.12 & 0.04 & 0.2 & 0.13 & 0.19 & 0.22 \\
\hline
\end{tabular}


4. Evolução crustal riaciana do embasamento paleoproterozóico da Faixa Brasília

Table 4.4: Whole rock chemistry results from Natividade basement (2/4).

\begin{tabular}{|c|c|c|c|c|c|c|c|c|c|}
\hline & $\begin{array}{r}\text { NI-VIII- } \\
164 \mathrm{G}\end{array}$ & PR-M-5A & PI 9MA & PI 10 & PI 20 & PI 35 & PI 42 & $\begin{array}{r}\text { NI-V- } \\
86 \mathrm{~A}\end{array}$ & $\begin{array}{r}\text { NI-V- } \\
95 \mathrm{~A}\end{array}$ \\
\hline Unit & $\mathrm{RM}$ & $\mathrm{RM}$ & MA & MA & MA & MA & MA & MA & MA \\
\hline $\mathrm{SiO} 2 \%$ & 69.87 & 66.19 & 69.92 & 67.72 & 76.27 & 77.19 & 69.75 & 58.13 & 69.83 \\
\hline $\mathrm{Al} 2 \mathrm{O} 3$ & 14.89 & 15.74 & 14.75 & 15 & 12.41 & 10.7 & 16.4 & 9.91 & 15.05 \\
\hline $\mathrm{Fe} 2 \mathrm{O} 3$ & 2.94 & 4.04 & 4.52 & 5.18 & 2.56 & 4.12 & 2.31 & 3.72 & 2.57 \\
\hline $\mathrm{MgO}$ & 0.77 & 1.51 & 1.34 & 1.54 & 0.8 & 0.9 & 0.72 & 1.44 & 1.06 \\
\hline $\mathrm{CaO}$ & 3.21 & 3.03 & 2.89 & 3.59 & 0.06 & 1.2 & 3.58 & 11.48 & 1.81 \\
\hline $\mathrm{Na} 2 \mathrm{O}$ & 4.44 & 4.48 & 3.62 & 3.25 & 3.55 & 1.72 & 4.85 & 2.75 & 4.81 \\
\hline $\mathrm{K} 2 \mathrm{O}$ & 1.47 & 2.31 & 1.97 & 1.9 & 2.52 & 2.35 & 1.14 & 1.9 & 2.11 \\
\hline $\mathrm{TiO} 2$ & 0.33 & 0.52 & 0.36 & 0.57 & 0.29 & 0.48 & 0.24 & 0.29 & 0.34 \\
\hline $\mathrm{P} 2 \mathrm{O} 5$ & 0.12 & 0.19 & 0.04 & 0.14 & 0.04 & 0.01 & 0.06 & 0.09 & 0.21 \\
\hline $\mathrm{MnO}$ & 0.05 & 0.05 & 0.1 & 0.06 & 0.03 & 0.09 & 0.03 & 0.13 & 0.04 \\
\hline $\mathrm{Cr}$ & 0.003 & $<0.002$ & 0.004 & 0.004 & $<0.002$ & 0.008 & $<0.002$ & $<0.002$ & $<0.002$ \\
\hline LOI & 1.5 & 1.6 & 0.3 & 0.9 & 1.4 & 1.1 & 0.8 & 10 & 1.8 \\
\hline TOTAL & 99.63 & 99.65 & 99.83 & 99.84 & 99.92 & 99.89 & 99.87 & 99.84 & 99.62 \\
\hline Ba ppm & 871 & 778 & 490 & 581 & 359 & 414 & 380 & 288 & 913 \\
\hline Cs & 0.4 & 1.4 & 3.3 & 7.7 & 3.6 & 3.4 & $<0.1$ & 0.7 & 1.7 \\
\hline $\mathrm{Ga}$ & 19.2 & 18 & 17.2 & 17.9 & 12.3 & 12.2 & 16.9 & 12.7 & 16 \\
\hline Hf & 5.3 & 4.2 & 8.7 & 4.8 & 2.5 & 5.3 & 2.7 & 3 & 7.2 \\
\hline $\mathrm{Nb}$ & 5.1 & 6.9 & 5.6 & 7.6 & 6.4 & 4.8 & 3.2 & 4.8 & 4.5 \\
\hline $\mathrm{Rb}$ & 33.2 & 72.4 & 110.6 & 107.3 & 100.9 & 100.7 & 31.3 & 71.7 & 70.1 \\
\hline $\mathrm{Sr}$ & 747.8 & 698.5 & 239.9 & 239.8 & 70.6 & 147.7 & 532.3 & 144.7 & 209.9 \\
\hline $\mathrm{Ta}$ & 0.5 & 0.8 & 0.2 & 0.7 & 0.8 & 0.3 & 0.2 & 0.3 & 0.4 \\
\hline Th & 5.6 & 9.7 & 13.9 & 3.7 & 5.5 & 5.9 & 2.3 & 2 & 40.9 \\
\hline $\mathrm{U}$ & 1.2 & 3.6 & 1.3 & 0.9 & 2.3 & 1.6 & 0.3 & 0.3 & 1.9 \\
\hline $\mathrm{Sc}$ & 3 & 7 & 12 & 12 & 6 & 9 & 4 & 6 & 5 \\
\hline V & 46 & 61 & 55 & 49 & 33 & 64 & 25 & 40 & 25 \\
\hline $\mathrm{Zr}$ & 197 & 163.6 & 326.3 & 179.2 & 89.5 & 185.7 & 106.3 & 106.4 & 294.8 \\
\hline$Y$ & 14.5 & 11.3 & 29.4 & 8 & 19.8 & 14.5 & 2.7 & 4.9 & 14.9 \\
\hline $\mathrm{Cu}$ & 6.8 & 10.7 & 36.8 & 6.5 & 12.4 & 61.3 & 4.3 & 11.8 & 42.7 \\
\hline $\mathrm{Pb}$ & 1.9 & 3.1 & 3.9 & 6.4 & 27.4 & 4.4 & 2.9 & 3.3 & 5 \\
\hline $\mathrm{Zn}$ & 35 & 61 & 53 & 81 & 44 & 50 & 38 & 52 & 42 \\
\hline $\mathrm{Ni}$ & 2.5 & 11.1 & 17.7 & 22.2 & 7 & 39.6 & 3.4 & 6.4 & 4.7 \\
\hline La ppm & 40.7 & 34.5 & 45.9 & 16.1 & 14.1 & 22.4 & 11.9 & 12.3 & 147.2 \\
\hline $\mathrm{Ce}$ & 73.6 & 73.8 & 89.7 & 39.9 & 17.7 & 44.1 & 24.6 & 23.6 & 276.7 \\
\hline $\operatorname{Pr}$ & 9.01 & 8.73 & 9.58 & 3.93 & 3.56 & 4.63 & 2.45 & 2.77 & 31.13 \\
\hline $\mathrm{Nd}$ & 33.3 & 34.2 & 35.2 & 14.3 & 13.1 & 16.8 & 8.5 & 11.4 & 107.6 \\
\hline $\mathrm{Sm}$ & 5.8 & 4.93 & 6.02 & 2.71 & 3.13 & 3.02 & 1.5 & 1.99 & 13.65 \\
\hline $\mathrm{Eu}$ & 1.62 & 1.46 & 1.42 & 1.12 & 0.46 & 0.46 & 0.7 & 0.39 & 1.29 \\
\hline $\mathrm{Gd}$ & 4.73 & 3.97 & 5.01 & 2.17 & 3.39 & 2.41 & 1.06 & 1.66 & 8.1 \\
\hline $\mathrm{Tb}$ & 0.59 & 0.49 & 0.76 & 0.32 & 0.54 & 0.36 & 0.13 & 0.19 & 0.82 \\
\hline Dy & 3.06 & 2.48 & 4.83 & 1.56 & 3.39 & 2.16 & 0.51 & 0.95 & 3.75 \\
\hline Ho & 0.51 & 0.47 & 1.25 & 0.35 & 0.76 & 0.64 & 0.1 & 0.17 & 0.53 \\
\hline $\mathrm{Er}$ & 1.32 & 1.27 & 3.79 & 0.89 & 2.26 & 1.98 & 0.27 & 0.45 & 1.16 \\
\hline $\mathrm{Tm}$ & 0.17 & 0.21 & 0.62 & 0.14 & 0.34 & 0.32 & 0.04 & 0.08 & 0.16 \\
\hline $\mathrm{Yb}$ & 0.96 & 1.4 & 4.07 & 0.75 & 2.02 & 2.27 & 0.23 & 0.44 & 0.84 \\
\hline $\mathrm{Lu}$ & 0.16 & 0.21 & 0.62 & 0.13 & 0.29 & 0.32 & 0.04 & 0.08 & 0.12 \\
\hline
\end{tabular}


4. Evolução crustal riaciana do embasamento paleoproterozóico da Faixa Brasília

Table 4.5: Whole rock chemistry results from Natividade basement (3/4).

\begin{tabular}{|c|c|c|c|c|c|c|c|c|c|}
\hline & NI-V- & NI-V- & NI-V- & NI-VII- & & & NI-VII- & & \\
\hline & $93 \mathrm{~A}$ & $96 \mathrm{C}$ & $118 \mathrm{~A}$ & 32 & PI 15 & PI 18 & 38 & NI-I-50 & NI-I-74 \\
\hline Unit & MA & MA & MA & MA & CQ & CQ & CQ & XS & XS \\
\hline $\mathrm{SiO} 2 \%$ & 73.41 & 71.32 & 68.17 & 70.17 & 71.46 & 72.6 & 70.15 & 74.13 & 71.73 \\
\hline $\mathrm{Al} 2 \mathrm{O} 3$ & 13.39 & 14.66 & 14.52 & 14.68 & 15.46 & 14.48 & 15.7 & 14.59 & 15.02 \\
\hline $\mathrm{Fe} 2 \mathrm{O} 3$ & 2.35 & 2.55 & 4.13 & 4.17 & 2.35 & 2.42 & 2.72 & 0.75 & 0.06 \\
\hline $\mathrm{MgO}$ & 0.74 & 0.69 & 1.74 & 1.21 & 0.79 & 0.6 & 1.02 & 0.11 & $<0.01$ \\
\hline $\mathrm{CaO}$ & 3.46 & 3.47 & 3.3 & 3.39 & 2.99 & 2.17 & 3.36 & 0.72 & 0.13 \\
\hline $\mathrm{Na} 2 \mathrm{O}$ & 3.49 & 3.7 & 3.51 & 3.35 & 4.65 & 3.85 & 4.21 & 3.82 & 2 \\
\hline $\mathrm{K} 2 \mathrm{O}$ & 0.94 & 1.51 & 2.44 & 1.55 & 1.3 & 2.92 & 1.5 & 4.11 & 10.25 \\
\hline $\mathrm{TiO} 2$ & 0.29 & 0.29 & 0.48 & 0.49 & 0.23 & 0.26 & 0.26 & 0.04 & $<0.01$ \\
\hline P2O5 & 0.05 & 0.11 & 0.12 & 0.06 & 0.05 & 0.05 & 0.09 & 0.15 & 0.06 \\
\hline $\mathrm{MnO}$ & 0.03 & 0.03 & 0.07 & 0.05 & 0.06 & 0.03 & 0.05 & 0.02 & $<0.01$ \\
\hline $\mathrm{Cr}$ & 0.003 & $<0.002$ & 0.007 & 0.005 & $<0.002$ & $<0.002$ & $<0.002$ & $<0.002$ & $<0.002$ \\
\hline LOI & 1.5 & 1.3 & 1.3 & 0.6 & 0.6 & 0.5 & 0.7 & 1.3 & 0.6 \\
\hline TOTAL & 99.63 & 99.65 & 99.75 & 99.75 & 99.93 & 99.89 & 99.77 & 99.72 & 99.86 \\
\hline $\mathrm{Ba} \mathrm{ppm}$ & 370 & 374 & 266 & 543 & 157 & 483 & 182 & 185 & 69 \\
\hline Cs & 0.3 & 1.2 & 6.8 & 6.5 & 15.5 & 3 & 8.3 & 4.8 & 3.1 \\
\hline $\mathrm{Ga}$ & 15.9 & 17.3 & 19 & 18.8 & 18.7 & 18.2 & 19.8 & 24.9 & 12.5 \\
\hline Hf & 2.1 & 4.2 & 4.4 & 4.3 & 3.1 & 3.9 & 2.3 & 3.6 & 0.2 \\
\hline $\mathrm{Nb}$ & 3.2 & 4.2 & 8.4 & 7.1 & 6.5 & 8.6 & 6.9 & 9.5 & 0.9 \\
\hline $\mathrm{Rb}$ & 27.4 & 49.6 & 115.7 & 96 & 79.2 & 116.9 & 95.4 & 222.9 & 368.8 \\
\hline $\mathrm{Sr}$ & 316.3 & 345.6 & 240.6 & 251.4 & 271.2 & 214.3 & 321.1 & 43.4 & 35.3 \\
\hline $\mathrm{Ta}$ & 0.6 & 0.7 & 1.5 & 0.7 & 1.3 & 1 & 1 & 1.4 & 0.2 \\
\hline Th & 5.5 & 5.2 & 9 & 14.3 & 4.8 & 9.6 & 3.3 & 12.5 & 0.5 \\
\hline $\mathrm{U}$ & 0.2 & 0.4 & 4 & 0.9 & 2.1 & 4 & 1.3 & 25.5 & 2.4 \\
\hline $\mathrm{Sc}$ & 4 & 5 & 12 & 10 & 5 & 6 & 6 & 3 & $<1$ \\
\hline $\mathrm{V}$ & 39 & 29 & 63 & 46 & 26 & 18 & 39 & 9 & $<8$ \\
\hline $\mathrm{Zr}$ & 73.9 & 162.6 & 145.3 & 150.7 & 95.7 & 129.5 & 83.7 & 88.1 & 4.2 \\
\hline $\mathrm{Y}$ & 2.4 & 5.7 & 14 & 6.1 & 10.4 & 8.6 & 7.4 & 13 & 6.9 \\
\hline $\mathrm{Cu}$ & 24.7 & 6.8 & 2 & 5.4 & 4.8 & 8.2 & 12.5 & 20.2 & 0.2 \\
\hline $\mathrm{Pb}$ & 1.5 & 2.1 & 3.6 & 3.2 & 4.2 & 3.9 & 1.4 & 3.3 & 2.8 \\
\hline $\mathrm{Zn}$ & 26 & 31 & 63 & 61 & 36 & 43 & 53 & 30 & $<1$ \\
\hline $\mathrm{Ni}$ & 6.4 & 2.5 & 18.2 & 18.6 & 5.7 & 6.6 & 7 & 0.6 & 0.2 \\
\hline La ppm & 25.9 & 22.3 & 23.3 & 31.5 & 11.5 & 19.9 & 14 & 17.1 & 1.5 \\
\hline $\mathrm{Ce}$ & 53.8 & 41.5 & 41 & 80.8 & 23.8 & 51.6 & 25.4 & 34.3 & 2 \\
\hline $\operatorname{Pr}$ & 5.5 & 4.86 & 4.78 & 7.3 & 2.66 & 4.77 & 3.18 & 3.99 & 0.32 \\
\hline $\mathrm{Nd}$ & 19.4 & 17.2 & 18.3 & 24.7 & 10.3 & 16.9 & 11.1 & 13.5 & 1.3 \\
\hline $\mathrm{Sm}$ & 2.51 & 2.74 & 3.3 & 3.94 & 2.18 & 3.18 & 2.08 & 3.32 & 0.37 \\
\hline $\mathrm{Eu}$ & 0.76 & 0.95 & 0.83 & 1.37 & 0.46 & 0.56 & 0.58 & 0.17 & 0.09 \\
\hline Gd & 1.64 & 2.05 & 2.98 & 2.76 & 2.17 & 2.78 & 1.8 & 3.11 & 0.72 \\
\hline $\mathrm{Tb}$ & 0.15 & 0.23 & 0.4 & 0.32 & 0.37 & 0.39 & 0.25 & 0.49 & 0.17 \\
\hline Dy & 0.61 & 1.14 & 2.47 & 1.56 & 1.91 & 1.95 & 1.53 & 2.83 & 1.05 \\
\hline Ho & 0.1 & 0.22 & 0.48 & 0.21 & 0.41 & 0.41 & 0.26 & 0.37 & 0.18 \\
\hline $\mathrm{Er}$ & 0.2 & 0.53 & 1.33 & 0.47 & 1.05 & 1.26 & 0.74 & 0.91 & 0.54 \\
\hline $\mathrm{Tm}$ & 0.03 & 0.09 & 0.21 & 0.07 & 0.17 & 0.18 & 0.1 & 0.13 & 0.07 \\
\hline $\mathrm{Yb}$ & 0.09 & 0.47 & 1.39 & 0.46 & 1.3 & 1.29 & 0.6 & 0.82 & 0.42 \\
\hline $\mathrm{Lu}$ & 0.02 & 0.09 & 0.22 & 0.05 & 0.18 & 0.17 & 0.09 & 0.1 & 0.06 \\
\hline
\end{tabular}


4. Evolução crustal riaciana do embasamento paleoproterozóico da Faixa Brasília

Table 4.6: Whole rock chemistry results from Natividade basement (4/4).

\begin{tabular}{|c|c|c|c|c|c|c|c|}
\hline Unit & $\begin{array}{r}\text { PR-IX- } \\
104 \\
\text { GP }\end{array}$ & $\begin{array}{r}\text { PR-IX-52 } \\
\text { GP }\end{array}$ & $\begin{array}{r}\text { PR-PTF- } \\
\text { ALMEIDAO } \\
\text { GP }\end{array}$ & $\begin{array}{r}\text { PR-PTF- } \\
\text { ALMEIDINHA } \\
\text { GP }\end{array}$ & $\begin{array}{r}\text { PR-X-69 } \\
\text { GP }\end{array}$ & $\begin{array}{r}\text { PR-M-8 } \\
\text { GP }\end{array}$ & $\begin{array}{r}\text { PR-M-9 } \\
\text { GP }\end{array}$ \\
\hline $\mathrm{SiO} 2 \%$ & 72.5 & 73.73 & 72.07 & 74.02 & 72.3 & 70.93 & 76.3 \\
\hline $\mathrm{Al} 2 \mathrm{O} 3$ & 14.38 & 13.97 & 14.06 & 13.23 & 14.19 & 14.33 & 12.23 \\
\hline $\mathrm{Fe} 2 \mathrm{O} 3$ & 1.9 & 1.45 & 2.32 & 1.91 & 1.8 & 2.63 & 1.37 \\
\hline $\mathrm{MgO}$ & 0.37 & 0.55 & 0.48 & 0.37 & 0.37 & 0.56 & 0.32 \\
\hline $\mathrm{CaO}$ & 0.71 & 0.24 & 0.95 & 1.2 & 1.04 & 1.15 & 1.02 \\
\hline $\mathrm{Na} 2 \mathrm{O}$ & 3.22 & 3.12 & 3.04 & 4.14 & 3.15 & 2.89 & 3.54 \\
\hline $\mathrm{K} 2 \mathrm{O}$ & 5.37 & 4.96 & 5.3 & 3.38 & 5.43 & 5.39 & 3.71 \\
\hline $\mathrm{TiO} 2$ & 0.28 & 0.13 & 0.28 & 0.19 & 0.24 & 0.37 & 0.17 \\
\hline P2O5 & 0.21 & 0.04 & 0.14 & 0.07 & 0.1 & 0.24 & 0.03 \\
\hline $\mathrm{MnO}$ & 0.03 & 0.02 & 0.03 & 0.03 & 0.02 & 0.02 & 0.02 \\
\hline $\mathrm{Cr}$ & $<0.002$ & $<0.002$ & $<0.002$ & $<0.002$ & $<0.002$ & $<0.002$ & $<0.002$ \\
\hline LOI & 0.8 & 1.5 & 1 & 1.2 & 1.1 & 1.2 & 1.1 \\
\hline TOTAL & 99.79 & 99.75 & 99.67 & 99.69 & 99.78 & 99.69 & 99.81 \\
\hline $\mathrm{Ba}$ ppm & 523 & 465 & 902 & 748 & 784 & 807 & 417 \\
\hline $\mathrm{Cs}$ & 7.3 & 5.7 & 1.9 & 1.7 & 5.4 & 1.4 & 2.2 \\
\hline $\mathrm{Ga}$ & 27.3 & 25.6 & 22.3 & 18.1 & 21 & 21.2 & 16.2 \\
\hline Hf & 5.8 & 3.5 & 5.7 & 5 & 5 & 7 & 5.2 \\
\hline $\mathrm{Nb}$ & 12.8 & 13.7 & 12.8 & 14.3 & 8.2 & 9.4 & 6.2 \\
\hline $\mathrm{Rb}$ & 399.5 & 395.6 & 278.8 & 119.7 & 286.7 & 263.7 & 169.3 \\
\hline $\mathrm{Sr}$ & 86.8 & 55 & 155.2 & 154.6 & 134.2 & 166 & 185.4 \\
\hline $\mathrm{Ta}$ & 1.4 & 1.8 & 0.9 & 1.6 & 0.8 & 0.5 & 0.9 \\
\hline $\mathrm{Th}$ & 52.5 & 31.4 & 56 & 16.3 & 49.5 & 63.8 & 46 \\
\hline $\mathrm{U}$ & 11.7 & 6.8 & 3.5 & 2.7 & 4.3 & 3.7 & 9 \\
\hline $\mathrm{Sc}$ & 3 & 3 & 5 & 4 & 3 & 4 & 3 \\
\hline V & 29 & 20 & 22 & 16 & 15 & 30 & 11 \\
\hline $\mathrm{Zr}$ & 185 & 109.1 & 214.3 & 149.8 & 172.6 & 260.5 & 163.1 \\
\hline $\mathrm{Y}$ & 14.7 & 17.9 & 16.7 & 42 & 9 & 6.9 & 4.7 \\
\hline $\mathrm{Cu}$ & 7.3 & 0.5 & 6 & 3.6 & 0.2 & 8.2 & 0.8 \\
\hline $\mathrm{Pb}$ & 8.1 & 3.4 & 12.2 & 6.8 & 8.1 & 10.2 & 6.5 \\
\hline $\mathrm{Zn}$ & 69 & 47 & 80 & 63 & 51 & 94 & 38 \\
\hline $\mathrm{Ni}$ & 2 & 1.4 & 2.6 & 2.2 & 2.1 & 3.7 & 1.4 \\
\hline La ppm & 97.2 & 46.2 & 90.3 & 57.9 & 66.2 & 42 & 52 \\
\hline $\mathrm{Ce}$ & 180.3 & 37 & 167.1 & 82.8 & 140.1 & 140.6 & 121.6 \\
\hline $\operatorname{Pr}$ & 23.58 & 8.31 & 17.74 & 10.42 & 14.7 & 10.04 & 12.39 \\
\hline $\mathrm{Nd}$ & 83.5 & 27.4 & 58.4 & 35.6 & 50 & 34.4 & 44 \\
\hline $\mathrm{Sm}$ & 12.48 & 4.76 & 8.28 & 6.77 & 7.58 & 6.47 & 6.99 \\
\hline $\mathrm{Eu}$ & 0.68 & 0.48 & 0.65 & 0.8 & 0.58 & 0.43 & 0.51 \\
\hline $\mathrm{Gd}$ & 6.52 & 4.06 & 5.12 & 6.96 & 4.17 & 3.96 & 4.4 \\
\hline $\mathrm{Tb}$ & 0.65 & 0.56 & 0.59 & 1.06 & 0.42 & 0.39 & 0.37 \\
\hline Dy & 2.87 & 2.98 & 2.9 & 6.2 & 1.86 & 1.68 & 1.47 \\
\hline Ho & 0.43 & 0.51 & 0.56 & 1.27 & 0.27 & 0.27 & 0.18 \\
\hline $\mathrm{Er}$ & 0.96 & 1.45 & 1.53 & 3.62 & 0.75 & 0.67 & 0.48 \\
\hline $\mathrm{Tm}$ & 0.15 & 0.2 & 0.21 & 0.56 & 0.1 & 0.1 & 0.07 \\
\hline $\mathrm{Yb}$ & 0.92 & 1.28 & 1.14 & 3.12 & 0.81 & 0.64 & 0.45 \\
\hline $\mathrm{Lu}$ & 0.14 & 0.19 & 0.16 & 0.44 & 0.1 & 0.1 & 0.07 \\
\hline
\end{tabular}


Table 4.7: Sm-Nd isotopic data for Natividade basement.

\begin{tabular}{|c|c|c|c|c|c|c|c|}
\hline Sample & Unit & $\mathrm{Sm}(\mathrm{ppm})$ & $\mathrm{Nd}(\mathrm{ppm})$ & ${ }^{147} \mathrm{Sm} /{ }^{144} \mathrm{Nd}$ & $\begin{array}{c}{ }^{143} \mathrm{Nd} /{ }^{144} \mathrm{Nd} \\
\pm 2 \mathrm{SE}\end{array}$ & $\mathrm{e}_{\mathrm{Nd}(0)}$ & $\begin{array}{l}\mathrm{T}_{\mathrm{DM}} \\
(\mathrm{Ga})\end{array}$ \\
\hline NI-V 93A & MA & 2.609 & 18.624 & 0.0847 & $0.510983+/-6$ & -32.275 & 2.42 \\
\hline NI-V 87A & MA & 6.716 & 47.854 & 0.0848 & $0.51107+/-13$ & -30.591 & 2.32 \\
\hline NI-V 95A & MA & 13.528 & 106.244 & 0.0770 & $0.510874+/-11$ & -34.403 & 2.41 \\
\hline NI-V-118A & MA & 7.515 & 39.578 & 0.1148 & $0.511529+/-19$ & -21.634 & 2.32 \\
\hline NI-VIII 32 & MA & 3.920 & 24.090 & 0.0984 & $0.511327+/-579$ & -25.573 & 2.26 \\
\hline NI-VII 38 & MA & 1.857 & 9.516 & 0.1180 & $0.511528+/-19$ & -21.644 & 2.4 \\
\hline NI-V-96C & MA & 2.986 & 18.658 & 0.0967 & $0.51127+/-18$ & -26.676 & 2.3 \\
\hline NI-V-86A & MA & 1.847 & 10.260 & 0.1088 & $0.511345+/-2$ & -25.221 & 2.46 \\
\hline PI10 & MA & 2.946 & 15.407 & 0.1156 & $0.511334+/-20$ & -25.430 & 2.65 \\
\hline PI9MA & MA & 6.134 & 36.072 & 0.1028 & $0.511217+/-17$ & -27.720 & 2.5 \\
\hline PI15 & MA & 2.296 & 10.213 & 0.1359 & $0.511761+/-16$ & -17.100 & 2.51 \\
\hline PI18 & MA & 3.334 & 17.482 & 0.1153 & $0.511503+/-5$ & -22.140 & 2.38 \\
\hline PI20 & MA & 3.119 & 14.366 & 0.1312 & $0.511528+/-17$ & -21.650 & 2.81 \\
\hline PI35 & MA & 3.006 & 17.243 & 0.1054 & $0.511299+/-15$ & -26.110 & 2.45 \\
\hline PI42 & MA & 1.400 & 8.964 & 0.0944 & $0.510610+/-1$ & -39.560 & 3.12 \\
\hline PR-PTF-PP & PG & 7.311 & 35.223 & 0.1255 & $0.511513+/-3$ & -21.938 & 2.64 \\
\hline PR IX 104 & PG & 14.330 & 97.146 & 0.0892 & $0.511117+/-10$ & -29.671 & 2.35 \\
\hline PRX69 & $\mathrm{PG}$ & 7.484 & 47.352 & 0.0955 & $0.511121+/-18$ & -29.592 & 2.47 \\
\hline PR-PTF-P & PG & 8.602 & 59.812 & 0.0869 & $0.511087+/-16$ & -30.264 & 2.34 \\
\hline PR IX 52 & $\mathrm{PG}$ & 5.383 & 28.337 & 0.1148 & $0.511377+/-10$ & -24.591 & 2.56 \\
\hline PRM8 & PG & 6.181 & 35.029 & 0.1067 & $0.511124+/-9$ & -29.530 & 2.73 \\
\hline PRM9 & PG & 7.411 & 43.629 & 0.1027 & $0.511117+/-15$ & -29.670 & 2.64 \\
\hline NI-VIII 122 & RM & 6.140 & 47.197 & 0.0786 & $0.510913+/-20$ & -33.643 & 2.39 \\
\hline PR-X-80 & RM & 4.421 & 28.426 & 0.0940 & $0.511065+/-16$ & -30.678 & 2.51 \\
\hline NI-VIII 164F & RM & 6.536 & 29.962 & 0.1319 & $0.511675+/-12$ & -18.783 & 2.54 \\
\hline NI-X-22 & $\mathrm{RM}$ & 10.822 & 60.618 & 0.1079 & $0.511298+/-17$ & -26.132 & 2.51 \\
\hline PRX60 & RM & 5.935 & 35.933 & 0.0998 & $0.511212+/-15$ & -27.817 & 2.44 \\
\hline NI-VIII 164G & RM & 5.655 & 31.099 & 0.1099 & $0.511355+/-12$ & -25.022 & 2.47 \\
\hline PI2 & $\mathrm{RM}$ & 3.266 & 22.534 & 0.0876 & $0.511035+/-18$ & -31.270 & 2.42 \\
\hline PI3 & $\mathrm{RM}$ & 9.314 & 59.229 & 0.0951 & $0.511114+/-11$ & -29.740 & 2.47 \\
\hline PI25 & $\mathrm{RM}$ & 5.304 & 36.049 & 0.0889 & $0.511053+/-16$ & -30.910 & 2.42 \\
\hline PRM3 & $\mathrm{RM}$ & 6.136 & 38.841 & 0.0955 & $0.511107+/-16$ & -29.860 & 2.49 \\
\hline PRM5A & $\mathrm{RM}$ & 5.583 & 33.295 & 0.1014 & $0.511204+/-19$ & -27.980 & 2.49 \\
\hline PRM5B & $\mathrm{RM}$ & 4.931 & 29.907 & 0.0997 & $0.511187+/-22$ & -28.310 & 2.47 \\
\hline PRM5C & $\mathrm{RM}$ & 9.181 & 54.844 & 0.1012 & $0.511133+/-7$ & -29.350 & 2.58 \\
\hline NI-I 50 & $\mathrm{XS}$ & 3.240 & 13.073 & 0.1498 & $0.51187+/-12$ & -14.974 & 2.81 \\
\hline
\end{tabular}


Table 4.8: Coordinates from samples used in this project.

\begin{tabular}{|c|c|c|c|c|c|c|c|c|c|}
\hline \multirow{2}{*}{$\begin{array}{l}\text { Sample } \\
\text { G1 }\end{array}$} & \multicolumn{2}{|c|}{ Datum } & \multirow{2}{*}{$\begin{array}{r}E \\
224268\end{array}$} & \multirow{2}{*}{$\begin{array}{r}\mathrm{N} \\
8672224\end{array}$} & \multirow{2}{*}{$\begin{array}{l}\text { Sample } \\
\text { PI } 4\end{array}$} & \multicolumn{2}{|c|}{ Datum } & \multirow{2}{*}{$\begin{array}{r}E \\
215366\end{array}$} & \multirow{2}{*}{$\begin{array}{r}\mathrm{N} \\
8681476\end{array}$} \\
\hline & WGS84 & $23 \mathrm{~S}$ & & & & WGS84 & $23 \mathrm{~S}$ & & \\
\hline G2 & WGS84 & $23 \mathrm{~S}$ & 221606 & 8668946 & PI 9MA & WGS84 & $23 \mathrm{~S}$ & 196846 & 8679232 \\
\hline G3 & WGS84 & $23 \mathrm{~S}$ & 215335 & 8681478 & PI 10 & WGS84 & $23 \mathrm{~S}$ & 197414 & 8679092 \\
\hline G7 & WGS84 & $23 \mathrm{~S}$ & 192725 & 8682152 & PI 15 & WGS84 & $23 \mathrm{~S}$ & 192235 & 8679306 \\
\hline $\begin{array}{l}\text { PR-PTF- } \\
\text { ALMEIDAO }\end{array}$ & WGS84 & $23 \mathrm{~S}$ & 221500 & 8668900 & PI 18 & WGS84 & $23 \mathrm{~S}$ & 191055 & 8677022 \\
\hline $\begin{array}{l}\text { PR-PTF- } \\
\text { ALMEIDINHA }\end{array}$ & WGS84 & $23 \mathrm{~S}$ & 224301 & 8672294 & PI 19 & WGS84 & $23 \mathrm{~S}$ & 194714 & 8681124 \\
\hline PR-X-27 & WGS84 & $23 \mathrm{~S}$ & 226280 & 8672832 & PI 20 & WGS84 & $23 \mathrm{~S}$ & 202206 & 8697732 \\
\hline PR-X-69 & WGS84 & $23 \mathrm{~S}$ & 219395 & 8674262 & PI 25 & WGS84 & $23 \mathrm{~S}$ & 232760 & 8647139 \\
\hline PR-M-8 & WGS84 & $23 \mathrm{~S}$ & 224631 & 8648164 & PI 26 & WGS84 & $23 \mathrm{~S}$ & 225904 & 8648878 \\
\hline PR-M-9 & WGS84 & $23 \mathrm{~S}$ & 221733 & 8646539 & PI 35 & WGS84 & $23 \mathrm{~S}$ & 201627 & 8633189 \\
\hline PR-X-66 & WGS84 & $23 \mathrm{~S}$ & 220399 & 8667640 & PI 40 & WGS84 & $23 \mathrm{~S}$ & 235586 & 8659981 \\
\hline PR-X-74 & WGS84 & $23 \mathrm{~S}$ & 216416 & 8675324 & PI 41 & WGS84 & $23 \mathrm{~S}$ & 235913 & 8659111 \\
\hline PR-M-11 & WGS84 & $23 \mathrm{~S}$ & 217460 & 8630849 & PI 42 & WGS84 & $23 \mathrm{~S}$ & 200409 & 8656950 \\
\hline PR-M-13B & WGS84 & $23 \mathrm{~S}$ & 217786 & 8628283 & NI-VIII-122 & WGS84 & $23 \mathrm{~S}$ & 228801 & 8685004 \\
\hline PR-X-64 & WGS84 & $23 \mathrm{~S}$ & 221837 & 8669104 & NI-IX-44 & WGS84 & $23 \mathrm{~S}$ & 211095 & 8669166 \\
\hline PR-X-80 & WGS84 & $23 \mathrm{~S}$ & 215789 & 8679834 & NI-X-22 & WGS84 & $23 \mathrm{~S}$ & 222037 & 8678084 \\
\hline PR-X-60 & WGS84 & $23 \mathrm{~S}$ & 215577 & 8679826 & NI-VIII-164F & WGS84 & $23 \mathrm{~S}$ & 219438 & 8682874 \\
\hline PR-VIII-56 & WGS84 & $23 \mathrm{~S}$ & 219361 & 8688658 & NI-VIII-164G & WGS84 & $23 \mathrm{~S}$ & 219438 & 8682874 \\
\hline PR-M-1 & WGS84 & $23 \mathrm{~S}$ & 215444 & 8690301 & NI-V-86A & WGS84 & $23 \mathrm{~S}$ & 204830 & 8688808 \\
\hline PR-M-3 & WGS84 & $23 \mathrm{~S}$ & 215358 & 8681474 & NI-V-95A & WGS84 & $23 \mathrm{~S}$ & 206466 & 8688850 \\
\hline PR-M-4B & WGS84 & $23 \mathrm{~S}$ & 200117 & 8714137 & NI-V-106 & WGS84 & $23 \mathrm{~S}$ & 207717 & 8688678 \\
\hline PR-M-5A & WGS84 & $23 \mathrm{~S}$ & 215590 & 8680002 & NI-V-93A & WGS84 & $23 \mathrm{~S}$ & 206671 & 8688802 \\
\hline PR-M-5B & WGS84 & $23 \mathrm{~S}$ & 215590 & 8680002 & NI-V-96C & WGS84 & $23 \mathrm{~S}$ & 206063 & 8688914 \\
\hline PR-M-5c & WGS84 & $23 \mathrm{~S}$ & 215590 & 8680002 & NI-V-87A & WGS84 & $23 \mathrm{~S}$ & 204196 & 8688546 \\
\hline PR-M-15 & WGS84 & $23 \mathrm{~S}$ & 217016 & 8685029 & NI-V-118A & WGS84 & $23 \mathrm{~S}$ & 197378 & 8694076 \\
\hline PR-M-4A & WGS84 & $23 \mathrm{~S}$ & 200117 & 8714137 & NI-V-20C & WGS84 & $23 \mathrm{~S}$ & 194318 & 8691884 \\
\hline PR-M-13A & WGS84 & $23 \mathrm{~S}$ & 217786 & 8628283 & NI-I-50 & WGS84 & $23 \mathrm{~S}$ & 196604 & 8707264 \\
\hline PI 2 & WGS84 & $23 \mathrm{~S}$ & 215444 & 8690301 & NI-I-74 & WGS84 & $23 \mathrm{~S}$ & 195931 & 8712696 \\
\hline PI 3 & WGS84 & $23 \mathrm{~S}$ & 217029 & 8686770 & NI-VII-32 & WGS84 & $23 \mathrm{~S}$ & 197426 & 8679098 \\
\hline NI-VII-38 & WGS84 & $23 \mathrm{~S}$ & 193358 & 8684094 & & & & & \\
\hline
\end{tabular}




\section{CONCLUSÕeS}

Os dados apresentados na presente dissertação englobam uma parte significativa do embasamento da Faixa Brasília. Foram reunidos resultados apresentados por Cruz (2003), Botelho et al., (2006) e dados inéditos na tentativa de caracterizar como se deu a evolução do embasamento granítico.

Os resultados sugerem uma evolução de arco calcialcalino que culmina com a intrusão de granitos tipo S, durante uma fase de colisão. Sugerimos que o arco tenha se desenvolvido na margem do cráton São Francisco e que os granitos sin-colisionais sejam decorrentes da colisão de um micro-continente com o cráton.

Para hierarquizar as unidades geológicas do embasamento, sugerimos nomear as unidades de arco magmático calcialcalino de suíte Conceição do Tocantins e classificar as unidades sin-colisionais como suíte Aurumina, nomenclatura já utilizada na literatura (Botelho et al., 2006).

A evolução geológica paleoproterozóica é complexa, de difícil interpretação e estudos futuros são necessários para compreendê-la. Projetos futuros devem priorizar o mapeamento geológico e investigar se existe algum indicativo de sutura paleoproterozóica.

A correlação da suíte Conceição do Tocantins com a suíte Pau de Mel é especialmente interessante porque tem implicações na evolução neoproterozóica da Faixa Brasília. As semelhanças entreas duas suítes indicam que o embasamento do maciço de Goiás e da Faixa Brasília são possivelmente equivalentes. Consequentemente, o caráter alóctone do maciço passa a ser questionado. É possível que as suítes Pau de Mel, Jurubatuba e Conceição do Tocantins tenham se desenvolvido contemporaneamente e representem um magmatismo de arco na borda do cráton São Francisco. Por essa interpretação, a paleoplaca São Francisco se estende por baixo dos sedimentos da faixa Brasília até o limite com o Arco Magmático de Goiás.

Futuros projetos devem verificar se existe a possibilidade do núcleo arqueano do Maciço de Goiás ser o bloco siálico cuja aproximação desencadeou o magmatismo de arco na borda do cráton São Francisco. 


\section{REFERÊNCIAS BIBLIOGRÁFICAS}

Almeida, F. F. M., Hasui, Y., Brito Neves, B. B. \& Fuck, R. A. 1981. Brazilian structural provinces: an introduction. Earth-Science Reviews, 17, 1-29.

Alvarenga, C.J.S., Dardenne, M.A., Botelho, N.F., Lima, O.N.B., Machado, M.A., Almeida, T., 2007. Nota Explicativa das folhas SD.23-V-C-III (Monte alegre de Goiás), SD.23-V-C-V (Cavalcante) , SD.23-V-C-VI (Nova Roma). CPRM, 2007. 65 pp.

Alvarenga, C.J.S. , Dardenne, M.A., Vieira, L. C., Martinho, C. T., Guimarães, E. M., Santos, R.V., Santana, R.O. Estratigrafia da borda ocidental da Bacia do São Francisco. Boletim de Geociências da PETROBRAS (Impresso), v. 20, p. 145-164, 2012.

Araújo-Filho, J.O. 2000. The Pireneus Syntaxis: an example of the intersection of two Brasiliano fold-thrust belts in central Brazil and its implications for the tectonic evolution of western Gondwana. Rev. Bras. Geocienc. 30:144-148.

Arcanjo, S.H.S., Abreu, F.A.M., Moura, C.A.V. Evolução geológica das sequências do embasamento do Cinturão Araguaia na região de Paraíso do Tocantins (TO), Brasil. Brazilian Journal of Geology, v. 43, p. 501$514,2013$.

Anderson, J. L. 1980. Mineral equilibria and crystallization is the late Precambrian Wolf River rapakivi massif, Wisconsin: America Journal os Science, v. 280, p. 289-332.

Anderson, J.L., Rowley, M.C. 1980. Anorogenic metaluminous and peraluminous granite plutonism in the midProterozoic of Wisconsin, U.S.A.: Contributions to Mineralogy and Petrology, v. 74, p. 311-328.

Anderson, J.L., Rowley, M.C. 1981. Synkinematic intrusion of two-mica and associated metaluminous granitoids, Whipple Mountains, California: Candian Mineralogist, v. 19, p.83-101.

Arndt, N.T., Teixeira, N.A., White, W.M, 1989. Bizarre geochemistry of komatiites from the Crixás Greenstone Belt. Contr. Mineral. Petrol., 101:187-197.

Batchelor, R. A. \& Bowden, P. (1985). Petrogenetic interpretation of granitoid rock series using multicationic parameters. Chemical Geology 48, 43-55.

Botelho, N. F. 1992. Les ensembles subalcalins a peralumineux mineralisés en Sn et In de la Sous Province Paranã, État de Goiás, Brésil. École Nationale Superieure des Mines de Saint Etienne, Paris, Tese de Doutorado.

Botelho, N. F. ; Moura, M.A. Granite-Ore Deposit Relatioships In Central Brazil. Journal of South American Earth Sciences, Inglaterra, v. 11, n.5, p. 427-438, 1998.

Botelho, N. F. ; Moura, Márcia Abrahão ; Alvarenga, C. J. S. ; Dantas, Elton Luiz ; Dardenne, M. A. ; Campos, J. E. G. ; Menezes, P. R. ; Pereira, A. B. Granitogênese peraluminosa transamazônica no embasamento da Faixa Brasília e seu significado tectônico. In: XLI Congresso Brasileiro de Geologia, 2002, João Pessoa.. Anais. Recife,: Sociedade Brasileira de Geologia - Núcleo Nordeste, 2002. v. 1. p. 436-436.

Botelho, N.F.; Fuck, R.A.; Dantas, E.L.; Laux, J.H.; Junges, S.L. 2006. The Paleoproterozoic peraluminous Aurumina granite suite, Goiás and Tocantins, Brazil: geological, whole rock geochemistry and U-Pb and Sm-Nd isotopic constraints. In: Alkmin, F.F. \& Noce, C.M. The Paleoproterozoic record of the São Francisco Craton, Ouro Preto, Brasil, Field Guide and Abstracts, pp. 92

Botelho, N. F., Bilial, E., Moutte, J., Fonteilles, M. 1993. Precambrian a-type tin-bearing granites in the Goiás tin province, central Brazil: a review. In: Academia Brasileira de Ciências, Workshop sobre Magnetismo Granítico e Mineralizações Associadas, 1, 1993, Rio de Janeiro. Resumos Expandidos, 5-8. 
Botelho, N.F., Alvarenga, C.J.S., Meneses, P.R., D’el-Rey Silva, L.J.H., 1999. Suite Auru-mina: Uma suíte de granitos paleoproterozóicos, peraluminosos e sin-tectônicosna Faixa Brasília. Simpósio de Geologia do Centro Oeste, vol. 7. SBG, Anais,Brasília, pp. 17.

Bühn, B., Pimentel, M.M., Matteini, M., Dantas, E.L., 2009. High spatial resolutionanalysis of Pb and U isotopes for geochronology by laser ablation multi-collectorinductively coupled plasma mass spectrometry (LAMC-ICP-MS). An. Acad. Bras.Cienc. 81, 1-16.

Carr, M.J.; and Gazel, E. 2006. Evolution of Igpet, a Graphics and Modeling Program for Igneous Petrology. Internal Documentation. 37p.

Chappell B. W. \& White A. J. R. 1974. Two contrasting granite types. Pacific Geology 8, 173-174.

Corrêa, R.S. 2014. Deformação, alteração hidrotermal e mineralização aurífera associados ao Granito Príncipe, Distrito Aurífero de Natividade. Universidade de Brasília, Instituto de Geociências. Dissertação de mestrado em geologia $\mathrm{n}^{\mathrm{o}} 335$.

Cordeiro, P.F.O. Compartimentação geológica e geocronológica dos terrenos do embasamento norte da faixa Brasília. 2014. 155 f., il. Tese (Doutorado em Geologia)—Universidade de Brasília, Brasília, 2014.

Cordeiro, P.F.O., Oliveira, C.G., Della Giustina, M.E.S., Dantas, E.L., Santos, R.V. The Paleoproterozoic Campinorte Arc: Tectonic evolution of a Central Brazil pre-Columbia orogeny. Precambrian Research, v. 251, p. 49-61, 2014.

Costa, J.B.S. 1985. Aspectos litoestruturais e evolução crustal da região centro-norte de Goiás. Centro de Geociências, Universidade Federal do Pará, Belém, Tese de Doutoramento, 210p.

Costa, L. A. M., Portella, A. C. P., Nilson, A. A., Vale, C. R. O., Marchetto, C. L. M., Santos, E. L., Meneguesso, G., Inda, H. A. V., Sterna, L. H., Marchetto, M., Baptista, M. B., Fratin, O., Mosmann, O., Oliveira, T. F., Silva, W. G., 1976. Projeto Leste Tocantins/Oeste do São Francisco. Relatório Final, Rio de Janeiro, DNPM/CPRM/PROSPEC, 200p.

Cox, K. G., Bell, J. D. \& Pankhurst, R. J. (1979). The Interpretation of Igneous Rocks. George Allen \& Unwin.

CPRM, 2006. Projeto Aerogeofísico Tocantins: Relatório final do levantamento e processamento dos dados magnetométricos e gamaespectrométricos.

Cruz, E.L.C.C. 1993. Geologia e mineralizações auríferas do Terreno Granitoide-Greenstone de AlmasDianópolis,Tocantins. Dissertação de Mestrado, Instituto de Geociências, Universidade de Brasília, Brasília, 152 p.

Cruz, E.L.C.C. 2001. A gênese e o contexto tectônico da mina Córrego Paiol: um depósito de ouro hospedado em anfibolito do embasamento da Faixa de Dobramentos Brasília. Tese Doutorado, Instituto de Geociências, Universidade Brasília, Brasília. 183 p.

Cruz, E.L.C.C. \& Kuyumjian R.M. 1993. O embasamento da porção norte da Faixa Brasília na região de AlmasDianópolis (TO) e seu contexto geodinâmico durante o Brasiliano. In: SBG, Simpósio Cráton SãoFrancisco, 2, Anais, p. 302-304.

Cruz, E.L.C.C. \& Kuyumjian R.M. 1996. Chemical characterization of metabasalts and granitoids from the Almas-Dianópolis granite-greenstone terrane, central Brazil. In: SBG, Symposium Archaean Terranes South American Platform, 1, Extended Abstracts, p. 53-54.

Cruz, E.L.C.C. \& Kuyumjiam R.M. 1998. The geology and tectonic evolution of the Tocantins granitegreenstone terrane: Almas-Dianópolis region, Tocantins State, Central Brasil. Rev. Bras. Geoc., 28(2):173-182.

Cruz, E.L.C.C. \& Kuyumjiam R.M. 1999. Mineralizações auríferas fi loneanas do terreno granito-greenstone do Tocantins. Rev. Bras. Geoc., 29(3):291-298. 
Cruz, E.L.C.C. \& Kuyumjian R.M. 2006. Geochronology, isotopic signature and metallogenetic model for the Córrego Paiol gold deposit, Tocantins state, central Brazil. Rev. Bras. Geoc., 36(1-Suplemento):152-156.

Cruz, E.L.C.C. Kuyumjian R.M. \& Boaventura G.R. 2003. Low-K calc-alkaline granitic series of southeastern Tocantins State: Chemical evidence for two sources for the granite-gneissic complexes in the Paleoproterozoic Almas-Dianópolis Terrane. Rev. Bras. Geoc.,33(2):125-136.

Correia Filho, F. C. L.; Sa, A. M. 1980. Projeto Natividade. Goiania, DNPM/CPRM. 6 vol.

Czamanske, G.K. and Mihalik, P., 1972. Oxidation during magmatic differentiation, Finnmarka complex, Oslo area, Norway: Part I, The opaque oxides. Jour. PetroJ., 13: 493-509.

Dardenne, M.A., 2000. The Brasília fold belt. In: Cordani, U.G., Milani, E.J., ThomazFilho, A., Campos, D.A. (Eds.), Tectonic Evolution of South America. Rio de Janeiro,31st International Geological Congress. , pp. 231263.

Dardenne, M.A., Saboia, A.M. Litoestratigrafia Do Grupo Natividade Na Região De Natividade-Pindorama, Sudeste Do Estado De Tocantins. In: Lúcia Travassos da Rosa-Costa; Evandro Luiz Klein; Eduardo Paim Viglio. (Org.). Contribuições à geologia da Amazônia. 1ed.Belém: , 2007, v. 5, p. 1-185.

Dardenne, M.A., Della Giustina M.E.S., Sabóia A.M., Bogossian J. 2009. Datação geocronológica U-Pb da sequência vulcânica de Almas, Tocantins. In: SBG, Simp. Geol. Centro-Oeste, 11, Anais, 1 CD-Rom.

Della Giustina, M.E.S. 2007. Geologia e Geocronologia da Seqüência Vulcano-sedimentar Campinorte e do Complexo Uruaçu, Província Tocantins. Universidade de Brasília, Instituto de Geociências, Dissertação de Mestrado $n^{\circ} 234$.

Della Giustina, M.E.S., Oliveira, C.G., Pimentel, M.M., Melo, L.V., Fuck, R.A., Dantas, E.L., Buhn, B. U-Pb and Sm-nd constraints on the nature and evolution of Paleoproterozoic juvenile crust in the Tocantins Province, Central Brazil. Geological Society Special Publication, v. 323, p. 255-269, 2009.

Della Giustina, M.E.S., Oliveira, C.G., Pimentel, M.M., Buhn, B. U-Pb LAM-ICPMS Geochronological data and Sm-Nd isotopic Neoproterozoic magmatism and high-grade metamorphism in the Goiás Massif: New LAMICPMS U-Pb and Sm-Nd data and implications for the collisional history of the Brasília Belt. Precambrian Research, v. 172, p. 67-79, 2009.

Evans, D.A.D., Mitchell, R.N., 2011. Assembly and breakup of the core of Paleoproterozoic-Mesoproterozoic supercontinent Nuna. Geology 39, 443-446.

Faure, G. and Mensing, T.M. (2005). Isotopes: Principles and Applications. John Wiley \& Sons. 897 pp.

Fava, N. Introdução à Microssonda Eletrõnica. Instituto de Geociências, Universidade de Brasília. 13 p.

Ferreira Filho, C.F. 1994. The Niquelândia Mafic-Ultramafic Layered Intrusion, North-Goiás, Brazil: Petrology, Age and Potencial for PGE Deposits. Department of Geology, University of Toronto, Toronto, PhD thesis, 270p.

Fortes, P.T.F.O., Pimentel, M.M., Santos, R.V., Junges, S.L. Sm-Nd studies at Mina III gold deposit, Crixas greenstone belt, central Brazil: implications for the depositional age of the upper metasedimentary rocks and associated Au mineralization. Journal of South American Earth Sciences, Netherlands, v. 16, n.6, p. 503-512, 2003.

Fuck, R.A., Pimentel, M.M., D'el-Rey Silva, L.J.H. 1994 - Compartimentação tectônica na porção ocidental da Província Tocantins. In. $38^{\circ}$ Congresso Brasileiro de Geologia, Bol. Res. Expandidos, V.1:p. 215-216.

Fuck, R.A., Dantas, E.L., Pimentel, M.M., 2001. Nd isotopes U-Pb single grains and SHRIMP zircon ages from basement rocks of the Tocantins Province. Symposium of Isotopes Geology. Pucón, Chile. 311-313.

Fuck, R.A., Dantas, E.L., Pimentel, M.M., Botelho, N.F., Junges, S.L., Hollanda, M.H.B.M., Moraes, R. Crosta continental paleoproterozóica no embasamento da porção norte da Faixa Brasília: novos dados Sm-Nd e U-Pb. 
In: 41 Congresso Brasileiro De Geologia, 2002, João Pessoa. Anais. Recife: Sociedade Brasileira de Geologia, 2002. v. 1. p. 308-308.

Fuck, R.A. Pimentel, M.M. Soares J.E., Dantas, E. L. 2005. Compartimentação da Faixa Brasília. In: Simpósio de Geologia do Centro-Oeste, 9, 2005, Goiânia. Anais. p.26-27.

Fuck, R.A., Dantas, E.L., Pimentel, M.M., Botelho, N.F., Armstrong, R., Laux, J.H., Junges, S.L., Soares, J.E., Praxedes, I.F. Paleoproterozoic crust-formation and reworking events in the Tocantins Province, Central Brazil: a contribution for Atlantica supercontinent reconstruction. Precambrian Research, v. 244, p. 53-74, 2014.

Gioia, S.M.C.L. \& Pimentel, M.M. 2000. The Sm-Nd isotopic method in the Geochronology Laboratory of the University of Brasília. Anais da Academia Brasileira de Ciências, 72 (2), 219-245.

Goldschmidt, V.M. 1954. Geochemistry. Clarendon Press, Oxford. 730 pp.

Gorayeb, P.S.S. 1988. O Pré-Cambriano na Região de Natividade - GO. Revista Brasileira de Geociências 18(4): 391-397.

Gorayeb P.S.S., Moura C.A.V., Arcanjo S.H.S. 2000. Granitogenesis events in the Porto Nacional - Palmas Paraiso do Tocantins region, Tocantins Province, Brazil. In: Internat. Geol. Congr. 31., CD ROM.

Gorayeb, P.S.S., Moura, C.A.V., Barros, G.R. Pb-Pb zircon ages of the Porto Nacional High-Grade Metamorphic Terrain, Northern portion of the Goiás Massif, Central-Brazil. Revista Brasileira de Geociências, São Paulo, v. 30, n.1, p. 215-224, 2000.

Green, T. H.; Pearson, N. J. 1987. An experimental study of $\mathrm{Nb}$ and Ta partitioning between Tirich minerals and silicate liquids at high pressure and temperature; Geochim.Cosmochim. Acta 51 55-62.

Horstwood, M.S.A., Foster, G.L., Parrish, R.R., Noble, S.R., Nowell, G.M., 2003. Common-Pb corrected in situ $\mathrm{U}-\mathrm{Pb}$ accessory mineral geochronology by LA-MC-ICP-MS. Journal of Analytical Atomic Spectrometry 18 (8), $837-846$.

Irvine, T. N. \& Baragar, W. R. A. (1971). A guide to the chemical classification of the common volcanic rocks. Canadian Journal of Earth Sciences 8, 523-548.

Ishihara, S., 1977. The magnetite-series and ilmenite-series granitic rocks. Mining Ceol., 27: 293-305.

Jackson, S.E., Pearson, N.J., Griffin, W.L., Belousova, E.A. 2004. The application of laser blationinductively coupled plasma-mass spectrometry to in situ U-Pb zircon geochronology. Chemical Geology, 211, 47-69.

Jost, H., Fuck, R.A., Dantas, E.L., Rancan, C.C., Rezende, D.B., Santos, E., Portela, J.F., Mattos, L., Chiarini, M.F.N., Oliveira, R.C., Silva, S.E. Geologia e geocronologia do Complexo Uvá, bloco arqueano de Goiás. Revista Brasileira de Geociências, v. 35, p. 559-572, 2005.

Jost, H., Dussin, I. A.; Chemale Jr, F., Tassinari, C.C.G., Junges, S.L. U-Pb and Sm-Nd constraints for the Paleoproterozoic age of the metasedimentary sequences of the Goiás Archean greenstone belts. In: VI South American Symposium on Isotope Geology, 2008, San Carlos de Bariloche. Proceedings of the VI South American Symposium on Isotope Geology, 2008. p. 1-4.

Jost, H., Chemale Jr., F., Fuck, R.A., Dussin, I.A., 2013. Uvá Complex, the oldest orthogneiss of the ArcheanPaleoproterozoic terrane of central Brazil. Journal of South American Earth Sciences 47, 201-212.

Kuyumjian, R.M. 1994. A seqüência Mara Rosa na região de Chapada, Goiás. In, SBG, Núcleo Brasília, Bol. Informativo, 17 (1-2): 34-38.

Kuyumjian, R.M. \& Araújo Filho J.O. 2005. Depósitos e ocorrências de ouro no terreno arqueanopaleoproterozóico de Almas-Dianópolis (TO): evidências da importância metalogenética do evento Brasiliano. Rev. Bras. Geoc., 35(4):611-614. 
Kuyumjian, R.M. Cruz, E.L.C.C. Araújo Filho, J.O. Moura, M.A. Guimarães, E.M. Pereira, K.M.S. 2012. Geologia e ocorrências de ouro do Terreno Granito-Greenstone do Tocantins, TO: síntese do conhecimento e parâmetros para exploração mineral. In: Ver. Bras. Geoc., 42(1): 213-218.

Kwitko, R., Masotti F., Baars F.J., Abreu F.R., Bella V.C.M., Ferrari A.J.D., Fuck R.F., Gomes R.P., Ribeiro E., Tallarico F., Vial D.S., Viana F.H. 1995. Petrografi a, alteração hidrotermal e mineralização aurífera da jazida do Córrego Paiol - Almas (TO). In: SBG, Congr. Bras. Geoquímica, 5, Anais, 1 CD-Rom.

Lacerda Filho J.V., Marques V.J., Scislewski G., Jorge L., Justo E.C., Oliveira C.C. 1991. Projeto Geologia da Região Centro Oeste, Folha Caraíba. Goiânia, CPRM, 145p.

Lalonde, A.E., Bernard, P., 1993. Composition and Color of Biotite from Granites: Two Useful Properties in the Characterization of Plutonic Suites from the Hepburn Internal Zone of Wopmay Orogen, Northwest Territories. Canadian Mineralogists,31: 203-217.

Laux, J.H.; Pimentel, M.M.; Dantas, E.L.; Armstrong, R.; Junges, S.L. 2005. Two Neoproterozoic custal accretion events in the Brasília Belt, central Brazil. Journal of South American Earth Sciences, 18: 183-198.

Le Bas, M. J., Le Maitre, R. W., Streckeisen, A. \& Zanettin, B. (1986). A chemical classification of volcanic rocks based on the total alkali-silica diagram. Journal of Petrology 27, 745-750.

Lima, E.A.M. 2014. Petrografia, química mineral e geocronologia U-Pb La-Icpms de minerais acessórios da localidade de Príncipe, Bloco Natividade-Cavalcante, Tocantins. Universidade de Brasília, Instituto de Geociências, Dissertação de Mestrado em Geologia.

Ludwig, K.R., 2008, Manual for Isoplot 3.7: Berkeley Geochronology Center, Special Publication No. 4. rev. August 26, 2008, 77 pp.

Mantovani, M.S.M. \& Brito Neves, B.B. 2005. The Paranapanema lithospheric block: its importance for Proterozoic (Rodinia, Gondwana) supercontinent theories. Gondwana Research, 8, 303-315.

Marangoni, Y.R., Assumpção, M., Fernandes, E.P. 1995. Gravimetria em Goiás, Brasil. Revista Brasileira de Geofísica 13 (3), 205-219.

Marques, G.C., 2009. Geologia dos Grupos Araí e Serra da Mesa e seu embasamento no sul do Tocantins. Universidade de Brasília, Instituto de Geociências, Dissertação de Mestrado em Geologia, no 261.

Martins-Neto, M.A. 2009. Sequence stratigraphic framework of Proterozoic successions in eastern Brazil. Marine and Petroleum Geology 26, 163-176.

Miller, C.F., Stoddard, E.F., 1981. The role of manganese in the paragenesis of magmatic garnet: an example from the Old Woman Piute Range, California. J. Geol. 89, 233-246.

Miller, C.F., Stoddard, E.F., Bradfish, L.J., Dollase, W.A., 1981. Composition of plutonic muscovite: genetic implications. Can. Mineral. 19, 25-34.

Moura, C.C.V. \& Gaudette, H.E. 1994. Geochemistry of the basement orthogneisses of the Araguaia belt, Tocantins-Brazil. In: SBG, Congresso Brasileiro de Geologia, 38, Camboriú, Boletim de resumos Expandidos, 1: $240-241$

Moraes, R., Fuck, A.R., Pimentel, M.M., Gioia, S.M.C.L., Hollanda, M.H.B.M., Armstrong, R., 2006. The bimodal rift-related volcanosedimentary sequence in Central Brazil: Mesoproterozoic extention and Neoproterozoic metamorphism. Journal of South American Earth Sciences 20, 287-301.

Nachit, H., Abderrahmane, I., Abia, E.H., Ben Ohoud, M. 2005. Discrimination between primary magmatic biotites, reequilibrated biotites and neoformed biotites. C. R. Geoscience, 337,pp. 1415-1420.

Nockolds, S. R. \& Allen, R. 1953. The geochemistry of some igneous rock series. Geochim \& Cosmochim Acta, 4, 105-42. 
O'Connor, J. T. (1965). A classification for quartz-rich igneous rocks based on feldspar ratios. In: US Geological Survey Professional Paper B525. USGS, 79-84.

Oliveira, C.G.; Oliveira, F. B.; Dantas, E.L.; Fuck, R.A.; Della Giustina, M.E.S. 2006. Programa Geologia do Brasil - Folha Campinorte. FUB/CPRM, Brasília, 124 pp.

Oliveira, C.G. 2012. Projeto Natividade. Instituto de Geociências. Universidade de Brasília.

Padilha, J. L. 1984. Prospecção de ouro na região nordeste de Goiás. Projeto Pindorama. DOCEGEO. In: SBG, Encontro Regional do Ouro de Goiás, 1, Goiânia. Anais, 78-95.

Pearce, J. A., Harris, N. W. \& Tindle, A. G. (1984). Trace element discrimination diagrams for the tectonic interpretation of granitic rocks. Journal of Petrology 25, 956-983.

Peccerillo, A. \& Taylor, S. R. (1976). Geochemistry of Eocene calc-alkaline volcanic rocks from the Kastamonu area, Northern Turkey. Contributions to Mineralogy and Petrology 58, 63-81.

Pereira, R.S., Fuck, R.A., 2005. Archean Nucleii and the distribution of kimberlite and related rocks in the São Francisco Craton, Brazil. Revista Brasileira de Geociências 35, 93-104.

Pimentel, M.M., Fuck,R.A. Neoproterozoic crustal accretion in central Brazil. Geology, v. 20, n.4, p. 375-379, 1992.

Pimentel, M.M.; Fuck, R.A.; Botelho, N.F. 1999. Granites ad the geodynamic history of the Neoproterozoic Brasília Belt, Central Brazil. Lithos, 46 (3): 463-483.

Pimentel, M.M., Fuck,R.A., Fischel,D.P. Estudo isotópico Sm-Nd regional da porção central da Faixa Brasília: implicações para idade e origem dos granulitos do Complexo Anápolis-Itauçu e sedimentos do Grupo Araxá. Revista Brasileira de Geociências, v. 29, n.2, p. 271-276, 1999.

Pimentel, M. M., Fuck,R.A., Jost, H., Ferreira Filho, C.F., Araujo, S. The basement of the Brasília Fold Belt and the Goiás Magmatic Arc. In: Cordani ,U.G.; Milani,E.J; Thomaz Filho, A; Campos,D.A.. (Org.). The Tectonic Evolution of South America. Rio de Janeiro: 31. IGC, 2000, p. 195-229.

Pimentel, M.M., Ferreira Filho, C.F., Armstrong, R. A. 2004. SHRIMP U-Pb and Sm-Nd ages of the Niquelândia layered complex: Meso- $(1,25 \mathrm{Ga})$ and Neoproterozoic $(0,79 \mathrm{Ga})$ extensional events in central Brazil. Precambrian Research, 132: 133-153.

Pimentel, M.M., Ferreira Filho, C.F., Armele, A. 2006. Neoproterozoic age of the Niquelândia Complex, central Brazil: further ID-TIMS and Sm-Nd isotopic evidence. Journal of South American Earth Science, 21: 228-238.

Pimentel, M.M., Rodrigues, J.B., Della Giustina, M.E.S., Junges, S.L., Matteini, M. The tectonic evolution of the Neoproterozoic Brasília Belt, Central Brazil, based on Shrimp and La-Icpms U-Pb sedimentary provenance data: a review. Journal of South American Earth Sciences, v. 31, p. 345-357, 2011.

Piuzana, D., Pimentel, M.M., Fuck, R. A., Armstrong, R.A. U-Pb SHRIMP and Sm-Nd geochronology of the Silvânia Volcanics and Jurubatuba Granite: juvenile Paleoproterozoic crust in the basement of the Neoproterozoic Brasília Belt, Goiás, central Brazil. Anais da Academia Brasileira de Ciências (Impresso), Rio de Janeiro, v. 73, n.3, p. 445-460, 2001

Piuzana, D. 2002. Contribuição à Evolução Crustal da Porção Central da Faixa Brasília: Estudos Isotópicos no Complexo Anápolis-Itauçu, Grupo Araxá, Sequência Vulcano Sedimentar de Silvânia e Granitóides Associados. Tese de Doutorado n55. Instituto de Geociências. UnB. Brasília.

Queiroz, J. P. C., 2001. Geologia e mineralização aurífera da área de Chapada-TO. 118 f. Dissertação (Mestrado) - Curso de Pós-Graduação em Geologia e Geoquímica, Centro de Geociências, Universidade Federal do Pará, Belém. 
Resende, M.G., Jost, H., Moreira, B.E., Teixeira, A.A. Proveniência e idade Sm-Nd das rochas siliciclásticas arqueanas dos greenstone belts de Faina e Santa Rita, Goiás. Revista Brasileira de Geociências, São Paulo, v. 29, n.3, p. 281-290, 1999.

Rogers, J.J.W., Santosh, M., 2002. Configuration of Columbia, a Mesoproterozoic supercontinent. Gondwana Research 5, 5-22.

Saboia, A.M., 2009. Litoestratigrafia do Grupo Natividade e vulcanismo em Monte do Carmo, Estado de Tocantins. Universidade de Brasília, Insituto de Geociências, Dissertação de Mestrado em Geolgia, nº 263.

Shand, S. J. (1943). Eruptive Rocks. Their Genesis, Composition, Classification, and Their Relation to OreDeposits with a Chapter on Meteorite. New York: John Wiley \& Sons.

Simonetti, A., Heaman, L.M., Chacko, T., Banerjee, N.R. 2006. In situ petrographic thin section U-Pb dating of zircon, monazite, and titanite using laser ablation-MC-ICPMS. International Journal of Mass Spectrometry 253 (1-2), 87-97.

Streckeisen, A.L., 1976. To each plutonic rock its proper name. Earth Sci. Rev. 12, 1-33.

Sun, S.S., McDonough, W.F., 1989. Chemical and isotopic systematics of oceanic basalts: implications formantle compositions and processes. In: Saunders, A.D., Norry, M.J. (Eds.), Magmatism in Ocean Basins, vol. 42. Geological Society of London, pp. 313-345, Special Pub.

Tassinari, C.C.G., Jost, H., Santos, J., Nutman, A., Bennell, M.R. Pb and Nd isotope signatures and SHRIMP U$\mathrm{Pb}$ geochronological evidence of paleoproterozoic age for Mina III gold mineralizations, Crixás District, Central Brasil. In: 5h South American Symposium on Isotope Geology, 2006, Punta Del Este. Short Papers Volume, 2006. p. 527-529.

Taylor SR, McLennan SM (1981) The composition and evolution of the continental crust: rare earth element evidence from sedimentary rocks. Oxford: Blackwell. 312 pp.

Trindade, C.R. 2014. Espessura crustal e razão de Poisson do Brasil Central: uma aproximação por função do receptor. Universidade de Brasília, Insituto de Geociências, Dissertação de Mestrado em Geociências Aplicadas, $n^{\circ} 70$.

Unrug, R., 1996. The assembly of Gondwanaland. Episodes 19, 11-20.

Valeriano, C.M., Pimentel, M.M., Heilbron, M., Almeida, J.C.H., Trouw, R.A.J. 2008. Tectonic evolution of the Brasília Belt, Central Brazil, and early assembly of Gondwana. In: Pankhurst, R.J., Trouw, R.A.J., Brito Neves, B.B., De Wit, M.J. (Eds.) West Gondwana: Pre-Cenozoic Correlations Across the South Atlantic Region. Geological Society, London, Special Publications, 294, 197-210.

Wetherill, G.W. 1956. Discordant uranium-lead ages: 1. Transactions of the American Geophysical Union, 37 : 320-326.

Zhao, G., Cawood, P.A., Wilde, S.A., Sun, M. 2002. Review of global 2.1-1.8 Ga orogens: implications for a pre-Rodinia supercontinent. Earth-Science Reviews, 59: 125-162.

Zhao, G., Sun, M., Wilde, S.A., Li, S. 2004. A Paleo-Mesoproterozoic supercontinent: assembly, growth and breakup. Earth-Science Reviews, 67: 91-123.

Zhao, G., Sun, M., Wilde, S.A., Li, S., Zhang, J., 2006. Some key issues in reconstructingProterozoic continents. Journal of Asian Earth Sciences 28, 3-19. 